
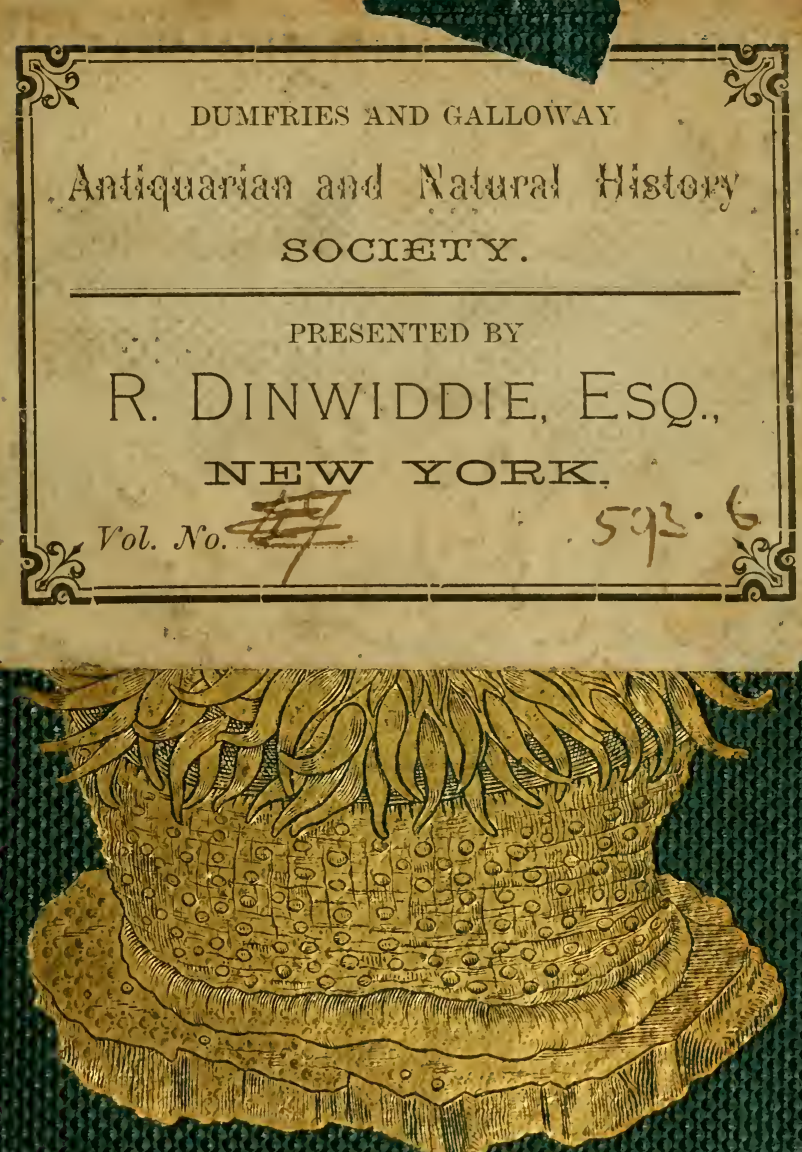
whidondwastey Faf/t? 
Thome f, M. Schat 



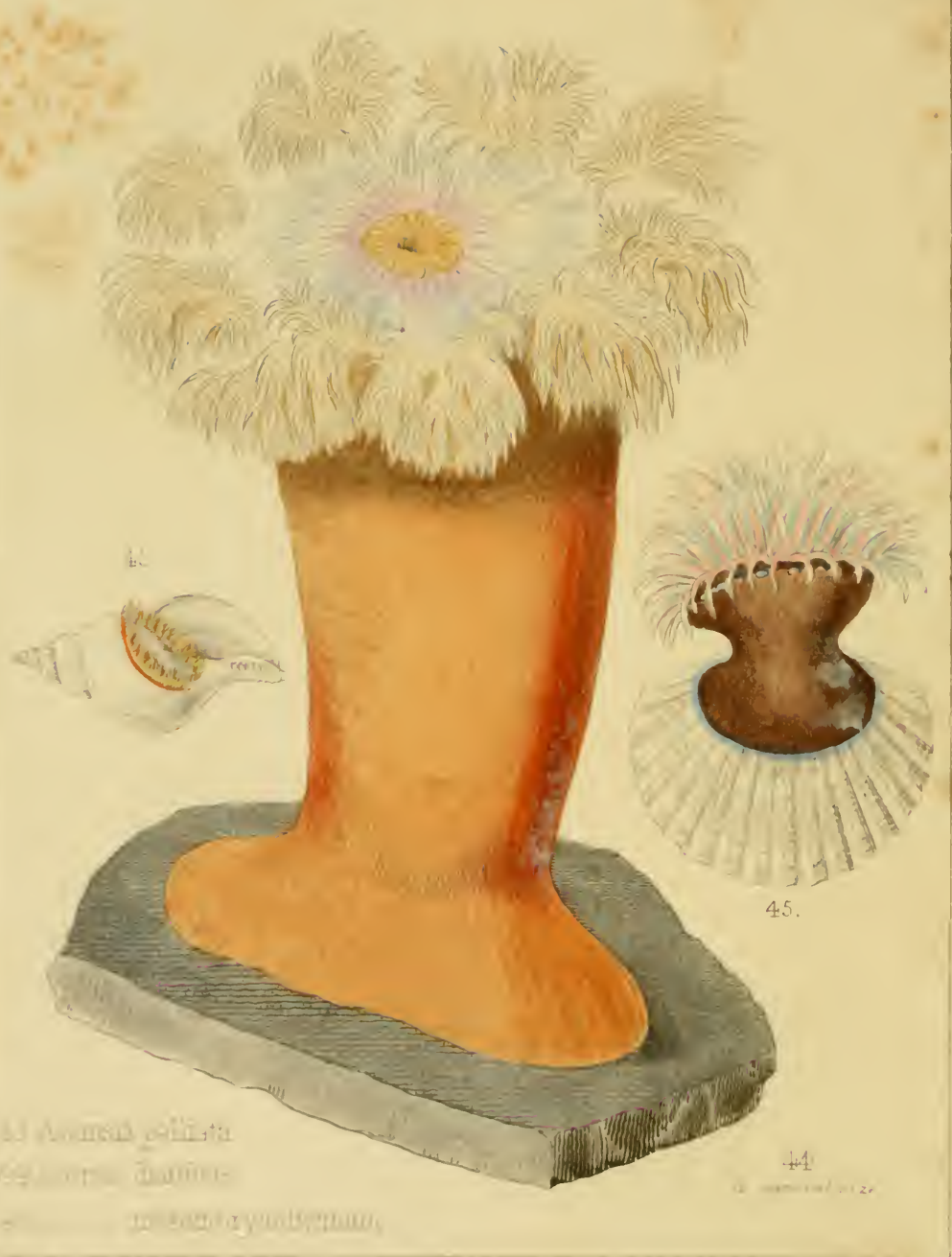




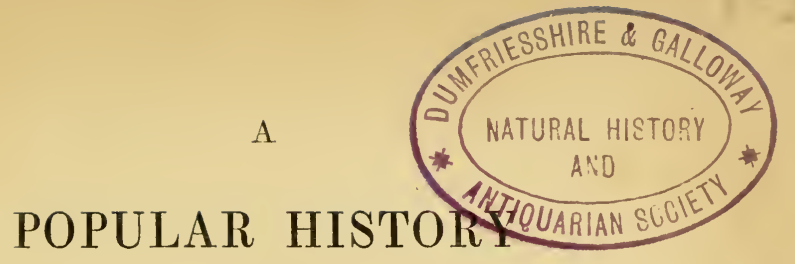

OF

\title{
BRITISH ZOOPHYTES,
}

OR

\section{CORALLINES.}

\author{
BY THE \\ Rev. D. LANDSBOROUGH, D.D., A.L.S., etc., \\ $\triangle U T H O R$ OF \\ 'A POPULAR HISTORY OF BRITISH SEAWEEDS,' AND OF \\ 'EXCURSIONS TO THE ISLE OF ARRAN.'
}

LONDON :

REEVE AND CO., HENRIETTA STREET, COVENT GARDEN.

1852. 


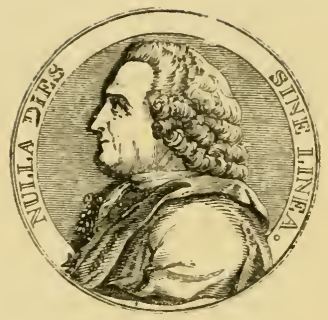

JOHX EDWARD TAYLOR, PRINTER, LITILE QUEEN STREET, LIXCOLN'S INN FIELDS. 
TO

\section{JOHN FLEMING, D.D.,}

PROFESSOR OF NATURAL SCIENCE, NEW COLLEGE, EDINBURGH,

AND

GEORGE JOHNSTON, M.D., LL.D.,

FELLOW OF THE ROYAL COLLEGE OF SURGEONS OF EDINBURGH,

This 蹗ittle Yolume

IS

WITH GREAT ESTEEM AND AFFECTION

DEDICATED

BY THEIR GRATEFUL FRIEND, 



\section{PREFA CE.}

Were 1 to say, "this is a very interesting little book," many would conclude that I was nearly allied to a wellknown bird, whose mouth is so often filled with the praise of its own beauty. And yet I might say so without the slightest vanity; for I shine by borrowed light, and for nearly all that is interesting in the book I am indebted to my talented scientific friends and precursors. I have been like the bee-not making, but gathering honey. Like the bee, I have formed the cells, and had I been able to equal her in skill, I might well have been pleased with my workmanship. But though inferior in skill, I have not, during the progress of the work, been inferior to her in 
industry. Having the prospect of leaving home for a few - months, I wished to have it in the hands of the printer before the end of March, and therefore during the winter, while I was all day, and every day, occupied with my professional duties, in the dark morning hours, and in the darker hours of night, when even in summer the bee would have been sound asleep, I was "aye write-writing;" so that by dint of perseverance in working double tides, ere March was over my labours had come to a close.

Though carried on both late and early, the labours were far from being unpleasant. Admiring the beautiful creatures and their exquisite workmanship, a person is almost unavoidably led to think of Him who works in them, by them, for them,-and to say, If he cares for these almost invisible entities, which cannot, except by the happiness they exhibit, acknowledge His kindness, how much more will He care for us, if we seek to know Him, and put our trust in Him as our reconciled God!

1 was cheered on also by the aid so readily given to me by many kind-hearted friends, to whom I am under great 
obligations. To my much-esteemed friend, Dr. John Fleming, Professor of Natural Science in the New College of Edimburgh, I owe much, not only for what instruction I have derived from his well-known publications, but for information which $I$ have received from his kind correspondenee, without which I probably should never have entered on this department of study. To Dr. George Johnston, another much-valued friend, I need not say that I am specially indebted, for almost every page of my book proclaims my obligations; and I hope it may prove a stepping-stone to his admirable volumes. To George Busk, Esq., of Greenwich, I return my grateful thanks, for not only giving me information and drawings, but for kindly superintending the arrangement of the illustrations, and thus contributing much to the usefulness of the work. To the Rev. Thomas Hincks, of Exeter, I am truly thankful for favouring me with a list of Devonshire Zoophytes, with specimens of the rarest of them, and for kindly permitting me to use his articles in the 'Annals of Natural History' respecting interesting Zoophytes which he has added to the British 
Fauna. I return my kind thanks also to Richard Q. Couch, Esq., for the benefit I have derived from his 'Cornish Fauna,' and for other publications he kindly sent to me. For aid given me by the loan of books, by furnishing me with specimens, and in various other ways, I have been much indebted to Mr. Ralfs, of Penzance; to Mr. Tudor, of Bootle; to Mr. Bean, of Scarborough ; to Mr. Tumanowicz, of Hastings; to Mr. Wigham, of Norwich; to Dr. R. Th. Greville, of Edinburgh ; to Dr. Scouler, of Dublin; to Mr. W. Gourlie, Mr. W. Keddie, and Mr. R. Gray, of Glasgow ; as also to Major Alexander Martin, of Ardrossan; and to all of them I now return my grateful thanks.

With still higher pleasure I acknowledge my obligations to many scientific ladies. Mrs. Griffiths, ever ready to instruct and oblige, favoured me with many specimens, when I had the pleasure of visiting her at Torquay. Many specimens I received from Miss Cutler, of Budleigh Salterton; Mrs. Gulson, of Exmouth; and Miss S. Beever, of Coniston. Many thanks are due to Mrs. Spode, of Armitage Park, for a tasteful drawing of a beautiful Zetland Zoophyte, Retepora 
Beaniana, kindly lent for that purpose by Mr. Barlee. I am exceedingly indebted to Mrs. Gatty, of Ecclesfield Vicarage, for rare specimens, for much information, and for all the beautiful drawings in Plate XVIII., except the exquisite figure of Lepralia Gattyce by Dr. R. Th. Greville.

I am glad that some of our Scottish scientific ladies have kindly come to my aid. I return Lady Emma Campbell, of Argyle, my respectful thanks for some interesting Zoophytes sent to me from Lochfine, and from the island of Islay. To Lady Keith Murray, also, I am greatly indebted for several rare Zoophytes, and for a list of those collected by her on the east coast of Scotland, near Stonehaven. To Miss C. Allardyce, of Cromarty, I return my grateful acknowledgments for some of the rarer Zoophytes collected on that classic coast; and to Mrs. Blair, of Blair, I render my best thanks for the aid she has kindly given me.

With such a phalanx of able auxiliaries, I certainly ought to have produced a book that was readable. I have done what I could. The enterprising Publishers and the talented Artist have nobly done their part, and if the book 
should prove popular, to them much of the meed of praise is due. I have written chiefly for the young; and while I have wished to smooth for them the entrance into this delightful field of Natural Science, I have sought to give a good moral tone to the book, that they may look "through Nature up to Nature's God," remembering that the God of Nature is also the God of Grace. He las given us the "book of books" to make us wise unto salvation; but $\mathrm{He}$ has given us also the book of Nature, making it accessible to all; and in many a delightful page of it does He plainly say, "Come, see the works of my hand, so full of wonders, and so well-fitted to show forth my praise."

"Every leaf in every nook, Every wave in every brook, Every Polype from its cell In sea-rock pool or crystal well, Chanting with a solemn roice, Minds us of our better choice."

KEBLF.

Gibraltar, June 22, 1852. 


\section{LIST OF PLATES.}

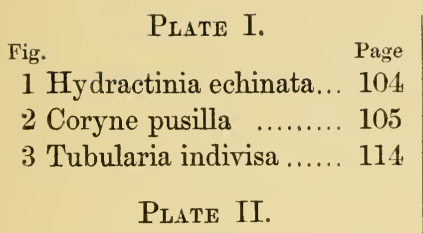

4. Tubularia larynx ..... 117

5 Eudendrium rameum .. 108

6 Sertularia tamarisca ... 129

\section{Plate III.}

7 Halecium halecinum ... 121

$8-$ Beanii.............. 121

9 - muricatum.

122

\section{Plate IV.}

10 Sertularia polyzonias... 123

$11-$ rugosa............. 124

12 - rosacea .......... 125

$13-$ pumila .......... 1.25

$$
\text { Plate } V \text {. }
$$

14. Sertularia abietina ...... 130

15 - argentea........... 135

16 - operculata ........ 133

17 _filicula
Fig. Plate VI. Page

18 Thuiaria thuia ........ 139

$19-$ articulata ........ 139

Plate VII.

20 Antennularia antennina 141 21 ramosa .......... 142

Plate VIII.

22 Plumularia falcata..... 144

23 - cristata ........... 145

$24-$ pennatula ........ 147

25 - pinnata .......... 147

Plate IX.

26 Plumularia setacea ... 150

27 Catharina ........ 151

28 - myriophyllum ... 152

$29-$ frutescens ........ 156

Plate X.

30 Laomedea dichotoma... 158

31 - geniculata ........ 160

32 - gelatinosa ........ 161

33 Campanul. verticillata 167

Plate XI.

132 34 Laomedea obliqua ..... 162 
Fig.

35 Campanularia dumosa . 168 36 — rolubilis ........... 163

37 - syringa ........... 166

38 - integra ........... 165 Plate XII.

$39 \mathrm{Hy}$ dra viridis ........... 188

40) Virgularia mirabilis ... 197

41 Pennatula phosphorea 194

42 Gorgonia rerrucosa ... 205 Plate XIII.

1.3 Adamsia palliata 228

41. Actinia Dianthus ..... 254

1.5 - Mesembryanth. .. 212 Plate XIV.

46 Actinia crassicornis ... 251

47 Iluanthos Scoticus..... 260

48 Lucernaria fascicularis 261

19 - auricula .......... 262

Plate XV.

50 Tubulipora flabellaris... 274.

51 Crisidia cornuta ........ 284

52 Crisia eburnea........... 281

53 Eucratea chelata........ 286

51. Hippothoa catenularia 292

5.5 - divaricata ....... 293

$$
\text { Plate TVI. }
$$

56 Anguinaria spathulata. 287 57 - truncata ........... 288

Fig. Page

58 Gemellaria lorieulata... 296

59 Gemicellaria Bursaria . 297

60 Alecto major .......... 279

Plate XVII.

61 Cellipora ramulosa..... 300

62 Cellularia ciliata........ 337

63 Flustra foliacea ........ 3416

64 - truncata ........... 348

65 Membranipora pilosa... 328

Plate XVIII.

66 Lepralia ciliata ........ 323

67 - pediostoma......... 316

68 - annulata........... 313

69 — granifera ....... 309

$70-$ melolontha........ 319

$71-$ Gattyæ .......... 326

Plate XIX.

72 Cellularia avicularia ... 341

73 Retepora Beaniana.. ... 361

74 Salicorn. farciminoides 362

75 Beania mirabilis........ 369

76 Serialaria lendigera ... 367

\section{Plate XX.}

77 Vesicularia spinosa .. 368

78 Valkeria Cuscuta ..... 370

79 Farrella producta ..... 374.

so Mimosella gracilis ..... 376 


\section{POPULAR}

\section{HISTORY OF BRITISH ZOOPHYTES.}

\section{CHAPTER I.}

\section{INTRODUCTORY.}

"The treasures of Nature are inexhaustible. Here is employment enough for the vastest parts, the most indefatigable industries, the happiest opportunities, the most prolix and undisturbed vacancies; and for our encouragement in this study observe what the Psalmist saith: "The works of the Lord are great, sought out of all them that have pleasure therein." "-Ray.

"How sweet to muse upon the skill display'd (Infinite skill!) in all that He hath made, To trace in Nature's most minute design The signature and stamp of power divine."-Cowper.

According to a well-known axiom of Linnæus, "stones grow, vegetables grow and live, animals grow, live, and feel." In writing a former little volume on Seaweeds, much as I admired these ocean-flowers, I felt that they wanted one charm: for though in one sense, according to Linnæus, they 
might be said to live, they were not sentient beings,- they did not feel. A true lover of nature, however, treats them with kindliness, as if they enjoyed life. We have known amiable enthusiasts, who, without holding it as a fixed principle, acted as if the plants they admired and loved really had sentient life. The late Mr. James Smith, of Monkwoodgrove in Ayrshire, was a person of this description. They tell that when he was constrained to cut down a tree that was overshadowing other plants in his garden, he blindfolded himself that he might not see the wounds which the axe inflicted. When he was showing the beauties of his greenhouse one day to two ladies, friends of mine, one of them said to him, "Mr. Smith, what is that in the flowerpot? it is very like a nettle." His answer was, "Indeed, ma'am, it is just a nettle, but it grew up sae bonnily, puir thing, that I could not think to pu' it." 'Though we may not go the length of sparing the nettle in our mercy, who would wantonly injure a flower? Were we to see a young lady tearing the petals of a lovely rose, she would immediately appear less loveable in our eyes, for it would prove that she was dead to the charms of one of the most beautiful works of God. She has torm and cast to the ground what the fairest fingers and the greatest human skill could never 
have formed; and whether we look at the green leaves, the mossy calyx, the beautifully arranged crimson petals of the corolla, or are refreshed by its fragrant perfume, sweet as Sabean odours, there must be a lack of taste if we do not admire it, and a want of something better than taste if we do not acknowledge it as a kind gift of God to man. He drove us from Paradise when it was polluted by sin, but he has permitted some of the sweets of Eden to follow us; and by giving us the true Rose of Sharon and Jily of the Valley, he seeks to melt our hard hearts, and to win us back to a heavenly Paradise, where the flowers never wither, and where the sun of glory and blessedness never goes down.

Beautiful as seaweeds are, we felt, as we have said, in studying and describing them, that they were less interesting because they were destitute of sentient life. We are glad that we have now mounted a step higher in the order of nature, and that we are now to treat of creatures that grow, and live, and feel. The name Zoophyte, however, would seem to imply that it is only one remove, or rather, only half-removed from inanimate nature, the Greek words from which the term is derived signifying a living plant. But this name was given to it when its nature was imperfectly understood; and it still retains the name, though it is now 
allowed that there is nothing in its growth similar to the growth of plants. The polype, that is, the animal part, grows, and increases in size like other animals; the polypidom, however, the house or covering of the polypes, though it grows, has notling vegetable in its growth, but is caused to increase in size somewhat in the way that a shell is enlarged to suit the increasing size of its inhabitant.

Were we writing the biographical account of any distinguished person, or the history of any remarkable family, we should be disposed to trace their pedigree as far back as we could, especially if there were anything illustrious in the origin; nor would we fail to mention the existing relatives of the individual, and the various branches of the family, though widely spread throughout foreign lands, provided they reflected honour on the person, or were creditable to the family we had undertaken to describe. The families of which we are about to treat, can, at all events, boast of their antiquity, for they are at least as ancient as the period of the flood. We know of no individuals, however, who liave risen to extraordinary distinction, from low beginnings growing in excellenee, and rising to high renown. There has been no sueh wonderful development. The Sertularia that wave their plumes in the sea in the present day, are 
not in the least more skilful than those that lived immediately after the deluge. But they can boast of kindred who were great before the flood, which have for ever passed away, though their existence is proved by their wonderful remains buried in the rocks in every place of our land. And they can more proudly boast of kindred yet alive in foreign climes, numerous almost as the sand on the seashore, which have already achieved, what human power could never have accomplished; and which with unwearied assiduity are still carrying on works, which the united efforts of myriads of millions of mankind would in vain attempt to effect. It will easily be understood that we are speaking of the coral-forming zoophytes of foreign seas. They have wrought wonders in the deep in ages that are past. According to my ingenious friend Mr. Ritchie's dynamical theory of the formation of the earth, zoophytes and other apulmonic creatures were the only animals that existed in the preadamitic seas, when darkness brooded over the face of the deep, and ere God had yet said, "Let there be light, and there was light;"-that during countless ages they were working the work assigned to them by their Creator, gradually forming the crust of the earth. At whatever period the work was done, most evident is it that 
zoophytes must have greatly abounded in the primitive seas, and that then, as now, their constant employment was to separate the carbonate of lime from the waters, thus forming a habitation for themselves, but at the same time unconsciously raising in the deep what was afterwards to be the residence of men, and what was to furnish materials for constructing the cottages of the poor and the palaces of the rich. Most certain it is that the mountain limestone, which abounds throughout our land, so useful in agriculture, in architecture, and in the manufacture of iron the most use ful of metals, was prepared at the bottom of the sea to answer all these important purposes. In breaking up the limestone found in our quarries there is abundant proof of its marine origin, for the organic remains, in general so plentifully found in it, are evidently those of molluscous creatures, and of zoophytes and other animals known to be denizens of the deep. Tell do I remember the delight I experienced many years ago at finding in a little fertile field in my glebe at Stevenston, to which I had recently given a top-dressing of lime from Hullerhirst, in the same Ayrshire parish, the pretty entire remains of a Cassis, or helmet-shell, similar in some degree to those from foreign lands, which are so often placed as ornaments on our mantel-pieces. Though it had 
passed through the lime-kiln, it still retained not only its form, but also some traces of its original colouring. It was sent to the Natural History Museum of the University of Edinburgh, where, I doubt not, it remains to this day. In the same limestone quarry I have gathered various Producti, Terebratula, Nucula, Spirifers, \&c. Asaphus caudatus has occasionally been found, and a star-fish of the Ophiura family. Encrinites are also there, and at times pretty Flustra-like zoophytes, as fresh on the rock as if their lacy web had been woven yesterday. The richness of this fossil deposit was first discovered by my lamented friend George Gardner, Esq., whose sudden death in Ceylon gave so much grief when he was rising to so great eminence in the scientific world. In one of our muscological expeditions he had separated from us for a little and wandered into the quarry. On returning to us he held up exultingly some Terebratulce and a Trilobite, and to our eager inquiry whether there were any more of them, he replied, "Abundance, they are just hotching." A knowledge of Scotch is necessary to see the force and drollery of this expression. Our polished jambs and chimney mantel-pieces of our native marbles, owe much of their beauty to the remains of more magnificent zoophytes than are now to be found in our 
British seas, showing that, under Providence, they had played no inferior part in the olden times in the preparation of what was to gratify the taste and to contribute to the comfort and happiness of the inhabitants of our land in the present day. But their place in our seas is now occupied by those tinier tribes which we are to attempt to describe; zoophytes, as respectable in size and as indefatigable and efficient as the antique, are even now carrying on their mighty operations in the great Pacific Ocean. Our recent British zoophytes have even now, in the Mediterranean Sea, many kindred tribes, which afford employment to some thousands of active seamen in collecting their beautiful works, as well as scope for the taste and industry of many neat-handed artificers ashore, by forming the coral into toys for children, as well as beautiful ornaments for the gay and affluent. Mediterranean corals constitute an article of commerce, and are diligently sought for by persons who fit out vessels for the purpose. They are generally branched in the form of shrubs, and they are broken off from the rocks to which they adhere by long hooked poles. When a crop of corals has been obtained from a habitat, they who are engaged in the trade do not visit the same place again for about a dozen years, treating the corals as they would the wood of a forest by land. 
After ten or twelve years of repose the branches have become a foot or sixteen inches long, and are again ready for the market. They vary much in price, according to the fineness of their tints and the compactness of their structure,- the finest bringing ten guineas an ounce, and the inferior ones not above a shilling a pound.

These Mediterranean corals hold as it were a middle place betwixt our own tiny zoophytes, and the magnificent corals of the great Pacific Ocean. The rate at which the latter grow or increase in size has not yet been accurately ascertained, though it is a matter which bears on questions of considerable scientific importance. Some say that the reefs on which their operations are carried on do not grow above six inches in a hundred years; others again say that from their own observation they are convinced that they grow a foot in a few years. The truth, it is probable, lies between these statements. The rate of growth, as we have said, of Mediterranean corals, has been ascertained with considerable accuracy-not by scientific naturalists, but by rough sailors, who find it their interest to know how often their coral groves yield a fresh crop. Though the rate of growth of our native zoophytes is in many cases matter of uncertainty, yet as we find some of them a foot in height 
growing on Algre probably not more than two years old, the growth of the zoophyte must be pretty rapid. The growth of Flustra foliacea is often very considerable on Laminarice evidently only a year old. We have seen the silvery web overspreading the frond of a Laminaria several feet in extent, though the plant was not in all likelihood more than two years old. Though the growth, then, of corals in the Pacific may not be so rapid as even the Mediterranean corals, yet from analogy we are disposed to conclude that their growth is by no means so slow as some imagine.

But slow or not slow, as coral reefs and coral islands are chiefly the work of marine artificers which are nearly allied in their nature to our British Zoophytes, which we mean to describe, and as their operations are carried on much in the same manner, we are paving the way for the study of the less, when we turn our attention for a little to the greater. It is like applying the magnifying glass to what is minute when we become better acquainted with the larger sized relatives. And certainly there is scarcely anything in the whole range of Natural History more deserving of our attention, or better fitted to fill us with wonder and admiration, than when we see that the great Creator can, by means 
that might seem to us the feeblest, work out the most astonishing results. Great advantage would redound to us from this study of Natural History, were we more diligently to cultivate the habit of seeing the goodness and wisdom and power of God in the works of his hands. It is not enough that we admire beauty and exquisite workmanship, and astonishing results: we should seek habitually to behold not only the wisdom and power of God in these beautiful works, but the great kindness of our Heavenly Father in evidently caring so much for the happiness of the various creatures he has formed.

Williams, in his 'Missionary Enterprises,' when about to give an account of some of the coral reefs and islands of the South Seas, says:- "The great object for which all knowledge should be sought, and for which it ought to be employed, is to illustrate the wisdom or goodness of the great and beneficent Creator. And if we come to the study of natural phenomena with minds unchilled by scepticism or infidelity, we shall be led to sublime religious contemplations; and whether we examine the little coral insect of the ocean, or gaze upon the gigantic beast of the forest; whether we study the little glow-worm which twinkles upon the bank, or the celestial luminaries performing their appointed 
revolutions in majestic silence amidst the vast expanse of infinity, with an ancient and scientific king we shall be led to exclaim, 'How manifold, O God, are all Thy works; in wisdom hast Thou made them all.'

"In all our prying researches after knowledge, it is necessary that the mind be firmly established upon two great points-the belief in a Divine creative agency, and in the Divine authenticity of the Sacred Scriptures; having a thorough conviction of the truth of the facts recorded, and of the correctness of the principles laid down. Without these our minds will be led into a dark mysterious void, instead of having our thoughts carried up to the Father of light and of life.

"With these principles as our ballast, we may launch our bark, without any apprehension, upon the broad ocean of science, explore its coasts, and fathom its deptlis ; but destitute of them our vessel will be in perpetual storm amidst rocks and shoals, without a rudder, a compass, or a chart.

"Thus equipped, you may accompany the geologist into the bowels of the earth, and examine its wondrous structure; and you will return with an overwhelming conviction that the 'Eternal God made the earth by his power, that the pillars of it are his, and that he has set the world upon 
them.' With the astronomer you may ascend the skies, contemplate with ecstasy the movements of the heavenly bodies, and with the scientific Psalmist you will exclaim, 'The heavens declare the glory of God, and the firmament showeth his handiwork.' With the voyager you may visit distant climes, and viewing man in all his multiplied and varied characters, you will be convinced that 'God hath made of one blood all nations of men for to dwell on the earth.' Thus it is that in every age the evidences of revealed religion have advanced with the progress of sound knowledge. Indeed, it cannot be otherwise; for the God of Nature, whose operations it is the province of science to explore, is the God of the Bible; and, as the God of truth, he cannot set forth in his word principles at variance with those which, as the God of Nature, he has established in the material world. Both systems of knowledge, thus emanating from the same source, must harmonize with each other; for the Bible is something like a new edition of the book of nature, with a splendid appendix, which makes known the wonderful scheme of human redemption. If there is any apparent discrepancy in these editions of this same great work, it arises from our inability rightly to decipher the characters employed." 
"If His word onee teach us, shoot a ray

Through all the heart's dark chambers, and reveal

Truths undiseerned but by that holy light,

Then all is plain. Philosophy baptized

In the pure fountain of eternal love,

IIas eyes indeed: and, viewing all she sees

As meant to indicate a God to man,

Gives Him his praise, and forfeits not her own."-Cowper.

The smallest fragment of coral is an object of interest. It is covered with perforations, but these punctures are not intended merely to add to its beauty. Every one of these little holes, or cells as they are called, was the habitation of an industrious polype. During its whole life it was building up its beautiful abode, and that without any painful effort on the part of the inmate, which was all the while enjoying itself amidst the eastern waves, spreading out its numerous tentacula in search of food abounding in the waters; or if threatened with being made the prey of some rapacious neighbour, ready on the slightest warning to retreat into its coral cave, where it was safe as amidst the munition of rocks.

When we admire a specimen of coral on our mantelpiece or in the cabinct of the curious, few are aware that we see not half its beauty. We have before us a portion of 
a beautifully built city; but where are its gay and active inhabitants? When in its native position in the deep, the numerous inhabitants appeared in bright array at the portals of their houses, like a happy assemblage of living flowers, not inferior in beauty to the flowers which adorn our gardens. Many of our sailors, who bring home to their friends beautiful fragments of coral, are not aware that they were once inhabited; for as they were collected when left uncovered by the tide, the inmates were unseen, having retreated into their moist cells till the waves should revisit them. A ship-master told me that on his first voyage to the South Seas, being delighted with the beautiful corals which abounded on the shore, he resolved to bring home presents to his friends in Scotland, and laid in a good supply; but he had not been many days at sea when his collection became so unsavoury that he was glad to throw the whole into the deep. On a second voyage he profited by past experience, and having enclosed his corals in a net he plunged them into the sea, and fastening the net by a rope to the stern, he allowed it to be dragged in the wake of the vessel for several days. When hauled up at the end of this time, the corals were found to be sweet and pure. The little scavengers of the deep had entered the minutest cell, 
and had eaten up what, in consequence of putrefaction, would soon, as on a former occasion, liave sent forth an ofiensive odour.

How little do we think of the constant care of God for the comfort and happiness of his creatures. He gives even the minutest of them their food in due season, and very often, in furnishing a table for them, he is, through their instrumentality, removing what would not only have led to the discomfort, but would have proved injurious to the health of his rational creatures. Were the millions of animals that are constantly dying allowed to lie till they were utterly decomposed, they would pollute the waters and spread infection in the air. There are, however, on land, beetles that are grave-diggers, and worms that drag into their holes in the earth dead animal and regetable matter. If a naturalist wishes to have a well-clcaned skeleton of bird or fish, he has only to place it in a pond filled with tadpoles; or if he be in Eastern lands, let him expose it for a night to a colony of white ants, and every particle of flesh or fish will be eaten away, and the beautifully-cleaned skeleton alone will remain. How delightfully refreshing is it to walk on the sea-shore, where a person fecls as if he were drinking in health to both body and mind;-and yet 
the shore would be far from being either pleasant or wholesome if all the rejectamenta of the deep were allowed to remain. But man has discovered that what the ancients accounted worthless seaweed, is a precious gift from the sea to the land, and it is consequently carted away, often miles inland, that it may impart a richer verdure to the pasture-fields, and greater fertility to what is under the plough. There are also innumerable little creatures on the shore ready to feast on the dead animals brought to them by the tide. The very mice from the adjoining sand-hills know the time of low water, and though they do not venture forth in broad daylight, they may often be seen foraging among the seareeds in the evening. Flocks of sea-birds, howerer, carry on their operations by day; and even landbirds know the turn of the tide, and flock down to cater on the strand. Rooks fail not to visit the shore, that they may feast on the shell-fish forsaken by the tide. The sagacity they exhibit in reaching the contents of those bivalves that are closed, and which their strong bills could neither break nor open, is deserving of notice. They carry them up to a considerable height, and, allowing them to drop on the rocks, find on their descent that they are broken, and that the feast of shells is ready spread for them; or, if not 
broken by the first fall, they carry them up to a greater height, that they may descend with increased impetus. Such are some of the various ways in which an all-wise God beneficently acts unseen, overruling for good so many of the actions of his creatures.

To return to our corals, however. If the smallest fragment of coral is an object of interest, what bounds shall we set to our admiration when we consider that there are thousands of islands, many of them of great extent, the materials of which are chiefly formed by the coral-working creatures; - that in the Pacific Ocean, and amidst the South Sea Islands, there are coral reefs extending hundreds of miles, which have all the appearance of being the work of these little marine artificers! We may state that there is a considerable diversity of opinion as to the extent of the operation of coral polypes in the formation of these islands and reefs, some arguing that only the upper portion can be the work of the polypes, as it has been proved that they cannot live at a greater depth than 30 or 50 fathoms. Even granting that only 50 fathoms, or 300 feet, of the upper part of the reef is their workmanship, how prodigious even then would be the accumulated amount of their operations! How much even then would they cast into the shade the 
mightiest operations of man! In a remote age the Egyptian kings, with a great nation at their command, built the pyramids which are still the wonder of the world; but the pyramids are but like children's baubles compared with those reefs and islands, to the formation of which these tiny worms have even on the lowest estimate so essentially contributed.

As the formation of coral reefs is one of the most wonderful things to which the eye of the naturalist can be turned, and as it is allowed by all that zoophytes contribute much to the mighty work, we are tempted to dwell a little on the subject, and to give a brief account of some of the views that have been taken of the matter.

It was for some time an opinion entertained by many that as zoophytes cannot live at any great depth; they select for the commencement of their operations some favourable situation, such as the summit of submarine mountains; and as many of the reefs are of a circular or an oval form, this was accounted for by supposing that the little creatures take as the foundation of the reef the crater of a submerged volcano. It will scarcely be thought that this is a very tenable supposition when we consider that the circumference of many of the reefs would measure from fifty to 
a hundred miles. These would indeed have been the craters of tremendous volcanoes! Instead of enumerating the various theories, we shall merely give a short account of one which has been much countenanced, and which certainly secins the most plausible and satisfactory of any with which we are acquainted. We refer to the theory of the philosophical-minded Darwin, first, we believe, brought forward in his interesting journal of the Voyages of the Beagle, and afterwards more fully brought out in a separate publication. He divides reefs into three classes: first, fringing reefs; second, barrier reefs; third, atolls. The fringing reef is that which is near to the shore, and aloug the shore of an island or of a continent. The barrier reef is along the shore of a continent or around an island, but at the distance it may be of many miles from continent or island. The barrier reef encloses an island, with some miles of sea betwixt the reef and the island. The atoll encloses only water, and the enclosed space is often called a lagoon. In order to understand Mr. Darwin's theory it is necessary to remember his three kinds of reefs, though the fringing reef, the barrier reef, and the atoll are only different phases of the same thing. We are to bear also in mind that though the sea is proverbially changeable, the 
stable earth, as we usually call it, is more changeable even than the sea. We speak of the everlasting hills, but we know that there was a time when the mountains had not been brought forth,- - that many of our own mountains bear the strongest internal evidence that they have been upheaved from the depths of the sea; and we know also that the same power that thus brought them forth could again easily submerge them in the watery deep. On a small scale, there was an exemplification of this not long ago in the Mediterranean, where what was called Graham's Island arose in the sea, but after being visited by many as a new island, again hid itself in the dark profound. On the coast of South America, some thirty years ago it is well known that the shore for several miles was considerably elevated, leaving the seaweeds to wither and the fish to perish on dry land; while on other places of the coast there were depressions, the sea gaining upon the land. Many of the peaked islands in the Pacific are evidently of volcanic origin; and it is on this interchange of upheaval and depression, but more especially of gradual and long-continued submergence, that Darwin's theory proceeds.

Let us take, then, one of these peaked volcanic islands, that has been elevated to the height of 6000 feet above 
the level of the sea, and let its diameter at the base be twenty miles. Let us suppose that it has reached its ultimatum of upheaval, that all for a time is stable. Around its shores our little active polypes will begin their operations, and in the course of time will form around the island a fringing coral reef, the breadth of which will be considerable if the shore, instead of being precipitous, is of a shelving nature. Let us suppose, that when the fringing reef is formed, the island begins to be depressed, to sink again into the deep, and that this submergence for a a lengthened period slowly but gradually goes on. The fringing reef, however, goes down along with it; and were the polypes to raise their reef no higher they would soon perish, for it has been ascertained that they cannot live in a great depth of water. But it is their delight to work, and their instinct to carry on their operations upwards; so that while the island is descending into the depths, their reef is ascending. Let us suppose that the island is conical, and that its diameter, which was twenty miles at the base, is only ten miles half-way to the summit; and let us further suppose that the submergence has proceeded till the island, which was originally 6000 feet in height, is only 3000 , and its diameter at the water's edge 
now reduced by a half also, so as to be only ten miles. Where now is the reef? It has not perished; its active artificers have been incessantly employed in rearing it up, and it is now at the surface of the water; but it is no longer a fringing reef, but far out at sea; for though close to the shore when the diameter of the island at the water's edge was twenty miles, it is far from the shore now, when the diameter of the island at the water's edge is only ten miles. The sea now occupies the intervening space, so that on all sides the reef, which is now called a barrier reef, is five miles from the island. Let the sinking of the island gradually go on, and let the little polypes not slacken their operations, and in process of time the island will wholly disappear, and the reef, which the indefatigable marine builders have raised to the surface, will be the only monument to show that there ever was an island within the enclosing circle, which is no longer a barrier reef, but is known by its Indian name-an atoll; and the lagoon of placid waters, surrounded by the reef, is now twenty miles in diameter, being the diameter of the island when the original fringing reef was formed around its shores.

So long as the island was sinking the polypes wrought upwards, but when the sinking ceased and the reef had 
been raised to the surface, the polypes could raise it no higher, for all their materials were found in the waters, and they could not live out of the sea. The sea, for a time, would roll over it, but when it reached the surface, seaweeds and branches of trees, and fragments of wrecked vessels, and many other things floating in the deep, would . be entangled among the branching corals, and as they became decomposed, soil would thereby be formed. The reef, in general, is observed to be the highest to the windward, for though the hurricane might break off large fragments they would often be heaped upon the reef; and under water the polypes would soon repair the damage. Coralsand and shells broken by the storm would often be tossed up and deposited on the reef. Penguins and other guano birds would find it a resting-place, and would enrich it by their droppings before it was a safe place for their nests. The sea would bring the seeds of various plants; cocoa-nuts from adjoining islands would often be wafted by the waves, and, as soon as any soil was formed, would vegetate and spring up. Flowers, in course of time, would be intermingled, and, ere long, the reef would become a beautiful garden, abounding in all the shrubs, and trees, and flowers, and fruits, which grow in such beauty and luxuriance in southern climes 
Now, while this is the way in which the theory accounts for the formation of barrier reefs surrounding islands, and of atolls where no island remains, it is equally applicable to barrier reefs extending longitudinally for many miles along the coast of a continent at a considerable distance from the shore, for at first there were fringing reefs close to the land, but when by upheaval the shore became a raised beach, the reefs, when built up by the polypes, were far out at sea.

The theory accounts satisfactorily also for those gaps or gateways, one or more of which are found in every barrier reef or atoll. The existence of such gaps might at first seem fatal to the theory, for it might be said, had the polypes reared the reef from the foundation, they would have carried on their work uniformly, and would have left no gaps; and yet had there been no gaps no vessel could ever have fled for refuge into these lagoons of broad, peaceful, sheltered waters. Wherever there is a high-peaked island, the clouds, attracted and caught by the peaks, are condensed into water; the water forms rills, and the converging rills in many cases become rivulets flowing into the sea. In an island of considerable size we may well suppose two or three of these mountain streams at different places will enter the deep. Wherever a stream enters there is no fringing reef 
formed, for fresh-water kills the little marine polypes. This accounts for the commencement of the gap, and it is not difficult to account for the continuance of it. It might be urged, that when the fringing reef has become a barrier reef, and is so far removed from land that the stream in its fresh state canuot reach it, then the polypes would resume their operations, and would soon fill up the gap. This would, doubtless, be the case had there been only the influence of the fresh-water as a preventative, but the tide, in its constant ebbings and flowings through the gap, would always deposit mud and sand, which would be as injurious to the polypes as the fresh-water, so that the gap begun by the stream continues after the stream has lost its freshness, as the rush of the tide and the filth that it carries along with it is injurious to the life, and consequently to the work, of the polypes. Hence it is that wherever there is a gap in a barrier reef, it has been observed that it is opposite to a place in the land where a stream enters the sea.

We trust we may be excused for dwelling so long on the mighty works of zoophytes in the Pacific Ocean, as they are the kindred of those that inhabit our own seas. Our most distinguished naturalists delight to write of them. "Every one," says my excellent friend Dr. Jolınston, in his 
'History of British Zoophytes,'- "every one has read of the coral islands of the tropical seas-how they grow from the fathomless profound, and how they rise to-day by the operations of puny insects, which, in countless numbers, and in untold generations, effectuate changes on our globe, superior, perhaps, to what all other animals united do, and to which the greatest achievements of intellectual man sink to insignificance." Still stronger is the language of Dr. Macculloch, in his 'History of the Western Islands.' "Their plants," says he, "are made of stone, and they build dwellings. Dwellings! they construct islands and continents for the habitation of man. The labours of a worm which man can hardly see, form mountains like the Apennines, and regions to which Britain is as nothing. The invisible, insensible toil of an ephemeral point, conspiring with others in one great design-working unseen, unheard, but for ever guided by one great volition,--by that one volition which cannot err,-converts the liquid water into the solid rock, the deep ocean into dry land, and extends the dominions of man-who sees it not, and knows it not,over regions which even his ships had scarcely traversed. This is the great Pacific Ocean, destined at some future period to be a world. That same power which has thus wrought 
by means which blind man would have despised as inadequate-by means which he has just discovered-here too shows the versatility, the contrast of its resources. In one hour it lets loose the raging engines, not of its wrath, but of its benevolence, and the volcano and the earthquake lift up to the clouds the prop and the foundation of new worlds, that from those clouds they may draw down the sources of the rivers, the waters of fertility and plenty."

"Millions of millions thus from age to age, With simplest skill and toil unweariable,

No moment and no morement unemployed, Laid line on line, on terrace terrace spread, To swell the heightening, brightening, gradual mound,

By marvellous structure climbing towards the day.

Each wrought alone, yet altogether wrought

Unconscious, not unworthy instruments

By which a hand invisible was rearing

A new creation in the secret deep.

Omuipotence wrought in them, with them, by them;

Hence what Omnipotence alone could do

Worms did. I saw the living pile ascend,

The mansoleum of its architects,

Still dying upwards as their labours closed.

Slime the material, but the slime was turued

To adamant by their petrific touch :

Frail were their frames, ephemeral their lives,

Their masonry imperishable." $-J$. Montgomery. 


\section{HISTORY OF ZOOPHYTOLOGY.}

"Mankind must necessarily be diversified by various tastes, since life affords and requires such multiplicity of employments, and a nation of naturalists is neither to be hoped or desired; but it is surely not improper to point out a fresh amusement to those who languish in health, and repine in plenty for want of some source of diversion that may be less easily exhausted; and to inform the multitudes of both sexes who are burdened with every new day, that there are many shows which they have not seen."-Dr. Samuel Johnson.

Dr. Samuel Johnson, from whom the above is taken, with all his talent and with all his rich stores of knowledge, was not a naturalist, and few comparatively in his day had paid any attention to natural science. Very few in Great Britain had at that time any acquaintance with Zoophytology. It is little more than a century since it began to be regarded as a distinct department of natural science. Before entering on the History of British Zoophytes, it may be interesting and useful to give some general history of the science, and a brief account of some of the naturalists to whom the science has chiefly been indebted. It was customary of old in Scotland to raise cairns as monumental remembrances of departed chieftains who had distinguished themselves in their day and generation, and 
every one who had a respect for the memory of the deceased brought a stone to add to the heap. Very willingly then would we, as a humble member of the Zoophytic clan, add our stone to the cairn of the chieftains that have gone before us, and if in our poverty we have nothing fresh to contribute, we will lift the stone which our masters have added, and having held it up and looked at it with reverence, we shall respectfully return it to the venerable cairn. In this brief sketch, as in almost everything else in this little work, I shall chiefly draw from my respected friend Dr. George Jolnston, whose admirable work on British Zoophytes is so well known and so much valued in the scientific world.

Those natural productions to which our attention is to be directed were called zoophytes, it is probable, at a time when it was thought by many that they were a connecting link betwixt the animal and the regetable kingdoms; that though it could no longer be denied that they contained animals, yet that they were indebted for their growth to an inherent principle of regetation. The name, though no longer regarded as appropriate in this sense, may still be retained as suitable for some of them at least, as having the outward appearance of sea-plants, but being in reality formed by the little polypes inhabiting their numerous tubes or cells. 
Long had they been regarded as within the domain of the botanist. He laid claim to them as his subjects on various grounds. They often had the external appearance of little shrubs ; - they did not, like animals, move from place to place, but remained permanently in the same situation, attached to other objects by fibres much resembling roots of sea-plants. Some, from their hard and stony nature, were disposed to place them in the mineral kingdom, alleging that they either were crystallizations formed from calcareous sediment, or by some natural incrustation of seaweeds. In support of these theories more might have been adduced than at that time they were able to do. It is now found that what were called lithophytes, nullipores, and corallines, do really belong to the vegetable kingdom, - such as Jania rubens, Corallina officinalis, and the various Melobesice; and as such they are figured and described in Harvey's magnificent 'Phycologia.' How they contrive to clothe themselves in these stony habiliments, is one of the secrets of Nature known only to Him who can mix flint with the green integument of Equisetum, and iron in the stems of some of our cereal grasses. That Jania rubens and the other nullipores, however, are of vegetable growth is no longer matter of conjecture, for on the application of a powerful acid their calcareous clothing is 
removed, and they stand forth in their nakedness as true vegetables, - so that the mineralogists must give them up.

Nor would those who favoured the theory of crystallization have less to say; for certainly there are crystallizations which have every appearance of belonging to the vegetable kingdom. There are agates which go under the name of moss-agates, and there are the pretty native mocha-stones, some of which I have collected in the north of Ireland, which contain what have all the appearance of beautiful mosses, though it is now well known that they are mincral crystallizations. In a limestone quarry at Moncymore, in Ireland, I gathered nodules which, on the purely white calcareous ground, had, in dark colours, drawn by the inimitable pencil of Nature, figures which one might have taken for impressions of some of the finest specimens of muscology in the antediluvian world. $\Lambda$ the lead-mines at Carsphairn, in Gallowar, I got a dendritic crystallization of manganese, one of the finest I had ever seen. The stone was greywacké, but, as if to prepare the canvas for the intensely black pencilling of manganese, there was on the stone a white calcareous coating on which the figure was laid in a branching way, three inches in length and two in breadth, like a little shrub, or rather like a marine plant, 
such as a Delesseria alata. Beautiful as this was, it was equalled, if not surpassed, by specimens given me by a friend who gathered them at Tintock, a well-known hill in Lanarkshire. The stone was fine reddish felspar, and on this delicate ground the dark crystallizations arose some inches in height, much resembling a miniature grove of elegant pine-trees. And these specimens, worthy of a place in any cabinet, could be gathered in abundance, being broken down for road-metal, soon to be trodden by the foot of man and horse, or to be triturated by the crushing wheels of aristocratic carriages or of heavy ignoble wains.

It is rather curious that a few hours after I had written the description of these beautiful crystallizations, I incidentally got some insight into the way in which they are formed in the great laboratory of Nature. The process, in all likelihood, is known to many; but as it was a pleasant little discovery to me, I shall mention it for the instruction and amusement of some of my young friends-who may be as ignorant of the matter as I was myself. Having some iodine in a hermetically sealed phial, I had occasionally amused myself and others by heating, the phial at the fire, or at a candle or gas flame, and seeing it immediately filled with most beautiful violet-coloured vapour. Wishing to 
gratify some ladies who were fond of natural science, I put a little iodine into a small phial, and having corked it, I thought, before giving it to the ladies, that I would try whether it answered my expectations; so, holding it in the flame of the fire, I soon had the pleasure of seeing the little bottle filled with the violet* fumes. The vapour disappeared so soon as the phial cooled. This I expected: but observing that there was a deposit on the glass inside, I applied a pretty powerful pocket-lens to it, and was delighted to find that the deposit which dimmed the glass consisted of beautiful dendritic crystallizations very much resembling those moss-like figures which $I$ had admired on the Irish limestone. This is an experiment which, with the same enclosed particles of iodine, may be repeated as often as you choose; and on every repetition there will be a new set and arrangement of figures, like the numberless changes that take place on shaking a kaleidoscope.

When theories are plausible, they often keep their ground for a considerable time in the minds of many, even after accurate observers have become acquainted with the truth, and have ventured to publish it. The light of truth on this subject began to dawn about the close of the sixteenth

* Iodine takes its name from the Greek word for a violet. 
century. Imperato, a Neapolitan, seems to have been the first to state, as the result of his own observation, that corals and madrepores were the work of living creatures who dwelt in them. What reception his publication met with from the naturalists of that day we have not been able to learn. Though this work was illustrated by figures, a second edition of it did not appear till seventy-one years afterwards (1672), when the author, I doubt not, had passed away from the land of the living. Even then it seems to have been little read, for when Peysonnel, more than half a century afterwards, communicated the same discoveries to the Academy of Sciences in Paris, they deemed it quite new to them, and they appear to have treated the discoverer with scorn as a fanciful dreamer, or as a presuming upstart, who wished to be wiser than his neighbours.

There were several things that contributed to the unfarourable reception which Peyssonnel's discoveries met with. Some time before, Count Marsigli, a scientific Italian, had written on the subject, and though he described the animals he had seen in the corals, he had represented them as the flowers of the corals. It was too venturesome for a young man but little known to enter the field against a learned Count, and with that modesty that generally accompanies 
true worth, he entrusted the statement of his opinions to Réaumur, who was to conceal his name. Even in this choice he was unfortunate, though probably at the time he could not have selected a better. Réaumur stated his opinions, but so far was he from supporting them that he wrote an essay, with objections to what he considered a new theory, and gave a preference to the theory which regarded them as vegetable productions.

It is recorded of Galileo, when he rose from his knees after making the humbling recantation of his novel and then heretical doctrine of the revolutions of the earth, that he said, sotto roce, "It still moves ;"- -so we doubt Peyssonnel, in spite of the taunts and sueers of the Academicians, would persist in saying they are neither flowers nor crystallizations, but living creatures. He had all the world against him till 1741, when,-owing to the discoveries of M. Trembley, respecting the animality of the fresh-water IIyctra, and the Pluhatella, which excited such wonder,-the tide fairly turned. Bernard de Jussieu and some other distinguished naturalists were lerl to examine the marine corals and corallines, and soon found that Peyssonnel's doctrine was the true one, and extended to many more zoophytes than he had examined. Even Réaumur was convinced, and did justice at last to 
-Peyssonnel by becoming the hearty advocate of opinions which he had formerly sought to refute. Peyssonnel was still alive and no doubt would hear with much satisfaction the change which had taken place, and, encouraged by it, he sent in 1752, to the Royal Society of London, a treatise on coral and other marine productions, the result of his own observations for thirty years. At first it was favourably received, but unfortunately for Peyssonnel, Dr. Parsons, a naturalist of some reputation and of great influence in the Royal Society, undertook to refute the statements made by Peyssonnel; and at a period when few of the members of the society had tested the matter by personal observation, the plausible blustering of Parsons seems for a time to have overborne the truth. He considered the animals in the corals as mere accidental settlers, totally inadequate to the great works ascribed to them. "And indeed it would seem to me," says Parsons, "much more difficult to conceive that so fine an arrangement of parts, such masses as these bodies consist of, and such regular ramifications in some, and such well-contrived organs to serve for vegetation in others, should be the operations of little, poor, helpless, jelly-like animals, rathẹr than the work of more sure vegetation, which carries on the growth of the tallest and largest trees 
with the same natural ease and influence as the minutest, plant."

At the same time also, Henry Baker, who had written on the 'Employment of the Microscope,' discharged his last arrow in defence of the mineral theory. In using the microscope, he liad no doubt observed the beautiful and regular crystallizations which salts and earths and metals assume, and he stoutly argued that the seeming sea-plants were nothing more than crystallizations. "The rocks in the sea," he says, "on which these corals are produced, are undoubtedly replete with mineral salts, some whereof near their surface, being dissolved by sea-water, must consequently saturate with their saline particles the water round them to a small distance, where blending with the stony matter with which sca-water always abounds, little masses will be consti. tuted here and there and affixed to the rocks. Such adhering masses may be termed roots: which roots attracting the saline and stony particles, according to certain laws in nature, may produce branched or other figures, and increase gradually by an apposition of particles, becoming thicker near the bottom where the saline matter is more abounding, but tapering or diminishing toward the extremities where the mineral salts must be fewer in proportion to their 
distance from the rocks whence they originally proceed." Where the truth is not known, how plausibly can error be dressed up, so as to satisfy many, and keep them from searching for the truth!

But though error in various forms was more acceptable to many than truth, the glimpses of truth that had been obtained revived discussion, and set men to think and to observe. So long as there is no actual observation the war of words and of opinions may be carried on and victory claimed by the several disputants, though not one of them may be entitled to bear away the palm. In this instance, however, it was soon to be won by a member of the Royal Society, who though he could not fail to hear of the statements made by MM. Peyssonnel, Trembley, and others, does not seem to have been influenced by them, as he brings forward his own most important statements as the result of his own observations made when engaged in botanical pursuits. The person to whom I refer was John Ellis, a London merchant, who from seeing the polypes in some of our British zoophytes, caught a convincing glimpse of the true state of the matter, and prosecuted the study with such ardent zeal that in 1755 he publishèd a work entitled ' An Essay towards a Natural History of Corallines and other 
marine productions of the same kind, commonly found on the coasts of Great Britain and Ireland ;- "A work," says Dr. George Johnston, a most competent judge, "so complete and accurate, that it remains an unscarred monument of his well-earned reputation as a philosophical inquirer, and is even to this day the principal source of our knowledge in this department of natural history."

As a proof of the rapid spread of the reputation of this work, we may mention that, before a year elapsed, a translation of it into the French language was published at the Hague, dedicated by M. Hondt, the translator, to her majesty the Queen of Srreden. I have a copy of that work published in 1756, with illustrations from the same plates that were employed in the original work. And yet, precious as the work is, even in a translation, it is mortifying to find that it has never been read, for it has remained uncut. This would say little for the popularity of the treatise, did we not conjecture that it must have fallen into the hands of persons unacquainted with the French language, and therefore ignorant of the value of the treasure in their possession.

It is very interesting to learn from the relation which Ellis himself gives, the way in which the light broke in upon him. About the close of the year 1751 (and one liundred 
years ago), having received a curious collection of marine plants and corallines, soine of them from the Isle of Anglesey in North Wales, and others from Dublin, and wishing to preserve the rarest and most beautifully coloured of them, he spread them on paper in water, laying out with care their ramifications and fine filaments, according to the method of M. Buttner, a celebrated botanist of Berlin, to whom, he says, he was indebted for many other very useful practices in botany, so that we see that this mode of preparing seaweeds, so common now, was new to this country a century ago, though from what follows he does not seem to have pressed them so as to cause them to adhere to the paper, which is now the general practice, but kept them free, as some still do, when the weeds are meant for fancy-work. After the plants were dried, he fastened them on boards covered with white paper, in such a manner as that they formed a kind of landscape. His friend Dr. Hales, having one day seen his pictures thus formed, was so delighted with them, that he wished him to prepare some of a similar kind for her Royal Highness the Princess Dowager of Wales, in order that the young princesses, her daughters, might amuse themselves in trying to imitate them; and that the marine paintings might be as perfect as possible, he besought him 
to collect all the different kinds of sea-plants found on our shores. He complied with the request, and being aided in his search by Mr. Shelvocke, secretary of the General Post Office, and by some friends in Ireland, he prepared the landscapes and had the honour of presenting them to her Royal Highness, by whom they were graciously received; and we may add, that these very pictures, which were prepared for the amusement of the young princesses, have long survived the royal damsels, and are still to be seen carefully preserved in the British Muscum in Isondon.

The great variety of plants that Mr. Ellis received at this time led him to set about arranging them according to their several classes, and genera, and species, taking as his guide Ray's 'Synopsis of British Plants.' That he might do this more accurately, he employed the microscope; and, by the aid of this instrument, he discovered that some of them were so different in their nature, that he was more inclined to rank them in the animal than in the vegetable kingdom. Having arranged them according to his mind, he presented them to the Royal Society, along with a dissertation explaining his views with respect to their nature; but as he still had doubts as to some of them, he went, in August, 1752, to the Isle of Sheppey, near the coast of 
Kent, that he might examine these marine productions in their native locality, more especially those respecting which he was doubtful, taking with him his microscope, and a skilful artist to prepare figures of the objects examined. On examining them in sea-water, very soon were his doubts dissipated, and he became thoroughly convinced that what had been regarded as plants were nothing else than the nests of animals, which he saw alive and which protruded from the cells in which they were enclosed, organs like little branches or filaments.

In June, 1754, Mr. Ellis went to the coast of Sussex, taking with him Mr. Ehret, to sketch figures of whatever the microscope enabled them to discover. He sent an account of this excursion, along with the figures, to the Royal Society, who honoured the whole with their approbation. In plate 9, for instance, he gives a very good figure, of the natural size, of Antennularia antennina, and also one of its branches magnified such as they saw it in the water by the aid of the microscope; and in this are seen the polypes, sending from their cells their tentacula in the form of little star-fish. In plate 29, also, there is a figure of Flustra foliacea of the natural size, with one of the polypes magnified. It was then also that he discovered the true nature and 
use of the vesicles which are seen abundantly in many of the zoophytes. Some who had observed them thought that they were merely air-vessels to aid in floating the corallines, like the air-vessels which answer that purpose so well in many marine plants. So long as corallines were thought to belong to the vegetable kinglom, these vesicles had been regarded as the seed-vessels, and Ellis himself had at first been disposed to regard them as such. He now discovered, however, that these vesicles were the habitations of the young polypes, - that they might be regarded as corresponding to the buds proceeding from the bodies of freshwater polypes, only that, like the parent, they were defended by a calcareous covering, and that when they approached maturity they dropped off, to become independent animals, of the same kind as those from which they sprang.

Not only did Ellis fully satisfy himself that what had formerly been considered regetable productions were the habitations of little animals, by which they were formed, but he succeeded in rendering these little ereatures permanently visible, so that they could at any time be shown to those who were still sceptical as to their existence. IIitherto he had been able to exhibit, when he returned to town, only the dried specimens, and as the polypes, on 
being withdrawn from their native element, shrank into their cells, where they were dried, and unseen, it might be questioned by some whether they ever existed. By more than one way, which he describes, he succeeded in causing such instantaneous death, that the little polypes had not time to withdraw into their cells, but remained in the exposed state in which they were found when the sudden catastrophe came upon them, so that, by being put in this condition into spirits of wine, they could be preserved for any length of time to afford ocular demonstration that they had really existed. Alas! should not this sudden death of the polypes remind us, that the King of Terrors may come upon us as a thief in the night, at such an hour as we think not? At whatever time death comes on the little polypes, it finds them always actively employed in answering the purposes for which they were created;-they have enjoyed life, and have no account to render. Is it so with man? He must render an account. Is he always ready to render it with joy? How dreadful to be suddenly cut down in a state of rebellion against Him to whom he is responsible, and who is to be his righteous Judge. We remember reading that when the ruins of Hęrculaneum were first opened up, the position in which the skeletons were found 
showed how suddenly the catastrophe had come upon the inhabitants, and that one skeleton was thought to be that of a slave arrested by death in the very act of stealing a bag of money from his master. What a lesson to us, to have our loins girt about and our lamps burning, and to be of them who are waiting and 'watching, and ready for the coming of their Lord.

Though the doctrine taught by Ellis was the same that had been maintained by Peyssonnel, Trembley, and latterly by Réaumur, he so fully illustrated that matter, that he may be said to have established its truth, effecting a revolution in the opinions of the generality of scientific men. He showed in those zoophytes of a compound nature, that though a single animal inhabited each cell, yet they were united, "by a tender thready line to the fleshy part that occupies the middle of the whole coralline; - that the polypes were organically connected with the cells, and could not remove from them; - and that that which seemed a plant, was the covering, whether horny or calcareous, of the hydra, and was as much an animal structure as the nails of a man, the horns of a bullock, or the shell of a tortoise." It is not necessary that we should further trace the history of Zoophytology; we may merely mention some of 
the authors who have adopted Ellis's views and followed them out with great success. For a long time, however, naturalists seemed to have rested satisfied with what had been done. The standard work of Ellis was published in 1752 ; and that century was allowed to close, and more than a fourth of the present century to pass away, before we had another work on British zoophytes. In 1828, however, my distinguished friend Dr. John Fleming, now Professor of Natural Science in New College, Edinburgh, published his ' History of British Animals,' and at the close of the volume our little zoophytes pass in array before us; and within small compass he gives an excellent description of them, as the result of his diligent research and most accurate observation. This admirable book, along with its still more learned forerunner, 'The Philosophy of Zoology,' gave new life to natural history, and laid the scientific world under great obligations. "To his labours and writing," says Dr. George Johnston, "I am inclined to ascribe a very considerable share in diffusing that taste for natural history which is now abroad."

In 1838, ten years after the publication of the 'British Animals,' Dr. George Johnston, previously well known as the author of several works on natural history, published, in 
Edinburgh, his interesting work, the 'History of British Zoophytes,' alrearly referred to. This was hailed as a most valuable production, and being favourably received, a second edition of it, in two volumes, was published by Van Voorst, in London. The second volume consists of plates from the felicitous pencil of his accomplished lady; and many of them were also engraved by her. These illustrations greatly enlance the value of this treatise, which is the standard work on this subject.

TTe might have greatly extended this history, but we have limited ourselves to short notices of those works that have taken in the whole field of British zoophytology. Our object, however, has becn answered by showing how matters now stand. The animality of zoophytes has been fully established; and how much has that widened the range for the contemplative naturalist, to adore the goodness of God. The microscope shows us that there are myriads of myriads of his creatures enjoying happiness, and by their works and by their very happiness proclaiming his praise, where formerly nothing but the sportiveness of crystallization, or at best the unconscious rorkings of regetation, were beheld. The happiness of these little creatures, especially when we take their numbers numberless into account, 
gives additional force to a beautiful passage in Paley's 'Natural Theology,' proving the goodness of God from the happiness of such multitudes of the inferior animals made to enjoy life. "It is a happy world after all. The air, the earth, the water teem with delighted existence. In a spring noon, or summer evening, on whatever side I turn my eyes myriads of happy beings crowd upon my view. 'The insect youth are on the wing.' Swarms of new-born fies are trying their pinions in the air. Their sportive motions, their wanton mazes, their gratuitous activity, their continual change of place without use or purpose, testify their joy, and the exultation they feel in their lately discovered faculties. A bee amongst the flowers in spring, is one of the most cheerful objects that can be looked on. Its life appears to be all enjoyment: so busy and so pleased: yet it is only a specimen of instinct life, with which, by reason of the animal being half-domesticated, we happen to be better acquainted than we are with that of others. The whole winged insect tribe, it is probable, are equally intent upon their proper employments, and, under every variety of constitution, gratified, and perhaps equally gratified, by the offices which the Author of their nature has assigned to them. But the atmosphere is not the only scene of enjoy. 
ment for the insect race. Plants are covered with aphides, greedily sucking their juices, and constantly, as it would seem, in the act of sucking. It cannot be doubted but that this is a state of gratification. What else should fix them so close to the operation, and so long? Other species are running about, with an alacrity in their motions which carries with it every mark of pleasure. Large patches of ground are sometimes half-covered with these brisk and sprightly natures. If we look to what the waters produce, shoals of the fry of fish frequent the margins of rivers, of lakes, and of the sea itself. These are so happy that they know not what to do with themselves. Their attitudes, their vivacity, their leaps out of the water, their frolics in it (which I have noticed a thousand times with equal attention and amusement), all conduce to show their excess of spirits, and are simply the effects of that excess. Walking by the sea-side in a calm evening, upon a sandy shore, and with an ebbing tide, I have frequently remarked the appearance of a dark cloud, or rather very thick mist, hanging over the edge of the water, to the height perhaps of half a yard, and of the breadth of two or three yards, stretching along the coast as far as the eye can reach, and always retiring with the water. When this cloud came to be examined, it proved 
to be nothing else than so much space, filled with young shrimps, in the act of bounding into the air, from the shallow margin of the water, or from the wet sand. If any motion of a mute animal could express delight, it was this : if they had meant to make signs of their happiness, they could not have done it more intelligibly. Suppose then, what I have no doubt of, each individual of this number to be in a state of positive enjoyment, what a sum, collectively, of gratification and pleasure have we here, before our view !"

In a delightful excursion which I greatly enjoyed many years ago in the yacht of Mr. Smith of Jordanhills, along with that great and good and most loveable man, the late Dr. Chalmers, who was so alive to the beauties of nature, I remember that looking around on a grand and beautiful scene at the junction of Loch Long and Loch-goil, he said, with deep emotion, "How wonderful that the Lord should make this sinful world so exceedingly beautiful !" I think it must have been the feeling that they were so worthy of being admired, that led our forefathers to people many beautiful secluded spots with fairies, as the ancient Greeks and Romans made their Dryads the inmates of the woods, and their Naiads, of the glens and streams. Well do I remember, 
in a nutting excursion in my early boyish days, when, wandering from my noisy companions, I came to a glade of surpassing beauty, watered by a tiny limpid rill, when I looked at the green sward, and the mossy hillocks, and the wild flowers, and the encircling copse of hazel intermingled with oak and ash, the autumnal tints of whose foliage was gilded by the beams of the afternoon sun, my admiration of the beautiful gave place to awe; for I thought surely this lovely spot must be the playground of fairies, who may be here though unseen. Fleeing, and yet trying not to seem to Hee, I steered towards the edge of the copse, casting at times a sidelong glance lest some of the green-coated little folk * should be at my heels; and guided by the sound of my youthful companions I was truly glad when I reached them in safety. Oh that, in riper years, I oftener felt the presence of Him who is invisible, and that whether in the field, in the family, in the sanctuary, or in the closet, I were oftener constrained to say, "Surely the Lord is in this place and I knew it not; this is none other than the house

* The fairy-folk being one of the names by which these little fays were spoken of, explains the origin of the name of one of our stateliest native flower's-Fox-glove, i.e. Folk's-glove. Our Scotch name, bloody fingers, is a kind of trauslation of Digitalis purpurea. 
of God and the gate of Heaven! It is a delightful thing to learn to see God in his works, and to admire them as his. He would then be present with us as our instructor; and though our eyes might be holden that we should not know Him, we should feel his influence, and we should say afterwards, "Did not our hearts burn within us while he talked with us by the way?" It is possible to taste the blessedness of the travellers towards Emmaus. "I am better acquainted with Jesus," said a departed saint lately taken away in his prime,- "I am better acquainted with Jesus than I am with my dearest and most intimate friend." "Enoch walked with God and was not, for God took him," and he will take us also if we walk with him-not indeed without tasting of death, but dispelling our doubts and fears, and making death our friend.

"Oh! could we make our doubts remove,

These gloomy doubts that rise, And see the Canaan that we love

With unbeclouded eyes!

Could we but climb where Moses stood,

And view the landscape o'er,

Not Jordan's stream, nor death's cold flood,

Should fright us from the shore."

One advantage that the study of Zoology has over that of 
Botany, however delightful and instructive, is, that it shows us more of the goodness of God. Flowers are like the stars of the earth, that show forth his glory; they are also the beautiful garniture of the earth as our habitation, and they proclaim also the coming of all manner of pleasant fruits. In the words of the Song of Songs we may say, "Come, my beloved, let us go forth into the fields; let us get up early to the vineyards, let us see if the vine flourish, whether the tender grapes appear, whether the pomegranates bud forth, and the mandrakes give a smell." But in the very lowest department of Zoology we deal with things that have life. The dexterous hand of man can form flowers so like to nature, that many would not discover that they are artificial. Mignionette was so natural-looking in the Great Exhibition, that we were told that a noble duke caused the shade to be removed, to be convineed by its want of fragrance, that it was not in truth the Frenchman's darling. But who of earthly mould could give life and voluntary motion to the smallest creature? This is God's doing, and it is marvellous in our eyes. We would not say, as some have done, that God is maximus in minimis-greatest in the smallest things;-for without controversy He is greatest in the great mystery of godliness - in the greatest of all 
INTRODUCTION.

his great works. But we may truly say, that he is great in the formation of the smallest of his creatures. He is great in the formation of even the least of the little zoophytes that inhabit the waters, and he is in them seen to be good as he is great. Look at a large frond of Laminaria saccharinco six feet in length and perhaps a foot in breadth, and in many cases you will see it pretty thickly covered with round silvery spots. These are Lepralice of different species. Examine them with a lens, and you will find that they are of exquisite workmanship. Had they not thus been "sought out" by you they might have perished,-their beauty unseen. But though unseen by man, the goodness of God would not have been unfelt. Every one of the silvery spots with which it was studded was a colony of living creatures taught by God to construct the beautiful habitations in which they lived. Their name was Legion, for they were very many; but they were not a legion of wicked spirits doing evil, and consequently miserable, but a legion of God's creatures doing good, actively employed in doing his will, and consequently happy. Though they had never been seen by man, God would not have lost his praise, for he gave them life, and rendered that life uninterruptedly happy. "O Lord, how manifold are thy works! in wisdom 
hast thou made them all; the earth is full of thy riches; so is this great and wide sea, wherein are things creeping innumerable, both small and great beasts. 'There go the ships; there is that leviathan whom thou hast made to play therein. These wait all upon thee, that thou mayest give them their meat in due season. That thou givest them they gather; thou openest thy hand and they are filled with good." It is the remembrance of this goodness and of the happiness imparted to creatures that camnot be numbered for multitude, which gives an additional charm to the study of Zoophytology. If one frond is the habitation of a million of happy creatures, how great must be the amount of happiness which God is giving every moment to the utterly uncountable myriads of his creatures that inhabit the deep.

By studying the nature and habits, and contemplating the happiness of these little denizens of the deep, we see the kind hand of God where our forefathers never thought of looking for it, and where it is probable we should never have seen it had it not been for the invention of the microscope. And this reminds us of the striking passage in which the lamented Dr. Chalmers compares the microscope and the telescope. "The one," said he, "led me to see a 
system in every star; the other leads me to see a world in every atom. The one taught me that this mighty globe, with the whole burden of its people and of its creatures, is but a grain of sand on the high field of immensity. The other teaches me that every grain of sand may harbour within it the tribes and families of a busy population. The one told me of the insignificance of the world I tread upon. The others redeems it from all insignificance; for it tells me that in the leaves of every forest, and in the flowers of every garden, and in the waters of every rivulet, there are worlds teeming with life, and numberless as are the glories of the firmament."

We read with wonder of upwards a hundred thousand human beings congregated in one Crystal Palace, and yet we think not that in a single drop of water taken from a pond, we may have, could our eyes behold them, a still greater number of God's living creatures, freely disporting as in a crystal palace, finding also their aquatic habitation stored with all that is necessary for the support of their happy lives. And so prolific are these little creatures, that Ehrenberg, the highest authority in such matters, calculates that in a few days a single individual may increase to a million, and that in a few days more the increase may be 
numbered by billions, trillions, and quadrillions. These are numbers that we can pronounce very glibly with the tongue, without attaching to the words any adequate idea of the immense multitudes of living creatures we are at the time speaking of. A friend of mine, on hearing his son, who had got some lessons in arithmetic, go very trippingly over his enumeration table, said to him, "George, you deal in mighty numbers; have you any idea of the meaning of these high-sounding words you are pronouncing? You seem quite familiar with quadrillions: for how much will you count for me a quadrillion of these peas, which I am now sowing in the garden?" "I will do it," said George, who was an off-hand lad, and thought he was making a good bargain with his father,- "I'll do it for twopence." George was safe had he known it; for he had only to make the reasonable demand that the matériel on which his arithmetical labours were to be exercised, should be produced, and his father must have owned that he could not furnish it; but George was glad to back out from the bargain, on being shown that though he were to live a hundred years, and spend every moment of this long life in the monotonous work, death would overtake the aged pulsecounter, when the ill-paid reckoning was scarcely begun. 
We have already shown, that, as many of these little creatures live on dead animal matter, they are of immense service in keeping the waters pure by removing what would soon have rendered them loathsome and deadly. But they are not only useful in removing what is corrupt and corrupting, but they emit what contributes to the salubriousness of the waters. It is one of the remarkable discoveries of science that the functions of animal life are reversed in infusorial animalcules, and that, instead of evolving carbonic acid gas, as other animals, by breathing, do, they evolve pure oxygen. The air-bubbles given out by water, in which these living "minims" abound, contain such pure oxygen, that a small bit of deal matchwood, on which a flame has just been extinguished, will burst into a flame again on being immersed in these bubbles. The truth of this rests on no less authority than that of Liebig, the celebrated German chemist, who tells us that he had himself ascertained it by experiment.

Gosse, in speaking of coralline, says, "Beyond its beauty, I know not that this little creature has any obvious claim on our consideration, except that, in common with other sea-plants, it gives out oxygen, and thus maintains water in which it grows in a state fit for the support of animal 
life. And here so wisely is the balance kept up betreen the animals which absorb oxygen, and the plants which evolve it, that, perhaps, the world could not afford to lose a single species of either, without derangement of the existing order which would be followed by manifest inconvenience."

As corallines, or nullipores, have now been ascertained to belong to the regetable world, though they are oxygen-yielding, we are not entitled at once to conclude that zoophytes are so also. We are not aware that the experiment has been tried with them; but how easy would it be to place a polypidom adhering to stone in pure sea-water in a glass where they might live and be treated in the same manner as Liebig did the animalcules, and the result would soon determine the matter. Our men of science are evidently disposed to think that they are water-purifiers, as appears from the following passage from Kirby's Bridgewater Treatise. "What particular function or office has been devolved by the all-wise Creator upon these zoophytes, which are produced so rapidly and in such numbers on the bed of the ocean and rocks, has not been ascertained. As in the case of a vast variety of other marine animals, they probably derive their nourishment from the contents of the water absorbed by their tubes; they may 
INTRODUCTION.

contribute their part to the depuration of the oceanic waters, and to the maintenance of the equilibrium amongst their inhabitants, however minute, which is necessary to their general welfare."

From the contemplation, then, even of these minute creatures of God, salutary instruction may be derived. "All His works praise Him," and it is our duty to help to proclaim His praise. "The praise of God's wisdom and power," says an old writer, "lies asleep and dead in every creature until man actuate and enliven it. I cannot, therefore, conceive it altogether unworthy of the greatest mortals to contemplate the miracles of nature, and that as they are more visible in the smallest and almost contemptible creatures; for there, most lively, do they express the infinite power and wisdom of the great Creator, and erect and draw the minds of the most intelligent to the first and prime cause of all things, teaching them as the power so the presence of the Deity in the smallest insects." From God's care of the tiniest of his creatures, may we not learn to put implicit trust in His kind and ever-watchful Providence if we commit ourselves to Him in well-doing, in dependence on the merits of his Son? If he clothe with such beauty the submerged rocks and caverns of the sea, and feed with unceas- 
ing liberality the myriads of almost invisible living minims of nature that have their dwelling-place there, how much more will he feed and clothe and protect those who are the adopted children of his own family, and the ransomed heritage of his own Son!

"I tell thee that those living things,

To whom the fragile blade of grass,

That springeth in the morn

And perisheth ere noon,

Is an unbounded world; -

I tell thee that those viewless beings,

Whose mansion is the smallest particle

Of the impassive atmosphere,

Enjoy and live like man;

And the minutest throb

That through their frame diffuses

The slightest, faintest motion,

Is fixed and indispensable

As the majestic laws

That rule yon rolling orbs."-Shelley. 


\section{CHAPTER II.}

\section{CLASSIFICATION OF BRITISH ZOOPHYTES.}

"With God let us begin, nor from him rove;

Him let us praise; Him ever serve and love;

The earth is His, and His the wide-spread sea,

And every living thing that therein be.

God's presence fills all space, upholds this ball;

All need His aid; His power sustains us all,

For we his offspring are, and $\mathrm{He}$ in love

Points out to man the way to Heaven above."-Aratus*.

THe word Zoophyte, as already said, was at first employed to designate various kinds of creatures that were thought to hold a middle place between animals and vegetables. With continental naturalists it is still used in this extensive sense,

* We have taken the liberty of making some changes in this passage from Aratus, a Cilician poet, probably of Tarsus, who lived about 300 years before the birth of Christ. We have given it a place at the beginning of this chapter chiefly because the words in Italics were quoted by Paul of Tarsus in addressing the Athenians. 
so that they comprehend under the term Zoophyte, starfishes, sea-urchins, sea-jellies, etc. By British naturalists it is employed in a much more limited sense. At first, as we have already said, it was employed as the name for creatures which from their form were thought to be the connecting link betwixt the animal and vegetable kingdoms, and to partake of the nature of both. The name was still retained after it had been ascertained that the creatures were decidedly animal, and partook in no degree of a vegetable nature. The name, no doubt, originated in the great resemblance which many of them bear to shrubs, mosses, lichens, and seaweeds, but it includes many where there is no such resemblance, hinging upon their being polypiferous. And it now excludes many included by early writers, such as corallines, lithophytes, and nullipores, first, because they were not imhabited by polypes, and now, because they are known to be vegetables. Sponges also are excluded, for though the ancients thought they were sensitive creatures, and modern naturalists are beginning to allow that they are endorred with life, yet as nothing like polypes has been seen inhabiting them, they are not ranked under the name of Zoophytes. "Zoophytes," says Dr. Johnston, " are all aquatic, avertebrate, inarticulate, soft, irritable, and contractile, 
without a vascular or separate respiratory or nervous systern. The alimentary canal is very variable, but the aperture to it is always superior, circular, edentulous, and surrounded by tubular, or more commonly, by filiform tentacula. Many are asexual, and it is doubtful whether any species has distinct sexes. The individuals (polypes) of a few families are separate, and perfect in themselves, but the great majority of zoophytes are compound animals, viz., each zoophyte consists of an indefinite number of individuals or polypes organically connected, and placed in calcareous, horny, or membranous cases or cells, forming, by their aggregation, corals or plant-like polypidoms."

There is also a tribe of beautiful little creatures sometimes called ciliated polypes, which I wish, in passing, briefly to notice; for though they do not strictly fall within our province, we gladly recognize them as relatives, not very far removed from our rightly accredited zoophytes, which all rejoice in being furnished with tentacula. As my object is to inspire my young friends with the love of nature, and with the love of Him who, while he gives to nature so many charms, should be much more endeared to us as the God of grace, I am not unwilling, at any time, to step aside from the strictly systematic path, to ponder for a 
little on any kindred object which, while it delights the eye, may improve the heart. Had not the telescope been invented, the milky way might still have been thought a white fleecy cloud spread over a portion of the heavens, instead of bright worlds, not placed in close proximity, but farther removed from each other than our sun is from our earth, and yet as numerous as the sand on the sea-shore. And had not the microscope been invented, our little ciliated polypes might have lived and died till time was no more, without one human being ever dreaming that they were living creatures, or, at all events, without one human eye living capable of seeing a structure which, when seen by lenticular aid, constrains us to exclaim, How beautiful! how wonderful!

There are various kinds of ciliated polypes; but we mean to confine our attention to that section of them to which Lamarck has given the name of Vorticella, and only to a few of these, for he has described no less than twenty-eight species. According to his description, they are very minute, gelatinous, and transparent, having no tentacula, but having around the mouth cilia, which do not lay hold of their prey, but which, by an oscillating or rotatory motion of inexpressible rapidity, cause the water containing the ani- 
malcules on which they feed to enter their mouth as a little whirlpool or vortex, and hence the diminutive term, Vorticella.

The first that I ever observed was one of the most beautiful and most conspicuous of them-the arborescent Vorticella. I had brought from a pond a handfull of aquatic plants, and having put them into a vase with fresh-rvater, I soon found, as I expected, that I had made several green Hydras prisoners. While I was watching their movements, I observed a sudden jerk in something that had been too small to attract my attention so long as it remained motionless. Fixing my eye on it, it increased in size, and having remained motionless for a little, by another sudden jerk it became so small that it was almost invisible. Having watched these changes for some time, I saw that it had life, and bringing it near to the side of the glass, and employing a pretty powerful lens, I saw that what to the naked eye had seemed a little transparent haze, was a beautiful little creature, unlike anything I had ever observed before. It was in the form of a little crystal shrub, the branches of which were dichotomously divided, every branch terminating in what resembled a little bell-shaped flower. Further observations led me to know that the sudden changes of size 
were effected by a beautiful peculiarity of organization,that the stem and the branches, finer than the thread of a spider's web, were not straight, but spiral, like the springs formed of spiral wires; that it could coil and uncoil these elastic springs at pleasure; that it rose to its full dimensions when seeking its food; and that when the rough wave conveying some rougher substance was passing over it, I conjectured that it might be consulting its safety by shrinking almost into nothing, as brave soldiers show their wisdom by falling flat on the battle-field when cannon-balls and grape-shot are passing over them, that when the enemy have wasted their strength, they may rise and rush upon them.

We have already mentioned that the lips of the little cups which adorn the Vorticella are furnished with cilia, which by a rapid rotatory motion cause currents full of animalcules to enter the cup, which proves to them the cup of death. Alas! for these little entities! but their day is over; they enjoyed life while it lasted; they have answered the ends of their being; their sufferings are momentary. Alas! there is a more dreadful gulf which rational creatures are commanded to shun. The currents around it hare a most absorbing influence, and it never returns what 
it has once swallowed up. " "Avoid it, pass not by it, turn from it, and pass away." The crystal cup of the Vorticella is not the only cup of death. It kills but the body: there is another cup that kills both body and soul. "Isook not on the wine when it is red, when it giveth his colour in the cup, when it moveth itself aright: at the last it biteth like a serpent, and stingeth like an adder."

The next that came under my notice was also in freshwater-Vorticella stentoria. This is quite a giant among this pigmy race, for when fully developed it measures-not half a fathom, nor half a foot, nor half an inch,-but half a line, which is the twenty-fourth part of an inch. This, as well as some others, has been separated from the Vorticella by generic name, and there is good ground for the distinction, for it is not fixed by a stem like the Vorticella proper, but is without a stem, and in shape resembles a trumpet or horn, not unlike the figure of a cornucopia. Though generally seen in a state of attachment, it can disengage itself and launch into the deep, and swim with considerable rapidity, for the numerous cilia that adorn its ample mouth act as so many paddles. When swimming, the sharp point of attachment is drawn up, so that instead of resembling a horn it is like a round-bottomed bag. The 
ciliated band round the mouth is somewhat spiral, giving additional elegance to its appearance; and it may be useful as well as elegant, acting probably as a purse-string; and woe to the little monads on whom that devouring purse closes,-there is no escape. The Stentors are of different colours, some red, others green or blue, and some of them have the body as well as the mouth garnished with cilia, doubtless to increase their powers of locomotion.

The Torticella that next came under my notice was a very minute, but I am persuaded, a very common one, though from its diminutive size very seldom observed. In the month of October I placed a tumbler of sea-water, in which there were some Nudibranchs, in a dark closet, not by way of punishment as naughty children, but because, being in the habit of living under stones, they cannot long bear the full light of day. Having made the observations I wished on the Nudibranchs, I returned them to the deep, and set the tumbler with the water in it on the mantel-piece. After some time I observed little dim specks on the inside of the glass, and applying to them a powerful lens, to my surprise I found that these almost invisible dots were replete with life and beauty. From the centre from twelre to twenty crystalline filaments arose with a graceful bend, each termi- 
nating in a ciliated cup, thus forming an elegant little branched Vorticella. It differed from the one I first mentioned, not only by being much more minute and more fastigiate, the first being rather dichotomous and the terminating cells placed at different heights, but also as being less lively, not having the habit of suddenly collapsing, but continuing in an unfolded state. "Vorticella, in general, can bend and turn and twist in all directions ; they can almost cast a knot on their tender and delicate stems. Microscopic shrubs composed of similar animals, hundreds of campanulate Hydre terminating their extremities, while at their highest enjoyment of full expansion in some favourable position, will suddenly collapse on a momentary alarm, crouching close down to its root in absolute quiescence. Then, as if relieved from the apprehension of danger, they rịse again to display their beautiful proportions."

What struck me as remarkable in this "minim," was, that it seemed indifferent as to its element, whether fresh or salt water; for having kept fresh-water in a tumbler for some weeks, I was surprised to find the Vorticelle as numerous in it as in the sea-water. To all appearance they were the same species, and yet had they been examined with a microscope of higher power, a difference might have been 
evident. Or had I, by way of experiment, changed the water, it might to them have been fatal, for fresh-water might have been death to the child of the briny waves, and sea-water might have poisoned the offspring of the fountains of water. Since I wrote the above, my doubts have been removed by my chancing to light on a passage in the valuable work of the late Sir J. Graham Dalyell, who, by a long-continued course of experiments and observations, was so remarkably well acquainted with the nature and habits of our Scottish polypes. He says, "Purity of the element in which zoophytes dwell, seems more essential than sustenance. Slight contamination is frequently fatal after the briefest interval. Neither can fresh or salted water be substituted for each other with impunity." From this we may conclude that the Vorticelle in the fresh and the salt water were different species, though by the aid of a Codington lens I could not detect the minute distinctions.

The same author says, "Tentaculated zoophytes are aniinated products, simple or compound, resembling the form and the eflorescence of plants. They constitute an immense proportion of the organic world, that which has received the smallest share of notice, and which is, perhaps, the least understood. It is only now that a ray of light begins to break 
upon them, disclosing their admirable beauty, their strange peculiarities, and unexampled properties, all calculated to astonish mankind with yet another work flowing from the stupendous design of the universe. As if appalled by the difficulty of the task, by the nicety of investigation, by the obscurities hovering over their theme, naturalists seem, with almost common consent, to have shrunk from it; for the most part merely skirting the boundaries-seldom advancing further, with few exceptions, than simply specifying such external characters as are most obvious to the view, and often content with hasty inspection of some mutilated or depauperated specimen. Thence much was left undone, and, till recent years, a great preponderance of results deduced from such subjects as were never seen alive, in a perfect state, or amidst their native element." And again, "To bring the vast multitude the nearer human comprehension, we endeavour to concentrate certain portions within a narrower circle by such subdivisions as to our faculties include those individuals allied by external or internal form and habits." In systematic arrangements external resemblance was long too much regarded. In conchology, similarity of the shells was chiefly attended, while the inhabitants of the shells were greatly overlooked. So also in Zoophytes, by many 
in former times the living subjects were seldom studied, or even beheld, while dried specimens, showing only the skeleton, were allowed too much to influence the arrangement. The inorganic parts were made the basis of definition, while the figure and properties of the dead and shrivelled occupants were scarcely thought of. We find Dr. John Fleming lamenting this and doing much to correct it. And in reference to that branch of natural science to which our attention is at present turned, Sir J. Graham Dalyell also says, "Dr. George Johnston, in a comprehensive and excellent work on the subject, has gone far to rectify this defect by arranging the zoophytes with due attention to the nature of the animals belonging to them. That author is entitled to the greater merit from the labour and difficulty of accomplishing such a task, for it has exacted equal skill and industry."

To Dr. Fleming and Dr. Johnston I am chiefly indebted for any knowledge I have of zoophytes. The latter of these gentlemen has written more recently, and I shall adopt his arrangement.

Zoophytes, Dr. Johnston states, are referable to two of the primary divisions of the animal kingdom-the Radiate, and the Molluscan,-and consequently constitute two classes 
distinguished by a very remarkable dissimilarity of organization. These classes have been named Anтнozos and PolyzoA, and may shortly characterized thus :-

Class I. Axthozon.-Body tending to globular, contractile in every part, symmetrical : mouth and vent one: gemmiparous, and oviparous.

Class II. Polyzon.-Body elongate, syphonal, non-contractile, and unsymmetrical: mouth and anus separate: oviparous.

Class Anthozon, Elhenberg.

The Anthozoa are divisible into the following orders:-

I. Hydroida.-Polypes compound, rarely single and naked; the mouth encircled with roughish filiform tentacula; stomach without proper parietes; intestine 0 ; anus 0 ; reproductive gemmules pullulating from the body and naked, or contained in external vesicles. Polypidoms horny, fistular, more or less phytoidal, external.

II. Asteroida.-Polypes compound, the mouth encircled with eight fringed tentacula; stomach membranous, with dependent intestinal appendages; intestine 0 ; anus 0 ; ovules produced interiorly. Polype-mass variable in form, free or permanently attached, carnose, 
generally strengthened with a horny or calcareous axis, enveloped with the gelatinous or creto-gelatinous crust, in which the polypes are immersed, and which open on the surface in a starred fashion with eight rays.

III. Helianthoida.-Polypes single, free, or permanently attached, fleshy, naked, or encrusted with a calcareous polypidom, the upper surface of which is erossed with radiating lamellæ; mouth encircled with tubulous tentacula ; stomach membranous, plaited ; intestine 0; anus 0 ; oviparous; the ovaries intermal. 


\section{CHAPTER III.}

\section{ANTHOZOA HYDROIDA.}

"The ocean with its brightness, its blue-green,

Its ships, its rocks, its cares, its hopes, its fears,

Its voice mysterious, which whoso hears

Must think on what will be, or what has been."

"Type of the Infinite! I look away

Over thy billows, and I cannot stay

My thought upon a resting-place, or make

A shore beyond my vision where they break;

But on my spirit stretches till 'tis pain

To think; then rests, and then puts forth again :

Thou hold'st me by a spell; and on thy beach

I feel all soul; and thoughts unmeasured reach

Far back beyond all date."

Dr. Johnston arranges the British species of Anthozod HyDrorda under the following tribes, families, and genera:* Ovisacs or bulbules naked, bud-like, pullulating from the bases of the tentacula. Tubularina. 
Family I. Polypes naked, or with only a rudimentary polypidom. Corynide.

+ Polypes naked.

The tentacula seattered. Cuava.

The tentacula in one row. Hydractivia.

十† Polypes with a horny cuticle.

The tentacula with globose tips. Corrse.

The tentacula filiform. Condyophora.

Family II. Polypidom fistular; the tentacula whorled.

Tubulariadie.

+ The tentacula in a single whorl. Eudexdrium.

t十 The tentacula in a double whorl.

Polypidom rooted. Tubularia.

Polypidom unrooted. Corymorpha.

* Ovisacs in the form of horny capsules or vesicles scattercd on the polypidoms, and deciduous. SertulaRiva, Ehrenberg.

Family III. Cells of the polypes sessile. Sertulariadie.

+ Cells biserial.

Cells alternate, tubular. Halecium.

Cells rasiform, cverted. Sertularia.

Cells conico-tubular, appressed. Thuiaria.

†† Cells uniserial. 
The branchlets plumose or pectinate. PlumuLARIA.

The branchlets whorled. Antennularia.

Family IV. Polype-cells on ringed stalks. CaupanuLARIAD正.

Cells alternate, campanulate. Laomedea.

Cells irregular or whorled. Campanularia.

*** Polypes propagating by buds and ova, which develope themselves on and in the body of the parent. Hydrisa, Ehrenberg.

Family V. Hydraide.

One genus only-Hrdra.

"Involved in sea-wrack, here you find a race Which Science, doubting, knows not where to place;

On shell or stone is dropp'd the embryo seed, And quickly vegetates a vital breed."

Crabbe seems to have observed these little marine animals with the eye, not only of a poet, but also of a naturalist. Before entering on the description of the individuals, it may not be improper to give some preliminary remarks on hydroid zoophytes in general. They differ much in size according 
to their species, some being a few lines and others one or two feet in height. They differ considerably also in appearance, but they are exceedingly beautiful in all their various forms; some, as they spread over the surface of a rock or a seaweed, resembling miniature marine forests, and others attached, it may be to a shell, and gracefully waving like elegant feathers. With a single exception, afterwards to be mentioned, they are all inhabitants of the sea, growing on rucks, shells, seaweeds, crabs, corallines, etc. Several of them that are of considerable height grow erect, but they are so flexible that they sustain no injury from being tossed and agitated by the waves. The oak which will not bend may be uprooted by the storm: the feathery grass may be laid level with the earth, but it rises when the blast is over. The flexible zoophyte not only outlives the buffeting of the billows, but by its graceful convolutions seems to wanton in the storm. How great the wisdom in suiting the structure to the frequent commotions of the watery element! How great the mercy when by the inworking of grace the Christian can say, "God is our refuge and strength, a very present help in trouble; therefore will not we fear, though the earth be removed, and though the mountains be carried into the midst of the sea; though the waters thereof roar 
and be troubled, though the mountains shake with the swell. ing thereof." "Troubled on every side, yet not distressed; perplexed, but not in despair; persecuted, but not forsaken ; cast down, but not destroyed."

Some of those zoophytes which, when matured, successfully combat the raves, cling to the rock when they are young and tender, creeping along its surface. He who made them teaches them thus instinctively to consult their safety. And He who cares for the infant zoophytes, much more cares for the lambs of his flock, gathering them with his arm, and carrying them in his bosom. Oh! let them cleave to him in the season of youth, and then, being rooted and grounded and stablished in the faith, should days of darkness and of danger come, he will either hide them in the hollow of his hand, or should he call them to the hottest of the fight in the high places of the field, he will fit them for the conflict, and make them even more than conquerors.

Some of the hydroid zoophytes are unclothed, but most of them have their bodies invested in a horny sheath, which is called the polypidom, i.e. the house of the polypes. They differ much in form, but there is great beauty in all the varieties of their structure as well as of the sculpture of cells and resicles. They are generally branched and jointed, 
but the joints are without hinges. The stem and branches are of the same material. Along the sides or at the upper extremities of the branches we find the cup-like cells of the polypes. Intermingled with the cells there are other vessels, called vesicles, formed of the same material as the cells, but widely distinguished from them by their larger size and by their different shape. Those vesicles contain the ovules from which another generation of polypes is to spring.

The polypidoms, when dried, are generally of a yellowishhorny colour. The substance of which they are formed seems analogous to horn. In a young state it adheres in some degree to the pulpy substance of the animal, but it afterwards become detached in consequence of its shrivelling, and also in consequence of the movements of the animal that it contains. Some distinguished naturalists argue that this horny sheath is vascular and organized, and conclude from this that the polypidom has a growth of its own independent of the animal that inhabits it. But other naturalists, no less distinguished, maintain, and apparently with greater truth, that there is but one life and one plan of development in the whole mass, and that this depends, not on the polypi, which often fall off, as in Tubularia, but on the 
general fleshy substance of the body. The growth of the polypidom is dependent on the growth of the pulp, or rather they grow together, as the feathers, beak, and claws increase in size on a young growing bird.

Careful observations have been made on the polypidom, with its included pulpy matter, and the result is as follows. The ovule, when matured, drops from the vesicle, and fixes on some rock, or searveed, or shell, or sometimes even on some other marine animal, such as an Ascidia. Minute fibres, proceeding from its under side, cause it to adhere, while from the upper side the commencement of the stem springs up. The structure of this shoot is at first homogeneous: gradually, however, the pulp is formed in the inner part, and the shoot, having assumed a bulbous form at the summit, condenses and expands, and so does the horny covering, till one or more closed cells are formed. By and by, little knobs protrude from the cells, and increase till they become tentacula, when the cell opens and the animal begins to catch its prey; and from that moment it is as large as ever it is at any subsequent period. But though the polypes increase not in size, they increase in number; for, as the newly-formed one is constantly obtaining nourishment, the central pulp increases and shoots 
upwards, forming.additional cells, till the polypidom has attained its usual size.

The polypes, with the exception of the Tubularina, can retreat within their cells, hiding themselves from danger. Their body is very contractile, and can change rapidly from a cylindrical to a globular, or from a globular to a cylindrical form. The tentacula, which are irregular in number, can be extended to a great length, or can instantly contract into little knobs, shrinking within the cell. In the centre of the circle formed by the tentacula is the mouth of the polype, pouting upwards, and ready to receive whatever prey the prehensile tentacula from time to time bring to it.

The hydroid zoophytes increase by buds or eggs. When the increase is by buds, it may be said to be a perpetuation of the same individual animal, as a plant perpetuated by a layer. When it is by eggs, new individual animals of the same species are produced. Every species begins its existence by a single polype, which grows up to a polypidom, containing, it may be, hundreds of polypes. Darwin, in lis 'Temple of Nature,' thus sings :-

"New buds and bulbs the living fibre shoots

On lengthening branches and protruding roots;

Or, on the father's side, from bursting glands

The adheriug young its naseent form expauds : 
In branching lines the parent trunk adorns, And parts ere long like plumage, hairs, or horns."

There are several kinds of eggs from which young animals spring. There are what have been called motive buds produced in the ovisacs. These are found in the Tubularina like little clusters of grapes, growing from the bases of the tentacula. Sir J. G. Dalyell, in the 'Edinburgh New Philosophical Journal,' in his observations on Tubularia indivisa, states, that as soon as the bulb had fallen from its crested head, slight prominences, enlarged at the tips, pullulate from the under surface, and the "nascent animal," elevating itself on these rudiments of the tentacula, as on so many feet, enjoys the faculty of locomotion. "Apparently selecting a site, it reverses itself to the natural position, with the tentacula upwards, and is then rooted permanently by a prominence, which is the incipient stalk, originating from the under part of the head. Gradual elevation of the stalk afterwards continues to raise the head, and the formation of the zoophyte is perfected." In writing respecting Laomedea dichotoma, he says that the vesicles, which are seldom produced, contain from twenty to thirty greyish corpuscula, with a dark central nucleus. At first, all are immature and quiescent, but motion at length commences : the corpuscula 
become more distinct; several slender arms protrude from the orifice of the vesicle, which are seen in veliement action; and after many struggles, an animated being escapes. But this has no relation either to the planula of the Sertularia or the corpusculum of the Flustra, Alcyonium, or Actinia. It might be rather associated with the Mechusaria. Before ascertaining its origin, I had named it Animalculum tintinnabulum, from its general resemblance to a common hand-bell, for the purpose of recognition. This creature is whitish, tending to transparency, about half a line in diameter; the body is like a deep watch-glass, surmounted by a crest rising from the centre, and fringed by about twenty-three tentacula pendent from the lip belor. These are of muricate structure, or rough, and connected to the lip by a ball twice their own diameter. The summit of the crest unfolds occasionally into four leaves, and four organs prominent on the convexity of the body appear at the base. When free, the animal swims by jerks or leaps through the water, or drops gently downmards; it is incited to move by the light, and it has survived at least eight days. Then it disappears; at least, I have not been able to pursue its history longer. No other product has ever issued from the vesicles of the Sertularia dichotoma." 
Sir J. G. Dalyell, in his most valuable work on "the rare and remarkable animals of Scotland," follows out at greater length his observations recorded in the "New Philosophical Journal.' "Nothing," he observes, "can be more remarkable to the spectator than finding the progeny free while the parent is immoveably fixed-sufficient evidence that there is nothing of vegetable nature in such zoophytes. It is as strictly an animal product as an Alcyonium or an Ascidia, whose original corpusculum, planula, spinula, larva (by whatever name it may be called), which by nature becomes riveted to some solid sustaining foundation. The nascent Tubularia thus formed, and capable of selecting its position, loses that faculty never to be regained, and is rooted at an indefinite period-sometimes in the course of one day, sometimes on the lapse of two. But quiescence is essential here. Should frequent disturbance alter its place, the adhesive power seems to be impaired, or the creature rendered incapable of its exercise. The movement of those that are rooted in early age is commonly much more rapid than that of others. Specimens discharged from the cyst on the 1st of January, and affixing speedily, were about four lines high in seven days. Those whose adhesion had not ensued were infinitely smaller. With the latter it is not improbable that, instead of 
the softer extremities vegetating downwards, and remaining susceptible of adhesion, it becomes invested by exposure with an imperceptible epidermis. All nascent Tulularice are of the palest grey; and for the first fortnight the length of the tentacula, and general dimensions of the hydra, are proportionally greater than in adults. But the stem is seldom straight; sometimes also irregularities are seen near the root, which has no radicles. The head of the nascent Tubularia falls after an indefinite period, just as with the adult. But life is so feeble here, that the first is rarely replaced by a successor." After several other interesting observations, which our limited space will not allow us to quote, he adds - We collect from the preceding detail that an external ovarium is situated among the other parts composing the hyrdra or head of the Tubularia inrlivisa; - that the unusual curvature of the tentacula, their irregularity, and symptoms of approaching decay, augment in proportion to its advancing maturity, while the aspect of the stomach also indicates that its functions are required no longer. It is impossible to overlook the correspondence of these conspicuous facts with that uniform principle of nature, obviously testifying a warmer solicitude for perpetuation of the progeny than for the permanence of the parent. How few are the effectual 
provisions for warding off a mortal blow from the strongest or the weakest of animated beings! How numerous the cares and precautions that others shall exist! How infinite are the means of destroying life! The elements themselves seem to conspire against it. Myriads which have lived perish in a moment; while this lapse of time is demanded for their evolution and maturity;-yet Nature forbids extirpation of their race. Whence utter destruction is counteracted, and inevitable fate compensated by multiplication." Still further, the veteran naturalist subjoins-"Throughout animal nature there is not a subject better adapted for profound contemplation, or which can excite greater admiration, than the enclosure of a germ, susceptible of life and evolution as a perfect being, in an egg. What device alike suitable could have been contrived as adapting a point,-that which has no parts and no magnitude,- to carry on successive generations, accompanying the infinite course of time! Let the mind wander over the boundless extent of the animal kingdom;-let our sight behold the varied, the endless, the indescribable forms comprising life-as if exhausting every combination of matter; astonishment bewilders our conceptions of the transcendent Power which could fashion them into definite shapes. It 
seems as if some ancient world were shivered, that breath might be infused into every fragment."

The power that hydroid zoophytes, as well as not a few other marine animals, have of emitting phosphorescent light, is a rery remarkable property. It has now been observed by many, and is well deserving of even more attention than it has yet received.

\author{
"The luminous life \\ That makes the dark nocturnal ocean bright \\ With constellated clusters of rare things \\ Group'd or apart; seeming in lustrous grace, \\ Fantastic wreaths of many-coloured gems \\ Instinct with living fire:-or here and there \\ Glittering in golden glory :-flashing forth \\ Metallic white-or tremulous silver cinqued \\ By ambient tints of sapphire, pink, and blue; \\ As if some opulent spirit of the sea \\ Had from his treasury of prceious stones, \\ Flung up his choicest treasures on the waves \\ To bathe their beauties in the meek moonshine."
}

This comprehends the various luminous bodies that enlighten the dark deep sea. Crabbe's Muse, in her evening walks by the sea-shore, had not failed to observe these beautiful marine creatures, as we may see from the following passage from 'The Borough,' which we shall quote, as it 
seems to refer more particularly to the phosphorescence of zoophytes.

"While thus with pleasing wonder yon inspect

Treasures the vulgar in their scorn reject,

See as they float along th' entangled weeds

Slowly approach upborne on bladdery heads ;

Wait till they land, and you shall then behold

The fiery sparks those tangled fronds enfold-

Myriads of living points; th' unaided eye

Can but the fire, not the form descry."

It has been questioned whether this phosphorescent fluid is a secretion of life and health, or the result of some partial decay and decomposition. Dr. Johnston thinks that this has not yet been ascertained, but seems rather disposed to favour the latter opinion. "No species," he says, "has been seen luminous in its natal site, and when undisturbed; but after being torn from their attachments, or tossed ashore or trodden upon, or carried away to the home of the experimenter, and variously irritated, then the tiny lamps shine forth momentarily, die away again, and are not relit unless some new shock or injury is given." From any experiments that I have made, I would say that the livelier and fresher they were, the more capable they were of luminosity. The Sea-pen is of the Asteroida, but I found it as 
luminous as those of the Hydroida. I had not the opportunity, indeed, of trying the experiment on it in the sea, but when quite alive in a vase of sea-water, I found that it emitted, when smartly touched, a flash of phosphorescent light. When I brought hydroid zoophytes from the sea in a close vasculum, the sea-water adhering to the seaweeds kept them as much alive during the transit, occupying less than half an hour, as if they had remained on the rocks on which the seaweeds grem, and where many of them, during every ebb-tide, are quite deserted by the sea. Taking them into a darkened room half an hour after they were removed from the rocks, I found the phosphorescent light, when they were shaken, quite brilliant. The experience of Mr. William Thompson, of Belfast, an accurate observer, seems to have been the same. He remarks, "I do not think it probable that the luminosity of zoophytes is caused by partial decay and decomposition, as I have, especially in the month of January, 1534, and frequently since, observed many species to put forth their lights vigorously a very few hours-certainly within three-after I had dredged them from the bottom of the sea. They were not sooner looked at, because it was not dark till about that time after their capture. Torn from their attachments these certainly were, but they 
were treated tenderly, and placed in a huge vasculum, and in it conveyed to our quarters. The zoophytes parasitic on Algæ, brought home in the same way, made their positions known by exhibiting their tender and beautiful lights." My friend, Mr. Hassall, has the following interesting remarks, in the 'Annals of Natural History,' and there states that he had ascertained that all the transparent zoophytes possess highly luminous properties. "This fact," he subjoins, "I first discovered in a specimen of Laomedea gelatinosa, and subsequently in a great variety of other species. If a portion of it, adhering to the seaweed to which it is attached, be taken from the water and agitated, a great number of bright phosphorescent sparks will be emitted; these sparks proceed from each of the denticles of the coralline containing polypi, and the phenomenon is equally apparent whether the specimen be in or out of water. I lately had an opportunity of beholding this novel and interesting sight of the phosphorescence of zoophytes to great advantage, when on board one of the Devonshire trawling-boats, which frequent this coast. The trawl was raised at midnight, and great quantities of corallines were entangled in the meshes of the network, all shining like myriads of the brightest diamonds." A still more striking 
passage I extract from another paper by the same author, in the 'Annals of Natural History.' "Numerous friends can bear witness to the exceeding brilliancy of the phosphorescent light emitted by a great variety of species, which I was frequently in the habit of exhibiting to them. Once a week I received from the master of a trawling-vessel on the Dublin coast, a large hamper of zoophytes in a recent state; in the evening these were taken into a darkened room, and the spectators assembled; I then used to gather up with my hands as much of the contents of the hamper as I could manage, and tossing them about in all directions, thousands of little stars shone out brightly from the obscurity, exhibiting a spectacle, the beauty of which to be appreciated must be seen, and one which it has been the lot of but few persons yet to look upon. Entangled among the corallines were also numerous minute luminous annelides, which added their tiny fires to the general exhibition."

Without knowing that Mr. Hassall had written on the subject, I sent a paper to the 'Annals of Natural History' about the same time, detailing some observations I had made, though I afterwards found that this phosphorescence of zoophytes was known to many more than either Mr. Hassall or I was aware of. Dr. John Fleming knew it. 
The late truly amiable Dr. Neill knew it. He told me that more than twenty years before that period, having laid some zoophytes out of his vasculum in the lobby till he had time to make some experiments with them, one of his maid-servants, after it was dark, having come across them roughly, was almost frightened out of her wits by the sudden flashes, thinking that Will-o'-the-wisp had sprung up among her fingers.

As I find that I generally write more con amore on a subject when it is new to me, and when, in my ignorance, I may think that perchance it is not very familiar to others, I may, perhaps, be pardoned for transcribing a portion of what I wrote for a periodical more than ten years ago. "Having brought from the shore, in a vasculum, some zoophytes, I laid them aside till I should have leisure to examine them. When the evening came I was beginning in the dark to take them out of the vasculum, when, to my surprise and delight, they began to sparkle. Recollecting what I had read in Dr. Johnston's 'History of British Zoophytes' respecting the phosphorescence of Sertularia pumila, I gave them, as I removed them from the vasculum, a hearty shake, and they instantly became quite brilliant, like strings of little stars or precious diamonds. To ascer- 
tain which were the kinds that sparkled, it was necessary to make the selection by candle-light, and then removing the light to make the experiment. The first I tried was the pretty Talkeria cuscuta, and with it I succeeded in striking light. From Sertularia polyzonias and Cellularia reptans little light arose. With Laomedea geniculata I was very successful: on this and on other occasions, it not only, when shaken, became very sparkling, but also emitted a strong smell of phosphorus. Membranipora pilosa, var. stellulata, which spreads itself on a flat frond in a star-like form, became doubly entitled to the name of stellated, as every polype in its little cell lighted up its tiny star, so that for a short time the polypidom became a bright constellation. I tried a specimen of Sertularia pumila, respecting which Stewart, as quoted by Dr. Johnston, says, "If a leaf of Fucus serratus, with the Sertularia upon it, receirc a smart stroke with a stick in the dark, the whole coralline is most beautifully illuminated, every denticle seeming to be on fire;" but as my specimen had lain too long on the shore, it did not shine, the polypes, I suppose, being dead in their cells. Flustra membranacea, however, was very beautiful. When the seaweed on which, like silver-lace, it had spread, was shaken or bent,-as the cells 
were closely arranged, it was instantly in a blaze, and became for a little like a sheet of fire.

Some time afterwards, I repeated the experiment with several other zoophytes. I got some specimens of the elegant feather-like Plumularia cristata, but they had lain too long exposed to the ungenial influences of a November sky, so that only a few of the polypes lighted up their tiny lamps, and their light was feeble and of a darker red than any I had seen exhibited. Having got a compound Ascidia attached to a seaweed, when I shook it roughly in the dark, I had the satisiaction of seeing that it was as much disposed as any of the zoophytes to resent the insult. Though beautifully marked with star-like figures, it sent not forth a sparkling light as might have been expected from these rows of stars, but the whole massy body of the creature became at once in a glow, shining, however, with a more lurid and sullen-looking fire.

We are naturally led to inquire why the benign Creator, who does nothing in vain, has granted to so many of the feeble inhabitants of the deep, the power, in certain circumstances, of becoming luminous. As He made all things for His own glory, and as His inanimate and irrational creatures glorify Him, by furnishing to His rational and intelligent 
creatures topics of devout contemplation, fitted to fill them with wonder, and to lead them to show forth His glory and praise, we doubt not that the luminosity of these marine "minims" was intended to be one of those topics of contemplation. "Praise him, ye dragons and all deeps," says the Psalmist,-or, "all inhabitants of the deeps." The elegant zoophytes, and the jelly-like Medusa, which abound so much in the deep, are well calculated to show forth His praise during the day; and should not our pious admiration be increased, when the former, on being handled during the night, become more brilliant than rubies; and when the latter, though often, from their pellucidity, invisible through the day, render, in the darkness, every troubled portion of the deep a splendid whirlpool of innocuous fire?

But should not we still more adore his wonder-working hand, if we find that what is beautiful in our eyes is highly beneficial to the floating torch-bearers themselves? May not this garment of fire be their armour of defence,-their panoply of protection? They have their enemies amidst the waves; and may not this sudden flash of fire in the darkness of the deep be intended to alarm the foes by which they are assailed? The Lord was to his people of old a pillar of fire by night, and a pillar of cloud by day. By fire and 
cloud he may deign to protect his irrational creatures in the present day. When the cuttle-fish is pursued by its enemies, it can eject an inky fluid from a bag with which it is furnished, so that, involved in a murky cloud of atramentous water, it is concealed from the grasp of its voracious foes. The Ascidia which we mentioned, seems inert and defenceless, and would be a very savoury mouthfull to a prowling haddock; but if, when the gourmand begins to nibble its prey, it on a sudden became like a live coal, we suspect that the boldest haddock would stand aghast. If He thus defend with a robe of fire this helpless inhabitant of the deep, how much more will $\mathrm{He}$, according to His promise, be "a wall of fire around his people and the glory in the midst of them."

And when is it that these tiny dwellers in the deep appear in greatest splendour? It is in troublous times-in the darksome hour of danger. And is it not under the cloud of aflliction and in the dark night of distress that God's chosen people most sweetly shine? Is not the brightest page of their history that which tells how " they wandered about in mountains, and dens, and caves of the earth, not accepting deliverance, that they might obtain a better resurrection"? And if they shone in that hour of darkness, it was as the moon when she looks on the orb of day,-it was be- 
cause from the midnight gloom in which they were involved, they looked up to the Sun of Righteousness, and shone with reflected radiance, when cheered by his gladdening rays!"

Afloat upon the deep at midnight hour,

When sleep has sealed the eyes of all aboard;

When even the helmsman, trusting to the calm,

Over the rudder sleeps; when not a sound,

Save at loug intervals the heavy elank

Of the dark wave, is heard against the keel-

Thy pensive mind inclines to ruminate;

$\Lambda$ nd 'midst thy ponderings perchauce thou'lt say,

'All nature sleeps! Hail, solitude sublime!'

But sleepeth nature? Sleep these twinkling orbs?

And reigneth solitude? Art thou forsooth alone?

Hover no cherubim on noiseless wing

Around thy head? Dead is the silent sea?

Smite but with sudden stroke the darkened prow,

And flash refulgent from the gloomy deep

Will tell that myriads of the finny tribes,

In silver shoals, are wantoning around.

Dip but an oar into the briny main,

And straight the oar drops diamonds, and the sea,

Though, when unwounded and untroubled, dark,

Now shines like furnace full of molten gold.

'Tis with vast multitudes of living things

That thus the deep is burnish'd. Undisturb'd,

No light they give, and would unseen remain,

Though the bright sun shone on the peopled wave.

But in the gloom of night, if the rough wind, 
Or ruder hand of man, turmoil excite

Throughout their briny realm, then brightly shine

These ocean gems, these glow-worms of the deep.-D. $L$.

I shall now close these preliminary observations with an extract from a letter from my kind friend Mr. Wigham, of Norwich, received at the very time I was writing them, though he knew not that I was so engaged.

"In September we had a prodigious quantity of Flustra membranacea and Laomedea geniculata on the Norfolk coast, and, probably, on all the east coast, as I saw remains of them in Essex in the latter end of the month. The Flustra I had never gathered before. There were waggon-loads of it, chiefly on Fucus vesiculosus and Fucus nodosus. The Laomedea was on everything,-old branches of trees, cuttings of firdeals, chips, etc.; and a piece of very hard cinder as big as my fist was quite covered with it, and so beautifully phosphorescent, that long after it was dark I was strolling about the beach at Cromer, stirring them up, and admiring their surpassing beauty. The sea was beautifully luminous that evening also, and I certainly thought that the zoophytes being so very numerous would very well account for it, as there must have been many billions of them in the water." 
"Hail to thy face and odours, glorious Sea! 'Twere thanklessness in me to bless thee not, Great being! in whose breath and smile My heart beats calmer, and my very mind Inhales salubrious thoughts. How welcomer Thy murmurs than the murmurs of the world! Though like the world thou fluetuatest, thy din To me is peace, thy restlessness repose. E'en gladly I exchange yon spring-green lanes With all the darling field-flowers in their prime, And gardens haunted by the nightingale's Long trills, and gushing ecstasies of song, For these wild headlands, and the sea-mew's clang.

"The spirit of the universe in thee Is visible, thou hast in thee the lifeThe eternal, graceful, and majestic life Of nature: and the natural human heart

Is therefore bound to thee with holy love." - Campbell. 


\section{Class I. ANTHOZOA.}

"The study of Natural History is within the reach of every one; and he who is engaged in it, is presented at every step in his progress with some. thing capable of awakening pleasing emotions. The whole earth is to him a vast museum, in which are crowded beautiful and sublime objects, animate and inanimate, in almost endless variety, all combining to amuse the understanding and gladden the heart."

\section{ANTHOZOA HYDROIDA. \\ Tribe I. TUBULARINA. Family CORYNIDA.}

Character. Polypes rooted, fleshy, or sheathed in a horny skin, simple or ramose, the upper part dilated into a clavated head armed with tentacula, which are either irregular or sub-biserial, and are variable in number; mouth terminal; oviform capsules pullulating in clusters from the bases of the tentacula, and naked.

\section{Genus I. CLAVA, Gmelin.}

Generic Character. Polypes single, fleshy, more or less clubheaded, but contractile, and mutable in form; the tentacula scattered, smooth, filiform, varying in number; mouth terminal and naked. The name is from clava, a club.-Jolnston. 


\section{Clava multicornis, P. S. Pallas*.}

Hab. Parasitical on seaweeds, corallines, etc., between tide-marks; Harwich, Pallas. Not uncommon. The polypes are gregarious, about half an inch in height, with a knobbed, rose-coloured, fleshy head, with scattered filiform tentacula, which the creature can elongate at will, though not so much as the Hydra. Dr. Coldstream says, that after being kept in sea-water for some hours, some of the animals protrude the inner surface of the mouth so as to present a convex disc, with the tentacula ranged round it.

\section{Genus II. HYDRACTINIA, Van Beneden.}

Gen. Char. Polypes naked, gregarious, united on a common crustaceous base; tentacula in one subalternating circle; eggs or bulbules sessile, clustered on untentaculated individuals.Johnston.

1. Hydractivia echivata, G. Montagu. (Plate I. fig. 1.)

Hab. On old univalve shells, from deep water. Not uncommon.

* The name affixed to the speeific character by Dr. Johnston, is that of the person who, so far as he could asecrtain the fact, has added the speeies to the British fauna. Pallas was born in Berlin. 


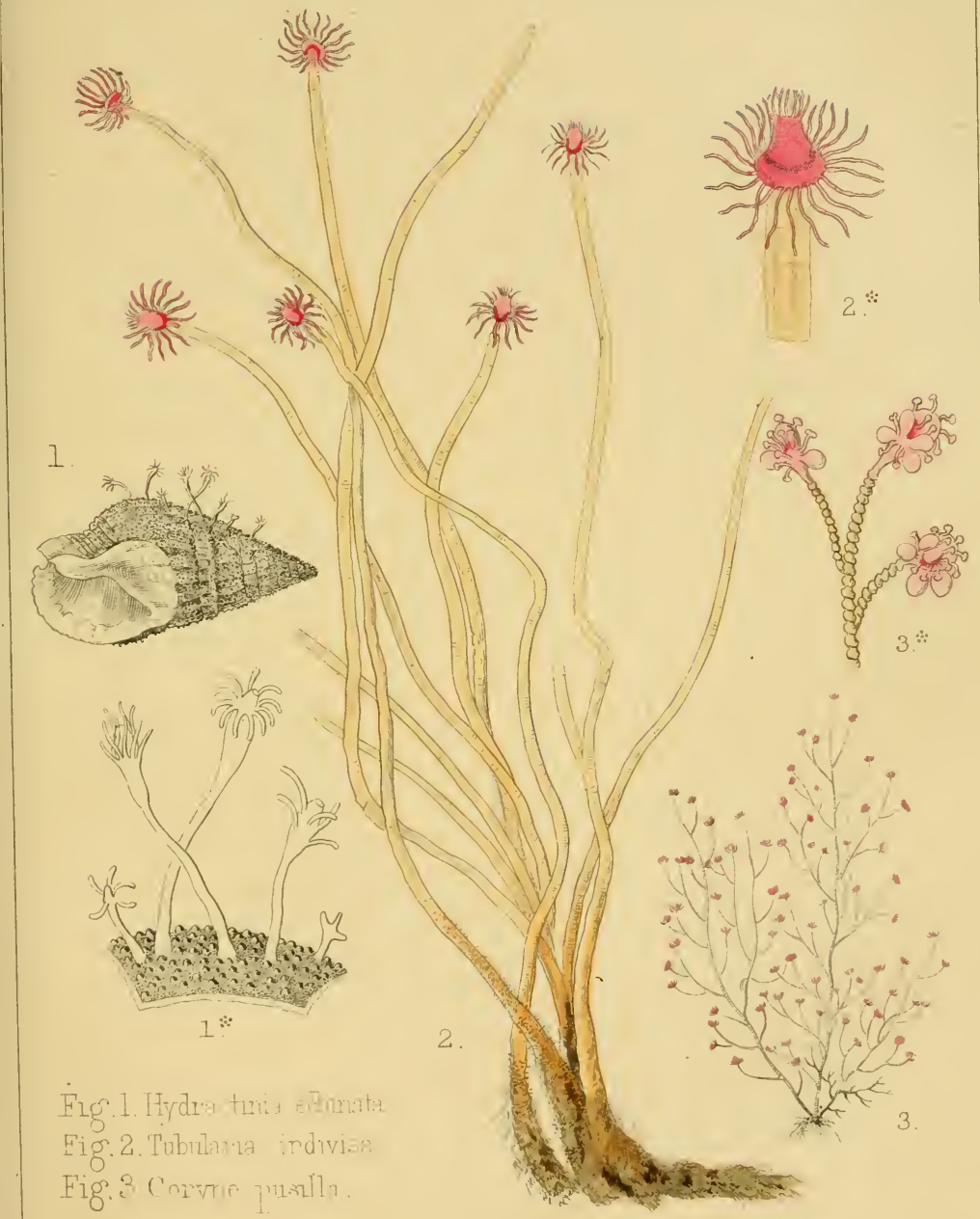



CORYNE.

This is not unfrequently found cast ashore on the Ayrshire coast, and I have dredged it in Arran. It was first known to me under the name of Alcyonium echinatum. The shells on which it is generally found by us are, Buccinum undatum, Fusus corneus, Natica glaucina, and Nassa reticulata. It has been stated by several naturalists, that the shells it infests are inhabited by hermit crabs, and some of them have observed, as we also have done, that the rim of the aperture of the shell is extended by the growth of the zoophyte in the form of a horny membrane, by which the dimensions of the crab's domicile is greatly enlarged, having thus a kind of verandah, without an intervening wall.

\section{Genus III. CORYNE, Gertner.}

Gen. Char. Polypes sheathed in a thin horny membrane or tube, branched and subphytoidal, the apices of the branches polypous, clubbed, and furnished with short tentacula with globular tips, and arranged without order; mouth terminal; ovules separate, very shortly pedicled.-Johnston.-This name is the same in meaning as that of Genus I., clava being the Latin, and coryne the Greek, for a club.

1. Coryne pusilla, Gartner* (Plate I. fig. 2.)

* Joseph Gærtner, M.D., born in Wirtemberg, 1732. 
Hab. On seaweeds, and stones between tide-marks.

This little zoophyte is not often met with on the Ayrshire coast, but being minute it may at times escape notice. It creeps along the surface of the object to which it adheres, seldom more than an inch in height, tubular, horny, subpellucid, wrinkled, and more or less ringed. The head is of a reddish colour. It can bend its head, or give to any tentaculum a distinct motion and direction, though its motions are slow. I have specimens of it from Mrs. Griffiths, Torquay; Miss Cutler, Budleigh Salterton; Mr. Tumanowicz, Hastings; and Mrs. Gatty, from the Yorkshire coast.

Small as this creature is, it is one respecting which there is much difference of opinion among naturalists. Four varieties of it are described by Dr. Johnston.

\section{Genus IV. CORDYLOPHORA, Allman.}

Gen. Char. Polypidom horny, branched, rooted by a creeping tubular fibre, branches tubular. Polypes developed at the extremities of the branches, ovoid, bearing the mouth at the distal extremity, and furnished with scattered filiform tentacula. -Allman.-The name is from two Greek words, the one signifying a water-newt, and the other a burden. 
1. Cordylophora lacustris, G. J. Allman*.

Hab. Dock of the Grand Canal, Dublin, Allman.

The dock is free from any admixture of sea-water, and the Professor kept it alive for a fortnight in fresh-water, not taken from the dock. It was found on the bottom of an old canal-boat. It is horny; branches cylindrical. Polypes at the end of the branches, ovoid, and prolonged into a conical projection with the mouth at the extremity; the body of the polype being covered with scattered, filiform tentacula.

\section{Family TUBULARIAD无.}

Character. Polypidom plant-like, horny, rooted by fibres, rarely free, simple or branched, tubular, filled with a semifluid organic pulp. Polypes naked, protruded from the ends of the tubes, and not retractile, fleshy and red, armed with one or two circles of smooth filiform tentacula. Bulbules pullulating from the bases of the tentacula, soft and naked. Embryo medusiform. - Johnston.

\section{Genus V. EUDENDRIUM, Ehrenberg.}

Gen. Char. Polypidom rooted by creeping fibres, erect and * The distinguished Professor of Botauy, Trinity College, Dublin. 
variously branched, the fibres cylindrical, tubular, filled with a soft pulp. Polypes hanging from the extremity of every branchlet, non-retractile, roundish, somewhat pedicled, naked and fleshy, the body encircled with a zone of filiform tentacula; the mouth central and subtubular.-Jolinston.-Name from two Greek words signifying well, and a tree.

\section{Eudexdrium rameuns. (Plate II. fig. 5.)}

Hab. On shells and stones, deep water. Shetland and Leith, Dr. Coldstream; Bay of Whitburn, Miss Dale; Northumberland and Berwickshire, frequent, Dr. Johnston; Scarborough, Mr. Bean; Whitehaven, Mr. W. Thompson ; Dublin Bay, Mr. Hassall; Cornwall, Mr. Couch ; Aberdeenshire, Mr. Macgillivray; near Liverpool, Mr. Riylands.

Dr. Johnston very truly says, "This animal production so perfectly resembles a tree in miniature deprived of its leaves, that persons unacquainted with the nature of zoophytes cannot be persuaded that it is not of a vegetable nature." It is from three to six inches high. It is irregularly divided into many compound branches. The polypes are of a reddish colour, the tentacula whitish and numerous.

This zoophyte has not been found on the Ayrshire coast. We have fine specimens from Mr. Tudor, Bootle. It is well 
figured in Dr. Johnston's excellent work, in plate v. 1, 2, and also at p. 407. It seems to have been a special favourite of the late Sir J. G. Dalyell, and he gives splendid figures of it in his great work, in plate vi. and plate vii. It is a pleasure, also, to quote part of his enthusiastic description. "This is a splendid animal production,-one of the most singular, beautiful, and interesting among the boundless works of Nature. Sometimes it resembles an aged tree, blighted amidst the war of the elements, or withered by the deep corrosions of time: sometimes it resembles a vigorous flowering shrub in miniature, rising with a dark brown stem, and diverging into numerous boughs, branches, and twigs, terminating in so many hydræ, wherein red and yellow intermixed afford a fine contrast to the whole."

"The glowing colours of the one, and the venerable aspect of the other,-their intricate parts often laden with prolific fruit, and their numberless tenants, all highly picturesque, are equally calculated to attract our admiration to the creative power displayed throughout the universe; and to sanction the character of this product, as one of uncommon interest and beauty.

"A very fine specimen of the Tubularia ramea (Euden- 
drium rameum) was recovered from among the rocks of a cavity in the bottom of the Firth of Forth, at about 150 feet from the surface. It had vegetated in such a direction that it was detached quite entire.-Being transferred to a capacious vessel of sea-water, $I$ found it rising seven and a half inches in height, by a stem about nine lines in diameter near the root, then subdividing into several massy boughs, besides many lesser branches. Numberless twigs, terminated by thousands of minute hydræ of the palest carnation, clothed the extremities, which were ten inches apart.

"The root itself diffused irregularly, by a multitude of mossy-like fibres, which might be circumscribed by a circle of two inches diameter. It is to be observed that the stem, and the higher rigid portions, consisted of irregular bundles of tubes; but about two inches of the highest were in verticillate arrangement. Though composed of bundles of tubes below, the absolute extremities, bearing the hydræ, resolve into single tubes, each with its animal.

"Many parasites invested this splendid specimen. Masses of the pure white and deep orange Alcyonium digitatum hung from the boughs; Sertularia, sponges, and algæe were profusely interspersed, all proving, by their obvious successive generations, the great antiquity of the Eudendrium. 
"Other specimens have occurred of similar aspect and conformation, chiefly from four to six inches high, but none above nine. One beautiful and luxuriant specimen, four inches high, and diverging four inches, might have been circumscribed by an ellipse two inches and a quarter across. By gross computation, 1200 hydræ, deeper-coloured than peach-blossom, decorated this latter specimen. The head or hydra of this zoophyte is deciduous*."

" Full many a gem of purest ray serene

The dark unfathom'd depths of ocean bear;

Full many a flower is born to blush unseen, And waste its sweetuess on the desert air."

"Thy way is in the sea, and Thy paths in the great waters, and Thy footsteps are not known."

2. Eudendrium ramosum, Ellis.

Hab. Shores of Kent and Sussex, Ellis; Devon, Mrs. Griffiths; Cornwall, Mr. Couch; Scarborough, Mr. Bean; Hastings, Mr. Tumanowicz; West of Ireland, Mr. W. Thompson; near Kirkcudbright, Mr. E. B. Fleming; coast of Ayrshire, D. L.

It is from two to six inches in height, the branches slender,

* 'Rare and Remarkable Animals of Scotlaud,' by Sir John Graham Dalyell, Baronet. 
horny in colour and texture, consisting, as also the stem, of a single tube. The branches are erecto-patent. The branchlets are ringed at their origins. It is rather rare on the west coast of Scotland; but we got it on one occasion on an irony-like cinder dredged from the deep.

Ellis, who discovered it on the Kentish shore nearly a hundred years ago, says-" Here the curious naturalist may plainly discover a polype branching out like the common fresh-water IIydra, but strongly fortitied by nature to support itself in its turbulent situation; for he will observe that this is defended by a tough horny covering, and fixed by its base to solid bodies in the sea, to secure itself from the infinite number of enemies that every moment surround it."

Sir J. G. Dalyell remarks, that " faint whorls, almost imperceptible in the living product, indent the origin of the branch and the extremity of the twigs. Chestnut-brown or umber is the predominant colour of the inorganic parts; the hydra is very minute and reddish. The tentacula are susceptible of much elongation, when they become almost of cylindrical form." The neck, he adds, is so flexible, that it is susceptible of complete recurvature, or looking behind, as we would say of other animals. He has wit- 
nessed, very satisfactorily, a circulating fluid in this zoophyte. Dark particles are seen ascending one side of the neck, and descending by the other, as if conveyed by the current of a fluid. The current is chiefly visible at the lower part of the head. The rate of the current is not regular, sometimes quick and sometimes slow, and at times quite suspended-yet without evident injury.

"The provision of Nature," he subjoins, "for conducting a vivifying principle throughout the whole extent of animal organization, whereby it shall impart vigour to the remotest parts, surpasses all the admiration which mortals can bestow upon it; and this marvellous expedient is rendered still more wonderful by reflecting on the means adopted for its impregnation with atmospheric qualities, devised for the common sustentation of the universe. Everything conspires to show the grandeur of the plan from whence the world was originated."

The animal, though so flexible itself, has no power over the comparatively rigid tube it inhabits. When Sir J. G. Dalyell cut two portions from a specimen, he found them rooted to the glass in which they lay, in the course of a night. 


\section{Genus VI. TUBULARIA, Linnaus.}

Gen. Char. Polypidom horny, fixed by a creeping fibre, ereet, fistular, and unbranched, the tube filled with a semifluid medulla. Polypes placed at the extremities of the tubes, nonretractile, fleshy, furnished with two circles of filiform smooth tentacula, "one row surrounds the middle of the heads, and the other is placed round the mouth;" bulbules clustered, shortly pedieled, placed within and at the base of the lower tentacula; embryo sometimes in the form of a Beroë, sometimes of a Hydra. - Johnston. - The name from tubulus, a little pipe.

1. Tubularia indivisa, E. Lhwy $d^{*}$. (Plate I. fig. 3.)

Hab. On shells and stones from deep water; not rare. Rothesay Bay, Prof. E. Forbes; Cumbraes, D. L.

"This," says Ellis, "is the largest of this tribe of British tubulous corallines. It arises from small worm-like figures, which rise into distinct tubes five and six inches long, full of a thick reddish liquor. On the top of these the polypes appear with plumed crests. These tubes, in the dried specimens, have the resemblance of oaten pipes, that is, part of an oaten straw with the joints cut off." Te may add, however, that they are clearer and more horny than oat-

* Edward Lhwyd, or Lloyd, naturalist and antiquarian, born in Wales in 1670 , and died in 1709 . 
straws, and not so thick. They grow in clusters of thirty or forty pipes together, and certainly a dried specimen has but little beauty. How great is its beauty, however, when seen in a live state, like a rich bouquet of splendid flowers! "The yellow fistulous stem," says Sir J. G. Dalyell, "full of mucilaginous pith, is rooted on a solid substance below, and crowned by a living head resembling a fine scarlet blossom, with a double row of tentacula, and often with pendent clusters like grapes, embellished by various hues, wherein red and yellow predominate. Fifty, or even a hundred and fifty, are at times crowded together; their heads of diverse figures, shades, and dimensions, constitute a brilliant animated group, too rich in nature to be effectively portrayed by art." "If the florist," he says elsewhere, "enjoys the bloom of those resplendent gems, which, void of evident sensation and motion, yet stud the verdant fields, or decorate his gardens, and fill the air with fragrance, so much the higher should we prize those living tenants of the deep, which testify the action and volition diffused throughout their beautiful and luxuriant flourish."

When these Tubularia are kept for observation in vessels of sea-water, it generally happens, in a few days, that these beautiful heads drop off. It would be all over with man, 
even the wisest, were his head to drop off, unless we were to give credit to the legend of one of old, who, when decapitated, could run with his head under his arm. This marine knight of the oaten pipes can survive what would prove fatal to our doughtiest heroes. While the florid summit of the vacant stalk is fading, Sir J. G. Dalyell tells us that a kind of cicatrix closes the wound. But, on the lapse of a certain interval, it darkens again; an internal head is advancing, which, speedily ascending, bursts a transparent involucrum, and flourishes as a new head precisely from the same point its precursor had fallen, and of equally vivid hue. Singular to be told, the regenerative faculty is not exhausted here; for, after subsisting an indefinite time, this second head druops and dies, and is dissolved on its fall. Then it is replaced by a third, and the third by a successor." How often this may be repeated has not yet been ascertained.

The field botanist knows the pleasure arising from the power of association, leading him to remember that in some "lone glen of green breckan," or on some cliffy mountain-side, when, along with some dear friend, he first saw such a flower. I often remember that the first time I had the pleasure of seeing these living marine flowers was in 

$6 *$
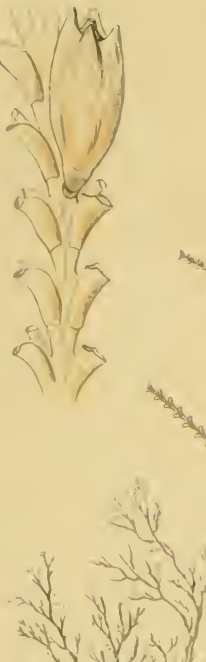

W

- $y+y$

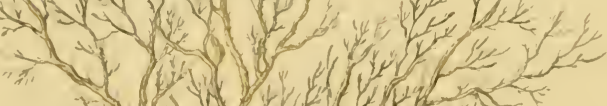

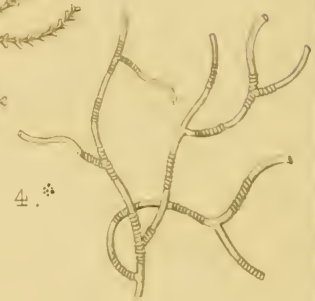

- N W

+ +1 V

a v N Y

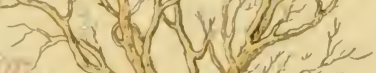

F.

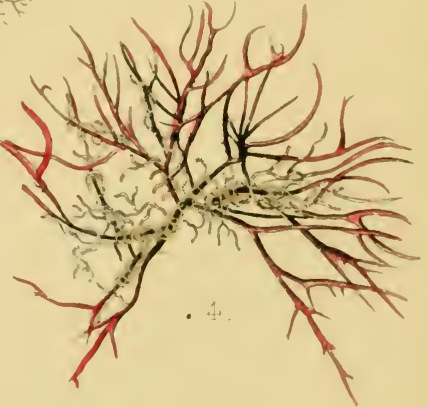


the romantic Kyles of Bute, aboard the yacht of Mr. Smith of Jordanhills, when dredging along with him and Professor Edward Forbes. A dozen precious years have passed since that delightful excursion.

2. Tubularia Dumortierii, Dr. Jolinston.

Hab. On the shell of the Lithodes maja, from Berwick Bay. "This is so like $T$. indivisa, that one might conjecture it was that species in miniature, but there can be no doubt of its distinctness." To be convinced of the truth of this, we have only to look at Dr. Johnston's fine figure of it, plate vii. 1, 2.

3. Tubularia larynx. (Plate II. fig. 4.)

Hab. Strangford Lough, W. Thompson; Belfast Lough, Mr. Paterson and Mr. Hyndman.

"This coralline is found in great plenty in the sea, near the opening of the Thames, adhering to other marine bodies, and often to the bottoms of ships. I have received it with the animals alive in sea-water, in which state it affords a most agreeable scene; the top of each tube bearing a bright crimson-coloured polype, equal in richness of colour to the Guernsey lily, all the animals displaying their claws or tentacula at the same time, with surprising agility."-Ellis.

It takes its specific name from the rings on parts of the 
tube, causing it to resemble the windpipe. "In the month of December," Sir J. G. Dalyell states, "a group was recorered from the sea, resembling a copious handfull of white, crisp, baked horse-hair, which rose two inches high, and occupied a vessel of four inches diameter. Closer inspection discovered this to be a vast congeries; - one of not fewer than 500 snowy tubes, crowned by scarlet animated blossoms of rarious hues. In the aggregate it may be compared to a beautiful tuft of pinks decorating a flowergarden." It is not often obtained in the west of Scotland. It seems more common in the north of Ireland. Mr. R. Paterson, of Belfast, says, "Having dredged a specimen, and having placed a detached tube of it in a jar of sea-water, this severed one, by its change of place, caught my eye. It was not merely that it was sinking in the jar, but that it was coiling itself up, uncoiling, stretching, twisting, knotting itself in a way that resembled the Gordius aquaticus;" thus showing that the stem is not only flexible, but, under certain circumstances, is truly and entircly under the control of the zoophyte.

4. Tubularia gracilis, J. B. Marvey.

Hab. In deep water, parasitical in tufts of Tulularia indivisa and Eudendrium rameum. 
I have a specimen of it from Lady Keith Murray, foun 1 by her near Stonehaven. This species is about three inches in height, the tubes slender, of a pale colour, and horny. "When the polypes are all displayed, they afford a very interesting spectacle, equalled by 110 other species I have seen; the crimson heads contrasting finely with their white polypidoms, especially when loaded with the reproductive bulbules, which pullulate from the inner side of the bases of the inferior tentacula." (Dr. Johnston.)-Mr. Harvey found his specimens at the steam-bridge on the river Dart, in clusters on the links of the chain, and also on the links over which the floating bridge at Devonport runs.

\section{Genus VII. CORYMORPHA, Sars.}

\section{Corymorpha nutans.}

Hab. Orkney, Forbes and Goodsir.

For the generic and specific characters we must refer to Dr. Johnston's work, pp. 54 and 55 , and to his characteristic figure, plate vii. fig. 4.

"We found the Corymorpha in ten-fathom water in the Bay of Stromness, Orkney. When placed in a vessel of sea-water, it preserited the appearance of a beautiful flower. 
Its head gracefully nodded (whence the appropriate specitic appellation, nutans, given to it by Sars), bending the upper part of its stem. It waved its long tentacula to and fro at pleasure, but seemed to have no power in contracting them. It could not by any means be regarded as an apathetic animal, and its beauty excited the admiration of all who saw it."-E. Forbes and J. Goodsir.

\section{Tribe 2. SERTULARINA. \\ FAMILy SERTULARIADA.}

Character. Polypidoms plant-like, horny, rooted, variously branched, tubular, filled with a semifluid organic pulp. Polypes contained within sessile cells, which are variously, but always determinately disposed along the sides of the main stalk or branehlets, and are never terminal; ova contained in horny deciduous vesicles scattered over the polypidom; embryos Planaria-like.

\section{Genus VIII. HALECIUM, Oken.}

Gen. Char. Polypidom rooted, plant-like: the stem composed of aggregated subparallel capillary tubes; the branches alternate, spreading bifariously; cells tubular, subsessile, jointed at the base, arising alternately from opposite sides, one under every joint of the branchlet: ovarian vesicles irregularly scattered. Polypes hydraform, scareely retractile within their cells. 



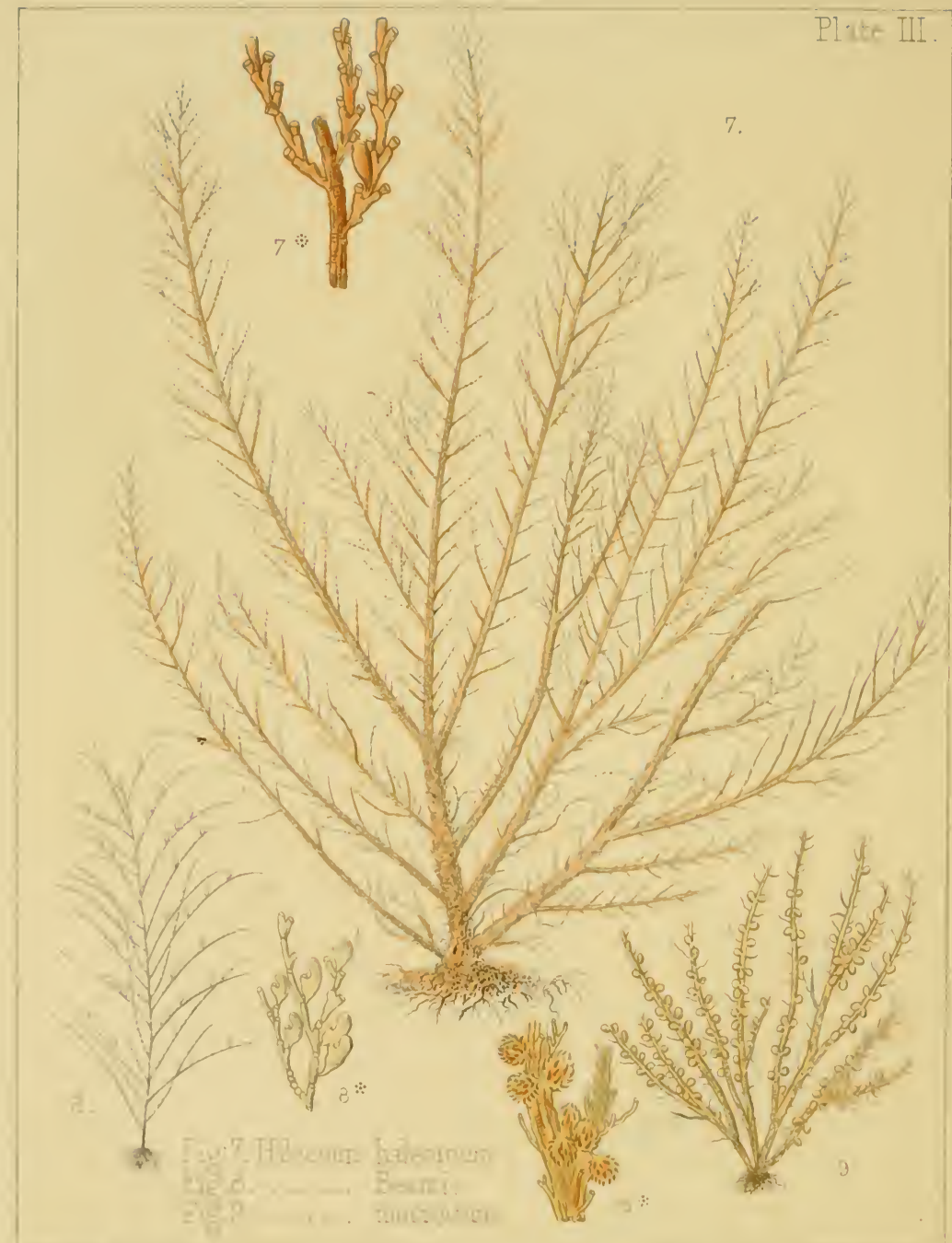


HALECIUM.

1. Halecium halecinum, James Newton. (PlateIII. fig. 7.)

Hab. On old shells and stones in deep water; generally common. Firth of Forth, D. L., jun.; Bootle Bay, Mr. 'Tudor.

Polypidom from four to ten inches high, attached to shells, etc., by numerous matted fibres; the stem and principal branches composite; "base of numerous tubes, which, by uniting, form those larger parallel tubes of which the stem consists; the smaller branches are simple, and diverge at a regular angle, each supporting a few alternate tubular cells, with one or two transverse wrinkles; vesicles on the sides of the branches, irregularly oval, with a tube on one side a little produced on the summit." (Dr. Fleming.)-As all the branches stand at an acute angle with the stem, this gives it an appearance which has procured for it the name of the Herring-bone Coralline. Though common on many shores, it is rather rare on the Ayrshire coast.

2. Halecium Beanit, William Bean. (Plate III. fig. 8.)

Hab. Near Scarborough, in deep water, rare, Mr. Bean; Belfast Bay, Mr. W. Thompson and Mr. Hyndman; Mr. IIassall, Dublin Bay; Professor Harvey, Dublin Bay. The first I saw of Scottish origin were sent to me by Lady Keith Murray, who found them at Stonehaven. I afterwards got 
it sent to me from the neighbourhood of Kirkcudbright, by Mr. E. B. Fleming; and soon after I dredged it in Arran, and found it also on our shore at Saltcoats. It is more slender and graceful than $H$. halecinum, and has little of the regular herring-bone appearance. The vesicles also are different in form, resembling the flower of a calceolaria, or rather a woollen slipper without any leather on the sole. When young, the colour of the polypidom is white; when old, it is brownish. The vesicles contain four embryos, which, when mature, make their escape through the orifice, and traverse the ressel in which they are kept, with their swelling head foremost. In this state they are called Planaria by Sir J. G. Dalyell. The vigour of their motion gradually relaxes till they become quite quiescent, and a stem rising from above indicates a nascent Halecium. Only six days is required to bring them to this degree of maturity, computing from the discharge of the planulæe from the vesicle.

The specific name given to it by Dr. Johnston is in honour of the indefatigable Mr. Bean, of Scarborough, by whom it was discovered. An excellent figure of it may be found in Dr. Johnston's admirable work, plate xi. 1, 2.

3. Halecium muricatum, David Slene. (PlateIII.fig.9.) 


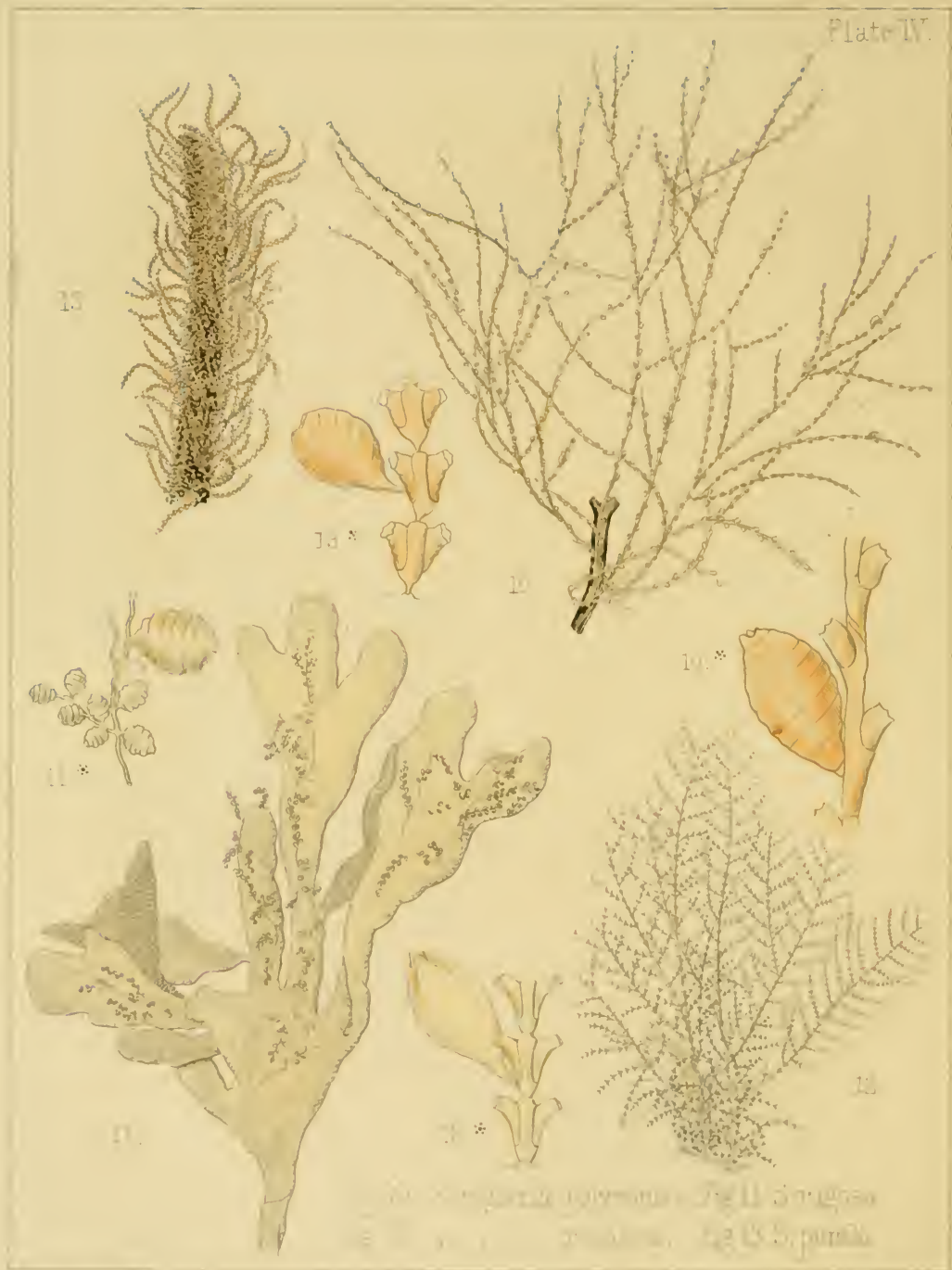


Hab. On old shells, from deep water. Aberdeen, Skene ; Angusshire,Don; Seaton, J.Hogg; Scarborough, Mr.Bean ; Dundee, W. Jackson, jun.; Firth of Forth, Dr. Jameson, Dr. Fleming; Dr. Coldstream; Cornwall, Mr. Couch; Giant's Causeway, Mr. Hassall; on oyster-shells from Lochryản, D. I.

Height two or three inches; stems erect, the stem and branches composed of closely agglutinated tubes; cells short and narrow; vesicles large, numerous, rough with spinous ridges. See the figure of it in Dr. Johnston's work, plate ix. fig. 3,4 .

\section{Genus IX. SERTULARIA, Linneus.}

Gen. Char. Polypidom growing in the shape of a plant, and fixed by its base, variously branched, the divisions or branches formed of a single tube denticulated or serrated with the cells, and jointed at regular intervals: cells alternate or paired, biserial, sessile, urceolate, short, with everted apertures: ovarian vesicles scattered. Polypes hydraform.-Dr. Johnston.

* Cells alternate, one to each internode.

1. Sertularia polyzorias, Great Tooth Coralline, James Newton. (Plate IV. fig. 10.) 
Hab. On shells, and roots of Fuci, and not unfrequently with us on the branches of Halidrys. It is common at Troon, and at other places on the Ayrshire coast. I have a specimen from Newfoundland.

It is loosely branched, cells smooth, not crowded, in some specimens a little wrinkled across. It is white, and two or three inches high.

There are two varieties, the one upright, and the other more branched and spreading.

"When this coralline was put into sea-water, I observed, through the microscope, a polype occupy the inside of the whole, and each denticle or cell filled with a part of it, ending in tufts of tentacula. A small picce of one of the little sprigs was put into a watch-glass of sea-water, and notwithstanding the separation of its body, in five minutes' time the claws or tentacula were moving about in search of prey." - Ellis.

2. Sertularia rugosa, Snail Trefoil Coralline, Ellis. (Plate IV. fig. 11.)

Hab. Parasitical on Flustra, sponges, and seaweeds at low-water mark; not uncommon. There is a variety which is erect, and another variety which creeps along the frond of Flustra foliacea. Seen by the naked cye, it has no beauty, 
seeming like a brown thread somehow attached, but when viewed with a lens it is a great curiosity, for it is crowded with coarsely wrinkled cells like little barrels. The vesicles are much the same, but larger, and have three teeth in the opening at the top of each.

** Cells in pairs, opposite, alternate.

3. Sertularia rosacea, Lily or Pomegranate Coralline, Ellis. (Plate IV. fig. 12.)

Hab. On shells from deep water, and also on Laminarice, but much more frequently on Plumularia falcata, Sertularia argentea, and $S$. cupressina, and on these it is much more delicate and graceful than on seaweeds.

It is from one to two inches in height, very slender and delicate, of a pale horn-colour, pellucid ; cells opposite, tubulous, the upper half free and divergent. Ellis saw the animals alive both in the cells and in the vesicles, those in the vesicles being considerably larger.

4. Sertularia pumila, Sea-oak Coralline, S. Doody. (Plate IV. fig. 13.)

Hab. Near low-water mark; very common on Fucus norlosus and Fucus serratus. The branches rise from a tubular thread that creeps along the surface of the Fuci, and they often rise in such numbers as to cover the alga. In general 
they are less than an inch in height, but at Leith we got them nearly two inches, completely covering the frond of the $F$. serratus. 'The colour is horny; the cells are opposite; the vesicles scattered and ovate. This species is very phosphorescent when the seaweed to which it adheres is suddenly shaken in the dark.

5. Sertularia Evansit, Mr. John Evans.

Hab. Yarmouth, where it was found by Mr. Evans, in honour of whom it was named by Ellis, to whom it was sent in 1767. It does not seem to be much known.

6. Sertularia nigra, Pallas.

Hab. Found at the Lizard, Cornwall, Pallas; in several places in Cornwall by R. Q. Couch; Deronshire, Mrs. Griffiths.

Robust and erect, from three to seven or eight inches ligh, of a blackish-brown colour when dead, at times tinted with red. "But to see it in all its beauty," says Mr. Couch, " it must be examined in a living state, and soon after it is taken from the sea, when, instead of being black, it will be found of a beautiful and delicate pink, and in some instances of a deep arterial blood-colour. It is the stoutest and most rigid of all our native Sertularia, but there are several others which exceed it in beauty and delicacy." 
See Dr. Johnston's figure of Sertularia nigra, plate xii. fig. 1, 2 .

7. Sertularia pinnata, Pallas.

Hab. At the Lizard, Cornwall, Pallas; Devonshire, Mrs. Griffiths. I have it from Mr. Bean, Scarborough.

Mrs. Griffiths mentions respecting this rare zoophyte that when fresh it is entirely of a deep blood-red colour, and when dried, brown. Pallas remarks that there is the closest resemblance betwixt it and S. nigra; and Dr. Johnston states that the real difference between them lies in the position of the cells and in the form of the vesicles. The cells arise, not from the sides exactly, but rather on the edge of the pinnules; the vesicles are comparatively small, obconical, with a series of tubercles or segments above, while the centre projects in the shape of a cone or nipple. See Dr. Johıston's figure, plate xii. fig. 3, 4.

8. Sertularita fusca, Robert Brown.

Ulab. Coast of Aberdeenshire, R. Brown; coast of Northumberland, Mr. Embleton; Scarborough, Mr. Bean ; Whitburn, county of Durham, Miss Dale; Stonehaven, Lady Keith Murray.

It is about three inches high, rigid, pinnate, dusky, blackish-brown, varnished. The cells are arranged in a 
cross row along each margin, and have a quadrifarious appearance. The cells are small; the vesicles pretty large, unilateral, pear-shaped, and smooth. I am indebted to Lady Keith Murray for a good specimen of this rare species, found at Stonehaven on the fishermen's nets.

9. Sertularia pinaster, $W$. Thompson.

Hab. Mr. W. Thompson, of Belfast, states respecting this rare species, that it was dredged by Mr. Hyndman in Belfast Bay, and also off Sana in the western coast of Scotland. A single specimen also was dredged by Captain Beechey, R.N., off the Mull of Galloway. It bears a resemblance in form to S. rosacea, as may be seen by looking at Dr. Johnston's figure 12 , page 72 . The difference lies in the ovarian vesicles.

10. Sertularia Margarita, $R$. A. Tudor.

Hab. Mouth of the Mersey, Mr. Tudor; off Howth, and near the Giant's Causcway, Mr. Hassall ; Dublin Bay, Professor Harvey; Devonshire, Mrs. Griffiths; Arran, D. L.

This bears a considerable resemblance to $S$. pinaster in the shape of the cells, but it differs from it in the shape and in the larger size of the vesicles, which are rounded at the top and arranged in two circles. See Dr. Johnston's Zoophytes, fig. 13, p. 73. 
Mr. Tudor, of Bootle, had found this, and it had been sent to Dr. Johnston by his friend Mr. Rylands, named S. Tudori, but as it wanted vesicles Dr. Johnston delayed publishing a description of it, in the hope that a specimen with vesicles might be found by Mr. Tudor. In the meantime it was found with vesicles by Mr. Hassall, who assigned to it the christian name of a lady distinguished for an ardent love of the works of nature, and also as a zealous collector in various branches of natural history.

11. Sertularia fallax, Dr. Fleming.

Hab. On oyster-beds, common, Dr. Fleming; Frith of Forth, plentifully, Dr. Coldstream; near Dunstanborough, Mr. Embleton; Whitburn, Miss Dale; Scarborough, Mr. Bean; Aberdeen, Mr. J. Macgillivray; Stonehaven, Lady Keith Murray.

Attached by tubular fibres; from two to four inches in height, branches alternate; rachis of a dusky horn-colour; cells tubular; ovarian vesicles pear-shaped, with four convergent segments at the top. I have not met with this on the Ayrshire coast, so that the only specimen $\Gamma$ have of it is from Lady Keith Murray, found by her at Stonehaven.

12. Sertularia tamarisca, Sea Tamarisk, Ellis. (Plate II. fig. 6.) 
Hab. Entrance to Dublin Harbour, Ellis; Belfast Lough, Templeton; Ballycastle, Dr. J. L. Drummond; Howth, Mr. R. Ball; Portmarnock, Mr. W. Thompson; near Aberdeen, Dr. Skene; Frith of Forth, Dr. Coldstream; Scarborough very rare, Mr. Bean; Bootle, Mr. 'Tudor; Cornwall, Mr. Couch; Devon and Norfolk, very rare indeed, Mr. C. W. Peach.

"Its ramifications are irregular, but chiefly alternate; its texture is of a thin, transparent, horny nature ; the denticles or cells are large, cylindrical, open and opposite, and each pair scems fixed in the top of the next pair below it. The vesicles appear to be shaped like a heart, with a short tube at the top, not unlike the aorta, cut off." (Ellis.) It bears some resemblance to $S$. rosacea, but it is of a much more robust habit. I have not observed it on the Ayrshire coast, but I have fine specimens of it from my liberal friend Mr. Tudor, and also from D. L., junior, got in the Frith of Forth.

13. Sertularia abietina, Sea-fir Coralline. (Plate V. fig. 14.)

Hab. On shells and stones in deep water, common. It is not common, however, on the coast of Ayrshire. We have occasionally picked up a specimen, having, however, a 


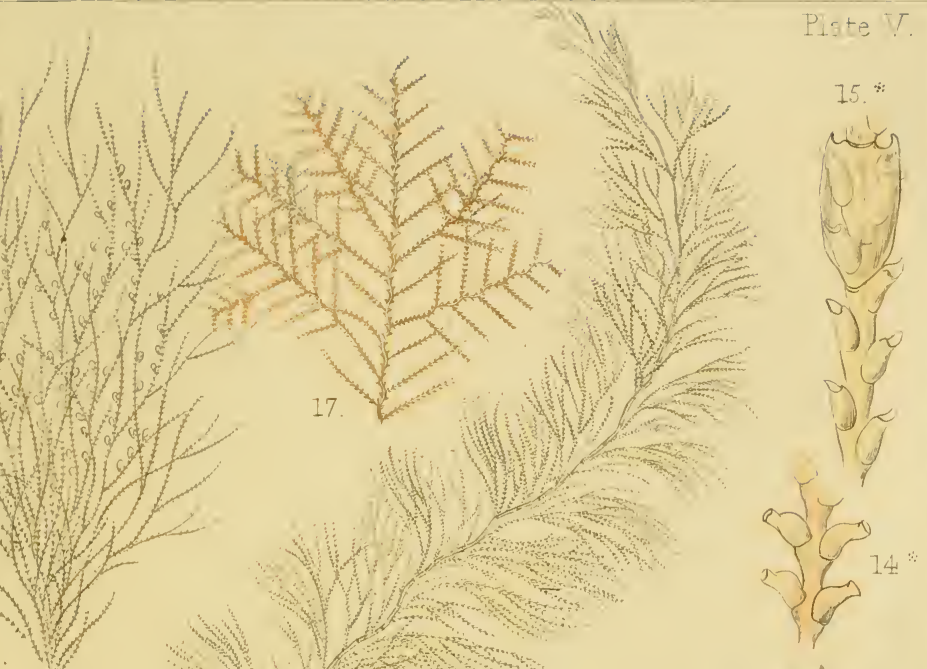

Wyy WWIY ${ }_{17 .}$ WW (W)

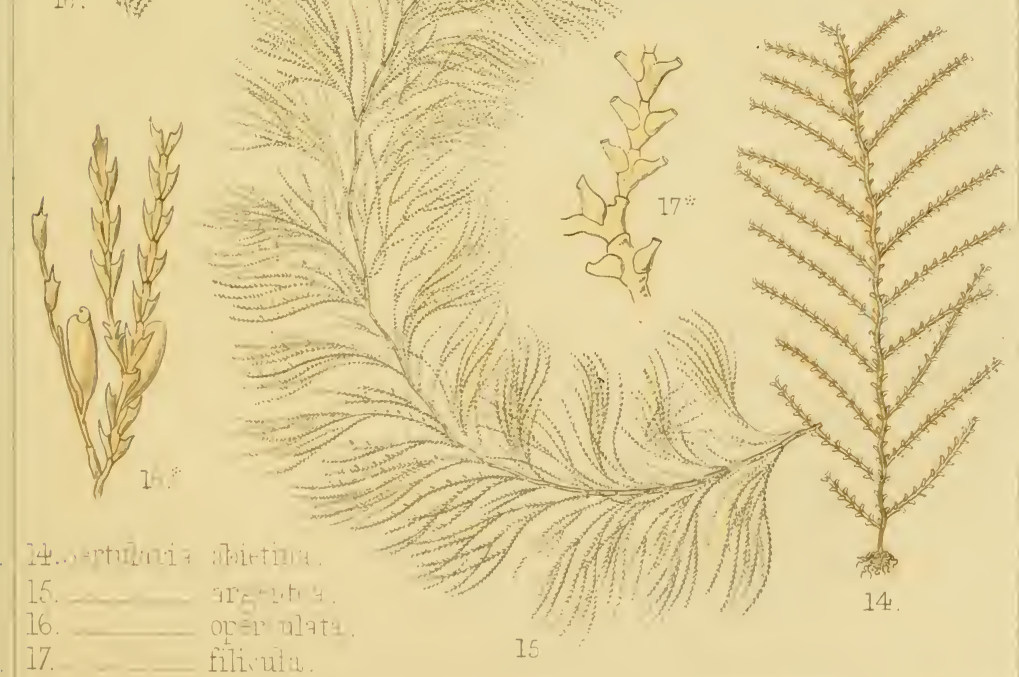


bleached appearance, as if drifted for a considerable time. We have dredged it in Lamlash Bay, but the specimens, though evidently in their native locality, were not good.

"Height nearly a foot; stem arising from wrinkled tubes, which adhere to stones or shells; the cells are usually opposite, sometimes alternate, and the stems seldom exhibit any joints; vesicles egg-shaped, with a narrow base and a contracted subtubular summit." (Dr. Fleming.) Though generally white, or of a pale yellow colour, specimens of a reddish hue are occasionally found. Those I got in Arran, and in the Frith of Forth, where they are abundant, were very much dotted with Spirorbis.

Sir J. G. Dalyell has recorded many interesting observations made by him on this zoophyte, kept alive in jars of sea-water. "It is obvious," he says, "that two differently formed vesicles are horne by the S. abietina, a fact also incident to a few other Sertularice."

He gives a description and figure of what he calls Sertularia abietinula, diminutive sea-fir. It bears a considerable resemblance to $S$. abietina, but he has been unable to identify the two. It is generally from one to two or perlaps three inches high. He has never observed it except on old shells. 
14. Sertularia filicula, Fern Coralline, Hudson. (Plate V. fig. 17.)

Hab. On seaweeds, especially on the entangled roots of Laminaria digitata; Mr. W. Thompson states that it seems to be partial to bivalve shells on the coast of Ireland, and it is also found on Flustre. It is rare in the west of Scotland, and is seldom found except at the roots of L. digitata. It is not common anywhere, though it is widely distributed.

"Height about an inch; branches alternate; cells wide at the base, contracted towards the orifice, which is slightly tubular, with a wrinkle or depression, forming a shoulder on the upper side; vesicles ovate with a narrow base, and a contracted subtubular orifice." (Dr. Fleming.) "It sometimes rises to the height of four inches; the stem has a zigzag appearance; the cells are shaped like a Florence flask. The vesicles are represented by Ellis as pear-shaped, but they are very seldom seen. The singularity of its waved stem, with its erect, single, axillary cell at the insertion of the branches, together with the single pair of cells on each part of the stem that form the angles, make it a very distinct species from any of this genus." (Ellis.)

Though it bears some resemblance to a young specimen of $S$. abietina, it may be easily distinguished, as Ellis has 
said, by the zigzag stem, the single upright cell in the angle betwixt the stem and the branch, and by there being only two cells, one on each side on that part of the stem which intervenes betwixt every two branches.

15. Sertularia operculata, Ser-hair Coralline. (Plate V. fig. 16.)

Hab. On seaweeds, especially on the stem of Laminaria digitata. Common on all parts of the coast. And yet, common as it is, I had been several years minister of an Ayrshire parish with five miles of sea-coast, from Saltcoats to Irvine, before I ever saw either this or any other zoophyte; or more properly speaking, before I observed one of them, or gave that degree of attention which is necessary to discern their beauty. When S. operculata was shown me by a naturalist whom I met on the shore, I was so much struck with its elegant structure, that I thought it must be some foreign production, and could scarcely believe that so great a curiosity could be found on our own shores. Ashamed of having so long had eyes and no eyes, I began to make a better use of them; and having detected some other zoophytes of equal beauty, I sent them to my kind and excellent friend Dr. Fleming, who gave me their names and encouraged me to prosecute my marine researches. "It consists," as Ellis 
states, "of long trailing branches, with very sharp teeth, placed in pairs exactly opposite; each pair seems to be jointed into the next. The slender branches grow in tufts like bunches of hair. On the Ayrshire coast I have never observed it on anything but Laminaria digitata, and seldom more than three inches in height, but English specimens are often six, and Irish specimens sometimes even twelve inches in height. 'After a storm, clumps, as large as a child's fist, are washed ashore.' (Couch.) The vesicles are irregularly scattered on the branches, large, smooth, egg-shaped, and often with a rounded operculum at the top." "It was from the great resemblance," says Dr. Johnston, "of these vesicular ovaries to the capsules of mosses, that the early botanists drew an additional argument in behalf of the regetability of the corallines themselves; and a Darwinian might be, perhaps, forgiven, were he even now to feign how the Nereids stole them from the mossy habitats of Flora's winter and vernal shows, to deck and gem the arbuscular garnitures of their coral caves."

"Nymphs! you adorn, in glossy volutes roll'd, The gaudy couch with azure, green, and gold.

*

You chase the warrior shark and cumbrons whale,

And guard the mermaid in her briny vale: 
Feed the live petals of her insect flowers, Her shell-wrack gardens and her sea-fan bowers;

With ores and gems adorn her coral cell, And drop a pearl in every gaping shell."-Botanic Garden.

Mr. W. Thompson states, "I have collected a few examples of a black, as well as many of a red colour."

16. Sertularia argentea, Squirrel's Tail Coralline. (Plate V. fig. 15.)

Hab. In deep water. On oysters, and other bivalve shells. In brackish water, in shallow pools, and on the floodgates of a dam in Belfast, Mr. W. Thompson.

This beautiful feathered coralline is found in great abundance, Ellis states, in the island of Sheppey, eastward of Sheerness, growing on the rock oysters. "It generally grows erect," he adds, "with thick tufts of alternately denticulated ramifications placed in a spiral or screw-like order round the stem from top to bottom." The whole coralline assumes somewhat of the shape of a squirrel's tail, whence the common English name. It is an exceedingly elegant polypidom, rising sometimes to nearly a yard in height, and, from being quite flexible, waving in the sea as the somewhat similarly-shaped Swedish junipers wave in the breeze. When it gets old, the under part of the stem becomes quite 
bare of branches. It is very beautiful in its young state, when it is only two or three inches in height. It is then found in clusters of twenty or thirty close together; but when there are only three or so in the cluster, it is peculiarly handsome, resembling a silvery Prince of Wales's feather. I had the pleasure of finding it in this juvenile state several times betwixt Leith and Portobello. I have had many fine specimens of it found in the Mersey by Mr. Tudor, and many also found by Miss M'Leish and the Misses Steel, in the Dee, Cheshire. As it is rarely found on the Ayrshire coast, I was happy to get a good supply from Miss Griffiths and Miss Cutler when I had the great pleasure of visiting them in April, 1851 ; and, being greedy of such beauties, I added to my stores, when about the same time I enjoyed the happiness of an excursion with Mrs. and Misses Gulson to the Warren, opposite to Exmouth. The Warren is, with the exception of Guernsey and Jersey, the only habitat in Britain for the beautiful little crocus-like plant Trichonema columna, and a gladder note of exultation was raised by us all on its being discovered by Miss Gulson, because there were fears that it liad been eradicated, as several botanists had been searching for it in vain.

17. Sertularia cupressiva, Sea Cypress, Ellis. 
Hab. Cornwall, Mr. Couch; Scarborough, Mr. Bean; Frith of Forth, Jameson; Cork Bay, J. V. Thompson; Magilligan Strand, Templeton; Dublin Bay, Hassall; rare in Cornwall, plentiful in Devon and Norfolk, C. W. Peach; Mersey, Mr. Tudor; Dublin Bay, Dr. Scouler.

This is a stouter polypidom than the preceding, though it does not rise to so great a height; the branches, however, are larger and more fan-shaped, bending gracefully as if laden with a rich cup of vesicles, arranged in close order on the upper side of the branches. The vesicles are oval, and smooth.

This, though exceedingly beautiful also, is rather coarser and less elegant in appearance than the preceding, unless the specimen be more than usually fine.

It still remains undetermined whether they be really two distinct species. Ellis thought them distinct species; Mr. Hassall points out what he thinks sure marks of distinction. J. V. Thompson and Mr. Bean consider them distinct. Pallas, and Linnæus after him, regard them as one species. Sir J. G. Dalyell, Dr. Fleming, and Dr. Johnston seem to have doubts as to their being different species, and we are disposed, along with Mr. W. Thompson, to think that they run into each other. 
"I cannot perceive any permanent character by which $S$. cupressina can at all times be distinguished from $S$. $a r^{*}$. gentea, although typical specimens of each form bearing these names appear considerably different from each other. Both are found around the Irish coast, and together with many other zoophytes constituted the most beautiful collection of these objects I ever beheld, when gracefully depending from, and interlacing, the spacious trawl-nets of the Howth fishermen, as they were hung up to dry on the decks of the fishing-smacks. Of the numerous species then obtained, $S$. argentea and $S$. cupressina were the most attractive, from their graceful form and magnitude, some examples attaining to nearly two feet in height." ( $W$. Thompson.)

When Sir J. G. Dalyell mentions one which was twentyseven inches in height, he speaks of it as the largest of our Scottish zoophytes. This held true at the time he wrote, but since that time a specimen of Pavonia quadrangulata has been dredged near Oban no less than four feet in length.

\section{Genus VII. THUIARIA, Fleming.}

Gen. Char. Polypidom plant-like, rooted by a tubular fibre, erect, dichotomously branched or pinnated: the cells sessile, 


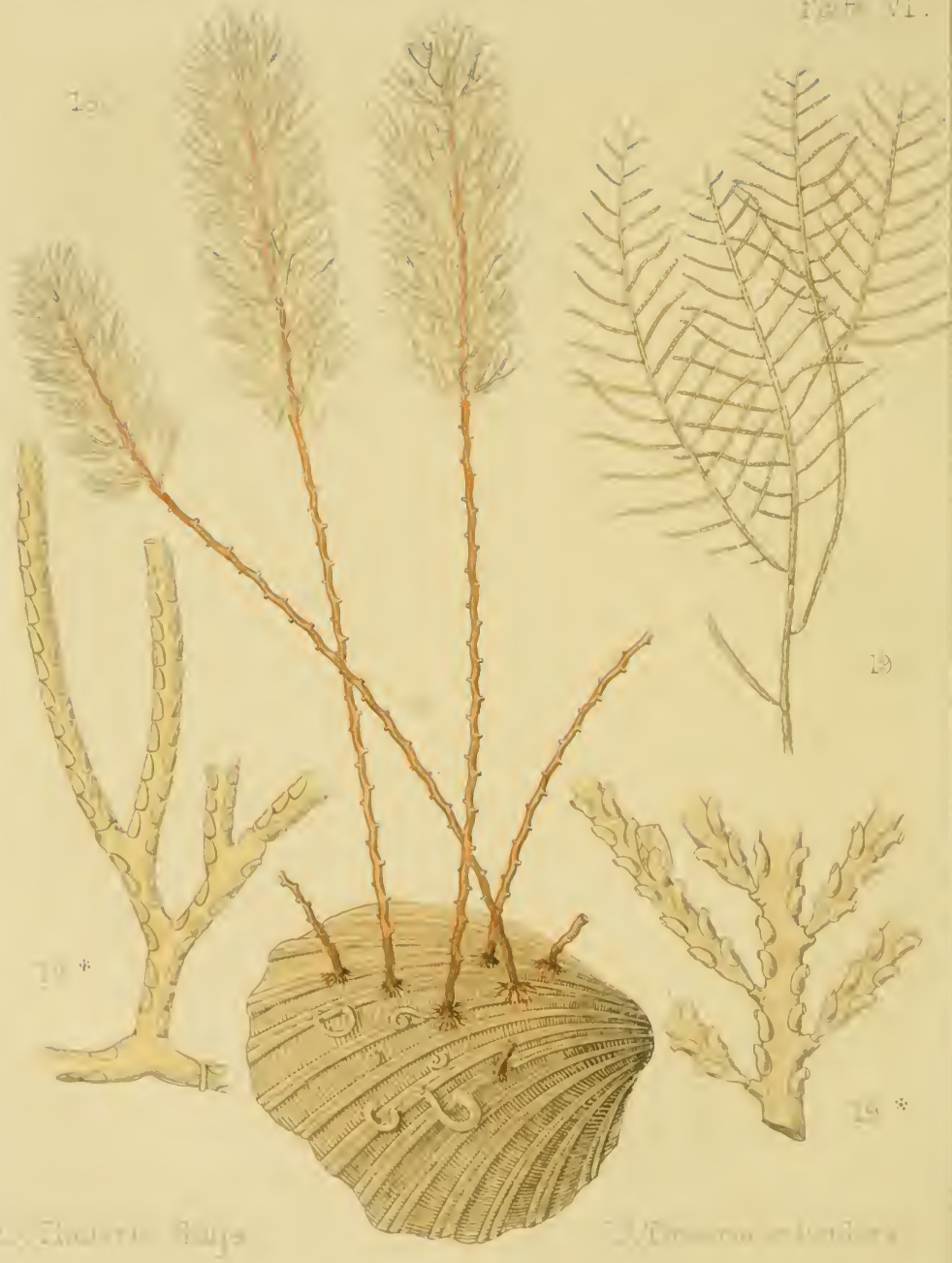


biserial, adnate to the rachis or " imbedded in the substance of the stem and branches:" vesicles scattered. Polypes hydraform.- Joliniston.

1. Thuiaria thuia, Bottle-brush Coralline, Sir R. Sibbald. (Plate VI. fig. 18.)

Hab. On shells from deep water; Scarborough, Ellis; coast of Durham, J. Hogg; North Durham and Berwickshire, Dr. Johnston; coast of Cornwall, rare, Mr. Couch; Leith, Jameson; Stonehaven; north of Ireland, Mr. W. Thompson. The name from the Greek word for a cedar.

This is a very remarkable coralline, and it cannot, in its mature state, be mistaken for anything else. It is from eight to twelve inches in height. The stem is erect, horny, and a little zigzag. The alternate branches below fall off, and leave the stem naked with only a tuft of branches towards the top, giving it much the appearance of a bottlebrush. Cells close-pressed to the stem. Vesicles pearshaped, on the upper side of the branches. Young specimens are simply pinnate, without any tuft at top.

2. Thuiaria articulata, Sea Spleenwort, or Polypody, Ellis. (Plate VI. fig. 19.)

Hab. On shells and stones in deep water, Dublin Bay, Ellis; Donaghadee, Mr. W. Thompson; Isle of Man, Pro- 
fessor E. Forbes; Sana Island, off Kintyre, Mr. Hyndman ; Liverpool, Mr. H. Johnson; Whiteburn, Miss Dale; Scarborough, Mr. Bean; Bootle Bay, Mr. Tudor; Cornwall; Devon; Norfolk, Mr. Peach.

This zoophyte is generally three or four inches high, though Mr. Hyndman has dredged it on our west of Scotland coast six, and in one instance, ten-and-a-half inches in height. It is a remarkably handsome zoophyte, of a palish horn-colour, clean and clear; the pinnx, which are subalternate, branching out like polypody, whence its English name. The cells are in rows on each side of the pinne. The vesicles are generally on the upper side of the pinne, though occasionally on the under. I have some finely branched specimens of it from Mr. Tudor at Bootle.

\section{Genus VIII. ANTENNULARIA, Lobster's Horn}

\section{Coralline, Lamarck.}

Gen. Char. Polypidom plant-like, horny, simple or branched irregularly, the shoots fistular-jointed, clothed with hairlike verticillate branchlets; cells small, sessile, campanulate, unilateral; vesicles seattered, unilateral. Name from the feeler of an inseet. Polypes hydraform.-Johnston. 


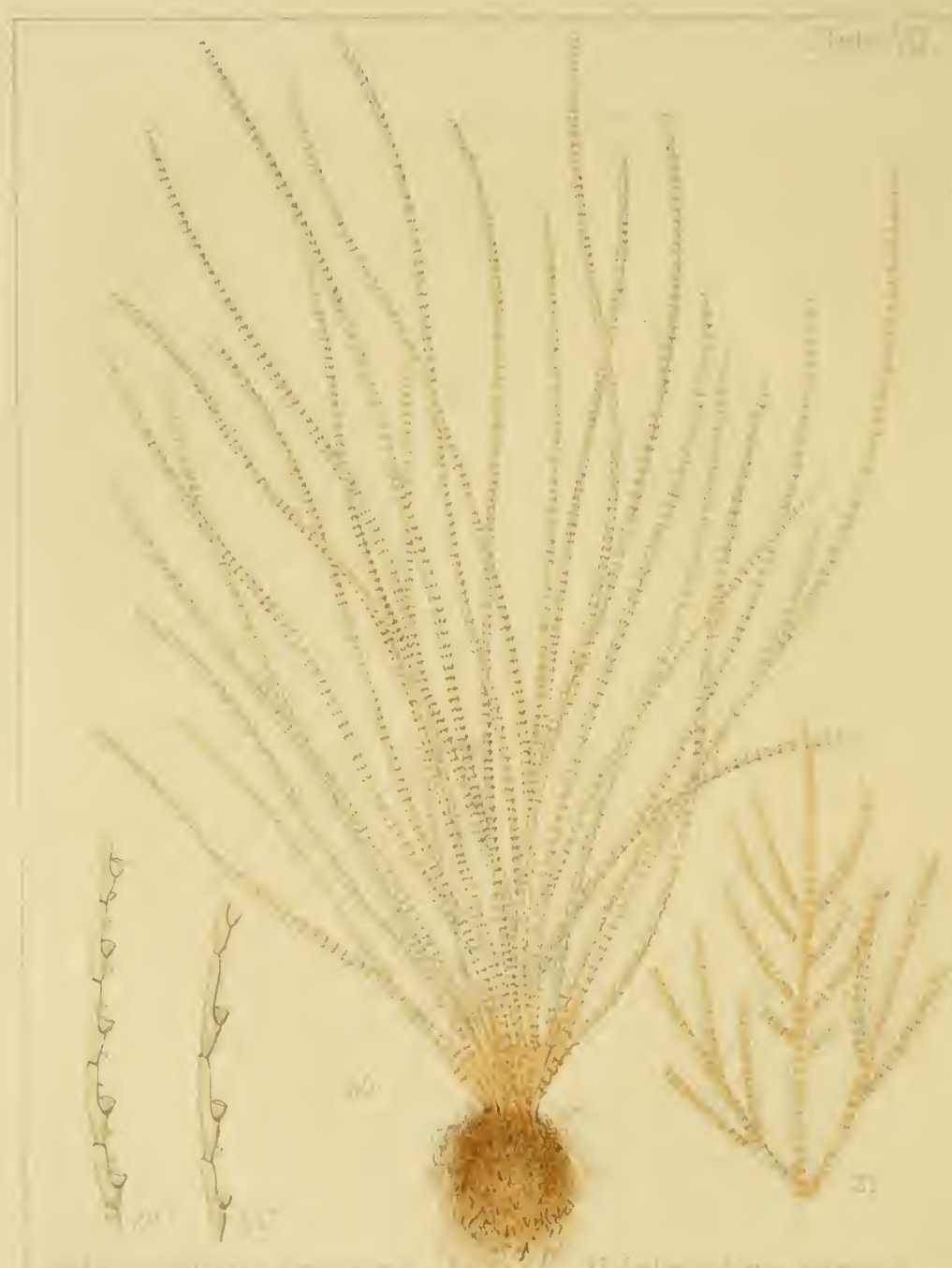


1. Antennularia antennina, Mrs. Ward. (Plate VII. fig. 20.)

Hab. Grows in clusters in the sand or on stones lying in the sand, rooted together by numerous fibres matted with a mixture of broken shells and sand. Pretty generally distributed. We have not found it on the Ayrshire coast, if it is distinct from the succeeding. It has, however, been got by the Reverend Mr. Urquhart at Portpatrick, and we have remarkably fine specimens from Dr. Beverley Morris, from the coast of Yorkshire; from Dr. Scouler from Dublin Bay; and from Major Martin, from Lough Swilly. These last were very handsome, but the stems smaller and more compact than usual, and the branchlets shorter.

The height is often upwards of a foot. It is jointed from root to tip like a lobster's horn, or like the vertebræ of fishes. "Each articulation is surrounded by short capillary branches, which, when magnified, have the appearance of sickles, and bend in towards the main stem. Along the inside of these are placed minute sockets, which support small open denticles (cells) of a cup-shape, which are of so tender a nature that they are scarcely visible but in recent specimens. Between the minute hair-like branches we have observed on some specimens small egg-shaped vesicles fixed 
on footstalks, with their openings or moutlis on the side of the top of each, looking towards the middle stem." (Ellis.) We lave fine specimens with vesicles from Dr. Scouler, Dublin.

1)r. Johnston says, "This very fine zoophyte is agreeably associated in my mind with recollections of my friend Charles William Peach." Though we have not room for the interesting narrative which Dr. Johnston subjoins, we may give a sentence from Mr. Peach's statement. "From being all my life confined inland and not having seen the sea, I was much struck with all connected with it; and I well remember how delighted I was with a most splendid specimen of Antennularia antennina which was placed upon the chimneypiece of the little parlour of the inn I stopped at when I joined my station. It excited a curiosity which was not satisfied until I found out what it was, and I believe I may date my progress from that time."

2. Antennularia ramosa, D. Dare. (Plate VII. fig. 21.)

Hab. On old shells and stones from deep water. Ray mentions it as collected by Dare, a London apothecary, " in littore Dulrensi," Dover. Cumbraes, Major Martin; Lamlash Bay, D. L. 
It is very much disputed whether this is distinct from A. antennina, or only a variety of it. Ellis, Pallas, Fleming, Couch, and Johnston hold that it is but a variety; while Ray, Lamarck and Lamouroux, Hassall and Macgillivray, and Mrs. Griffiths, "an authority," as Dr. Johnston says, "always quoted with fond respect," all agree in thinking them distinct species. To the latter I would add my humble opinion. Major Martin and I have dredged many fine specimens of $A$. ramosa, all springing from a single stem of two or three inches, and then dividing into several branches, and all being shaggy with long branchlets; and we never have got one specimen of the typical sea-beard clustered from the base, and not dividing into branches. Dr. Johnston remarks, "Mr. Hassall was the first to say, on apparently better grounds, that these varieties might be really species. He tells us that ' $A$. ramosa arises by a single trunk, which subsequently divides and subdivides into numerous branches; the branches are long, and the cells are not separated from each other by one or more small cup-like processes, as are those of $A$. antennina.' The value of these characters has been confirmed by Mr. J. Macgillivray;" and Dr. Johnston adds, that the absence of these cells, together with the peculiar hatit, seem to justify 
Mr. Hassall in considering his A. ramosa as a good species; though there is another (slightly) branched state of $A$. antennina, unquestionably a mere variation, being provided with the tubular cells above alluded to.

\section{Genus VIII. PLUMULARIA, Lamarck.}

Gen. Char. Polypidom plant-like, rooted, simple or branched, the shoots and offsets plumous: cells small, scssile, unilateral, usually seated in the axillæ of a horny spine; vesicles scattered, unilateral. Polypes hydraform.-Dr. Jolnnston.

\section{* Stem a single tube.}

1. Plumularia falcata, Sickle Coralline, Merrit. (Plate VIII. fig. 22.)

Hab. On shells and rocks near low-water mark, and in deep water.

"This elegant feathered coralline adheres to rocks and shells by little wrinkled tubes, and rises from them into erect stems, which are surrounded from bottom to top with pinnated branches; the smaller divisions of these have rows of little denticles or teeth or cells on the side, and bend inwards, as they become dry, in the form of a sickle." 


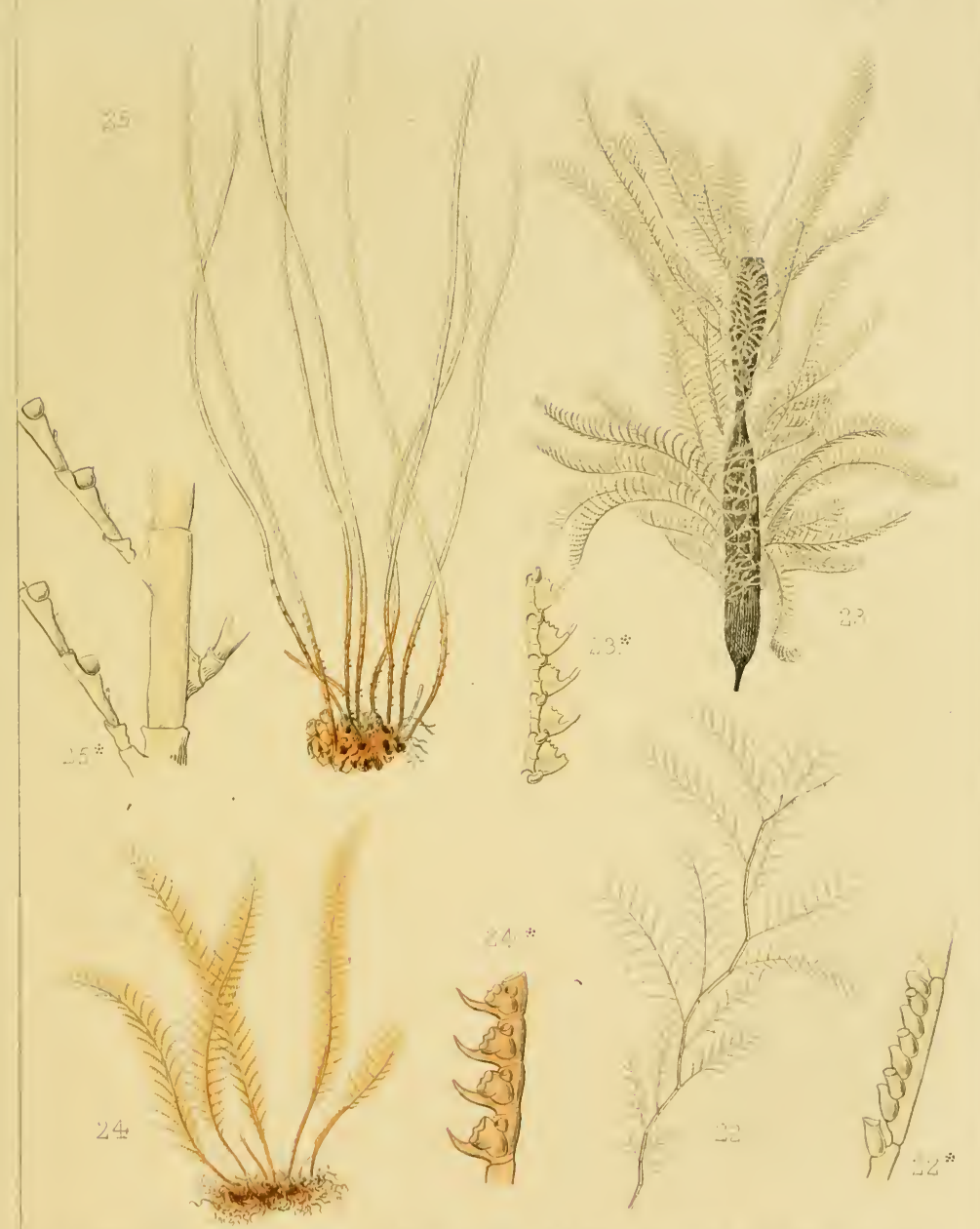


$+$ 
(Ellis.) It is sometimes a foot in height. The largest I have were got by Major Martin in Lough Swilly. Some years ago I gathered great abundance on the shore betwixt Leith and Portobello, with vesicles which Dr. Johnston speaks of as rather rare. In May, 1851, I had the pleasure of gathering, at Exmouth, in company with Mrs. Gulson, specimens in fine fructification, and of receiving about the same time, from Mrs. Griffiths and Miss Cutler, other specimens loaded with vesicles. Sir J. G. Dalyell states that the specimens are either yellow or white, but that on the same specimen there is not a mixture, for all are yellow or all are white. He has observed that both, when mature, sent forth planulæ, little living creatures; but we have not space for his observations; and, for the same reason, we must refer to Dr. Jolnnston's excellent work, page 91, for very interesting and instructive observations by Professor Grant.

2. Plumularia cristata, Podded Coralline, Ellis. (Plate VIII. fig. 23.)

Hab. On Fuci, especially Halidrys siliquosa. "Sometimes on mussels and other shells." Mrs. Griffiths, Miss Cutler, Mrs. Alexander, Devonshire; around the coast of Ireland, Mr. W. Thompson; coast of Ayrshire, D. L. ; Dublin 
Bay, Dr. Scouler; Mr. Tudor, Bootle; Prof. E. Forbes, Isle of Man.

The little radical tubes of this coralline are often found entwined around the stem and branches of Halidrys. "From these arise little branches like feathers; each smaller division of a branch is curved, when dried, like a sickle, and the denticles (cells), which are fixed in a row on the inside, are shaped, when magnified, like the flowers of the lily of the valley." (Ellis.) The vesicles are large and very curious, resembling a swollen pod, with several cristated ribs girding it. When recent, Dr. Coldstream states "that they are translucent, and that six or seven dark oval masses may be seen within each, which seem to be ova." This coralline is a great favourite of mine, and it is often found after a storm on the Ayrshire coast, and always on Halidrys siliquosa. When in the water, or fresh from the deep, it is remarkably beautiful; every branch is like a handsome little feather, generally of a rich cream-colour, occasionally finely tinted with red. Mr. Lister remarks, " Many specimens all united by a common fibre, and all the offshoots of one common parent, are often located on one seaweed, the site then of a population which nor London nor Pekin can rival. It is such calculations-always un- 
derrated - that illustrate the 'magnalities of Nature,' and take us by surprise, leaving us in wonderment at what may be the great object of this her exuberant production of these 'insect multitudes peopling every wave.'"

3. Plumularia pennatula, Feather Coralline, G. Montagu. (Plate VIII. fig. 24.)

Hab. Coast of Devonshire, Montagu; on Pinna ingens, Cornwall, rare, Couch; from a crab, and from Laminaria digitata, Mr. Peach. "Specimens of this rare and beautiful species profusely invest about six inches of the stem of $L$. digitata, obtained in a fresh state by Miss M. Ball at Youghall," W. Thompson; Roundstone, Galway, M‘Calla.

A person has only to look at the figure in the plate to see that "this coralline is as remarkable for the elegance of its form as its likeness to the feather of a pen." Height from three to six inches. I have never seen but one specimen of it, and for that I am indebted to the kindness of Mr. W. Thompson, who received it from Miss Ball.

4. Plumularia pinnata, Branched Sea Bristles. (Plate VIII. fig. 25.)

Hab. On shells, stones, and other corallines; deep water. The finest specimens of this handsome coralline I have ever seen were dredged in Lamlash Bay, attached to Pecten. 
opercularis. They were fully four inches in height. Dr. Johnston says, "it is very delicate, of a white or rarely horn-colour" (with us always white), "simple, plumous, and pretty." The cells are transparent; the vesicles, in the West, are often produced in great abundance, and the aperture, after the expulsion of the ova, is cut into a circle of spinous teeth, or, as Ellis expresses it, "the tops of the ovaries are divided like a coronet."

When the dredge had brought up some fine specimen of more than four inches in height, as the boatmen expressed surprise that we should care for what was, in its collapsed state, as worthless-looking as a wetted feather, I told them to hand me some water in a vessel which was in the boat, and plunging the Pecten with several fine specimens on it into the water, I told them to look at it now. Every specimen being now spread out in its native beauty, they were filled with astonishment, saying they did not think that there had been anything so bonny in the whole bay*. Meet-

* "These beautiful algre were not the only parasites on the scallop-shells. There was somcthing more conspicuous, as it was about four inches iu length, but ccrtainly it did not seem more attractive: it was like a drookit white feather. But place it again in the water, and what does it become? It has recovered from its state of collapse, and though still like a feather, it is one of great beauty and elegance;-it is a zoophyte, Plumularia pinnatu. You 
ing the wife of one of the Arran boatmen, in a succeeding season, I asked her if her husband had been getting many clams (i.e., Pectens) lately; she said, "Ah no, he has been getting hardly onything ava' (at all). Some vile ne'erdo-weels set their lines on the Sabbath day, and fish and clams ha' a' left the island;-and nae wonder." "Nae wonder," responded I, "nae wonder." "We have had very boisterous weather this spring, Janet, are you not frightened when Donald is out fishing, when the weather is so stormy?" "Na, na; its stormy aneugh whiles, but Donald's no the gear that trails*. He aye fins the road hame." "But was

would not think that that beautiful white feather had life;-but you see only the habitations. The alarmed inhabitants have fled into their houses. But place the polypidom, as it is called, in a tumbler of sea-water, and when the alarm is over, the inhabitants will again appear. The polypes are hydraform, and spread forth many teutacula in search of food, which they greedily grasp. The feather is formed of calcareous matter mixed with gelatine to give it flexibility, so that it may the better stand the buffeting of the waves. Observe the stem or quill of the feather, and you will see that it is full of red matter. That is the medullary pulp. Every plumule of the feather is a street. Even with the naked eye you may observe on each plumule about a dozen notches. Eaeh of these is the house or cell of a polype; so that in a good specimen we see a kind of marine village, which, under the teaching of God, has been beautifully constructed by the thousand inhabitants it contains." - Extract from 'Excursions to the Island of Arran,' by D. L.

* Goes amissing. 
not he very unwell some time ago? You would be sorry for him then, I am sure."- “ $\mathrm{Ou}$, ay, he was sairly pained wi' rheumaticks; but I'm aye unco' thankful when trouble keeps aff my ain body."

5. Plumularia setacea, Sea Bristles, Ellis. (Plate II. fig. 26.)

Hab. On seaweeds and on shells.

This coralline is more common on the Ayrshire coast than $P l$. pinnata, being at times found in considerable abundance intertwined with the branches of Halidrys drifted ashore. We have occasionally observed it on shells and also on crabs. It sometimes attains the height of six inches, and then it almost rivals the preceding in beauty, but with us it is seldom the half of that height. The finest specimen I have seen was dredged in good company, in Loch Fine, with Professor John Fleming, of Edinburgh, and Mr. Smith, of Jordanhill, aboard his yacht, the 'Raven.' It was not above three inches in height, but the vesicles were thickly clustered along the stem on each side, of a fine red colour, whereas they are generally said to be yellow. Dr. Johnston gives good distinguishing marks betwixt it and $P l$. pinnata. In the latter there are three pinnæ on each internode; in $P l$. setacea there is only one, and it springs immediately 


\section{6.}
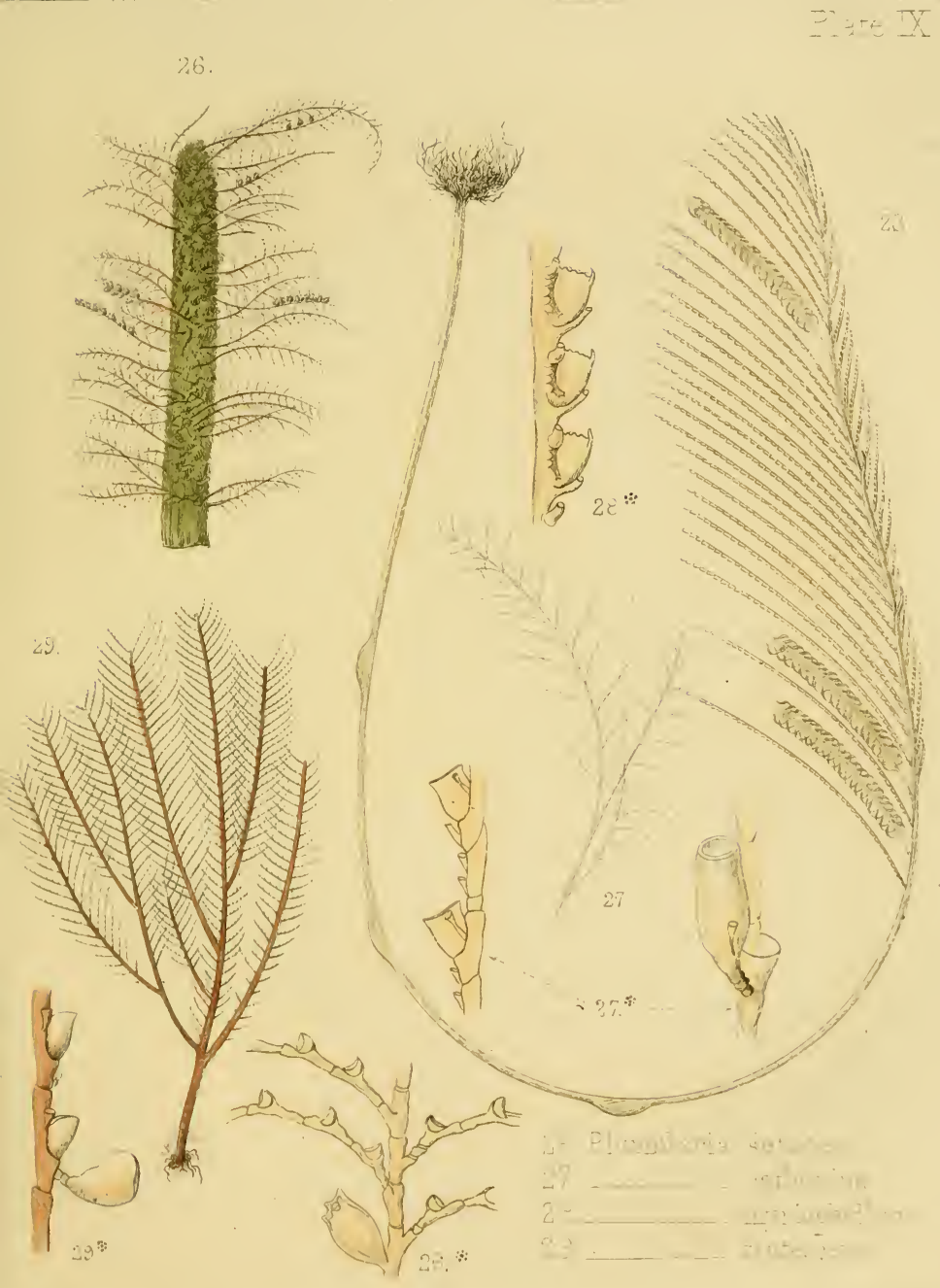
from the joint, which has two or three rings. "The upper part of the vesicles is prolonged into a short tube, affording an additional distinctive character betwixt it and $P l$. pinnata, which it so closely resembles." (Hassall.)

6. Plumularia Catharina, Dr. Johnston. (Plate IX. fig. 27.)

Hab. On old shells, corallines, and Ascidia; deep water. Frequent in Berwick Bay, Dr. Johnston; Scarborough, rare, Mr. Bean; Frith of Forth, Mr. Coldstream; Isle of Man, Prof. Ed. Forbes; Howth and Lambay, Mr. Hassall ; Cornwall, Mr. Couch and Mr. Peach; Aberdeen, Mr. J. Macgillivray; near the Mull of Cantyre, Mr. Hyndman; Lam. lash Bay, D. L.

Dr. Johnston says, "This equals $P l$. pinnata in size and delicacy, but it differs from it very obviously in having opposite pinnæ, which, instead of being arched, bend inwards, so as to render the general form of the coralline concave, on a front view; an appearance produced by the pinnæ originating, not from the sides, but from the anterior face of the stem."

To be convinced of the great beauty of this elegant coralline, we must see itself, or see in Dr. Johnston's work the graceful figure of it furnished by his accomplished 
lady. Te had no small pleasure in seeing it emerging from the deep in Lamlash Bay, Arran. Every right-hearted naturalist will read with interest the following quotation from Dr. Johnston's work:-“To this very distinct and elegant species I have taken the liberty of assigning the Christian name of the lady to whom this work is indebted for by far the greater part of its illustrations;" and to whom, under God, he could have added, he was indebted for much of the happiness of his life. "Ter felices et amplius," etc. Long may they be spared to each other and to their numerous friends; and when their sun at last goes down in mellow beauty, may it be to rise with brighter radiance in a better land.

** Stem composed of many parallel tubes.

7. Plumelaria irriophyluuar, Pheasant's tail Coralline, Ellis. (Plate IX. fig. 2S.)

Hab. Deep water, rare. Near Dublin, Ellis; coast of Devonshire, Dr. Coldstream; on the shore at Ballycastle, Robert Brown; Dublin Bay, Templeton; Youghall, Miss Ball; near Sana, Mr. Hyndman; Belfast Lough, Mr. M'Calla; Cornwall, Mr. Peach ; Aberdeen, Mr. Macgillivray; coast of Angusshire, Mr. Don; near Largs, Mr. James Cunninghame; Lamlash Bay, Arran, D. L. 
"This very rare coralline grows to the height of ten or twelve inches. The root, or first beginning, consists of an irregular tuft of extremely small tubes, appearing like a piece of sponge to the naked eye. Several of these little tubes rising together, and uniting in close contact, become a stalk, which appears in the microscope curiously channeled and indented." (Ellis.) The stalk is generally simple. In the figures by Ellis there is one in which the stalk is once divided near the base. In all our specimens the stalks have been simple, undivided, but composed of a number of tubes, which gives it, when dry, a furrowed appearance. "In each of these furrows there is a row of small holes with a raised brim, as if punctures had been made by an instrument pushed from within. The holes are close-set, and regular in their size, form, and in the distances between them. No probable conjecture of the use of these has been made." (Dr. Johnston.)

In more respects than one, our specimens of this beautiful coralline-this "palma marina," as some of the old naturalists call it-were singularly fine. The usual height is said to be six inches, Ellis mentions ten or twelve. One specimen I got in Lamlash Bay measured eighteen inches from the base to the tip of the plume. One of its general 
characteristics is, that its pinnæ or plumules lean so much to one side (as the fine figures of it by Ellis and Dr. Johnston indicate), that it has somewhat the appearance of being unilateral, and consequently like a feather shorn of its rays on one side. In this specimen the plumules, instead of leaning to one side, proceed uniformly from the stem in opposite directions; and as the plumules on each side of the stem were upwards of an inch in length, and of a silvery colour in the water, handsome feathers were thus formed, fitted to vie even with those in the tail of the beautiful silver pheasant. In one respect they differed from the tail-feather of a real pheasant, - the pinnæ came not to a point, but continued to diverge on each to the top, so that the summit had rather a rounded appearance, approaching that of the peacock feather.

We were going to say, that in a still more important respect it was singularly beautiful, in having vesicles, but we now remember that it was a specimen subsequently obtained that had this distinction. We were much struck with its remarkable appearance, and having observed that it was mentioned in the first edition of Dr. Johnston's 'History of British Zoophytes,' that the vesicles of this handsome coralline were still a desideratum, I sent the specimen forthwith 
off to him, in the hope that what had been lacking was at last found. At page 118 of the second edition, he says, "Since the preceding sheet was printed, I have received from my friend D. L. a specimen of Plumularia myriophyllum with ovaries. These are very peculiar, and unlike any I have observed in any other Sertularian zoophyte. In the ovigerous plumules there arises from the base of the polypecell and on its outer side, a long gracefully curved process; and as all the processes curve round in one direction, they give the pinnule a secund character and habit very different from that of the barren shoots. The processes are alternate, hollow, coarsely denticulated on the external edge; and at their base, opposite the polype-cell, the ovaries are situated. These are didymous, or in pairs, sessile, smooth, resembling a mussel-shell in shape, and easily detached. They differ from the horny vesicles of the Sertularince in texture and in shape, and may best be described as naked ovaries. The spinous process which protects them, appears to be formed by a prolongation of the spine that supports the barren polype-cell."

This remarkable specimen was got by a fisherman, adhering to his long lines, off Whiting Bay, Arran, and being struck with its beauty, like a kind-hearted man, he took it 
home as a present to his wife, and she being a person of similar taste, admired it as much as her husband had done. With all due care, therefore, she planted it in an old teapot filled with earth, and watering it with fresh-water every morning, she had the satisfaction of thinking that it grew a little larger under her judicious management! What would have been her delight had she foreseen that her seaborn, earth-nourished favourite, was to flourish for ages in Dr. Johnston's well-known 'History of British Zoophytes!'

But it was not long without a rival. I soon got another Arran specimen with resicles, and Major Martin got three; and in the summer of 1S51, after a delightful day's dredging off Largs, with Dr. Greville and Mr. James Cunninghame, of Edinburgh, the latter gentleman showed us a magnifieent specimen of $P$. myrioplıyllum rich with vesicles, which a few days before he had dredged of Cumbrae; and it is worth observing, that in this as well as in every other specimen obtained in the west of Scotland, the pinne, instead of inclining to one side, lay flat, diverging equally from each side of the stem.

8. Plumularia frutescexs, Shrubby Coralline, Ellis. (Plate IX. fig. 29.)

Hab. Scarborough, Ellis; at Scarborough, also, Mr. 
Bean, on stones and shells in deep water, rare; Hartlepool, Mr. Hogg; Cullercoates, Mr. J. Alder; Whitburn, Miss Dale; Youghall, Miss Ball; Dublin Bay, very rare, Mr. IIassall; Cornwall, Mr. Couch, not rare; Lady Keith Murray, Stonehaven, Kincardineshire, the first time gathered in Scotland.

Between four and five inches in height, woody, duskybrown, varnished; pirmæ alternate, and each divided into branches; cells smooth; a small cell in the axils of the pinnæ; vesicles scattered, pear-shaped, on the upper edges of the pinnæ.

I have two fine specimens of this rare coralline: one I owe to the kindness of Mr. Bean; the other I had the honour of receiving from Lady Keith Murray, whose scientific eye discovered two or three specimens of it on the north-east coast of Scotland.

"As for your pretty little seed-cups or vases" (writes Hogarth to Ellis), "they are a sweet confirmation of the pleasure Nature seems to take in superadding an elegance of form to most of her works, wherever you find them. How poor and bungling are all the imitations of Art! When I have the pleasure of seeing you next, we will sit downnay, kneel down if you will-and admire these things !" 
"New buds and bulbs the living fabric shoots, On lengthening branches, and protruding roots.

Or on the father's side from bursting glands, Th' adhering young its nascent form expands;

In branching lines the parent trunk adorns, And parts, ere long, like plumage, hairs, or horns."

Darwin's Temple of Nature.

\section{Fanily CAMPANULARIADA.}

Character. Polypidoms plant-like, horny, rooted by a creeping tubular fibre, branched or simple; the polype-cells thin and campanulate, terminal, elevated on a ringed footstalk, disposed either alternately or irregular : ova in horny deciduous capsules. Polypes with a single series of filiform tentacula; the mouth proboscidiform. Embryo medusiform.-Dr. Johnston.

\section{Genus XIII. LAOMEDEA, Lamouroux.}

Gen. Char. Polypidom rooted by a creeping fibre, plant-like, erect, jointed at regular intervals, the joints ringed, incrissated, giving origin, alternately from opposite sides, to the shortly pedicled cells : cells campanulate : resicles axillary. Polypes hydraform.-Dr. Johnston.

1. Ladiedea dichotoma, Sea-thread Coralline, Ellis. (Plate X. fig. 30.)

Hab. On old shells and other bodies within tide-mark. 
Plate X

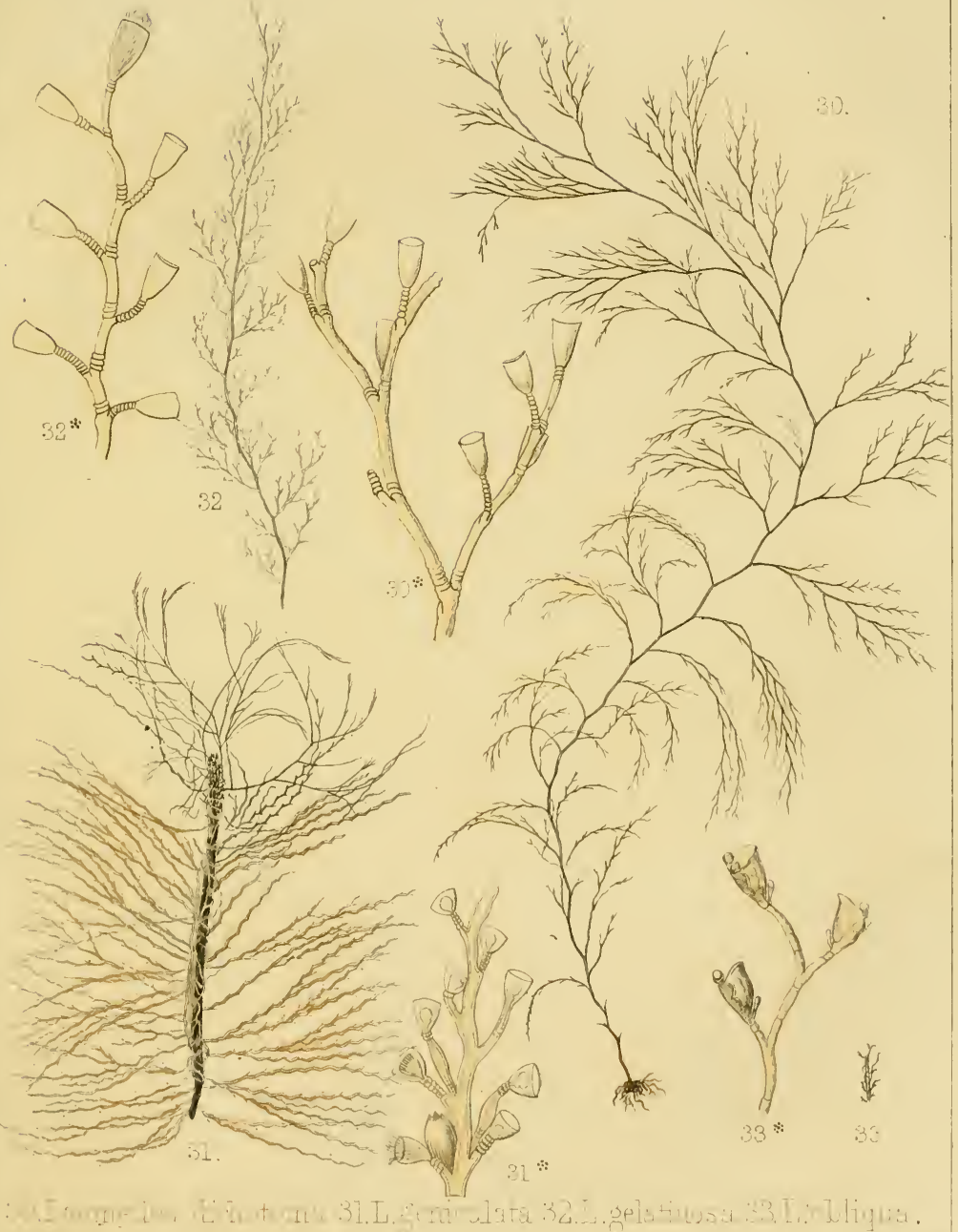


Dr. Johnston frequently finds it on branches of trees that have been carried by floods into the sea.

It rises to the height of a foot, and even two feet. The stem is filiform, zigzag, giving off a short branch from every bend. The cells are bell-shaped, on ringed pedicles, which are about three times the length of the cells. The short-stalked vesicles are axillary and pear-shaped. The polypes are reddish.

It is truly edifying to observe, that He who made all the inhabitants of the world, extends his kind care to even the minutest of them, whether in the air, or on the earth, or in the sea. He has consulted the safety and comfort of this thread-like zoophyte; and it is pleasant to see Ellis observing this._- "This coralline is found in great abundance on the south-west coast of England, and seems most curiously contrived, from its structure, to resist the violence of the waves, all its joints being furnished with springs. Its vesicles also are formed so as to yield easily to every violent impulse of the water without injury, from their being placed on footstalks formed like screws."

It is not common on that part of the Ayrshire coast with which I am best acquainted; but I have fine specimens from Mrs. Griffiths, Mrs. Gulson, Miss Cutler, and Mr. Tudor. 
2. Laomedea geniculata, Knotted-thread Coralline, Doody. (Plate X. fig. 31.)

Hab. On Laminarice, very often on Matidiys siliquosa, and not unfrequently on Chorda filum. "Some of the finest specimens I have seen were growing on the dorsal and caudal fins of a picked dog-fish." (Couch.)

It is interesting to observe how indissolubly the fibrous roots of this coralline are twined round the branches of the Malidrys. And though a person would suppose that it would not be able to fasten itself firmly on the smooth frond of Laminaria, he will find, on trial, that it is 110 easy matter to detach it. The fibres, half-sunk in the frond, "form," as Mr. W. Thompson observes, "a regular piece of network, having meshes of various size, with their junction tied in a knot, as it were by fairy fingers : from each knot, in duc time, the zoophyte springs."

The polypidom is about an inch in height, zigzag, the cells bell-shaped; the vesicles somewhat resemble an urn in form. Several naturalists have observed that this coralline, like several others, is often tinted with red; but it has not been ascertained on what the red colouring depends. We think that we have at times observed that it is a slight film of Melolesia. 
3. Laomedea gelatinosa, Dillenius. (Plate X. fig. 32.)

Hab. On stones and seaweeds between tide-marks. On the under surface and sides of stones, Berwick Bay, Dr. Johnston. On the under sides of stones, in places left dry for hours every tide; and on the under surface of shelving rocks, growing with its top downwards, and left dry every tide, Ayrshire coast, D. L. In the Solway, in such abundance that it is a nuisance, requiring often to be removed from the stake nets, Sir W. Jardine.-With us it is not above an inch in height, but in favourable circumstances it rises to the height of ten inches. The cells are cupped, with an even margin; the vesicles urn-shaped, rising from the axils of the pedicles.

"The base by which it adheres to stones is spreading and spongy, and consists of numerous closely interwoven fibres, which rapidly approach to form the stem." "The polypes are not very irritable, for even when pricked with a needle they seldom retreat completely within their covering, and when left at rest they soon expand themselves." "When in an active state, I have observed the water taken in at the mouth descend, for the space of several seconds, through the gelatinous parenchyma of the body and footstalk, and again return to be ejected. The fluid thus circulating did 
not seem to move in a solid body, but to be divided into minute globules, which permeated a cellular structure."Dr. Fleming.

4. Laomedea obliqua, $W$. $W$. Saunders. (Plate MI. fig. 34.)

Hab. Parasitical on seaweeds; Brighton.

This pretty little zoophyte was sent to me by Mr. Pike, College Gardens, Brighton. He sent me some algax, which he has the art of preparing in a peculiar manner, by which the very finest kinds are made realy for the herbarium unattached to paper, so that when held up betwixt the eye and the light, they look like a beautiful filmy skeleton. It was not for this species in particular he sent the algre, and he had not mentioned it. Observing a very delicate fringe on the margin of $R$. palmetta, I applied my Codington lens to it, and was delighted to see, in its close array of elegant oblique cells, what at once reminded me of Dr. Johnston's, or rather Mrs. Johnston's, excellent figure of Laomedea abliqua. It was first observed at Brighton by Mr. Saunders, and it seems not uncommon there. Unless a person be on the outlook for the "minims of nature," it is apt to escape notice, for the little stems which bear the cells are often less than half an inch in height, and the whole polypidom, 


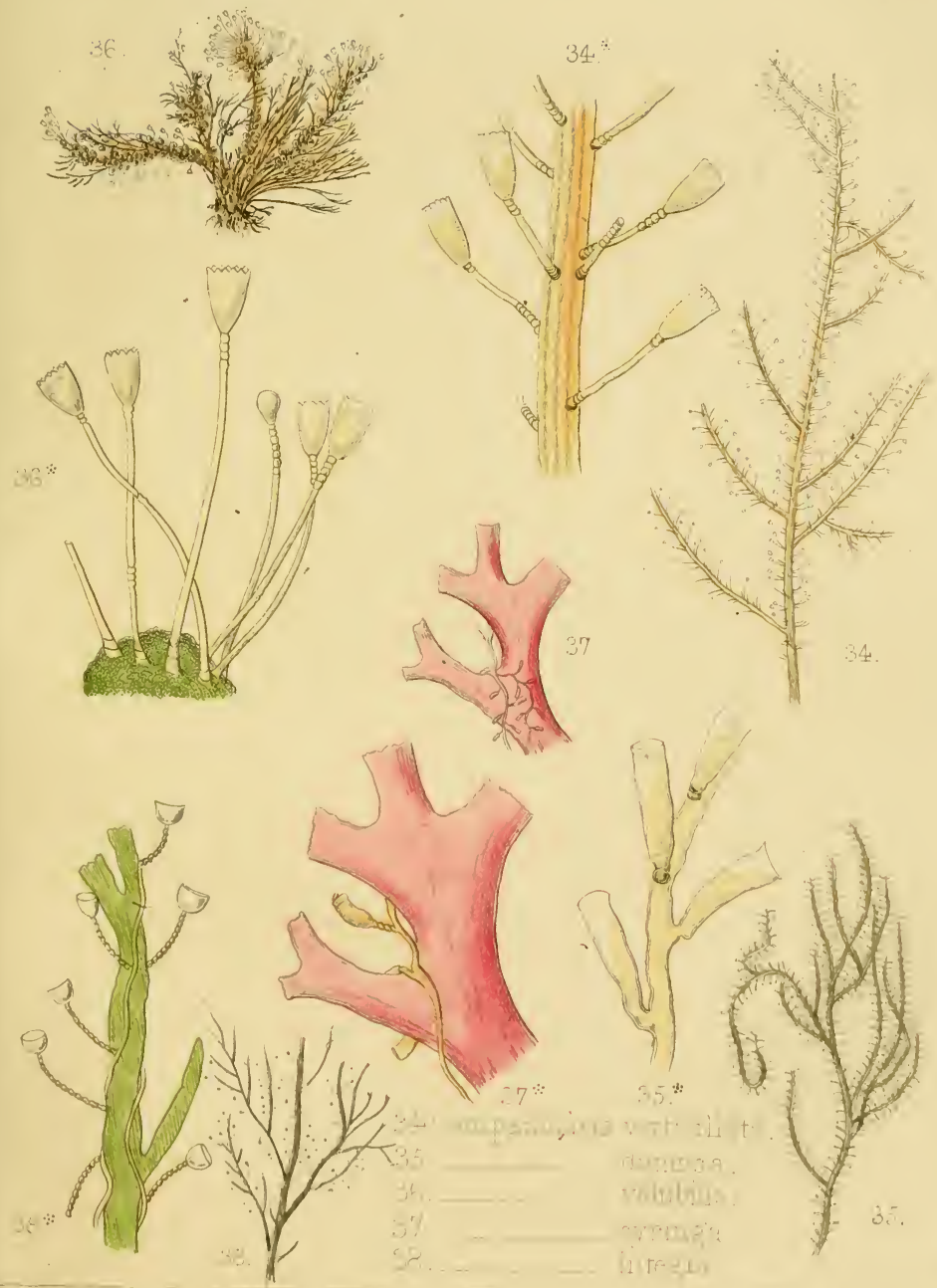


root and branch, has a pale, horny, hyaline aspect. "The stem is divided at regular intervals, as in the other species; but instead of several rings or twists above the origin of the cells, there is a small internodal joint; and the stalk of the cell, instead of being ringed, consists of two or three unequal joints, much as they are formed in the genus Halecium. The cell itself is of the normal thin hyaline texture, and bell-shaped, but the rim is sinuated on the proximate margin, so that the aperture resembles very much the mouth of a jug." (Dr. Jolnston.)

As jugs differ in form, we may mention that it is a jug of the common form, the rim of which is depressed towards the handle, giving the mouth a scooped appearance.

\section{Genus XIV. CAMPANULARIA, Lamarck.}

Gen. Char. Polypidom rooted, creeping, or when compound erect; the main tube filiform, continuous, giving off its pedunculated cells irregularly or in whorls; pedicles ringed, usually long: cells campanulate: vesicles scattered, sessile. Polypes hydraform.-Dr. Jolinston.

$$
\text { * Stem a single tube. }
$$

1. Campanularia rolubilis, Small Climbing Coralline, with bell-shaped cups, Ellis. (Plate XI. fig. 36.) 
Hab. Parasitical on corallines and seaweeds. "This very minute coralline arises from small irregular tubes, which adhere to and twine about other corallines, particularly the sickle coralline. Exceedingly small twisted stalks go out from this tubular stem, which supports little bell-shaped cups with indented brims. At the bottom of each, where they join to the stalks, the microscope discovers to us a very minute spherule or little ball, as in some drinking-glasses." (Ellis.) The stalks are sometimes even and smooth. We were rather surprised, on one occasion, to see the stalks without a ring, quite smooth, and of greater length than usual; but we could account for this on reading the observations of Mr. Couch, "that the animal possesses the power of corrugating the whole," and, consequently, of relaxing the corrugation. It was some time before we observed the vesicles, which are less conspicuous from being sessile, but they are of considerable size, ovate, and wrinkled.

On the west coast of Scotland, it is chiefly found on Halidrys and other seaweeds, though we have seen it on the shell of a crab. Lately, on taking up on the shore a drifted larch branch, we found every twig of it "bearded like the pard" with this little parasite. It is a beautiful microscopic 
object, and we see the Creator's wisdom and kindness in its structure. "This elegant microscopic species is furnished with a delicate joint or hinge, situated at the base of each little cup. This beautiful contrivance is designed, I imagine, to enable this frail zoophyte the better to elude the rude contact of the element by which it is surrounded, by permitting it to bend to a force which it cannot resist." (Hassall.)

2. Campanularia integra, $W . W$. Saunders. (Plate XJ. fig. 3S.)

Hab. Donmonth, parasitical on Tubularia indivisa, J. Macgillivray; Hastings, W. W. Saunders; on stones and shells from deep water, Polperro, Mr. Couch.

"This species, which I believe to be new, differs from the preceding in having cells with the rim entire, and not serrulated as in C.volubilis. With $C$. syringa, the only other British species of the genus which has a single tube for a stem, it can never be confounded; the denser corneous texture, cylindrical tubular cells, and short pedicles of $C$. syringa, are perfectly distinctive." (J. Macgillivray.)

I observed what I regarded as this species, on algæ kindly sent to me by Miss S. Beever of Coniston, which had been transmitted from the Isle of Man; but as the specimens had 
rather suffered in the transit, I shall not attempt to add anything to Mr. Macgillivray's good description.

3. Campaxularia intertexta, R. Q. Couch.

Hab. Parasitical on Sertularina.

This is described by Mr. Couch as differing greatly from the kindred species, and as being like a loose-textured sponge, having minute campanulate cells, with even, truncated apertures. Dr. Johnston speaks doubtfully respecting it.

4. Campanularia syringa, Creeping Bell Coralline, Ellis. (Plate XI. fig. 37.)

Hab. Parasitical on other corallines, and the lesser fuci. After describing C.volutilis, Ellis says there is another species of this creeping kind of bell coralline, which is found adhering to the sea-fir coralline. The difference between them is, that the twisted stalks of this are much shorter, and the cups are longer-shaped, and not indented about the brims. This seems rare on the west coast of Scotland, but we observed it lately on Sertularia argentea, which is also rare with us; we have received it too from Allardyce, Cromarty. Dr. Johnston says, what distinguishes this from every other species, is its operculum-a name which Van Beneden gives to a lid of a conical shape formed by a prolongation 
of the margin of the polype-cell. When folded down or drawn within the cell, the top of this appears truncated.

5. Campanularia lacerata, Dr. Johnston.

Hab. Parasitical on Plumularia falcata, Berwick Bay, Dr. Johnston; and on Cellularia scruposa, at St. Andrew's, Prof. J. Reid.

This little creeping bell coralline seems as yet seldom to have been met with. It is described by Dr. Johnston, "Cells arising from a slender tubular stem, which creeps upon the ramifications of other corallines, scattered, on very short pedicles, consisting of four or five equal rings, ovate, the upper part of a conical form, and divided into six deep lanceolate segments, which, in our specimens, are all connivent, and form an acute apex." Professor Reid states that the tentacula can extend twice the length of the cell, and that they have numerous small tubercles adhering to their outer surface.

** Stem composed of many parallel tubes.

6. Campanularia verticillata, Horse-tail Coralline, Ellis. (Plate X. fig. 33*.)

Hab. Near Whitehaven, Dr. Brownrigg; near Hartlepool, Mr. Hogg; Scarborough, Mr. Bean; Cullercoats,

* In the Plate this is named, by mistake, Laomedea verticillata. 
Mr. Alder; Cornwall, Devon, and Norfolk, Mr. Peach; Hastings, Mr. Tumanowicz; Dublin Bay, Mr. Hassall; Belfast Bay, Mr. W. Thompson; Magilligan, Mr. Hyndman; off the Cumbraes, Clyde, Prof. E. Forbes.

"This curious coralline appears through the microscope to be of the most singular structure of any yet describer. It consists of sundry branches, and every branch is composed of many stout, united, small tubes, which at certain equal distances send off small capillary screw-like stalks, each of which supports a cup of a bell-shaped figure, curiously indented round the brim. These are placed in such a manner as to correspond exactly in point of situation with the others, and to give the whole very much the appearance of the plant called horse-tail, or Equisetum; the capillary stalks and their cups being all disposed in whorls or like branches for candles." (Ellis.) The pedicles are ringed at top and bottom. The resicles which arise from the stem are smooth and short-stalked. The first specimens we had of this were from Mr. Tudor, Bootle.

7. Campanularia dumosa, Pallas. (Plate XI. fig. 35.)

Hab. On rocks and corallines, in deep water.

There are two varieties of this coralline, of both of which we have specimens. The larger is three or four inches in 
height, irregularly branched, and formed of parallel tubes. The other variety makes little show as it creeps along the stem of other corallines, giving off on all sides its trumpetshaped, nearly sessile cells, forming a kind of brown beard on the object to which it clings. Dr. Jolnston remarks that the little polype is shy, and will remain for days in a contracted state at the bottom of its cell. Professor Reid says it is sluggish; and Professor E. Forbes describes it as the most active polype of its tribe he ever saw, starting up and down its cell like one of the Ascidoids.

"Whom Nature's works can charm, with God himself

Hold converse; grow familiar day by day With His conceptions, act upon His plan, And form to His, the relish of their souls." - Akenside.

Tribe 3. HYDRINA.

\section{FANILY HYDRAID五.}

"It is difficult for a thoughtful mind to decide whether admiration is more deservedly challenged by the vast or the minute forms of living existence around us; but the adaptation of both to fulfil the purposes of their being, and the varieties which intervene between the two extremes, cannot 
be carefully observed without a conception the most cxalted of the fertility of the Creating Mind, and the richness of the creation. Evident as was the fact to Lucretius, it is still more open to our observation :-

"Thus Nature varies: man and brutal beast,

And herbage gay, and scaly fishes mute,

And all the tribes of heaven o'er many a sea,

Through many a grove that wing, or urge their song

Near many a bank or fountaiu, lake or rill;

Search where thou wilt, each differs in his kind,

In form and figure differs."

\section{Genus XV. HYDRA, Linnaus.}

Gen. Char. Polypes locomotive, single, naked, gelatinous, subcylindrical, but very contractile, and mutable in form; the mouth encircled with a single series of granulous filiform tentacula.-Dr. Jolinston.

Fresh-water Hydra are so interesting a tribe of Zoophytes, and the properties of which they are possessed are so extraordinary, and have attracted so much attention, that we think it may be acceptable to our young naturalists if we give a bricf history of the discoveries made respecting them. We are the more disposed to do so, as through the kinduess of my excellent friend Mr. Gourlie, of Glasgow, I have at present in my possession a copy in the original of M. Trembley's 
Memoirs, published at the Hague, in 1743, entitled 'Mémoires pour servir à l'histoire d'un genre de Polypes d'eau douce, à bras en forme de cornes;' and also 'Baker's Natural History of the Polype,' published likewise in London, in 1743. What renders M. Trembley's work much more valuable is, that it is illustrated with many plates, and these from the pencil and the burin of the highly celebrated engraver Lyonet. M. Trembley, of Geneva, tells us in his Nemoir, that in the summer of 1740 , when he made these discoveries, he was residing at Sargoliet, the country-house of the Comte de Bentinck, at a little distance from the Hague. Having taken up some water-plants from a ditch, and placed them in a glass vessel, his curiosity was excited by the numerous animalcules with which the water became filled. While engaged in examining them, his eyes casually lighted on a polype attached to a branch of the water-plant; but he paid little attention to it, as, being expanded and motionless, he thought it a little parasitical plant. Please to look at the figure of the expanded IIydra, and you will see the form in which it at first presented itself to him. Looking at it afterwards, he observed some motion in what we now call the tentacula or feelers, but he ascribed this to the motion of the water, occasioned, he conjectured, by the 
little animalcules swimming in it, though the longer he observed them the more he was disposed to question the correctness of this conjecture.

One day he shook the jar in which they were enclosed, to see what effeet it would have on them. The result was very' different from what he expected. Instead of seeing the body and arms agitated in consequence of being disturbed by the motion of the water, the whole suddenly collapsed into a little knob of green matter, and the arms quite disappeared. He was greatly surprised; but his euriosity being increased, he continued to watch them, and while he was observing them with a lens he saw them gradually expand, so as to resume their former appearance. He began then to be convinced that they were animals. The wonder was that he had not sooner been assured of this, for nearly forty years before they liad been deseribed as animals by Leeuwenhoek, and by an anonymous English naturalist, but as their observations had not excited much attention, they had escaped his notice. Nay, even now he was not thoroughly convinced; for though they might resemble slugs that could contract their body and their horns, why might they not be a kind of sensitive plants, collapsing when they were touched? 
After some days he observed several polypes on a part of the glass on which he had not seen them before; and his attention being directed to them for some time, he saw that they could change their position, and that they actually moved from one place to another. This they did somewhat in the way of certain caterpillars, whose mode of walking is to bring the two extremities of the body close to each other, while the middle part is raised like a bow, and then moving the head part, and bringing up the posterior part close to it, by every step they thus advance nearly the length of the body. The polypes made progress in much the same way, by using their arms. Seeing, then, that they could walk, he was, at the moment, persuaded that they were animals, and for some time he paid little attention to them.

The glass in which they were kept was placed on a table near to the window, and passing it one day, he observed a great number of the polypes on that part of the glass which was nearest to the light. Wondering whether this was accidental, he turned the glass half round, so that the lightest part thus occupied was remored into the shade, and the part now exposed to the light was without any upon it. Next day he observed that some had removed to the part that was now most exposed to the light, and in a few days 
they had all taken up their position there. He repeated this experiment so often, that he was thoroughly convinced that they preferred the lightest part.

In continuing his observations, the idea again recurred that it was still possible that the body and the arms might be branch and roots of some little aquatic plant, and to satisfy himself he had recourse to the following experiment. He divided a polype into two, cutting it transversely, saving, that if both lived, and became perfect polypes, he would conclude that they were plants. A person might have thought that he would from this have concluded that they were animals; but being more disposed to regard them as animals, he expected that both pieces would die. He placed a polype in a shallow plate and cut it across, and the moment he-did so both pieces contracted so as to become like little green grains. The same day, however, they both expanded, and he could easily distinguish the one from the other, as the one which had the head and arms was a little longer than the other, which had neither head nor arms, and which he regarded as the tail. But extension was not the only sign of life given by the larger one; he saw it move its arms, and by the use of its arms he saw it change its place. On shaking the glass, both of them contracted, 
and soon after expanded; but this he regarded as only the feeble remains of life in the one; in the other, which had the head and arms, he began to think that the round he had inflicted might not be deadly; that being only mutilated and deprived of a part that was not vital, it might recover, as he had seen lizards do when they had lost their tails. He continued, however, to observe the other part, to see how long it would retain symptoms of life, but not with the slightest expectation that it would recover its head and arms. Great was his surprise, then, when on the ninth day after the polype had been cut in two, regarding with a lens the tail part, he saw three little points precisely at the place where the arms would be if it was to become a complete polype. He became quite excited, and very impatient for the moment when he would be able with certainty to know what they were. He had not to wait long, for next day they were so much longer, that he could not entertain a doubt that they were arms that were growing on this smaller section of the polype. The next day there were two more, and on the following day three additional, making in all eight arms, which were soon as long as those on the entire one, or on the part which had the arms before the body of the polype was divided. In a little while each part had 
become as complete a polype as one that had never been cut : they expanded, they contracted, they moved from place to place.

Still he was not satisfied, and he continued to sturly them, in the hope that he might discover some other properties. According to what he proposed, when he made the experiment of cutting them, he should now have concluded that they were plants, as the two cuttings or slips had produced two perfect polypes; but from the spontaneity of their movements he was rather disposed to regard them as animals. As yet he did not know how they multiplied; and having a great number of them in a vase together, his attention was turned to this. At last he discovered one about to produce a little one. At first it was like a small green bud on the body; it rapidly increased in size, sent forth arms, or tentacula, as we shall now call them, and dropping off after some days, became an independent polype. Was he now convinced that the polype was an animal? No; this resembled the increase of plants by offsets, and he thought still that the polype might be a plant, or rather an animal plant, holding a middle rank betwixt the two, partaking of the nature of both. While he was in this state of doubt he sent some of them to Paris, to the distinguished naturalist Réaumur, and 
soon after he had the satisfaction of hearing from him that they had arrived alive; that he had examined them, and hesitated not to rank them among animals; and this put an end to M. Trembley's doubts.

Though he ceased to doubt as to their animal nature, he ceased not to carry on his observations, particularly as to their mode of multiplication. He thought he ascertained that this is sometimes by eggs, which, when emitted from the body of the polype in autumn, sink into the mud, in which they lie during the winter, to be transformed into polypes when the vernal sun shines forth on them. He observed also, on several occasions, that a polype became divided into two, that at first there was a stricture about the middle of the body, that the division took place at this stricture, and that, before separating, the tail part had acquired tentacula, and was thus prepared to support itself as independent. Far more frequently they multiplied by buds, as we have already said; and he gives a particular account of his observations as to this mode of multiplication. At first there was a little gemmule on the cylindrical body of the green polype, chiefly observable by its darker colour. In a day or two it had projected from the parent polype about a line; in a few days, when it had still more increased 
in length, it began to get tentacula. Till it got tentacula, it was altogether dependent on the mother for support; and it could be seen that the food which was introduced into the stomach of the parent, made its way at the point of junction into the stomach of the little one. As soon, however, as it had got tentacula, it caught prey for its own support, and helped also to support the mother; for by the application of a lens, he saw that the red worm, for instance, which it caught and devoured, passed, in part, the point of junction, and entered into the stomach of the parent. Here the young have a lesson taught them, that they should early learn habits of active usefulness, and that they should seek to add to the comfort of their parents; but though this is taught, truth constrains us to confess that the young polype does not always willingly practise the duty; for mother and daughter sometimes lay hold on the same prey, and it is only by superior might that the little one is forced to yield it. When the young one has got its full equipment of tentacula, its body becomes attenuated at the base, where it is joined to the older one, so that they are connected only by a slender point, and by mutual consent they seem disposed to part company. To effect this they fasten themselves by their tentacula to different parts of the 
plant or glass, and bending their bodies in opposite directions, they are easily torn asunder.

Their food consists of various little animalcules and infusory animals, and they are particularly fond of a very minute red worm. Their tentacula are generally waving about in all directions; and though they have no eyes, it has been observed that when any little hapless wanderer approaches one of the tentacula, it makes a sudden motion in that direction and lays hold of it. And alas for the little wight who is thus apprehended! It is all over with him: there is such venom in the fangs of these little Hydre, that the touch of one of their tentacula is deadly. The little worm that is seized may give a few convulsive struggles, but it soon dies. Even though rescued from the fatal grip, death almost immediately ensues. Fish, it is said, seem aware of their poisonous quality, and do not feed on them. And yet the effects of their poison are not felt in their contests with each other. It sometimes happens that two lay hold on the same worm, and try to tear it from each other. The worm may break, and then each has its share. If it break not, they swallow at different ends till their mouths meet. Then comes close conflict and the tug of war. What is to be done? They pause for a little, as if aware of the tremendous 
crisis, and the larger, making a wide mouth, swallows the smaller one, worm and all. You would imagine that he who has been swallowed by an enemy whose very touch has so often proved deadly, might be numbered with the dead, and would never appear on the field again. Point du tout. Watch the victor for a little, and you will find that ere an hour elapses he again opens his wide mouth, and disgorges from his greedy maw his imprisoned victim, minus the worm, which the conqueror has by this time digested, but otherwise unscathed, and as ready as ever to pursue his prey, and to assert his right to it when it is captured!

M. Trembley learned, in the course of his observations, that these little Iydra are very prolific. When the temperature was mild and nourishment abounded, a single polype produced about twenty offsets or young ones in a month. But then these twenty form not the whole product, for every one of the young ones, when disjoined, becomes as fertile as the mother. Nay, it very often happens that they begin to be prolific before they are separated from the mother; and as the mother rolype has several offshoots appended to her at the same time, and they also may be each yielding offspring, she is thus laden at once with two generations,-mother and children and grandchildren fastened together and appearing like a little branching shrub. 
Having thus given a meagre digest of these interesting memoirs, so beautifully illustrated by the engravings of Lyonet, we may add, that we can scarcely have any idea now of the great interest which this subject excited then throughout the whole of Europe. Nor did it cease to be regarded as important after it had become familiar, for the justly celebrated Cuvier speaks of Trembley of Geneva as "immortel par la découverte de la réproduction du polype ;" and says, moreover, that he acquired "une réputation universelle par sa découverte extraordinaire, qui changeait, pour ainsi dire, toutes les idées qu'on avait eues sur la physiologie et l'anatomie animales." Trembley's experiments and observations were soon repeated and verified by the distinguished naturalist Réaumur, at Paris, and by other naturalists of note in different countries, and among others, by Henry Baker, Fellow of the Royal Society of London, from whose 'Natural History of the Polype,' published in 1743, we shall briefly extract some additional information on this subject. His work is in the form of a letter addressed to the President of the Royal Society; and he begins by saying, "The accounts we have been favoured with from abroad concerning the little creature called a polype, have appeared so extraordinary, so contrary to the common course of nature and 
our received opinions of animal life, that many people have looked upon them as ridiculous whims and absurd impossibilities. In order, therefore, to set this matter right, I beg you will give me leave to lay before the public some observations and experiments on this creature, made with the utmost care and attention, before several persons of unquestionable credit and discernment, and written down from time to time with the strictest regard to truth."

He confirms all that had been recorded respecting them by Trembley and Réaumur, illustrating his statements with numerous woodcuts, which, though coarse when compared with the exquisite engravings of Lyonet, answer, nevertheless, the purposes for which they were intended. He gives one figure of the little creature suspended from the surface of the water by its expanded tentacula, and another figure of it suspended from the surface by its tail, both very common positions, which He who made it taught it how to assume by allowing either the tentacula or the tip of the tail to get dry in the air, and then these dry parts keep above the surface of the water, on the same principle as a dry needle, though of greater specific gravity, if laid cautiously on the surface of the water, wiil not sink, but float. In another figure we see a polype attached by its base to the side 
of the glass, with its body and its tentacula extended, in which position it is " as vigilant as a spider in the centre of its web, fully intent on prey, and will seize a worm with as much eagerness as a cat catches a mouse."- "I have often seen them thus situated, extending and waving their arms in the water, several inches long, and so exquisitely slender as not to exceed the thickness of the finest cobweb; yet their sense of feeling is so delicate, that if a worm touches even the utmost extremity of these very slender arms, they immediately lay hold of it, and, contracting themselves to about the middle length, by clasping their arms about it, they envelope and fetter it in so many places, and to such a degree, that notwithstanding it be much larger, and seemingly stronger, it is soon rendered incapable of struggling to any purpose." " "Tis a fine entertainment to behold the dexterity of a polype in the mastering its prey, and observe with what art it evades and overcomes the superior strength or agility thereof. Many times, by way of experiment, I have put a large worm to the very extremity of a single arm, which has instantly fastened on it with its little invisible claspers. Then it has afforded me inexpressible pleasure to see the polype poising and balancing the worm, with no less seeming caution and judgment than a skilful angler 
shows when he perceives a heavy fish at the end of a single hair-line, and fears it should break away. Contracting the arm that holds it by very slow degrees, he brings it within the reach of his other arms, which eagerly clasp round it, and the danger of losing it being over, all the former caution and gentleness is laid aside, and it is pulled to the polype's mouth with a surprising violence. The worm, on its part, is not without a knowledge of its enemy. The moment it touches a polype's arm, it starts away, with as much seeming horror as a man would do that should tread upon a snake or some other dreadful creature."

Nearly a hundred pages of Mr. Baker's book are oceupied in giving an account of experiments made by himself and a friend, to show how greatly the polype may be multiplied by being cut in pieces. He secms to have had greater pleasure in experiments that savour of cruelty than I trust any of my young friends have; but seeing that these experiments, as performed by Trembley, were regarded, as we have seen, by Cuvier, as giving us new views of physiology and anatomy, and as they bring before us the cxtraordinary properties of this little animal, that have made it so peculiarly interesting to the scientific world, we must not pass them over without a bricf notice. 
"What kind or degree of pain," Baker remarks, "this creature feels upon being divided, it is impossible to conceive or know ; but we commonly find that the parts contract themselves immediately after the operation, and a sort of tremor or quivering motion may frequently be observed in them by the microscope. And yet its eating so soon after it has been cut asunder would almost induce one to imagine, either that the pain is not very great, or that it is over instantly, or that the pain of hunger is greater."

Were those who make these experiments to be accused of cruelty, they might, perhaps, say that the seeming cruelty is greatly overbalanced by the results; for though they do inflict pain on a single animal by cutting it into fifty pieces, as M. Trembley has at times done, this pain, at the longest, is only of a few days' continuance, and after that you have fifty times the original amount of happiness, for instead of one, you have fifty living creatures as full of enjoyment as had been the single polype from whose mangled body this great troop has sprung.

The first experiment that Baker records is the cutting off the head of a polype close under the tentacula. This he did on the 25th of March. He made observations on both the parts every day. There was daily progress in both, and 
by the ] st of April the head part had got a new body, seemed strong and vigorous, and in no respect differed from other polypes of its kind. About the same time the tail part began to show little tentacula, and a young polype began to spring from the middle of its body. Slimy matter, however, enveloping the part where the new head was beginning to be formed, he beheaded it a second time. On the 7th of April, new tentacula were observed round the part from which a head had twice been cut, and there were three young ones in a thriving state on different parts of the body. On the 8th of April the tentacula were so much grown, that they could lay hold of a worm, which the polype greedily devoured; and on the 9 th of April, as it seemed now complete, he ceased to observe it and its young family. He afterwards divided a polype into four parts, and these in a few days were transformed into four polypes. He likewise cut in two some of the young ones before they were separated from the old, and the part that remained attached soon recovered what it had lost, and the amputated part grew into a perfect polype.

His next experiment was to cut a polype lengthways into two equal parts, both as to the portion of the body, and the number of tentacula, which each part retained. Being 
divided from head to tail, the body no longer formed a tube, but in each of them was open the whole length on one side. Both parts, after being cut, lay in a state of collapse for about half an hour. The next day each was standing upright, and spreading out its remaining portion of tentacula, and they ate right willingly a worm given to each of them. By the fourth day the wound, seemingly so deadly, was healed, and each was again tubular, and tentacula had begun to grow, to make up for those that were lacking; and in a day or two more each formed as complete a polype as those that had never been subjected to the sharp work of the scissors.

In the next experiment he was not quite successful. It required very delicate management, for it was nothing less than turning a polype inside out. A person would naturally have thought, that to any creature this would be completely ruinous, - that it would be quite impossible for any animal to survive under such an operation as turning it inside out, as one would do a glove or stocking. Yet M. Trembley gives us a detailed account of the ingenious manner in which he accomplished this, and, what is wonderful, that the polypes did not seem to be injured by it. It was plain, however, that they did not much like it, that they preferred 
their original arrangement, for they endeavoured to return to it, and being at times successful in their efforts, they were again found in statu quo; but as this did not suit the fancy of the operator, he fell upon means of preventing them from undoing his work, and after a short trial of this novel condition, they seemed quite satisfied with it, devoured their prey as greedily as ever, yielded young ones as before from their polype-bearing bodies, lived to a good old age, and died surrounded by their offspring to the fourth or fifth generation.

"Rerum natura nusquam magis quam in minimis tota est."

Plin. Nat. Hist.

"Art thou proportion'd to the Hydra's length, Who by his wounds received augmented strength ?

He raised a hundred hissing heads in air;

When one I lopp'd, up sprang a dreadful pair;

By his wounds fertile, and with slaughter strong,

Singly I quell'd him, aud stretch'd dead along."-Ovid. Metam.

1. Hydra vinidis, the Green Hydra. (Plate XII. fig. 39.)

Hab. In ponds and ditches, on aquatic plants.

Baker states, that the arms of the green Hydra are so short that it cannot clasp round a small worm, but can only pinct. 


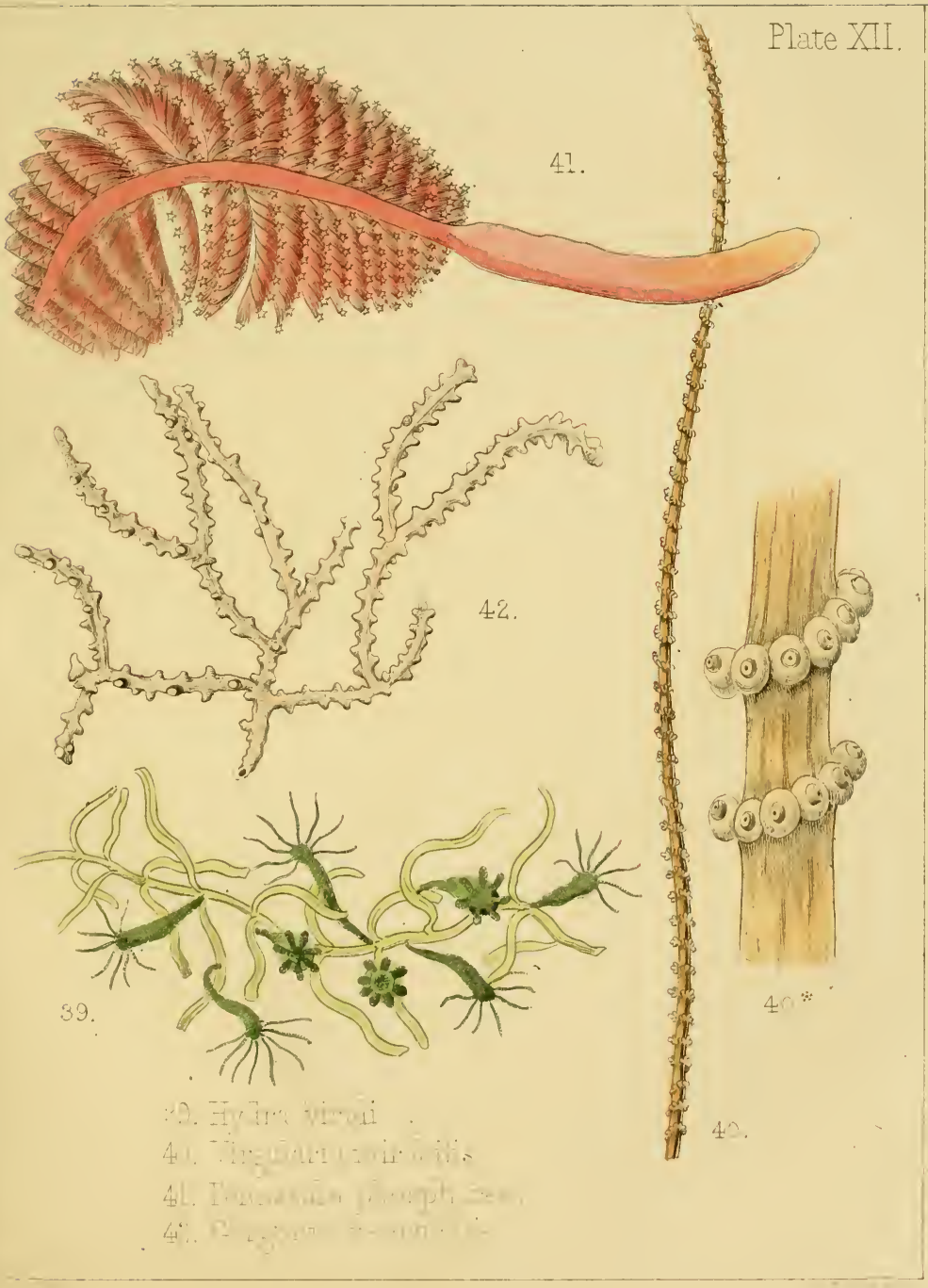



it fast till the polype can master and devour it. This is by far the most common Hydra in the west of Scotland. It is so common, indeed, that if in summer or autumn you take up at random a handful of duckweed or pond-weed (Lemna or Potamogeton) from a ditch or stagnant pool, and put it in a glass vase, you are almost sure to see that you have captured several green $H_{y} d r a$. Their tentacula, however, though not some inches long, like those of other species figured by Trembley, can be extended by the creature so as to be fully the length of the body. "I imagined those polypes owed their green colour to some particular food, such as weeds, etc., and that they would lose it upon being kept to worms; but I find myself mistaken, for they retain their greenness after some months as well as ever, and are now grown of a moderate size, extending sometimes threequarters of an inch; their tentacula are also lengthened very much to what they were, and are of a lighter green than the body, their number, eight, nine, or ten. The tail is very little slenderer than the body, but more spread at the end than the tails of the other kinds." (Baker, 1743.) Pallas says, that the offspring are produced from every part of the body. Blainville thinks he has remarked that they spring always from the same place, though he owns that 
Professor Tan der Hoven thinks otherwise; and so does Dr. Johnston, and so also, may we add, do we, and we have seen more than one young one on the body at the same time, not at Blainville's "point de jonction de la partie creuse et de celle qui ne l'est pas," but one of them nearer the tail, and the other nearer the tentacula.

\section{Hydra vulgaris.}

Hab. Ponds and slowly runuing streams.

This is about the same size as H. vividis, which it also resembles in form, but it differs from it in colour, being of an orange colour, or sometimes more of a brown or even bright red tint, the brightness of the tint depending on the nature of the food. The tentacula are rather more numerous and longer than in the former.

3. Hydra attenuata, Dr. Johnston.

Hab. Ponds, Yetholm Loch, Roxburghshire, Dr. Johnston.

" $\Lambda$ larger animal than the former, and comparatively rare, less sensible to external impressions, and of a more gracile form. Its colour is a dilute olive-green, with paler tentacula, which are considerably longer than the body, and hang like silken threads in the water, waving to and fro, without assuming that regular circular disposition which they commouly do in $I$. viridis." (Dr. Johnston.) 


\section{Hydra oligactis.}

Hab. Still waters, in England, rare; Hackney, Ellicot; Cranmore, near Belfast, Templeton.

"The tails of these are long, slender, and transparent, and when placed before the microscope, a long straight gut may plainly be distinguished passing from the body-part or stomach, to an opening at the end thereof. These are rather lighter-coloured than the former (H. vulgaris), and have seldom more than six or eight arms, but these capable of great extension." (Baker.)

Dr. Fleming regards the above-mentioned species as varieties of Hydra vulgaris; he remarks, "The reproduction of this singular being by buds issuing from the sides of the parent polype; acquiring tentacula, and then falling off and becoming independent individuals, or by the regeneration of parts when artificially divided; has long engaged the attention of the curious observer. The animals may be easily procured by placing a quantity of the stems of plants growing under water in any slow-running ditcl, in a basin of clean water, and in a short time the polypes will expand, and exhibit themselves readily to the naked eye." And yet how few have tried to see them! 


\section{ANTHOZOA ASTEROIDA.}

"There is a magic-like attraction in

Thy waves; thou hast in thee the life-

The eternal, graceful, and majestic life

Of Nature, and the natural heart

Is therefore bound to thee with holy love."

" Old Oceau was,

Infinity of ages ere we breathed

Existence.-And he will be beautiful

When all the living world that sees him now

Shall roll unconscious dust around the Sun.

Swelling, from age to age, the vital throb

In human hearts, Death shall not subjugate

The pulse that swells in his stupendous breast,

Or interdict his minstrelsy to sound,

In thundering concert with the quiring winds;

But long as man to parent Nature owns

Instinctive homage, and in times beyond

The power of thought to reach, bard after bard

Shall sing thy glory, beatific Sea."-Campbell.

THE following is Dr. Johnston's arrangement of the families and genera of Anthozoa asteroida:-

Family I. Polype-mass free, pennated, carnous; the skin spiculiferous; the axis bony, simple, continuous; polypes arranged along the margin of the pinnæ. PeNNATULIDE. 
Polypes on bipennated wings.

Polypidom plumous. Pennatula.

Polypidom virgate. Virgularia.

Polypes unilateral, sessile.

Polypidom linear, elongate. Pavonaria.

Family II. Polype-mass fixed, arborescent; the axis covered with a thick cretaceo-gelatinous celluliferous crust; polypes scattered over the whole surface. Gorgoniade.

Cells for the polypes immersed. Gorgonia.

Cells subpedunculated, protruded. Primnoa.

Family III. Polype-mass fixed, coriaceous or somewhat carnous, without any distinct axis, but strengthened by variously-disposed calcareous spicula; polype-cells subcutaneous, scattered over the surface. ALcyosides. Polypes aggregate. AlCyonium. Polypes segregate. SARCodictYon.

\section{Family PENNATULID瓜.}

Genus XVI. PENNATULA, Cavier.

Gen. Char. Polype-mass free, plumous, the shaft subcylindric, naked beneath, pennated above; pinnæ two-ranked ; spreading, flattened, and polypiferous along the upper margin.-Johnston. 
1. Pexpatula phosphorea, Sir Robert Sibbald. (Plate XII. fig. 41.)

Hab. In deep water. Near Aberdeen, Ellis; Hebrides, M'Andrew ; Zetland, Prof. Forbes ; Leith, Dr. Coldstream ; near Musselburgh, D. L., jun. ; off Saltcoats, and in Lamlash Bay, D. L.

The names given to this zoophyte are very appropriateCock's-comb, Sea-pen, and Sea-feather. Cock's-comb, the name given to it by fishermen, is expressive of its appearance as to colour and substance; Sea-feather, or Sea-pen, however, is more expressive of its form, for the stem resembles the quill, and the upper part, which bears the polypes, resembles the feathery part of the pen. Lamarck says, "Il semble, en effet, que la Nature, en formant ce corps animal composé, ait voulu copier la forme extérieure d'une plume d'oiseau."

It is generally from two to about four and a half inches in length, though Dr. Fleming states that at times it is eight inches long. The stem forms about half of the length. It is all of a reddish colour, except the point of the stem, which is yellowish, and bent a little upwards, like a shepherd's crook. The stem contains a whitish bone, which seems intended to strengthen it, though it is very slender 
in proportion to the size of the stem, which is about the third of an inch in diameter. The breadth of the lobed or feather part is about an inch and a half. There are several polypes on each lobe,-in all, about thirty. It is rare in England and in Ireland, but in the north of Scotland it is frequently found on the fishermen's lines when baited with mussels. In the Frith of Forth it is common. Sir J. G. Dalyell, who describes and figures it admirably, had sixtyfour live specimens at once in his possession. He states that, "like other asteroid zoophytes, it is strictly a nocturnal animal. It enlarges remarkably as evening comes on. It is then that the lobes are swollen, and the hydræ most amply displayed in vigour, while the whole variable organic structure expands by intumescence."

Whether it can swim about, or remains fixed in the murl or sand, is a disputed point. There is high authority in proof of its natatory powers. Bohadsch says that it swims freely, and that he has seen it do so, using its pinnæ for this purpose as fishes do their fins. Ellis says "it is an animal that swims freely about in the sea," and that this is effected by means of feather-like fins. Cuvier tells us that it has the power of moving by the contractions of the globe part, and the combined action of the polypes. Other na- 
turalists of note deny that it has this power. Lamarck and Schweigger, reasoning from analogy, deny it, and Dr. Jolmston, speaking from observation, states that, when placed in a basin of sea-water, they are never observed to change their position, but they remain on the same spot, and lie with the same side up, just as they have been put in. Sir J. G. Dalyell, who at various times has had so many living specimens, states, "Further than complete distension of the whole specimen, whereby its dimensions may be quadrupled, no approximation to motion is betrayed. Neither does such distension, though to the utmost, reduce its specific gravity sufficiently to produce an equilibrium with the water. Thus the animal cannot swim." We have had two or three fine live specimens, which we kept in sea-water for several days. They increased greatly in size, blowing themselves up, expanding their lobes, and spreading out their tentacula from a kind of sheath that covers them when contracted. We were on the watch for some locomotion when the several parts were so swollen, but when laid on the bottom of the jar they could not elevate themselves, nor turn the polype-bearing side of the lobes up if placed with their face downwards.

We did observe, however, that they were phosphorescent, 
and that when roughly touched in the dark, a transient gleam of light was emitted. A very interesting statement as to this phosphorescence may be found in Dr. Johnston's 'History of British Zoophytes,' from which we shall extract only a little. From experiments made by himself and Professor E. Forbes, and others, they were led to infer, first, that the polype is phosphorescent only when irritated by touch; secondly, that the phosphorescence appears at the place touched, and proceeds from that to the extremity of the polypiferous portion; thirdly, that only those parts above the place touched give light; fourthly, that the light continues longest from the part touched; fifthly, that sparks of light are sometimes sent out when the animal is pressed, and these were found to arise from ejected spicula.

\section{Genus XVII. VIRGULARIA, Lamarck.}

Gen. Char. Polype-mass free, linear-elongate, supporting, towards the upper extremity, sessile lunate lobes, enbracing the stem obliquely, and bearing a row of cèlls on their margin.Jolinston.

1. Virgularia mirabilis, Sea-rush, Mir. Simmons. (Pl. XII. fig. 40.) 
Hab. Off Inch Keith, Mr. Simmons; Preston Pans, Prof. Jameson; north and east coast of Scotland, Prof. Fleming; Gairloch, Mr. Smith, of Jordanhill ; near Oban, Mr. M'Andrew ; Belfast Lough, Mr. 'Templeton, Mr. Paterson, Mr. M'Calla.

Dr. Fleming thus describes it: "Body linear, supporting, towards the upper extremity, sessile, lunate lobes, embracing the stem obliquely, and bearing a row of cells on their margin." "These lobes resemble a crest, embrace the side of the stem and a portion of its front obliquely, and terminate in a recurrent manner, the point of the one meeting with the bend of the higher one from the opposite side."

Of this I have a dried specimen from my generous friend Mr. Smith, of Jordanhill, to whose kindness I have often been greatly indebted, and in whose yacht I have had many pleasant excursions. I have also a specimen, preserved in spirits, from my steady and obliging friend Mr. William Gourlie, of Glasgow. It is beautiful, and yet from quotations which I shall subjoin, it will be seen that it gives but a faint idea of the surpassing beauty of the living creature. My friend Mr. R. Paterson, of Belfast, says, beautiful as Müller's figure is, it does not do justice to the living appearance of the animal. 
Sir J. G. Dalyell says, " We have had already some singular examples of conformation and properties among the rare and remarkable animals of Scotland; but I know not that any of the whole is more entitled to be distinguished than $V$. miratilis, now before us, whereof every naturalist, enjoying the enviable prerogative of personal experience, has expressed the highest admiration. The Virgularia in vigour bears a considerable general resemblance to a feather, much more than to a rod or rush. It consists of a long, slender, round shell or bone, invested by a fleshy coating, which expands from each side into a number of lobes, also fleshy, bordered by several asteroidal hydræ." Mr. Paterson describes these lobes, which are translucent, as being rendered more beautiful by about eight delicate lines, more transparent than the adjoining parts; and the lobes as being so unlike each other, notwithstanding the general similarity, that a young lady who was making a drawing of them, when she raised her eyes from the paper to look at the animal, never found a moment's hesitation as to what particular plume she was depicting.

Sir J. G. Dalyell, who has had the advantage of examining some remarkably fine specimens in a living state, remarks, "The Virgularia, for the most part, is procured in 
portions four, five, or eight inches long, with the central bone protruding from one of its extremities, denoting its mutilation. But these are only fragments. The largest I have ever had, extended twenty-three inches in length, nor was this a complete specimen ;" and he concludes, for rea. sons assigned, that this specimen must have extended at least thirty inches. "In its greatest breadth a fine specimen expands about an inch between the opposite hydræ, terminating the extremity of the lobes. The whole is of a beautiful straw-colour, presenting an object whose interesting appearance can be sufficiently appreciated only by beholding the living creature in vigorous display of all its parts."

It is generally thought that the Virgularia fixes the lower extremity in the mud, and keeps itself in an erect position, though Sir J. G. Dalyell has doubts of this. It is questioned also whether it has any power of locomotion. When kept in a jar, it does not change its place or general position; yet the fleshy body can twist itself in a spiral manner around the longitudinal bone, and having done so, it can again relax into a straight line. The bone is remarkably slender: "probably the diameter of the bone of a full-grown specimen is not above the thousandth part of the length. 
Nothing enables us to indulge the slightest conjecture of its use. We can hardly allow its protective utility, for it seems scarcely calculated for supporting itself." In other respects there are mysteries in this beautiful creature, which the most acute naturalists have been unable to fathom. "Each organ," says Sir J. G. Dalyell, "of this remarkable object, has a distinct action, free of all the other parts. Fach lobe, each hydra, each of the pectinate tentacula, and each of their prongs, can move at will, while the whole of the rest of the zoophyte is quiescent. Therefore, in a specimen with the bone extending eighteen inches, above a million of separate fleshy parts are under the common control of the zoophyte." "But how this control is exercised, or how its effect is imparted, is not easily explained. The flesh of the Virgularia enjoys some peculiar power of winding as a spiral around the central bone, while thousands of hydræ, independent so far as to testify individual action, are incorporated with it. What a marvellous work of the creation!"

"These are thy glorious works, Parent of Good,

Almighty! Thine this universal frame,

Thus wondrous fair; Thyself how wondrous then!

Unspeakable, who sitt'st above these heavens,

To us invisible, or dimly seen 
In these thy lowest works; yet these declare

Thy goodness beyond thought, and power divine."

\section{Genus XVIII. PAVONARIA, Curier.}

Gen. Char. Polype-mass linear-elongate, quadrangular. Polypes sessile, retractile, arranged subspirally on one side only of the posterior half of the rachis. Tentacula with intermediate spinules.-Dr. Jolinston.

1. Pavonaria quadrangularis, Mr. M'Andrew.

Hab. West of Scotland, Mr. M'Andrew; near Oban, Mr. William Keddie.

This is a very extraordinary creature, dredged in our Scottish western sea, by Mr. M'Andrew, of Liverpool, who has added so much to our British fauna. There is only one locality, as yet, in which it has been got in this country - off the island of Kerrera, near Oban; and the exact place can be so distinctly described, that my esteemed friend, Mr. W. Keddie (to whom I have often been greatly indebted) having got a description of the locality before setting out for a short residence at Oban, went to the very spot, and dredged it in considerable abundance. I can assure my friends that if they choose as fine a day as I was favoured with the first time I sailed from Crinan to Oban, and on to 
Fort William, amidst the magnificent scenery of the Highland Isles, they are in some danger of forgetting even the submerged Pavonaria, and the thousand wonders of the mighty deep. It is, however, a wonderful creature. Many of our zoophytes are sufficiently minute, and require microscopic aid ere we can be enraptured with their beauty: but this is a giant-a Goliath of Gath-a marine Saul amidst the pigmean people, a living rod of four feet in length, thickly beset with living buds and blossoms. The Neapolitan fishermen call it penna del pesce pavone, the pen or feather of the peacock-fish,-hence the name Pavonaria. Without going so far as Naples, however, we shall. give the following, as part of the description of our Scottish Paronaria, by Professor E. Forbes:- "The whole rod, when alive, invested with a fleshy skin, is very slimy. Its base or root is cylindrical, of a yellow colour, and terminating somewhat obtusely, and bulbous. The lowest polypes on the rod are very small, and in a single row on each side, but they gradually increase in size, and become more numerous, till they form oblique transverse rows of four, five, or six polypes in a row, the outermost being largest. The back of the rod is yellowish, smooth, and free from polypes. The polypiferous part is of a rose-colour. Each polype is 
slender and cylindrical. It has eight tentacula surrounding an oval disc. They are pinnate (the pinnæ about twenty on each side, and crenate) and retractile within a sheath, the margin of which is strengthened by interlacing spicnla, forming triangular, bristling, tooth-like lobes, which alternate with them. The tentacula are pale pink, and formed of a granular tissue. Below the oval circle the body is cylindrical, and marked by eight rose-coloured lines, and at about half its height it dilates into a broad bottle-shaped base, within which are seen the bright red ovaries. The base gradually passes into the investing skin of the rod, of which the sheath of the polype and its teeth may be regarded as an extension.

"When irritated, the Paronaria gives ont a vivid bluish light, which is brightest towards the tip. The light appears to come from the bases of the polypes, and to be connected with the reproductive system."

\section{FaMILY GORGONIADN.}

"Great Occan! strongest of creation's sons, Unconquerable, unreposed, untired, That roll'd the wild, profound, eternal bass In Nature's anthem, and made music such 
As pleased the ear of God! Original,

Unmarr'd, unfaded work of Deity,

From age to age enduring and unchanged,

Majestical, inimitable, vast.

$* \quad * \quad * \quad * \quad * \quad * \quad * \quad *$

Thou bow'dst thy glorious head to none,

Heard'st none, to none did honour but to God,

Thy Maker, only worthy to receive

Thy great obeisance!"-Pollok.

\section{Genus XIX. GORGONIA, Linnaus.}

Gen. Char. Polype-mass rooted, arborescent, consisting of a central axis, barked with a polypiferous crust; the axis horny, continuous and flexible, branched in coequality with the polypemass; the crust, when recent, soft and fleshy, when dried, porous and friable; the orifices of the polype-cells more or less protuberant.-Dr. Jolnston.

1. Gorgonia verrucosa, Sea-fern, or Sea-fan, Cole. (Plate XII. fig. 42.)

Hab. Deep water. Mount's Bay, Cornwall, Mr. Batten; abundant on the south coast, Couch; plentiful, Devonshire, Montague; Exmouth, Rev. T. Hincks. Dr. Fleming states that it was obtained in Scotland by Sowerby.

This has a shrubby appearance, being above a foot in height, and sixteen or seventeen inches in breadth. It has by some been called "Sea-heath." It is fixed to rocks by 
a horny disc; the warty branches expand laterally from near the base. The axis is black, smooth, and glossy, of a compact horny consistence, having a white pith, like that of a rush, in the centre. In a living specimen the external crust is fleshy and flesh-coloured. Crust, when dried, whitish, warty, and friable, with numerous polypecells.

It is thought to be the same as Gorgonia viminalis. It is figured by Ellis (plate xxvii.), and he says, "This was found on the coast of Cornwall. The outside of it is covered over with a crust, full of little lumps like warts, which, when dissolved in vinegar, discover the contracted bodies of polypes with eight claws." The first specimen I ever saw of this was sent to me by a young lady from Devonshire, among some Algæ, to be named. I afterwards got specimens of it from Miss Cutler, when I had the pleasure of visiting her in 1551, in her sweet residence at Budleigh Salterton.

2. Gorgonla pinnata, Professor E. Forles.

Hab. Attached to stones in the Sound of Skye, Mr. M'Audrew and E. Forbes.

"When taken alive it was of a cream-white colour. The polypes are white, with eight dull white granular pinnated 
tentacula: they are very sluggish, and did not expand." (E. Forles.)

3. Gorgonia placomus, Warted Sea-fan, Ellis.

Hab. Coast of Cornwall, Ellis.

"This Sea-fan is of a reddish-brown colour; has its branches disposed in a dichotomous order and a flattish form; they bend irregularly towards one another, but rarely unite. Their mouths are conical, projecting, and surrounded at top by little spines. The bone or support is nearly of the substance of wood." (Ellis.)

Mr. Couch remarks, that Ellis must have been very fortunate in finding this Gorgonia, as neither Mr. Peach nor he had been able to fall in with one among all the Gorgonice that they examined.

4. Gorgonia axceps, Sea-willow, Mr. Dale.

Hab. Deep water, very rare. Near Margate, Mr. Dale ; on the coast of Great Britain and Ireland, Ellis.

Dichotomous, the stem and branches a little compressed. "On both edges of the flat branches are regular rows of little rising cells in the calcareous part, with small holes for an entrance to each." (Ellis.)

"The bone is roundish and small at the ends, of a horny nature, inclining to leather. Specimens recent from the sea 
are of a fine violet-colour, but when we receive them some are yellow, others white." (Ellis.)

Its claims to be British are doubtful.

5. Gorgonia flabellum-Veneris, Venus's Fan.

Hab. Cornwall, Dr. Borlase; Leith shore, Mr. Mackay; Lamlash Bay, D. L.

Though we have mentioned these habitats, we do not believe that it was found, as a British zoophyte, in any of them. When we were in the Isle of Arran it was brought to us as something very rare, that had been dredged in Lamlash Bay. It certainly was a portion of Venus's fan, but a fragment in which life had long been extinct, and cast overboard, we doubt not, from some vessel from foreign shores, that had found shelter in the bay. The high authority of the late Dr. Neill, so worthy a man and so good a naturalist, led many to suppose that it had been found alive at Leith, but a letter from Professor E. Forbes shows, satisfactorily, how a mistake may have arisen. "Dr. Goodsir has a large specimen of the G. flabellum-Teneris, dredged in the Forth. The fisherman who brought it described it as being covered with living flesh when taken. On examination we found that it presented the curious appearance of West Indian incrusting shells and British mixed, and the 
GORGONIA.

living flesh was doubtless a British sponge which had grown round the branches in many parts."

If we must give up this magnificent Gorgonia as British, it is a consolation that it will continue to be more familiar to us than any of acknowledged British growth. It is so strikingly curious and handsome that it attracts the notice of our sailors, who are not in general remarkably prone to admire the works of nature; but this stares them so broadly in the face that they are constrained to observe it, and they often bring it home as a present to their friends, scarcely one of them knowing that it is an animal production, but regarding it is an extraordinary kind of seaweed. Since I began to write this, I have had a very pretty specimen of it brought to me by a little girl, and I had two or three from my kind nautical friends before.

The wisdom of God, as our great British naturalist, Ray, has observed, is shown in the fan-like form which many marine plants and zoophytes are taught to assume. In the present case the safety of the polypidom is promoted, not only by the thin edge being fitted to cleave the waves, but even when the broad side happens to be exposed to the impulse, the waves pass through without doing it much injury, the inosculations of the branches causing it to resemble net- 
work. "That the motion of the water descends to a good depth I prove from those plants that grow deepest in the sea, because they all generally grow flat, in manner of a fan, and not with branches on all sides, like trees, which is so contrived by the Providence of nature, for that the edges of them do in that posture with most ease cut the water flowing to and fro; and should the flat side be objected to the stream, it would soon be turned edge-wise by the force of it, because in that state it doth least resist the motion of the water; whereas, did the branches of the plants grow round, they would be thrown backward and forward every tide. Nay, not only the herbaceous and woody submarine plants, but also the lithophyta themselves affect this manner of growing, as I have observed in various kinds of coral and pori." (Ray.)

In forming their network, the little creatures are taught to give greater strength to the fabric by a few stronger tubes, that proceed lengthways, and a few that irregularly cross the fan. Ellis, in figuring Venus's fan, has chosen a specimen which shows the ingenuity of the polypes in repairing the damage when one of the main stems had been broken through near the base. As the separation of the parts of the great tube was complete, and the upper part of 
the polypidom was attached to the under only by the limber network, which could not long have withstood the tide,since they could not splice the broken main-mast, the little artificers did what was about as well-fitted to answer their purpose. Ellis states, "I have now before me specimens which prove the horny circles which surround and compose the stem and branches to be the work of animals; one particularly, of the Keratophyta, or Sea-fans, called by the celebrated Linnæus Flabellum Veneris, which, by some accident, has had one of the main stems, belonging to the branches, broke quite across. But the broken parts have been kept near to one another by the small reticulated side-branches. The animals, in the progress of their tubes upwards from the trunk, as soon as they met with this obstruction of the broken stem, turned off to one side, and proceeding along the reticulated branches, covered over the vacant spaces with their horny and calcareous matter; after this they made a short turn, to gain the broken end of the upper part of the stem of this branch, and from thence they continued their progress along towards the finer ramifications as usual." "In the same sea-fan," he adds, "there is another remarkable instance of the animals forming the horny part of the branches. This specimen appears to have 
had the progress of its growth stopped by some impending rock or other accident, part of its upper branches appearing as if cut off in a horizontal direction. This, we observe, has diverted the course of the animals back the way they came, so that we find many of the lately-formed cells covered over and confused with an irregular appearance of the calcareous matter. This we can perceive, as far as we can trace the animals back in their retreat; and upon taking off the calcareous matter, we find that the horny substance, which they had deposited since their return, had filled up most of the vacant places in that part of the reticulation."

\section{Genus XX. PRIMNOA, Lamour.}

Gen. Char. Polypidom plant-like, irregularly branched; the axis horny, becoming very hard, continuous; polype-cells protruded far beyond the crust, subpedunculated and moveable, squamous; the aperture furnished with eight smaller testaceous scales.-Johnston.

1. Primino lepadifera, Professor Jameson.

Hab. Coasts of Aberdeenshire and Shetland, Jameson. "The axis, when young, is corneous, but in the older branches it is like bone. The flesh is covered with minute 
fixed scales. The cells are crowded, bell-shaped, and with the aperture, according to Baxter, closed by two valves, covered with imbricated moveable scales. The branches are dichotomous. M. Lamouroux, who first separated this genus from Gorgonia, considers the pendulous cells as the polypes themselves." (Dr. Fleming.)

This zoophyte is very rare in Britain. It is rare even in the Norwegian seas, where the fishermen, on finding it, carry it home, and hang it up as a protective charm against storms. But it must be only young specimens which they thus hang up, for we are told that the fishermen affirm that these marine productions grow to the size of large forest trees. When their nets get entangled on the trunk or stem of the Primnoa, the united strength of several men is unable to free them by eradicating the sea-tree. At times, however, they succeed in pulling up the net by main force, bringing large branches along with it. They think they have good reason to conclude that some of the sea-trees are fifty or sixty feet in height. If there be no mistake, these are sea-trees indeed! 


\section{Fayily ALCYONID ג.}

"The tones of the majestic sea

Have meanings too sublime for me,

When billows lift their voice on high,

And elouds are thundering their reply.

I love to hear its soften'd tones,

Its hush'd complaints, its under moans,

When waves subsiding sink to rest,

And sunbeams slecp upou its breast."-Ellen Roberts.

- Genus XXI. ALCYONIUM, Linncens.

Gen. Char. Polype-mass lobed or incrusting, spongious, the skin coriaceous, marked with stellated pores; interior gelatinous, netted with tubular fibres, and perforated with longitudinal canals, terminating in the polype-cells, which are subcutaneous and scattered. Polypes exsertile.-Jolniston.

1. Alcyonium digitatum, Dead Man's Hands, Dead Man's Toes.

Hab. On stones, shells, etc., in deep water.

This sponge-looking zoophyte takes its name from Alcyon, the kingfisher; and the fable is, that the bird formed its nest of the foam of the sea, and floated it on the deep, and that old Neptune, in kindness, kept the waves in check all the time the bird was hatching;-hence is derived the 
expression alcyon or halcyon days, which we all so much desire.

This is spoken of as being very common on all our shores. It is by no means common on those parts of our shores which are sandy, but we have got very fine specimens from Arran and Cumbraes. When it is large and lobed, it assumes forms to which our fishermen fail not to give appropriate names, such as dead man's hands, dead man's toes, cows' paps. A specimen of the latter kind, found on the shore at Saltcoats, was brought to me as a great wonder. It certainly very much resembled the udder of a little Highland cow. When a specimen is got in a fresh state, the naked eye can easily see that the surface is closely covered with star-like figures, and if placed in sea-water, these starlike impressions project considerably from the surface, showing that they are polypes with eight tentacula. Ellis says that the specimen he figures in plate xxxii. was got at the Nore, adhering to an oyster-shell. "When it first came, I observed the surface full of small papilla, with a star of eight points on the top of each. After it had been suffered to rest for some time in the salt-water, each small star sent forth a polype with eight tentacula." Dr. Jolnnston also remarks, "When a specimen of Alcyonium digitatum is 
placed in a vessel of sea-water, the polypes protrude themselves amazingly, and extend their tentacula, which are thick, obtuse, grooved along the centre, and not longer than the diameter of the disc."

2. Alcyonium glomeratum.

Hab. Dublin Bay, Hassall; Cornwall, Couch.

Though, generally speaking, this Alcyonium is rare, it seems not to be uncommon in Cornwall, so that it is familiar to Mr. Couch. A.fine live specimen of it was brought to us by a fisherman, who had obtained it in his net off Saltcoats, and we have seen another live specimen in the possession of Major Martin, dredged at Cumbraes, and kept for weeks alive in sea-water in a glass vessel. It differs from the preceding one strikingly in colour, which is bright red.

\section{Genus XXII. SARCODICTYON, E. Forbes.}

Gen. Char. Polypidom incrusting, linear, ereeping, anastomosing at intervals, so as to form a sort of network. Polypes distant, in uniserial prominent cells; the tentacula eight, and pinnated.-Johnston.

1. Sarcodictyon catenata.

Hab. Youghall, R. Ball; Lochfine, and in several loca- 
lities in the west of Scotland, Mr. M'Andrew and Prof. E. Forbes; off Cumbraes, D. L.

This we have got several times from a fisherman who dredged it off Cumbraes. It was always on roundish stones about the size of a man's hand, and it wound itself in a meandering manner round the stone, and as the surface was not smooth, it took care to keep in the hollows. It is of a reddish colour. When we first met with it, from its long, small, worm-like appearance, we thought that it was an annelide, till we observed the cells of the polypes, like little warts, dotting it at regular intervals. The polypes are whitish. The fleshy crust contains spicula.

\section{ANTHOZOA HELIANTHOIDA.}

The British species are arranged by Dr. Johnston under the following families and genera :-

Sect. I. Body secreting a calcareous polypidom. Corals.

* Coral cellular throughout. Milleporina.

Cells substellate, with porous interspaces. PocilliPORA. 
** Coral with terminal cells. Ocellina.

Coral free, the base pointed. Turbinolia.

Coral fixed, the base expanded. Caryophyllea.

Sect. II. Bodly coriaceous or fleshy.

* Polypes associated by a common base (gemmiparous). Zoanthina, Elrenberg.

Base root-like, creeping. Zoantrus.

* Polypes separate and single (ovo-viviparous). Actinia, Ehrenberg.

Tentacula in uninterrupted circles. Actiniade.

† Tentacula imperforate.

Body invested in a lobed epidermis. Caprea.

Epidermis normal. Conynactis.

†† Tentacula tubular, retractile.

Base broad, the animal immoveable. Adaysia.

Base broad, the animal locomotive. Actisia.

Base narrow, the animal unfixed. Iluanthos.

$\dagger+\dagger$ Tentacula tubular, not retractile. Aлthea.

Tentacula in tufts, at distant intervals. Lucersiade.

One genus only-Lucernaria. 


\section{MILLEPORINA.}

"Now it is pleasant, on a summer eve, When a broad shore retiring waters leave, Awhile to wait upon the firm fair sand, When all is calm at sea, and still on land, And there the ocean's produce to explore, As floating by, or rolling on the shore, Those living jellies, which the flesh inflame, Fierce as a nettle, and from that its name; Some in huge masses, some that you may bring In the small compass of a lady's ring, Figured by hand Divine. There's not a gem Wrought by man's art can be compared with them; Soft, brilliant, tender, through the wave they glow, And make the moonbeam brighter where they flow."-Crabbe.

\section{Genus XXIII. POCILLIPORA, Lamarck.}

Gen. Char. Polypidom calcareous, tixed, plant-like, branched or lobed; cells scattered over the whole surface, distinct, sunk in little fosses, obscurely stellate, the lamellæ narrow, and almost obsolete.-Johnston.

1. Pocillipora interstincta, Dr.-Hibbert.

Hab. Zetland.

"Cylindrical, with distant immersed stars." (Hibbert.) 


\section{OCELLINA. \\ Genus XXIV. OCULINA.}

\section{Oculina prolifera.}

Hab. Between the islands of Rum and Egg, Dr. Fleming; Shetland, Mr. G. C. Atkinson.

About ten years ago we sent to Dr. Johnston a specimen of coral from Norway, which he returned, named Oculina prolifera, saying that he was glad that it was found in Norway, as it gave hopes that it might be found in Orkney or Shetland. Soon after this I had the pleasure of hearing that a noble specimen of it, weighing six pounds, had been dredged in the Hebrides, and was in the possession of my much-valued friend Professor John Fleming. It occupies an honourable niche in his cabinet. It is worth treasuring up and rejoicing over, and he showed it to me with no small gratification. By that time, however, I had a specimen of my own, though I was constrained to acknowledge that it was not quite equal to his in magnitude. When, in the summer of 1850 , I was on a visit at Mr. Cowan's, Airds House, Appin, I called on Mr. Mr'Millan, at Ardtur, formerly the residence of the late Captain Carmichael, well known as a distinguished naturalist, and, looking round to 
see whether there were any remains of those objects that had long occupied the attention of the former scientific resident, I saw, with surprise and delight, on the mantel-piece a very respectable specimen of my old Norwegian acquaintance, Oculina prolifera. I made particular inquiry as to when and where obtained, and Mr. M'Millan told me that, when his brother occupied a large farm in the island of Barra, he had been in the habit of collecting rare shells for a relative of theirs, a lady of rank in England; that this had been procured at that time, but not being a shell, it had not been forwarded to her. I took good care to give no hint by my tongue how I would like it to be disposed of, and I hope my eye did not proclaim its covetousness. Be that as it may, it was sent to me next day, and I retain it on account of its great rarity, and as a memorial of a remarkably pleasant visit to Appin. It is a good stout coral, fitted to brave the storms of the north-west Hebrides. I may mention that, though I did not become possessor of the Norwegian specimen, I was made welcome to the shells -white mussels as they were called-that were ensconced amongst its branches. There were a few specimens of Terebratula caput-serpentis, then regarded as rare, and one specimen of the very rare Terebratula cranium. 
Mr. Alder mentions that the fine specimen of Oculina prolifera was presented to the Newcastle Natural History Society by Mr. Atkinson; that it is in their Museum, and measures eight or ten inches across.

\section{Genus XXV. TURBINOLIA, Lamarck.}

Gen. Char. Animal like the Actinia, single. Polypidom simple, inversely conical, furrowed on the outside, pointed at the base, and terminated above in a lamellated cup or cell.-Jolinston.

1. Turbinolia borealis.

Hab. Zetland, Dr. Fleming.

"It is inversely conical, pointed, subarcuated, with a concave disc, and a prominent centre; the plates, though defaced, appear to have been equal. It is about five-tenths of an inch in height, and nearly the same in breadth across the star." (Fleming.)

2. Turbixolia Milletiana, Mr. M'Andrew.

Hab. Off Sicily; off the Irish Isles of Arran, Mr. Barlee. This, as represented in Dr. Johnston's plate xxxv., fig. 1, 2,3 , is a beautiful little coral, shaped like a boy's top, with twenty-four longitudiual ribs. It is scareely half an inch in height, and at the top about a quarter of an inch in diameter. Professor Forbes states that it is identical with 
T. Milletiana, found in both the crags. Dr. Johnston remarks, that " this fact assumes great interest as an additional illustration of the permanency of species in general. It is long since the 'coralline crag' was deposited, long enough, methinks, for any good law to develope its effects in its subjects, and yet this very old Turbinolia has not obeyed the 'law of development,' but has steadily maintained, amid the changes around it of very many centuries, its original features, and form, and size, alike careless of human theorems, and insensible to the agency of its innate appetencies and higher aspirations!"

\section{Genus XXVI. CARYOPHYLLEA, Lamarck.}

Gen. Char. Animal like the Actinia. Polypidom permanently fixed, simple, striated externally in a longitudinal direction, the top hollowed into a lamellated stellular cup.-Dr. Johnston.

1. Caryophyllea Suithin, Dr. Fleming.

Hab. Zetland, Dr. Fleming; Devon, Mr. Smith; Cornwall, Mr. Couch; Youghall, Miss Ball; Donegal, R. Ball; Connemara, M'Calla; Oban, Mr. Alder.

The only specimens we have of this interesting little zoophyte are from Miss Cutler, whose researches and discoveries in the south of England are well known. 
The $C$. Smithii is firmly attached to rocks. It is inversely conical, striated or finely grooved externally. It sometimes fastens as a parasite on the stems of seaweeds, and as they are short-lived, full-grown specimens are not found on what is so perishable. It has been found an inch in height, and as much in diameter, but in general it is of much smaller dimensions. Dr. Coldstream, in Dr. Johnston's 'History of British Zoophytes,' gives a very interesting account of observations made on this animal when he was residing at Torquay. When expanded it is very like an Actinia; when shrunk it is almost entirely hid amongst the radiating plates. They are found pendent from rocks; the colours vary - he has seen the soft parts white, yellowish, orange-brown, reddish, and of a fine apple-green. Professor E. Forbes states that the tentacula are in two rows, tinged with orange. "In the dusk the animal gave out a few dull flashes of phosphorescent light."

\section{III. 'ZOANTHINA.}

Character. Animal Actinia-form, gregarious, and compound, arising from a common fleshy or coriaceous base, either root-like and creeping, or crustaccous. 


\section{Genus XXVII. ZOANTHUS, Cuvier.}

Gen. Char. Polypes distant, united by a creeping root-like fleshy band.-Dr. Jolinston.

\section{Zoanthus Couchir, R. Q. Couch.}

Hab. On rocks in deep water, common, Couch.

An excellent description of this may be found at page 73 of the 'Cornish Fauna,' by Mr. R. Q. Couch, who added this zoophyte, as he has done much besides, to the British fauna. This, which is the only European Zoanthus, has by Dr. Johnston been named in honour of Mr. Couch. It is a small species, and composed of a number of $\mathrm{Ac}$ tinice united together at their bases by a thin incrusting fleshy band. It is reddish, and in its contracted state resembles a split pea. When half contracted it assumes a kind of hour-glass form. It is sluggish, and, whether expanded or contracted, continues in the same state for several days.

For the only specimen of it I ever saw I am indebted to the kindness of Mr. Bean, of Scarborough, from whom I have also received many of the finest things my cabinet contains.

When I afterwards got Sarcodictyon catenata dredged in 
this neighbourhood, as the existence of such a zoophyte was then unknown to me, I concluded that it was Zoanthus in a peculiar state.

\section{Famly ACTINIADE.}

"Ah, yes! the sea is still and deep,

All things within its bosom slcep!

The night is calm and cloudless,

And still as still can be,

And the stars come forth to listen

To the musie of the sea ;

They gather-gather-gather,

Until they crowd the sky,

And listen, in breathless silence,

.To the solemn litany." -Longfellow.

Character. Animal single, fleshy, elongate or conical, capable of extending or contracting itself, fixed by its base, but with the power of locomotion; mouth in the middle of the upper disc, very dilatable, surrounded by one or two rows of tentacula ; oviparous and viviparous; marine.-Jolinston.

\section{Genus XXVIII. CAPNEA, E. Forbes.}

Gen. Char. Body cylindric, invested in part by a lobed epidermis, and adhering by a broad base. Tentacula simple, very short, retractile, surrounding the mouth in concentric series.Forbes. 


\section{Capdea sanguinea, E. Forles.}

Hab. Deep water, Isle of Man, Prof. E. Forbes; Falmouth, on a valve of Pecten maximus, W.P. Cocks.

A good description and characteristic figure (fig. 43) of it are given in Dr. Johnston's 'History,' by Professor E. Forbes, who discovered it. When expanded, it is about an inch in height and one-fourth of an inch broad. The colour is vermilion. It is rather an active creature, changing its form often, but always presenting more or less of a tubular shape, like a chimney-crock, or steam-boat funnel. It takes its name from a Greek word signifying a chimney. The shape of the tentacula, which are like the embrasures on the top of a turret, and a brown woolly epidermis, distinguish it from all others of the tribe to which it belongs.

\section{Genus XXIX. CORYNACTES, G. J. Allman.}

Gen. Cliar. Body subcylindrical, but very mutable in figure, adhering by an expanded base; tentacula tubular, with spherical and imperforate capitula, contractile, surrounding the mouth in one or more concentric series.-G. J. Allman.

1. Corynactes viridis, G. J. Allman. 
Hab. Near Cork, Prof. Allman; coast of Cornwall, C. IV. Peach.

A full description of it, by Professor Allman, may be found in Dr. Jolnnston's 'History of British Zoophytes.'

"It is a charming little animal, and by no means rare in the locality where I discorered it (at Crook Haven, in little pools on the shore); the brilliancy of its colours, and the great elegance of its tentacular crown, when fully expanded, render it eminently attractive. Huudreds may often be seen in a single pool, and few sights will be retained with greater pleasure by the naturalist than that presented by these little zoophytes, as they spread abroad their green and rosy crowns amid the algæ aud nullipores and plumy corals, co-tenants of their rocky vases."

Mr. Peach's specimens were yellowish, and their favourite position was to hang from the rock when in the form of the daisy.

\section{Gemus XXX. ADAMSI, E. Forbes.}

Gen. Char. Body expanded, bi-lobed, adhering by a broal base; tentacula subretractile, simple, surrounding the mouth. Forbes. 
1. Adairsia palliata, J. Adams. (Plate XIII. fig. 43, frontispiece.)

Hab. Milford Haven, Mr. Adams ; Torbay and Rothesay, Dr. Coldstream; Stevenston shore, Ayrshire, and Brodick shore, Arran, D. L.; Isle of Man, Prof. Forbes ; Belfast Bay, Mr. W. Thompson and Mr. Hyndman.

Dr. Johnston gives a description of this interesting zoophyte by Mr. Adams, who was the first to discover it. $\mathrm{He}$ gives a still better description by our friend Dr. Coldstream. The general mass of the animal is flattened and extended; the margin minutely crenated; colour of the body reddishbrown, passing into a light cream-colour towards the oral disc; the whole surface striated with white and bluish lines, marked with bright reddish-purple spots. The oral disc is white, bearing on its outer margin numerous short tentacula, arranged in three or four irregular rows. Base fixed to a thin horny expansion attached to the apertures of various dead shells, such as Trochus magus, and forming an extension of the body-whorl of the shell in a spiral form. "The case,"says Dr.C., " thus formed by the old shell and the horny membrane, and covered by the Actinia, I have always found inhabited by a variety of the hermit-crab."- - It seems probable that the horny membrane is produced by the 
Actinia, and that its formation presents a striking instance of the operation of that beautiful law of Nature which makes the habits of one animal subservient to the wants of another." I may insert the following, which Dr. Johnston is pleased to quote at this place from my 'Excursions to the Island of Arran :'- "Many naturalists have observed that there seems to be a treaty of union betwixt the hermit-crab and the spotted sea-anemone. I lately kept one of these pretty creatures for some days in sea-water; it had fastened itself to a little fragment of a screw-shell (Turritella terebra), but its co-tenant in the inside was not a hermit-crab, but a pretty red annelide. Be this as it may, certain it is that on this occasion we found that the spotted anemone had fastened itself to the outer lip of many of the roaring luckies (Buccinum undatum) brought up by the dredge, and whenever there was an anemone without, there we found a hermit-crab within. In all likelihood they in various ways aid each other. The hermit has strong claws, and while he is feasting on the prey he has caught, many spare crumbs may fall to the share of his gentle-looking companion. But soft and gentle-looking though the Actinia be, she has a hundred hands, and woe to the wandering wight who comes within the reach of one of them, for all 
the others are instantly brought to its aid, and the hermit inay soon find that he is more than compensated for the crumbs that fell from his own booty*." Mr. W. Thoinpson states that every shell he saw invested by $A$. maculata was tenanted by Pagurus Prideauxii. This, Dr. Johnston adds, proves the general union, but that Professor E. Forbes assures him that, on the coast of the Isle of Man, the shells to which the Adamsia attaches itself are seldom inhabited by the hermit-crab. He states also that the Adamsia seems to change its habitation according to its size.

The first time I observed the Adamsia was in the island of Arran, before I had turned my attention much to zoophytes. I was in search of shells, wading in the pretty Highland brook called Glenrosa-burn, where it falls into the sea near Brodick. As the tide was in, the water must have been somewhat brackish. I saw numbers of Trochus magus, and to my great surprise the mollusk, as I thought, had mrapped itself round the outside of the shell. The animal was beautifully spotted, and as I did not then know the appearance of the true inhabitant of Trochus magus, I

* 'Excursions to Arran, with reference to the Natural History of the Island,' by D. L. Johnstone and Hunter, Paternoster-row, London, and Princes-street, Edinburgh. 
concluded that the spots of the inside resident corresponded with the external spots of the shell it inhabited. I wondered why there was so general a turn-out, but I ascribed it to the brackish state of the stream.

\section{Genus XXXI. ACTINIA, Linnceus.}

Gen. Char. Body conoid or eylindrical, adhering by a broad base; the space between the mouth and the rim of the upper disc occupied by one or more uninterrupted series of conical undivided tubular tentacula, which are entirely retractile.- $D r$. Jolinston.

Before entering on any description of the various species of these sea-anemones, it may not be improper to make a few preliminary observations on their character in general. They claim attention on account of their beauty; and then we cannot excuse our neglect of them by saying, what is true with respect to not a few of the most interesting objects in nature, that they are too small to be seen without the aid of the microscope, for all Actinia can be seen by the naked eye, and several of them, when fully expanded, are of considerable magnitude. The very names by which they are commonly known, show that their beauty has been both 
seen and appreciated. Even more than a hundred years ago, when little was known of their nature, and when zoophytology was yet in its infancy, before our naturalists had made them an object of study, more common observers had given them appropriate English names. Ellis knew that it would be understood what he meant when he spoke of them as sea-anemones; he says, "their tentacles, being disposed in regular circles, and tinged with a variety of bright, lively colours, very nearly represent the beautiful petals of some of our most elegantly fringed and radiated flowers, such as the carnation, marygold, and anemone." Nay, not only has the resemblance been acknowledged by man, but in one case at least on record, it forced itself on a connoisseur who had more practical acquaintance with flowers than any of our florists or botanists. A distinguished naturalist (Mr. Couch) mentions, that when he was admiring the beauty of a sea-anemone, as on a sunny day it lay with fully expanded tentacula in a shallow rock-pool, a bee, on honey intent, deceived by appearances, pounced upon the marine flower. The tentacula, being at the very surface of the water, instantly caught the unfortunate intermeddler, and in spite of its struggles swallowed it up.

We wish to direct attention to these Helianthoid, or sun- 
flower zoophytes, because they give us a good idea of the beauty and the structure of those coral zoophytes in tropical seas, remarkable for their beauty, and still more for their extraordinary operations. One advantage that we derived from dwelling a little on the way in which the naked green Hydra increased by buds and branches, was, that it led us to know more of the way in which the Sertularice, for instance, increased, though the animal was not seen under its calcareous covering. In the same manner, by the study of our British unclothed sea-anemones we are prepared for forming a good idea of the coral-working zoophytes of foreign seas, many of which greatly resemble our native Actinice, though they can, at will, conceal themselves from our notice by retreating into the beautiful habitations they have formed. Our own Actinice are like Colchicums, or autumnal crocuses, as they are called, which send forth their showy blossoms from the earth, without even a green leaf to protect them; the coral zoophytes are more like a flowering shrub, whose blossoms are defended by branches and leaves, while they have this advantage over the shrub, that they can not only fold their petals, but can retreat for safety into their cells. A French writer, Le Sueur, speaks in rapturous terms of the coral zoophytes of warmer climes: "When the sea is calm, 
it is an admirable spectacle to behold the beautiful velvety (veloutées) colours which they display. They resemble the richest and the most varied carpets; near them are seen Gorgons, Serpulas, whose white, yellow, and red tufts shine with the liveliest splendour, and Amplitrites which raise towards the surface of the water their head crowned with palms rich in the most varied hues. I could not tire myself in admiring the profusion with which these animals are grouped and intermingled; it was with regret, that after having walked long in the midst of them I resolved to tear them from the bosom of the water, and to put fragments of them into a pail (baquet), which I caused immediately to be sent home, that I might examine at leisure the animals peculiar to each of the polypidoms."

This is language that is employed to describe foreign Actinice; but nearly as strong are the terms in which the seaanemones of our own shores are described by one who knew them well, Sir J. G. Dalyell. "Some are distinguished by the beauty of their form, some by symmetrical proportions or by the radiance of their colours. Rows of delicate organs arranged in concentric circles ornament the surface; or deep-waving lobes, bordered with luxuriant fringes, are pendent from the margin. Many are green, or 
red, or yellow, or variegated of diverse vivid hues, equalling the tints of the loveliest roses; hence has the Actinia been distinguished by simple but expressive names-the sea-anemone, the marygold, the animal flower, or by such botanical synonyms as comparison with vegetable efflorescence would justify."

Not less glowing is the description of them which is found in an excellent little book, 'Chapters on the common things of the Sea-side, by Anne Pratt.' " Perhaps the zoophytes best known as such to visitors at the coast, are the beautiful sea-anemones, which offer their loveliness to every eye, and need no microscope to reveal their tints or form. Clustered by thousands on sea-side rocks or sands, adorning the sides of rocky pools with flowers which resemble marygolds or China-asters in their form, but which are brighter in their colours than any flowers which our garden can show; redder than roses, of richer purple than the violet, and wearing the rainbow hues of the gorgeous cactus-flower, which the painter in vain essays to copy, there are few objects in nature more calculated to attract our notice than are these living flowers."

One reason why the beauty of these creatures is not more generally observed, is, that it is manifested only when they 
are covered with water, and even then the passing of a dark cloud over the sun will cause them to fold up their outspread feelers. And yet, though in substance they seem to be as soft and tender as a little mass of jelly, they are not only very tenacious of life, but very capable of conquering and destroying many of their marine neighbours that would be thought more powerful than they. Sir J. G. Dalyell states, "This is a powerful, fearless, and voracious animal. Having chosen a spot for firm adhesion, it spreads abroad its numerous tentacula to the utmost stretch in quest of prey. Nothing can escape their deadly touch. Every animated being that comes in slightest contact, is instantly caught, retained, and mercilessly devoured. Neither strength nor size, nor the resistance of the victim, can daunt the ravenous captor. It will readily grasp an animal which, if endowed with similar strength, advantage, and resolution, could certainly rend its body asunder. It will endeavour to gorge itself with thrice the quantity of food that its most capacious stomach is capable of receiving. Nothing is refused, provided it be of animal substance. It is in the highest degree carnivorous. Thence do all the varieties of the smaller finny tribes, the fiercest of the crustacea, the whole vermicular race, leeches, and the softer tenants among 
the testacea, fall a prey to the Actinia."_- "The remarkable voracity of this creature warns the naturalist to beware of its presence among his collections, otherwise they shall assuredly perish. Simple contact of the tentacula is the prelude of destruction. Some animals, as if conscious of their inevitable fate, seem paralysed by the touch, and yield without a struggle. Others, whose size and strength should ensure indemnity, are held in its relentless grasp; the tentacula crowding faster and faster around, until the victim is speedily swallowed alive." Sir John says, that he has no proof that the Actinia is victorious in consequence of discharging some deleterious fluid on its living prey, as many naturalists have supposed; and he gives it as his opinion, that in many cases it is quite evident that superior power is the only means employed for victory. Dr. Johnston, however, holds a different opinion, founded on observations made by acute naturalists. "To disable the animal and render its struggles for escape unavailing, the class is furnished with poison-vesicles and spicula, similar to those which have been described as existing in the tentacula of the Hydra." These organs were first discovered, I belicve, by M. Quatrefages, but they have been described also by $\Pi$ agner and Erdl. They are little elliptical capsules 
furnished with a projecting spiculum, situated under the skin, sometimes scattered over the whole body, and in other species confined apparently to the tentacula or even their tips. The poison secreted by them is very variable in its power, and this, it is probable, is owing to the different states of the animal at different seasons. From one of the Ray Society publications, we learn that Erdl has ascertained that the stinging organs of Actinia are much more active in spring, which is the breeding season. Dr. Johnston says, that he has handled our commoner. Actinia without experiencing more than a slight heat in the fingers, scarcely sufficient to draw attention, but in Anthea he states that the activity of the poison is greater. From my own experience, I can say nothing as to this stinging power; for though I have handled not only the commoner Actinia, but also the larger and less common Anthea, I never felt anything approaching to stinging; but I never touched a tentaculum without perceiving the tip of it had some prehensile property, by which it took a slight hold of the skin of the finger, causing a kind of rasping feeling when withdrawn. It may be, however, that the fangs lad not fair play with my fingers, if somelow or other they are sting-proof. Quoting again from Mrs. Anne Pratt's interesting 'Sea-side Chapters;' 
"It appears that different persons are variously affected even by touching the same Actinia. The author had placed in a vessel of sea-water a fine specimen of the fig marygold sea-anemone, which she was accustomed to touch many times during the day. The tentacula closed immediately around the intruding finger, producing only a slight tingling. Her surprise was great at finding that the same anemone, on being touched by another person, communicated a more powerful sensation, which her friend assured her was felt up the whole of the arm. More than twenty persons touched this anemone, and the writer was amused by observing how variously they were affected; some being only slightly tingled, while others started back as if stung by a nettle."

The locomotive powers of the Actinice are not great. In the course of a few hours I have observed that they had removed some inches from their former position. Their tardy progression is effected by extending in advance orte edge of the base, and drawing the opposite edge slowly after it. Its senses seem obtuse. Its most favourite food may be within a hair's breadth, but it makes no attempt to seize it unless it come into actual contact. Though the tentacula are so capable of extension, there is no spontancous elongation, unless they accidentally touch the prey. More singular 
still, should the vessel be gradually emptied, or the water evaporate so as to leave the animals totally or partially dry, they never lower the base for immersion in the residuenot even when the tentacula can reach its surface. They are very long-lived, Sir J. G. Dalyell having kept them in jars ten, twelve, and twenty years. It is not a small injury that deprives them of life, for, like the Hydra, they have the power of renewing mutilated parts, and of increasing in number by being cut in pieces; but the worthy old baronet, from whom we have so often drawn information, very properly adds, "the cruel experiments proving these properties are most reprehensible."

Well is it for our marine marygolds, anemones, and China-asters, that our British gourmands have not learned to think them as grateful to the palate as they are pleasant to the eye. The Italian epicures boil many kinds of Actinice in sea-water. They have a shivering texture when thus prepared, somewhat like calf's-foot jelly ; their smell is somewhat like that of a warm crab or lobster; and when eaten with sauce, they form, to their taste, a savoury repast. As long as we can get a good herring or haddock out of the sea, we shall allow, I suspect, the most tempting of our Actinia to bloom unscathed in all their beauty. 
"Meantime, with fuller reach, and stronger swell,

Wave after wave advanced;

Each following billow lifted the last foam

That trembled on the sand with rainbow hues;

The living flower that rooted to the rock,

Late from the thinner element,

Shrunk down within its purple stem to sleep,

Now feels the water, and again

Awakening, blossoms out

All its green anther-neck."-Southey.

† Shin smooth.

1. Actinia Mesembryanthemum. (Plate XIII. fig. 45, frontispiece.)

Hab. On rocks, between tide-marks. Common.

This is to be met with on all our shores, abounding often in rock-pools. The older French writers call it "la plus petite des orties de mer," and yet it is not a very small seanettle, being about an inch and a half in diameter. It has something, we have seen, of the stinging power. It is of a liver-colour; the base is generally greenish, with an azure line. Around the margin of the mouth, there is a circle of twenty-five azure-blue tubercles, like so many turquoise beads. On each side of the mouth there is a small purple spot, "and the moutl itself is encircled with a fringe of numerous very short tentacula, of a pale or roseate colour, 
which is rarely exposed, and has been hitherto unnoticed." (Dr. Johnston.)

2. Actinia margaritifera, J. Templeton.

Hab. Copeland Isle, Templeton; Donegal Bay, E. Forbes. This is described by Professor E. Forbes as a very distinct species. The integument is much tougher than that of the former, having a leathery feel. The colour is a dull olive-green; the tubercles of the most vivid ultramarine.

3. Actinia chiolocca, $W$. P. Cocks.

Hab. In various places on the Cornish coast, W.P. Cocks. Many of these Actiniæ, which have been seen only by Mr. Cocks, or some other fortunate discoverer, we shall notice very briefly, however beautiful many of them must be. The short description given of this by Mr. Cocks, tells us of the loveliness of its appearance; "colour bright scarlet, tentacula lighter and brighter than the body; edge of disc studded with white tubercles; a light flesh-coloured stripe encircling the edge of the base."

4. Actinia chrysosplenium, $W$. P. Cocks.

Hab. Attached to stones at low-water mark, at St. Ives, W. P. Cocks.

Again I give from Dr. Johnston part of the description by Mr. Cocks. "They vary in colour from a bright pea- 
green to the darker holly-leaf tint, striped or dotted with bright yellow; the labial tubercles and edging of the base of the same colour, only somewhat lighter in tint. It is a small species."

5. Actinia coccinea.

Hab. On rocks and searreeds; coast of Ireland, E. Forbes.

"Varied with white and red; tentacula cylindrical and annulate." Dr. Johnston states, that he formerly considered this as the young of $A$.crassicomis, but that he gives it now as distinct, on the authority of Professor E. Forbes.

6. Actinia viduata, $W$. Thompson.

Hab. Between tide-marks; Lahinch, county of Clare, Prof. E. Forbes and Mr. W. Thompson.

"Grey, with longitudinal white streaks; the tentacula white, with a dusky streak along each side." ( $I V$.Thompson.)

7. Actinia Troglodites, Dr. Jolinston.

Hab. On rocks between tile-marks; Berwick Bay, Dr. Johnston; Cornwall, Mr. Couch; Isle of Man, Prof. E. Forbes; Moray Firth, Mr. A. Robertson.

This Actinia is more generally distributed on our shores than some of the preceding. It might be mistaken for a small variety of Actinia Mesembryanthemum, but on exami- 
nation it is found to be distinct. It is only about half a inch in diameter, and rather less in height. It is olive-green, with snow-white stripes. The tentacula are numerous. Dr. Johnston gives the following interesting account of it: "This small but exceedingly pretty species has often interested us in observing its habits. It occupies a hole fitted to the size of its body, in our shelving, soft, slaty rocks, where, when covered with water, it expands into a wide circle, its oral disc and tentacula raising them scarcely above the level of its habitation. Thus the Actinia retains itself unbosomed, as if proud to display the beauty that its Author has given it; but should, perchance, a rude hand or foe touch or ruffle the tentacula, then doth the creature instantly shrink and withdraw within itself and its furrow, until it has become nearly undistinguishable. The deserted holes bored by the Pholas is a favourite retreat for this Actinia, hence the specific name Troglodytes," suggested by Mr. Price, in reference to the little classical people of that name, said to live in dens and caves near the Arabian Gulf. 8. Actinia alba, Cocks.

Hab. Coast of Cornwall, in the crevices of rocks, IT. P. Jocks.

This is minute, half an inch in diameter when expanded; 
when contracted it is like a little rough wart. Its colour white; it has four rows of tentacula; lips bright yellow. (IV. P. Cocks.)

9. Actinia anguicoma, J. Price.

Hab. In the Menai Straits, near Bangor, J. Price.

This, as described by Mr.Price in Dr. Johnston's 'History,' and figured, reminds me much of an Activia which I once saw at Lamlash, in the island of Arran. I was much struck with the length of the creature, when compared with its breadth; but as I was just leaving the island, I had not time to become acquainted with its history, and though imbedded in sand, the sand was mixed with stones, closely jammed together, so that I could not get it out to carry it along with me. Mr. Price gives a full description, from which I shall extract only a little. "Diameter of the base is an inch; the height from half an inch to five and a half inches. Presents by turns the two extremes of the greatest cylindrical length I have ever seen in any Actinia, and the most abject flatness. The former state is constant at night, and may be induced by artificial darkness in an hour or two." Dr. Johnston's figure (48) reminds one of a cylindrical monumental pillar surmounted by an abundant collection of serpents: these snake-like tentacula are about fifty in number. 
10. Actinia intestinalis, Dr. Fleming.

Hab. Adheres to rocks at low-water mark; Zetland, Dr. Fleming.

This bears some resemblance to the former in its comparative length and breadth, but in many respects it is very different. "When contracted," Dr. Fleming says, "the body seems like two broad rings of nearly equal breadth, and about half an inch in diameter; when expanded to nearly two inches, the body consists of two cylindrical portions of different dimensions, smooth, pellucid, yellowish." In Dr. Johnston's figure (49), in its contracted state it is like two joints from the Giant's Causeway laid one above another; in its expanded state, it is like a telescope when drawn out.

11. Actinia Chrysanthellum, $C . W$. Peach.

Hab. Coast of Cornwall, Peach.

This is one of Mr. Peach's numerous discoveries. It is almost white, with six broad stripes and three narrower ones betwixt each of the two broader ones, running the whole length of the body, and crossed by narrow transverse ones. The tentacula are twelve. Though found among stones in the sand, it does not attach itself to the stones, but lies buried in the sand with the head above. 


\section{Actinia biserialis, Forbes.}

Hab. Frequent among rocks at low-water in the island of Herne (Guernsey), Prof. Forbes.

Professor Forbes describes it as appearing pedunculated from the narrowness of the lower part of the body ; tentacula in two rows, the inner row of sixteen, three times as long as those of the outer row; colour dark brown, with blue stripes bifurcating towards the base.

13. Actinia vermicularis, E. Forbes.

Hab. On shells; dredged by Prof. E. Forbes, and Mr. M'Andrew, in deep water in Zetland.

This is, in Dr. Johnston's 'History,' described by Professor Edward Forbes as cylindrical, long, smooth, greyishpink; disc white, with twenty-four long tentacula, and a few short ones outside. When contracted and not attached, more like a Planarian worm than an Actinia. When irritated, gives out in the dark a vivid phosphorescent light.

†† Skin with porous warts.

14. Actinia gemmacea, Gartner.

Hab. Coast of Cornwall, Gærtner.

It is thus described by Ellis:- "The colour of the stem is of a pale red near the base; the rest of a yellow mixed with grey ash-colour. The glands of the middle row are 
white, the rest of the same colour as the stem. 'The feelers are of a whitish colour, varied at the upper part with several cross lines and brown spots of an irregular figure, like the backs of some snakes." The warts with which the Actinice of this section are marked, are all perforated, so that water contained in the body is often ejected through them. They form also, according to Mr. Cocks, the points of adhesion for all the stones, shell, and sand which cover the body, and are therefore suctorial.

15. Actinia monile, J. Templeton.

Hab. Belfast Lough, rare; Templeton.

Body cylindrical, greenish, marked with about sixteen lines of bead-like tubercles; when contracted, scarcely larger than a pea.

16. Actinia coriacea.

Hab. Between tide-marks, buried in crevices of rocks, and in sand, common.

It is about two inches in diameter at the base, variously coloured, often reddish, blotched with green, covered with many pale perforated warts : the tentacula are numerous, in three or four series. It attaches itself to sand-covered rocks, and is often pretty much buried in the sand, so as to be partly concealed when in a contracted state. Its warts 
stand it in good stead, for they have the power of causing to adhere to them sand and gravel, and fragments of shells, so that the body is quite covered. This, it is probable, answers a double purpose. By this covering, the animal, when left by the tide naked, is defended from the scorching beams of the sun; it answers nobly also the purpose of concealment. That kind Providence which cares for the inferior animals, furnishes various means of eluding their enemies. The ptarmigan, which inhabits the lofty mountains, gets white plumage when winter returns, so that even the keen-eyed eagle can scarcely distinguish it from the snowclad peaks among which it dwells. Were the alpine hare to be white in summer, it would be too conspicuous when skipping along the heath; and it would be not less so in winter, when all is white around, were its fur not to lose its summer hue, and to become white as the mountain snow. Nothing could be better fitted to conceal this Actinia, which abounds on our shores, than this very covering with which it knows so well how to clothe itself. When the ebbing tide leaves the sand-covered rocks dry, a sea-anemone of so large size, even when contracted, would be very observable. But when its tentacula are all retracted, and the warty skin covered with the sand and shelly fragments that so firmly 



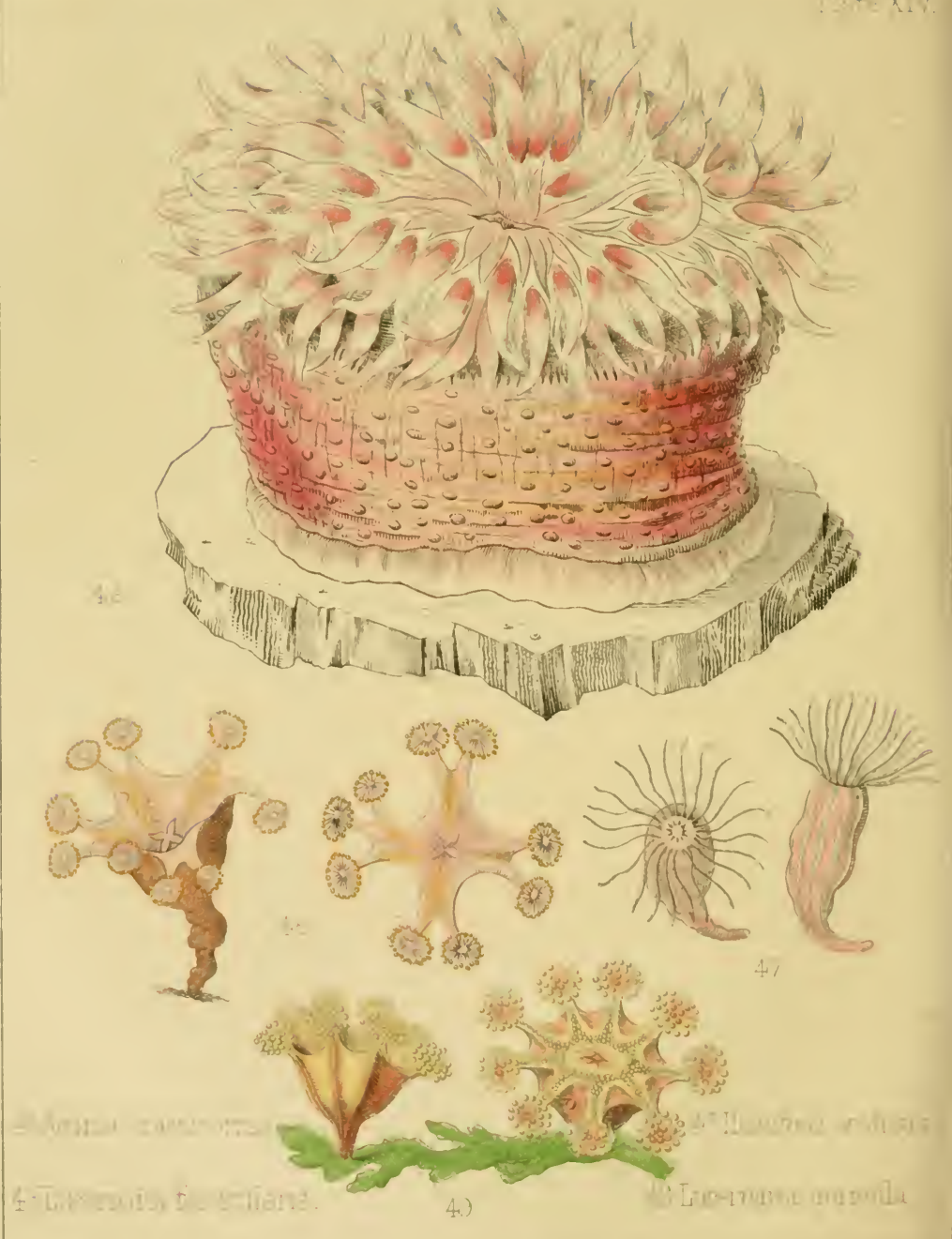


adhere to it, it is so like everything around, that it is very difficult to detect it,- - so much so, that very often I have not had the slightest suspicion of an Actinia being at hand, till by some accidental pressure the water squirted up through its warts and tentacles. When the tide returns, however, the anemone unfolds itself in beauty, and a marine flower is immediately seen where there was nothing but sterility before. The tentacula are shorter than the body, and are annulated or variegated with white or red.

17. Actinia crassicornis. (Plate XIV. fig. 46.)

Hab. On old shells and stones from deep water.

This is a fine species, and one of the largest of our Actinice. It is larger than the last, less leathery, and more vividly coloured. Mr. Cocks says, that the most distinctive character is the readiness with which the rim of the peristomatious disc can be thrown into undulations, or twisted awry; to which Dr. Johnston adds, the ease with which the body is filled with water until it becomes bladdery and diaphanous. He states, besides, that it never indues itself with an extraneous covering, like the preceding. It is about four inches in height, and fully more when expanded betwixt the tips of the opposite tentacula. Its beauty will be very evident when we quote part of the description by Sir J. G. Dalyell 
and Dr. Johnston. The former says, "No species is equally diversified in colour and aspect. Red is usually predominant. The surface of many, however, is variegated red and white, like a rose; or with orange-green and yellow intermixed. One occurred almost totally white, another wholly primrose-yellow. It may be truly affirmed that the diversities baffle enumeration and description." Dr. Johmston remarks, "It is very sportive in its colours, and some of the varieties are eminently beautiful. One is of a bright scarlet, studded over with pale warts like ornamental beads; another is of a cream-colour without spot or stain; another is of a pale sulphur-yellow, or greenish with orange-coloured stripes, the oral disc and vesicular lobes borrowing the hues of the wild rose." In the south of England, according to Mr. Cocks, it is occasionally a littoral species, being found in the crevices of sheltered rocks. It is not so in the west of Scotland, where the only specimens I have seen were brought by fishermen from deep water. Major Martin, at Ardrossan, has at different times kept for weeks fine specimens from deep water off Cumbraes, and they quite answered the descriptions given as to size and diversity of beautiful colouring. In Italy and the south of France, "ils la lavent fort et souvent, puis la fricassent légèrement en 
la poêle, et après cela ils la mangent avec beaucoup de plaisir."

18. Activia Parasitica, $R$. Q. Couch.

Hab. Coast of Cornwall, on the claws of a crab, Mr. Couch; on Pecten maximus and Buccinum undatum, W. P. Cocks.

The body of the animal, when expanded, columnar; skin coriaceous, sprinkled with little warts.

19. Actinia Bellis, Gartner.

Hab. Cornwall; island of Rathlen, Templeton; Ballyhone Bay, county Down, W. Thompson; island of Arran, D. L. ; Dalkey Island, Hassall.

"The disc is formed like a star, which, according to the figure that is traced out by the innermost row of the feelers, consists of many angles. The colour of this part of the body is a beautiful mixture of brown, yellow, ash-colour, and white, which, together, form variegated rays, that from the centre or the mouth of the animal are spread over the whole surface of the disc." (Gartner.) It is a littoral species, and generally found in pure water, yet Mr. Cocks states, "he visited a part of the shore which was composed of mud, sand, and decomposed algx; many of the stones, when lifted, presented a face as black as the skin of an 
African, and sent forth a rich aroma of sulphuretted hydrogen. It is thickly studded with stones, varying in size and weight from two ounces to thirty pounds. 'There are a few remnants of stunted rocks, thinly scattered, from four to eight inches high : these are covered with Fucus vesiculosus and serratus. In turning the stones over, I was astonished to find in this Pandorian locality herds of the Actinia Bellis, in prime condition, jackets as red as a Kentish cherry, tubercles on external portion of the disc light neutral tint, and strongly marked, so pugnacious, that when touched water issued in full streams from nearly all the ducts. The ground was literally covered with them."

20. Actinia Dianthus, Ellis, or A. plumos.i, Dalyell. Sea Carnation. (Plate XIII. fig. 44, fiontispiece.)

Hab. On rocks and shells in deep water.

"Body cylindraceous, smooth; oral disc marked in the centre with clavate radiating bands; tentacula numerous, irregular, the outer small, and forming round the margin at thick filamentous fringe." (Ellis.)

This is well deserving of the compliment paid it by Müller, when he speaks of it as "Actiniarum pulcherrima," the loveliest of the sea-anemones. When contracted, the cylindrical body is about three inches long, by one and a half in 
diameter, but when expanded it is five inches in height and four in diameter. Sir J. G. Dalyell says that a good specimen, expanded, is six inches in height and five in diameter. He prefers the name $A$. plumosa, which certainly is very descriptive, and remarks, "Of all the Actinice inhabiting the Scottish seas, this species is probably the largest, and certainly it is the most beautiful." The tentacula are very numerous, and form a dense fringe of singular beauty. To be convinced that it is more than entitled to all that is said of its elegance and beauty, a person has only to look at the splendid figure given of it by Sir J. G. Dalyell, in plate xlix. Dr. Johnston states that it is of a uniform white, olive, cream, or flesh colour. Sir J. G. Dalyell says, "Remarkable diversity of colour is incident to it. It occurs of snowy white, of peach-blossom, lemon-yellow, orpiment-orange, and the like; but it is equally beautiful under every hue." In Sir John's magnificent figure already referred to, the body is reddish-brown, the mouth orange, the disc lilac, and the gorgeous plumes a mixture of yellow and white. We have repeatedly found it in the west of Scotland, but the specimens were always milk-white. The first time I saw it was at Millport, in the island of Cumbrae. Observing, from the deck of a steamer, three or 
four large specimens which were projecting from the wall of the pier, on which they had fastened four or five feet under water, I was much struck with the graceful scolloped appearance which the fringe had assumed, and I could not imagine what they were. I had to rest satisfied, however, with a distant view, as the water was too deep, and my time too short, for attempting to reach them. The next time I fell in with it was in a cleft of a rock in a small islet off Saltcoats. The full-grown specimens have the power of altering the number of the lobes forming the plumose margin of the disc. In young specimens the fringe does not become lobed.

Most opportunely, just as I was closing this description, Major Martin told me that he had got a magnificent Actinia from the island of Arran; and when I saw it in a gold-fish vase, which it almost tilled, I was delighted to find that it was the finest specimen of the Actinia plumosa, or the sea-carnation, I had ever seen. It is now in my possession, and my daughter Isabella is at present employed in making a drawing of it, which, with the Major's helping hand, will form, I trust, a beautiful frontispicce for my book.

In some respects it differs from any I have seen alive, and it is different, also, from the one of which there is such 
a noble figure in the second volume of Sir John Graham Dalyell's splendid work. The stem of his is brownish, and the disc and plumes are lilac and light yellow. This one is a fine lively salmon-colour, though lighter or darker in different parts, according to their position and expansion. The mouth is orange; the disc light salmon-colour, and the plumes or fringes are of the same colour, but still lighter, towards the edges, like a fleecy silvery cloud, with a slight tint of yellow. The body, when expanded, is marked with numerous longitudinal veins of a lighter shade, sometimes straight and occasionally wavy. These are crossed by annulations of a yellower hue at the distance of about half an inch from each other, the intermediate space being marked with very faint veins running parallel with the rings. These are scarcely perceptible; but the longitudinal veins, crossed by the ochre-tinted rings, show about enough of tartan to mark its Highland origin. When it is about to fasten itself on the bottom of the vessel, it spreads forth thin scolloped folds around the base, longitudinally veined; but these are hid when adhesion has taken place.

The upper portion of the external covering is very like the monophyllous calyx of a flower. From this sheath, when it expands, the plumes come forth like an unfolding 
blossom; and in this they are completely wrapped up when it again contracts its gorgeous corolla.

It is about six inches in height, and the dise about five inches in breadth. The stem is about two inches and a half in diameter.

\section{Genus XXXII. ANTHEA, Dr. Johnston.}

Gen. Char. Body cylindraceous, adhering by a broad base; tentacula disposed in circles round the mouth, elongated, tapered, and incapable of being retracted within the body.-Johnston .

1. Anthea cereus, Gartner.

Hab. Cornwall, Gærtner; Anglesey, Pennant; Torquay, Dr. Coldstream; Isle of Wight, W. Thompson; Dublin Bay, A. H. Hassall, R. Ball, E. Forbes, G. C. Hyndman; Clew Bay, West of Ireland, W. Thompson; Cornwall, Mr. Couch and Mr. Peach.

It is described by Gærtner as of a light chestnut-colour, sulcated lengthways; the feelers, in one of full size, about two hundred; they are longer than the body, of a beautiful sea-green colour, except the tops, which are of a lively rosered; the dise is of the same colour as the body. Mr. Couch says it is very active, sliding along on its base, or by turning on its oval face, and moving more rapidly by means of 
its tentacula. The tentacula are constantly expanded and in motion.

2. Anthea Tuediæ, Dr. Johnston.

Hab. Coast of Berwickshire, in deep water, rather rare, Dr. Johnston; Gourock, Mr. Caw ; off the islands of Cumbrae and Arran, D. L.

This is of large size, measuring, even when contracted, three inches in length, and nearly as much in diameter; and when expanded it is more than four inches in diameter. There are several rows of tentacula; those of the innermost row being the largest, and nearly two inches in length. It cannot retract its tentacula. As it is of a uniform fleshcolour, it has nothing attractive when seen out of the water, for it is very like a lump of raw flesh. It improves in appearance when placed in the water and fully expanded. My first acquaintance with this species was through Mr. Caw, who got a specimen of it at Gourock, and kept it in seawater for several years. As winter approached it became contracted, and lay motionless in the bottom of the vessel till spring, when it blew itself up to its former dimensions.

I have had several specimens of it sent to me from Cumbraes, where it is often got by fishermen on their long lines. I kept one of them for more than a month in a vessel, in 
which it swelled to a great size. It was voracious, and swallowed, greedily, periwinkles and bits of haddock and whiting. By mistake, some person gare it a small piece of a salted fish, which it swallowed, but soon rejected. During the short time that it retained it, it had injured its stomach, for it continued to twist itself very much, turning out the lobes of its stomach, but finding no relief. In a short time the stomach was completely turned out, and soon after the poor animal died.

\section{Genus XXXIII. ILUANTHOS, Forbes.}

Gen. Char. Body cylindrical, tapering to a point at its posterior extremity, free? Tentacula simple, retractile, surrounding the mouth.-Forbes.

1. Iluavthos Scoticus, E. Forbes. (Pl. XIV. fig. 47.) Hab. Lochryan, E. Forbes; Balbriggan, Ireland, Mrs. Hancock.

It is described by Professor Forbes as a free Actinia, about an inch and a balf in length, the body large above, but tapering towards its posterior extremity; the mouth surrounded by a numerous circle of tentacula. The body is of a pink colour, with white longitudinal stripes; the 
tentacula are greenish. It is thought that it fixes itself in the mud by means of the attenuated extremity; hence it was named Iluanthos-mud-flower. The only specimens I have seen of this rare creature were in the possession of Major Martin, of Ardrossan, who had procured them from Cumbraes, where they had been brought up from the deep by the fishermen's long lines.

\section{FAMILY LUCERNIAD里.}

"God visible, invisible who raignes, Soule of all soules, whose light each light directs, All first did freely make, and still maintains; The greatest rules, the meanest not neglects; Fore-knowes the end of all that He ordaines; His will each cause, each cause breeds fit effects ; Who did make all, all thus could only leade, None could make all, but who was never made." Alexander, Earl of Stirling. 1600.

\section{Genus XXXIV. LUCERNARIA, Müller.}

Gen. Char. Body narrow towards the adhering extremity, expanding into an oval disc, which is divided into lobes bearing tentacula.-Dr. Fleming.

1. Lucernaria fascicularis, Dr. J. Fleming. (Plate XIV. fig. 48.) 
Hab. Common in Zetland, on the broad leaves of Fuci, Dr. Fleming; Donaghadee, Templeton; Hellswick Vöe, Zetland, dredged by Prof. E. Forbes and Mr. M'Andrew; Ardrossan, Mr. Joshua Alder; Saltcoats, D. L., jun.

It is found that this is synonymous with Inecrnaria quartrangularis. "The peduncle of the body is produced; tufts of tentacula in pairs, about a hundred in each." 'The body is bell-shaped, quadrangular, concave: it generally hangs downwards. The colour is dark brown, though, from what Templeton says, it may have other hues. "When at rest," he says, "it assumes very much the form of a common drinking-glass, and is exceedingly conspicuous from its beautiful rose-tint." Our Ayrshire specimens are so far from being conspicuous, that we never observed it till it was detected by the more practised eye of Mr. Alder, when residing at $\Lambda$ rdrossan for a short time; and we afterwards found it when we knew its appearance. It gives out, in the dark, when irritated, bright flashes of bluish phosphorescent light.

2. Lucerraria auricula, Montagu. "(Plate MIV. fig. 49.)

Hab. Coast of Devonshire, Montagu; on Fuci, near low-water, on different parts of the coast, Dr. Fleming. 
This is a very beautiful creature, sometimes pink, and in other cases brown, purple, or yellow. It adheres by a short stalk, and spreads itself out into a kind of bell-shaped blossom, the margin of which is set round with eight short arms, each of these terminated with a round tuft of about sixty filaments, bearing rounded glands.

3. Lucernaria campanulata, Dr. John Coldstream.

Hab. On seaweeds, near low-water mark, Torbay, Dr. Coldstream; Berwick Bay, Dr. Jolınston.

About an inch in height, of a uniform liver-brown colour. The interior is hollowed like the blossom of a flower. Dr. Coldstream, who kept a specimen for some weeks in seawater, says that it is a hardy animal, constantly expanded, except when very roughly used.

The Lucernaria, in general, can swim with some rapidity in the water, by alternately expanding and contracting the body. When in a state of expansion, Dr. Johnston remarks, few marine worms exceed them in beauty and singularity of form; when contracted, they are shapeless and easily overlooked. He gives a quotation from Lamouroux respecting this Lucernaria, which I shall take the liberty of translating. "I took the precaution of changing, twice a day, the water in which my Lucernaria were kept. One of 
them, in a vase by itself, performed movements which appeared to me extraordinary in a creature of so soft a consistence, after I had given it a fresh supply of water. With a lens, I perceived that these movements were caused by the presence of an animalcule, which the Lncernaria seemed to pursue, turning to the right and to the left, endeavouring to catch it. Every time that it removed to the distance of about an inch, the Lucernaria ceased to move; if it drew nearer, the chase forthwith recommenced, and the movements were quick and lively. The animalcule was at last caught by the tentacula of one of the rays, which immediately bent back towards the mouth; the other rays continued always expanded: this ray resumed, by degrees, its ordinary position. Having procured other animalcules, I gave them to my Lucernaria, and I had the pleasure of seeing the same movements repeated."

4. Lucernaria cyathiformis, Sars.

Hab. Southeud, Arran, D. L., jun.; Corrigils, Arran, D. L.

So far as I have known, this Lncernaria has not bcen observed anywhere in Britain except in the island of Arran. $\mathrm{A}$ few years ago it was got in great abundance on rocks in the sea at Southend, isle of Arran, and as Mr. Alder was 
then residing at Lamlash, it was shown to him, who kindly took a drawing of it and sent it to Dr. Johnston, who has given it a place in his ' History,' as fig. 86, p. 476. Soon after, Mr. Alder discovered that it had been figured and described by Sars, in his 'Fauna of Norway,' as Lncemaria cyathiformis. Its form greatly resembles some of our old silver communion-cups, with a fringe round its mouth. In its structure and substance it is like the other Incernarice. "The tentacles are arranged in eight tufts round the interior of the disc; and they are extended beyond it, when the animal is alive." It would appear that it is not very rare in the island of Arran, for I got it afterwards on the east side of the island, in a rock-pool at Corrigils.

\section{Class II. POLYZOA.}

The Polyzoa are divisible into two orders :-

I. Infundibulata. Natives of the sea. Polypes compound; the mouth surrounded with ciliated filiform retractile tentacula, which form an uninterrupted circle: ova ciliated. 
II. Hypocrepia. Lacustrine or fresh-water. Polypes compound; the mouth surrounded with ciliated retractile tentacula, interrupted or depressed on one side, so as to assume a crescentic or horse-shoe form: ora unciliated.-Dr. Johnston.

\section{POLYZOA INEUNDIBULATA.}

The families and genera are thus arranged:-

* Polypidoms calcareous; the cells tubular, with a round terminal aperture, uncorered with an operculum. TuBULIPORINA.

Family I. Polypidoms multiform, massive or crustacenus. Tubuliporide.

Polypidom wart-like, with a defined base; the cells sub-erect, aggregated, or imperfectly rowed. TuBULIPORA.

Polypidom crustaceous, undefined; the cells horizontal, semi-alternate. Diastopora.

Polypidom erect, branched; the cells opening all round, semi-altermate or irregular. Pustulipora.

Polypidom dichotomous; the segments free; cells in alternating cross-rows on one surface. IDHoxis. 
Polypidom creeping, adherent and ramous; the cells in one or more series. ALECTO.

Family II. Polypidoms confervoid, jointed. Crisiade.

Polype-cells uniserial. " Crisidia.

Polype-cells biserial. Crisia.

** Polypidoms calcareous or membrano-calcareous, multiform, composed of oblong or oviform cells, whose subterminal aperture is closed by a membranous fold or operculum. Celliporina.

Family III. Polypidoms branched in a confervoid manner; cells oblong; no ovarian capsules. EucraTIADE.

† The polypidom erect.

Cells produced in a single linear series. Eucratea.

Cells geminate. Gemellaria.

†† The polypidoms creeping, adnate.

Cells linked, anastomosing. Ніртотнол.

Cells scattered, erect. Anguivaria.

Family IV. Polypidoms massive`or crustaceous, composed of ovate cells in juxtaposition; the aperture often furnished with a globular capsule. CelLrPORIDE.

Polypidom lobed or ramous; cells heaped. Cellipora. 
Polypidom crustaceous; cells in a single layer. Lepralia.

Polypidom crustaceous; cells quincuncial. MemBRANIPORA.

Family V. Polypidoms multiform, composed of oblong sub-quadrangular cells, disposed in semi-alternating series; the cells conjunct, horizontal to the plane of axis, with a subterminal or lateral aperture, usually covered with an ovarian capsule. EsciIARIDE.

Polypidom foliaceous or membranous, composed of several series of oblong sub-quadrangular cells, on two planes, or one only. Flustra.

Polypidom membrano-calcareous, frondescent; the cells immersed, in a double layer placed back to back, like the cells in honey-comb. Eschara.

Polypidom calcareous, frondescent, netted; the cells on the upper side only. Reterora.

Polypidom dichotomous, with jointed cylindrical branches; cells immersed, rhomboid. S.luicornia. *** Polypidoms sponge-like, fleshy, polymorphous; the cells irregular in disposition, immersed, with a contractile aperture; no external ovarian capsules. HALcronelles, Ehrenh. Corall. 153. 
**** Polypidoms confervoid, horny, fistular; the polypecells free. Vesicularina.

Family VI. Body of the polype separate from the parietes of the cell, which is deciduous. VesicuLARIAD无.

Polype-cells uniserial, coalescent. Serrolaria.

Polype-cells uniserial, disjunct. Vesicularia.

Polype-cells scattered, solitary. Bearia.

Polype-cells clustered, irregular; the polypes with eight tentacula. VaLKeria.

Polype-cells clustered, irregular; the polypes with ten tentacula. Bowerbankia.

Polype-cells clustered, irregular; the polypes with twelve tentacula. FareLLA.

Family VII. Body of the polype adnate to the cell. Pedicelline.

Only one genus-Pedicelitisa.

"Here, too, were living flowers,

Which, like a bud comparted, Their purple cells contracted;

And now in open blossom spread,

Stretched like green anthers many a seeking head; 
And arborets of jointed stone were there, And plants of fibres fine as silkworms' thread, Yea, beautiful as mermaids' golden hair

Upon the waves dispread."-Southey.

\section{Tribe 1. TUBULIPORINA. \\ FAMily TUBULIPORIDA.}

Character. Polypidoms calcareous, massive, orbiculated, or lobed, or divided dichotomously; the cells long and tubular, with a round, prominent, unconstricted aperture-Dr. Johnston.

\section{Genus XXXV. TUBULIPORA, Lamarck.}

Gen. Char. Polypidom depressed, circular or lobed, adherent by a thin calcareous basis; cells clustered, inclined to be rowed, erect or sub-horizontal, more or less free at the round terminal aperture.-Johnston.

* With a thin sessile basis. (Discopora, Fleming.)

1. Tubulipora patina, Pallas.

Hab. On shells and zoophytes and seaweeds from deep water. Miss S. Beever, Isle of Man; Mrs. Gulson, Exmouth; Mrs. Gatty, coast of Yorkshire; Miss Allardyce, Cromarty.

This is a handsome little zoophyte. On our west coast it is chiefly found in the tangled roots of Laminaria digi- 
tata; at times, however, on stones and shells from deep water. It is occasionally cupped, but more generally it is shallow, like a saucer. Its largest size is about half an inch; with us it is less. It is calcareous and snow-white. The margin is plain and entire. The series of tubes or cells nearest the margin have plain angular apertures, like a honey-comb. The inner cells are tubular, and in rows.

2. Tubulipora inspida, Corliner.

Hab. Parasitical on Flustre and other seaweeds; also on shells and rocks. With us, on the west coast of Scotland, T. hispida, in its common form, is far from being rare, and it is got most frequently on Delesseria sanguinea; but larger and finer specimens are found, at times, on the roots of the large tangle and on shells from the deep. The broadest specimens I have met with were on Pinna ingens, from the island of Tiree. I liave a special regard for this little zoophyte, as it gave rise to what has been, to me, a very pleasant and profitable correspondence with my excellent friend, Dr. George Johnston, the well-known author of the 'History of British Zoophytes,' and many other valuable works on different branches of Natural Science. When he was preparing his first edition of the 'History of Zoophytes,' he wrote to me, saying, that he had observed, in my 'New 
Statistical Account of the parish of Stevenston,' of which I was then minister, that I had got Discopora verrucaria on the Ayrshire coast; and as he had not fallen in with it on the coast of Berwickshire, he would take it kind if I would send it to him;-which I was most happy to do. Dr. Fleming's generic name was Discopora, and he made it consist of two species, D. verrucaria and D. hispida. Dr. Johnston formed two species of the Discopora or Tubulipora; the first, T. patina, which seems a very distinct species, and the other, T. Rispida, which includes a portion of Dr. Fleming's D. verrucaria, viz. T. patina, and also his D. hispicla, which was regarded by Dr. Fleming as distinct from $D$. verrucaria. Though no friend to the multiplication of species, we should rather be disposed to make three species instead of two. T. patina seems very distinctly one species; and then we would have retained the specific name of verrucaria for that state of it which is truly wart-like, marked however by reticulated grooves; and to those specimens which have not these grooves, but have the denticles elongated into strong sharp spines, rendering the surface quite rough, we would have been disposed to give the name of $T$. hispida.

The little var. $\beta$ is very common on some saccharine 
(Laminaria saccharina) dredged in Lamlash Bay. It was long known to us under the name of T. orbiculus.

\section{** Base elongated or incrassated.}

3. Tubulipora Penicillata, $R$. Q. Couch.

Hab. On shells and stones from deep water, common; from the Eddystone Lighthouse to the Deadman Point, R. Q. Couch.

Mr. Couch describes it as calcareous, and about a quarter of an inch in height. The upper part is expanded into a flat head, having on its superior surface one or two rows of projecting tubes round the circumference; the centre is either plain or marked with a few irregular cells. The cells are distant from each other, with slightly oblique unarmed apertures. The under surface of the head is furrowed, without cells, and sloped into the footstalk." (See Dr. Johnston's plate xlviii. fig. 1, 2.)

4. Tubulipora truncata, Jameson.

Hab. Shetland Islands, Jameson; in deep water, Zetland, Dr. Fleming; Zetland, Prof. E. Forbes; Rev. T. Hincks, Salcombe, on shells.

The head is stellate; the top is convex, orbiculated, furrowed with shallow grooves, which run towards the flattish summit. It has been compared to a little Echinus without 
spines. It is not unlike a little round pie. (See Dr. Johnston's plate xxxiii. fig. 8, 9.)

*** Polypidom lobed; base unmargined.

5. Tubulipora lobulata, A. II. Hassall.

Hab. Dublin Bay, Hassall.

Dr. Johnston and Mr. Wr. Thompson are disposed to consider this as a very aged variety of Tubulipora serpens.

6. Tubulipora phalanges, $\boldsymbol{W}$. Thompson.

Hab. On rocks, shells, and seaweeds. Rev. T. Hincks, Salcombe, on shells.

Mr. Peach finds it very fine in the bulb of Laminaria bulbosa. Te liave found it fine in the inside of old bivalve shells. It is about four lines in diameter, in general; but Mr. Peach has seen it nearly an inch. It is somewhat like a pentapetalous flower, being slightly lobed. As the tubes are arranged in perpendicular rows, Mr. Couch says it presents the appearance of a number of Pan's pipes. It is of a pale purple colour; thin and glossy.

7. Tubulipora flabellaris, $\boldsymbol{I}$. Thompson. (Plate $\mathrm{IV}$. fig. 50.$)$

Hab. On Laminaria on the Irish coast. Salcombe Bay, Rev. T. Hincks, Exeter.

We have found it, on the Scottish coast, on the inside of 


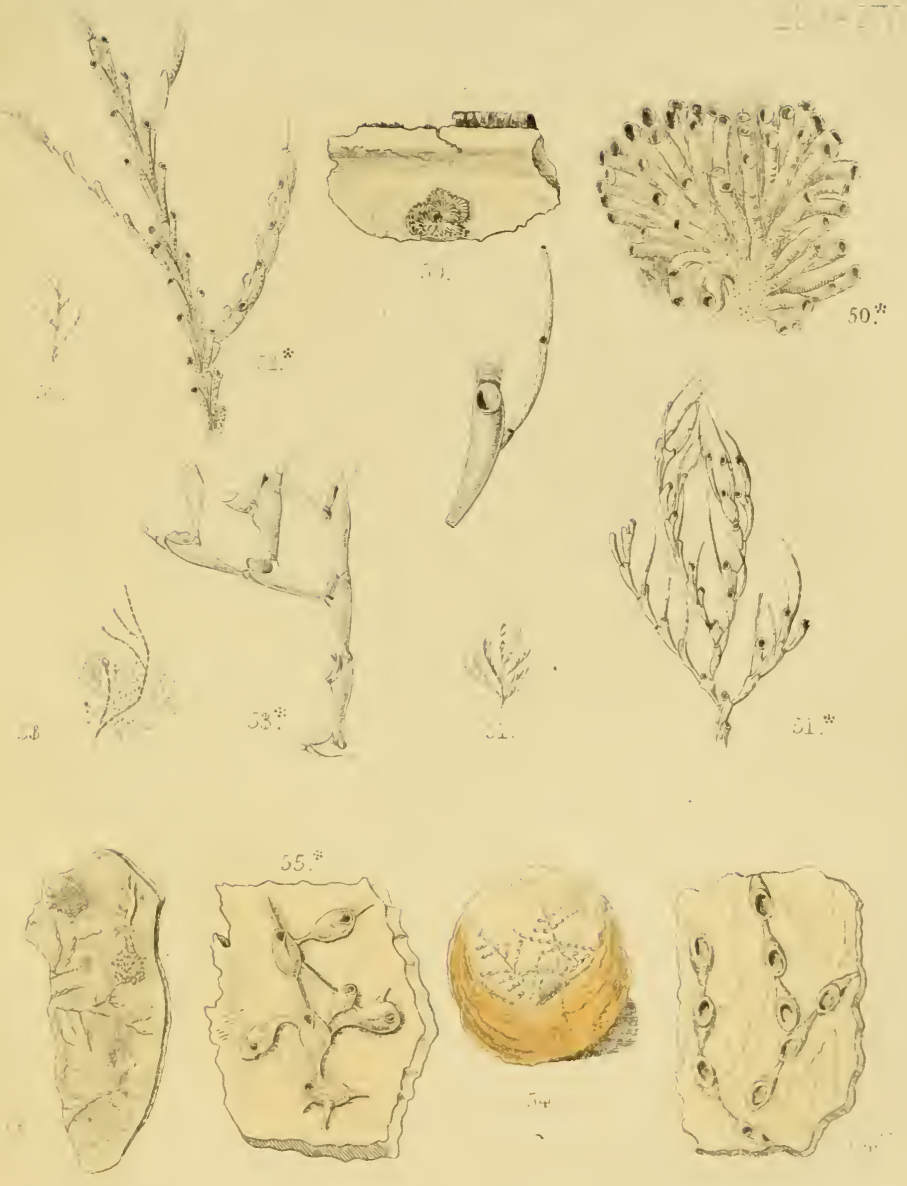



old bivalve shells. It is even prettier than the preceding, and so like the Prince of Wales' feather, that you are disposed to write "Ich dien" underneath. It is described also as fan-shaped, adherent by a thin plate, and only about the third of an inch in diameter. Mr. W. Thompson, who has met with it in Ireland and England, describes it as follows:- "It forms a beautiful incrustation, which takes the figure of a feather, or of several feathers combined, and is of a dull opake white colour, except at the margin, where the tubes are somewhat transparent and delicately tinged with pale lilac. The tubes are transversely wrinkled or ridged, - an appearance which increases more than in a regular ratio as the species approaches a perfect state; the space between the tubes is likewise rugose."

8. Tubulipora serpens, Ellis.

Hab. On all places of the coast; adhering to seaweeds, corallines, shells, and often in the inside of old shells. The first specimen to which my attention was ever directed was sent to me, from Portpatrick, many years ago by my friend the Rev. Andrew Urquhart.

It adheres by a narrow base; the polype-tubes are in transverse rows, divided by a longitudinal groove; the cells are in general placed close to each other, minutely frosted, 
and either white or of a light purple colour. It is seldom more than half an inch in length.

9. Tubulipora hyalina, R. Q. Couch.

Hab. On Fucus palmatus, Polperro, Couch.

"Encrusting in small semi-transparent patches of about the diameter of a pea. The cells are distant, erect, arranged in one or two rows round a plain centre."

\section{Genus II. DIOSTOPORA, Lamouroux.}

Gen. Char. Polypidom calcareous, encrusting, undefined; the cells alternating, tubular, horizontal, immersed, with a raised circular aperture.-Johnston.

1. Diastopora obelia, Dr. Fleming.

Hab. Scarborough, Mr. Bean; Berwick Bay, Dr. Johnston; Cornwall, Mr. Couch; Devonshire, Mrs. Gulson and Mr. Peach; Salcombe Bay, very fine on scallop-shells, Rev. T. Hincks; Yorkshire coast, Mrs. Gatty; Irish coast, Mr. IV. Thompson; off Sana Island, Mr. Hyndman; island of Tiree, Hcbrides, D. L.

The crust is thin, and adheres so closely to the shell on which it grows, that it cannot be removed from it without breaking it in pieces. The cells are pretty much immorsed; 
the mouths are raised, with a round oblique plain aperture. The finest and largest specimens I have seen were on the valves of Pecten ingens, from the islands of Tiree and Coll, sent to me by my friend, the Rev. A. Nicol.

\section{Genus III. IDMONEA, Lamouroux.}

Gen. Char. Polypidom calcareous, divided dichotomously, erect, celluliferous on one side only; cells tubular, in transverse rows, divided into two sets by a medial longitudinal line.

1. Idmonea Atlantica, E. Forbes.

Hab. Zetland Seas, Prof. E. Forbes; island of Coll, D. L., from the Rev. Mr. Nicol.

Erect, white, firm, dichotomous; branches spreading laterally; the cells tubular, forming a series of transverse rows on each side of the coral; the rows are on one side alternating with those of the other. Four-tenths of an inch in height. This is one of the numerous discoveries of Professor E. Forbes, who has another species from the Egean Sea, somewhat similar to the I. Atlantica; and in the collection of Mr. Stokes there is one from Kamtchatka. 


\section{Genus IV. PUSTULIPORA, Blainville.}

Gen. Char. Polypidom calcareous, erect; the divisions cylindrical ; polype-cells semi-immersed, arranged on all sides, tubnlar, with more or less prominent apertures.-Dr. Jolnston.

1. Pustulipora proboscidea, E. Forles.

Hab. Zetland Seas, Prof. E. Forbes.

"Cells nearly immersed, with everted free tubular extremities, alternate, four completing a whorl."

2. Pustulipora deflexa, R. Q. Couch.

Hab. On shells from deep water, Polperro, Mr. Couch; Plymouth, Mr. Bellamy.

From a quarter to half an inch in height. Calcareous, white, cylindrical. Dr. Johnston says, "I am tempted to ask whether this may not be a state of Tubulipora serpens." We have not seen it.

" There are deep thoughts of tranquil joy

For those who thus their minds employ,

And trace the wise design that lurks

In holy Nature's meanest works."

\section{Genus V. ALECTO, Lamouroux.}

Gen. Char. Polypidom calcareous, crecping, adnate, irregularly branched, formed of horizontal tubular cells, produced in a linear 
series, the upper portion of the cells erect, with a circular entire aperture.-Johnston.

1. Alecto granulata, $W$. Thompson.

Hab. On the inner surface of old bivalve shells, more rarely on the outer surface. It is a deep-water species. It is said to be not uncommon; but the only specimen we have met with was on the outer surface of Pinna ingens, from the island of Coll.

It is slender, branched, adherent, the tubular cells leaning a little to the opposite side. It is glossy, when fresh, and dotted with minute granules. When in a dead state, it is of a dull white colour.

2. Alecto major, D. L. (Plate XVI. fig. 60.)

Hab. Island of Coll, D. L., from Rev. Mr. Nicol ; island of Sana, dredged by W. Thompson; Cornwall, Mr. Couch.

This was a species new to our Fauna when I discovered it on a valve of Pinna ingens, from Coll. I sent it to Dr. Jolinston, and he mentions, in his description of it, that I said that the young unbranched specimens resembled a tear slowly trickling down the cheek, and swelling in its progress. Full-grown specimens, however, are irregularly branched, though each branch has the fulness we have mentioned, at the termination. It is much stouter and 
more conspicuous than the preceding species, and can scarcely escape observation. It adheres, also, more firmly to the shell on which it grows, the basis spreading beyond the cells, and the cells are unmarked with granules.

3. Alecto dilatans, $\boldsymbol{W}$. Thompson.

Hab. Island of Sana, dredged by Mr. Hyndman; coast of Northumberland, Prof. W. King; dredged off the Mull of Galloway, in from 110 to 140 fathoms, by Professor E. Forbes; island of Islay, Lady Emma Campbell.

This is a pretty species, as may be seen in Dr. Johnston's plate xlix. fig. 5, 6. It creeps along on the surface of bivalve shells in a branching manner, each branch being fullest at the top, as in the preceding species. The cells are tubular, and a good deal immersed; they are also marked with granules. Dr. Johnston says that he has sometimes thought that it might be a state of Diastopora obelia. We have seen it in circumstances which thoroughly convinced us that it was quite distinct from $D$. obelia. Some time ago my friend the Rev. Mr. Nicol, of Coll, sent me some valves of Pinna ingens, dredged from deep water by the fishermen of that island. I valued the Pinna, but I prized much more the zoophytes that were parasitical upon it. There were various fine Lepralice, some of them in the 
broadest patches I had ever seen; there was much of the shell covered with Hippothoa catenulata, much larger in size than I had ever met with it before; there was one specimen of Hippothoa divaricata; one of Alecto gramilata; several of Alecto major, and three or four of Alecto dilatans; one of what we thought was Pustulipora deflexa, and many fine specimens of Diastopora obelia; and as these were located alongside of Alecto major and Alecto dilatans, they were, at a single glance, seen to be so different, that I should never have thought of comparing them. Alecto major and Alecto dilatans may run into each other, but Diastopora obelia, in its pretty, continuous, unbranched scurf, is evidently, I humbly think, different from any of the three species of Alecto.

\section{FAMILY CRISIAD瓜.}

Character. Polypidoms phytoidal, jointed, dichotomously branched; the cells tubular, disposed in one or two series, with the circular apertures alternately looking to opposite sides.Johnston.

Genus VI. CRISTA, Lamouroux.

1. Crisia eburnen, Ellis. (Plate XV. fig. 52.) 
Hab. Very common on seaweeds, such as Dasya coccinea and Delesseria sanguinea; common also on other zoophytes.

This ivory-tufted coralline, though generally as white as ivory, from which it takes its specific name, is occasionally tinted with rosy-red. It is much branched, nearly half an inch in height; cells in two rows, sometimes nearly alternate, at other times opposite. Pear-shaped vesicles are scattered over the branches, finely granulated.

2. Crisia denticulata, Dr. Fleming.

Hab. On seaweeds and corallines, like the preceding, but not nearly so common. It is not rare on the coast of Ayrshire, but it is smaller in size than specimens from England and Ireland. The finest specimens I have are from Miss S. Beever, and from Mr. Tumanowicz, Hastings. They are above an inch in height, and as much in breadth. Its larger size and stouter texture, and still more its black joints, which give it a spotted appearance, enable even the naked eye to distinguish it from the preceding; with which, nevertheless, it was confounded, till Prof. J. Fleming pointed out the difference.

3. Crisia aculeata, A. M. Hassall.

Hab. Kingston Harbour, Mr. Hassall; near Larne, Mr. R. Paterson; Ballantrae, Ayrshire, Mr. IV. Thompson. 
Mr. Hassall describes it as follows :- "Cells disposed in a double series, armed with a long spinous process; joints of an amber-colour; vesicles much resembling a fig in shape, and dotted." Mr. W. W. Saunders says that it is not uncommon at Brighton and Hastings; but he considers it as the perfect state of Crisia eburnea.

4. Crisia geniculata, J. J. Lister.

Hab. On littoral algæ, Brighton, Lister; on Rytiphlaa pinastroides, Brighton, W. W. Saunders; Strangford Lough, W. Thompson; Ayrshire coast, D. L.

Dr. Johnston states that this differs from Crisia eburnea in being more slender and less calcareous; -in the straightness of the secondary branches, and in the tubular form of the cells, which are alternate and free at the apices. I do not think that the specific name given it by Milne Edwards is very characteristic, for, as Dr. Johnston states, it is only subgeniculate. He thinks that the characters which distinguish it from C. eburnea are rather those of a variety than of a species. I have sometimes thought so too; and yet $\mathrm{I}$ am, on the whole, disposed to regard it as distinct. On the Ayrshire coast $C$. eburnea is found on almost everything, whereas $C$. geniculata is scarcely ever seen except on Desmarestia aculeata, which is often quite hoary with 
its numerous tufts, which are smaller and of a duller white than those of $C$. elurnea.

\section{Genus VII. CRISIDIA, M. Edwards.}

Gen. Char. Cells linked in a single series; the upper portion free and divergent.-Johnston.

1. Crisidia coinuta, Goat's-horn Coralline. (Plate XV. fig. 51.)

Hab. On other corallines and on seaweeds beyond lowwater mark.

Ellis, who gives a good figure of it, says, "This rery small capillary coralline consists of branches of single cells, shaped like goats' horns inverted, placed one above another, on the top of which is a sinall circular opening, which inclines inwards. At the back of this rises a fine upright hair, near the insertion of the next cell abore it." It has oval-shaped vesicles, which are specked. The long bristles are sometimes jointed; but we have not observed them so in the West, where it is often found, especially on Delesseria sanguinea.

2. Crisia setacea, $R$. Q. Couch.

Hab. Shores of Devon and Cormwall, Couch; Salcombe, Rev. T. Hincks. 
This, according to Mr. Couch, is distinguished from the preceding by having the bent necks of the cells turned in opposite directions, and the bristle below, instead of above, the orifice. We had never seen this till it was kindly sent to us from Exeter by the Rev. T. Hincks.

\section{Tribe 2. CELLIPORINA. \\ Family EUCRATIADA.}

Character. Polypidoms calcareous, confervoid, multiform; the cells elongate, enlarged upwards or clavate, with an oblique subterminal aperture, the rim of which is always plain; no external ovarian capsules*.-Jolnnston.

"Under the bowers

Where the ocean Powers

Sit on their pearled thrones;

Through the coral woods

Of the weltering floods,

Over heaps of unvalued stones;

Through the dim beams

Which amid the streams

Weave a net-work of coloured light;

And under the caves,

Where the shadowy waves

Are as green as the forcst's night." - Shelley.

* Mrs. Gatty, of Ecclesfield, has discovered capsules on Hippothoa divaricata; Mr. Peach thinks he has discovered them on $H$. catenularia. 


\section{Genus VIII. EUCRATEA, Lamouroux.}

Gen. Char. "Polypidom conferroid, jointed, subcalcareous; the branches consisting of a single row of bent cells, the orifices of which are on one aspect, oblique, subterminal or lateral."

\section{Eucratea chelata, Ellis. (Plate XV. fig. 53.)}

Hab. Brighton, Mr. W. Wr. Saunders; Hastings, Mr. Tumanowicz; Devonshire, Rev. T. Hincks; Scarborough, Mr. Bean; Cork Harbour, J. V. Thompson; Ayrshire, D. L.

Ellis gives the following description of it:- "This beautiful coralline is one of the smallest we meet with. It rises from tubuli, growing upon Fuci; and passes from thence into sickle-shaped branches, consisting of simple rows of cells, looking, when magnified, like bulls' horns inverted, each one arising out of the top of the other. The upper branches take their rise from the fore part of the entrance of a cell, where we may observe a stiff short hair, which seems to be the begimning of a branch. The opening of each cell, which is in the front of its upper part, is surrounded by a thin circular rim; and the substance of the cells appears to consist of fine transparent shell or corallike substance." The cells taken separately are not unlike a slipper, though the mouth would require to be a little 


\section{Shet X...}

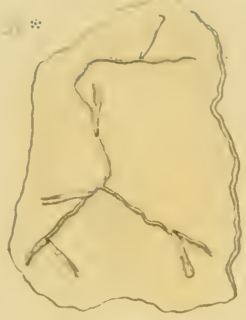

닌

(ive

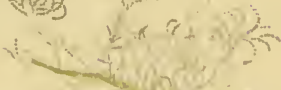

(ii) $\frac{\pi}{7} \mathrm{n}$

i)

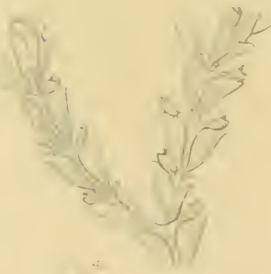

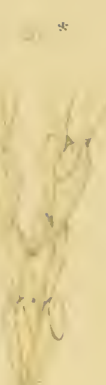
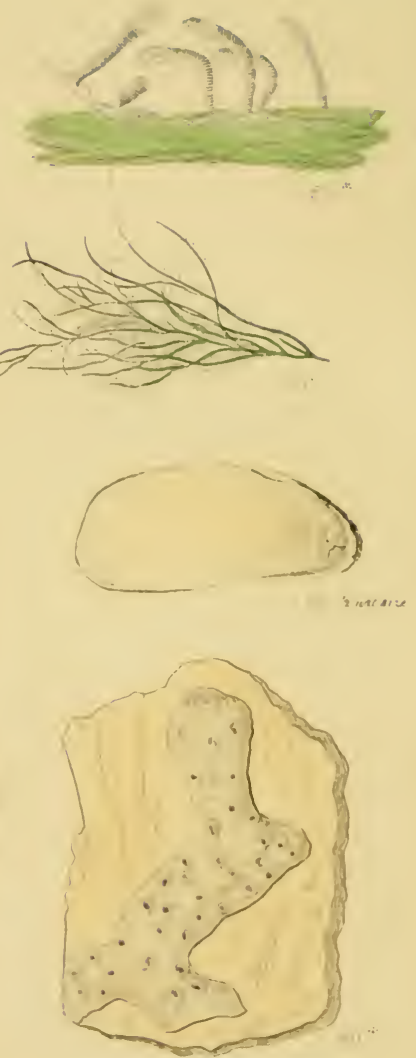

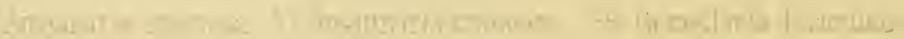

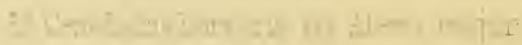


elastic to admit the foot. Dr. Johnston states, on my authority, that it is frequent on the coast of Ayrshire. I must have made some mistake in giving this information, for it is rather rare. It abounds, however, on specimens of $R y$ tiphlea pinastroides, sent to me from Hastings by Mr. Tumanowicz; also, on the same alga, received from Miss S. Beever and Mrs. Gatty.

\section{Genus IX. ANGUINARIA, Lamarck.}

Gen. Char. Polype-cells spathulate, erect, scattered, with a lateral aperture near the apex, originating from a creeping, fistular, sub-calcareous fibre, adnate to a foreign base. Polypes Ascidian.-Jolnnston.

1. Anguinaria spathulata, Ellis. (Plate XVI. fig. 56.)

Hab. Coast of Treland, W. Thompson; coast of Yorkshire, Mrs. Gatty ; Salcombe, Rev. T. Hincks ; coast of Ayrshire, D. L.

This has been called Suake Coralline, from its shape, or because, like a snake, it creeps in a winding way along the stems of such seaweeds as Dasya coccinea or Rytiphlaa pinastroides. "From very small holes, in the broadest part of the irregular winding tube, there arise here and there small, testaceous, white, hollow figures, exactly resembling 
a snake without the lower jaw,-in the place whereof is the entrance into the cell." (Ellis.) Dr. Johnston states that it is of a pale pink, or flesh-colour, or white. It is rare in Scotland; and the specimens we have seen were white, and so were all that we have seen from England; but they may have been coloured in a fresh state. It is smooth and glossy, but the snake-like tube is marked all along by numerous annulations of a more opake aspect. Mrs. Gatty was the first to point these out to me; but they are very conspicuous in a figure of it with which I lave been favoured by Mr. Busk, of Greenwich, whose forthcoming work on the Polyzoa is eagerly looked for.

2. Anguinaria truncata, milii. (Plate XVI. fig. 57.)

Hab. Lamlash Bay, Arran, on Laminaria saccharina.

I am glad to state that this is a new species added to our Fauna. When I had the pleasure of a day's dredging in Lamlash Bay, in September, along with Professor Balfour of Glasgow, and other friends, I observed that a large frond of Laminaria saccharina, which the dredge brought up, was roughened with little bristles, and, tearing off about a foot of the frond, I deposited it in my vasculum for more leisurely examination. On reaching home, when I began to inspect it I saw that the little bristling tubes that had 
attracted my attention, were not distinct polypidoms, but little tubular pores, springing from a fistular fibre, which ran in an irregular line along the frond, adhering closely to it. This creeping fibre, at pretty regular intervals, spread out into cells in the form of Hippothoa; and from the blunt end of the enlargement the tubular spores arose, of the same texture as the creeping fibre, and showing the reddishcoloured remains of the polype that had inhabited them. It was unlike anything I had seen before. In reading Mr. Couch's description of his Hippothoa sica, I found that he said, "the apertures are rather small, and as usually seen are round, even, and unarmed; but, in recent and living specimens, they are long and tubular, frequently as long as the cell. In this state it may be taken for a species of Tubulipora." This description in part suited my little creeper, but it was deficient in the regular symmetry of Hippothoa. Could it then be Anguinaria on a flat frond? The upright pores were not bent like $A$. spathulata, and showed nothing of the serpent-like head. They were like a small quill cut across, and then a longitudinal slice cut off towards the top, as the first step in the process of making the quill a writing-pen, so that it was open so far like A. spathulata, but unbent; and truncated instead of 
bent and anguiform. I sent specimens of it to several of my zoophytological correspondents, but not one of them said anything about it, and conjecturing that it might be some common thing in an imperfect state, I neglected it, and either lost or mislaid my remaining specimens. When I required to say something about Anguinaria in this little book, I bethought myself again of my little straggling creeper, and remembering that I had sent a specimen of it to Mrs. Gatty, of Ecclesfield, I requested her to send it to Mr. Busk, of Greenwich, with whom she was in correspondence, and I soon had a kind letter from him, stating that it was an Anguinaria, similar to, if not identical with, his Anguinaria ligulata, which Mr. Darwin brought from Tierra del Fuego, where it creeps in the same manner on broadfronded algæ. The only difference was, that his had a contraction where the pore begins to be laid open. He sent me a drawing of the one from Lamlash Bay, and also a figure of Anguinaria ligulata from the South Seas. They are remarkably similar, with this difference, that in upwards of a hundred pores or cells which I examined of our Scottish one, there was not a single instance of their being constricted. At all events, Mr. Busk says that it is new to our Famna. He has, since I wrote the above, examined it again; and as 
he now considers it distinct, he has given it the specific name (truncata) which I suggested.

There was, along with the figure of $A$. spathulata and $A$. ligulata, the figure of another Anguinaria. I was glad to see it and to get the name of it, for I had got very fine specimens of it on a beautiful alga from Port Phillip, which I received from my kind friend Dr. D. Curdie. I saw that it was quite distinct from our British $A$. spathulata, and superior to it both in size and in beauty. Instead of terminating like a surgeon's spatula or a serpent's head, it was shaped exactly like a ladle, the open part at the top spreading out and becoming quite circular. Though I have a good collection of foreign zoophytes, I have few books in which they are described and tigured; so that they either remain unnamed, or have temporary names assigned. To the ladleshaped one I gave the interim name of $A$. cochlearis, so that I was very glad to receive from Mr. Busk an excellent figure of it under the true name $A$. dilatata.

\section{Genus X. HIPPOTHOA, Lamouroux.}

Gen. Char. Polypidom conferroid, adherent and creeping, calcareous, irregularly branched, the branches frequently anastomosing, formed of elliptical cells linked to each other at 
the extremities; aperture lateral, near the distal end. Polypes Ascidian.-Johnston.

1. Hippothoa catenularia, Profissor Jameson. (Plate XV. fig. 54.)

Hab. On shells, especially bivalves, from deep water.

This is a very handsome little coralline. Dr. Johnston very properly describes it as "formed of a series of cells commected like a string of bugles; cells oval, widest and rounded anteally; its aperture oval, with a plain thickish rim placed near the top." Mr. Gray states, that when alive "it appears like dew-drops, and is easily separated from the shell by a pin, but is strongly attached when dry." We have observed this, and also what Dr. Johnston mentions, that in this state (when dry we suppose) the aperture of the cells is sometimes closed by a membrane. 'This was very evidently the case with respect to many of the largestsized examples we ever met with. 'They were on the valves of Pinna from island of Coll. The cells were large, and the branches, having full scope, covered about three inches of the shell in length by about an inch and a half in breadth, and many of the cells had this membranous covering of the aperture by a calcareous deposit rendered as thick as the cells. 
2. Hifpothoa divaricata, Miss Elliott. (Plate XV. fig. 55.)

Hab. On old shells, especially bivalves, from deep water. - On oyster-shells, Sidmouth, Mrs. Gatty ; on:Pinna, from the island of Coll, D. L. ; on different kinds of algæ, coast of Ayrshire, D. L.

This is so delicate and slender that it requires good eyes to observe it; and when it is old and opake, and on a whitish shell, an unpractised eye, even when aided by a lens, would scarcely succeed in detecting it. When young and fresh it has a crystalline appearance; the cells, which are connected by a delicate calcareous thread, are more distant from each other than those of $H$. catenularia. Dr. Johnston mentions that there is "a variety of $H$. divaricata in which the cells are contiguous. It is found on seaweeds only, so far as my experience goes." This accords with my own experience in so far that I have seen on seaweeds the pretty little variety with a very short thread betwixt the cells; yet the very last specimen of II. divaricata which I fell in with was on Delesseria sinuosa, as transparent almost as dew, while the portion of thread which connected the sparkling bugles was fully as long as I had ever seen it upon shells. 
But I am happy that I have something new to record respecting this miniature moniliferous coralline. It is not in its right place, but must be raised a step higher. You will observe that it is one of the characteristics of the family of Eucratiade, in which it is now ranked, that "they have no external ovarian capsules." But it has lately been discovered by Mrs. Gatty, of Ecclesfield Vicarage, that II. divaricatu has external ovarian capsules. Her eyes are brighter, and, as we would say in Scotland, glegger* than those of our masculine naturalists, and much bother she had, as our Irish friends would say, to cause them to see the capsules after she had seen them herself. But now Dr. Jolnnston has seen them, and Dr. Greville has seen them, and Mr. Busk has seen them, and I have seen the fine globular capsules at the end of the cells, which are very obvious after they have once been detected.

3. Hippothoa sica, R. Q. Couch.

Hab. On stones from deep water, common. Polperro, Goram, R. Q. C.

* When a person is very elever and very acute, we say that he is very gleg; so that gleg-eyed is sharp-sighted, clear-sighted, quick-sighted,lynx-eyed. Sinee I wrote the above Mr. Peach has mentioned to me that the capsules of $I$. divaricata have been known to him for some time. $-D . L$. 
"This species differs so decisively from the two preceding, that there can be no doubt of its being specifically distinct. The cells are calcareous; enlarged, and rounded at the distal, and pointerl at the proximal end. Their direction is linear; they are attached to each other at their extremities, and their length is about four times their transverse diameter." (R. Q. Couch.)

4. Hippothon Cassiterides, Couch.

Hab. "On a stone betwixt the Scilly Islands and the Land's-end." "The cells are stouter and more pear-shaped than in H. divaricata, and the threads of connection shorter and stouter." "At a short distance from the proximal lip is a small pearly tubercle, which is larger in one cell than another." "This tubercle is very different from anything ever observed in $H$. divaricata, and constitutes it a distinct species." (R. Q. Couch.)

\section{Genus XI. GEMELLARIA, Savigny.}

Gen. Char. Polypidom plant-like, sub-calcareous, rather soft and flexible when dry, much branched dichotomously: cells geminate, exactly opposite, united back and back with a thick dissepiment, a joint above and below each pair. Polypes Ascidian, with elongated tentacula; no gizzard.-Dr. Johnston. 
1. Gemellaria loriculata, Doody. (Plate X VI. fig. 55.) Hab. A few fathoms beyond low-water mark.

"This coralline, which grows in very large tufts and bunches, consists of many long, shining, soft, and slippery branches. These are composed of joints of cells placed in pairs back to back. The opening of each is on a slant near the top, and looks the contrary way to the other; so that the pair together resembles a coat of mail or a pair of stays, and the entrances of the cells look like the places for the arms to come out at." (Ellis.)

Dr. Johnston, in describing it in his second edition, says, "Common, but Mr. Landsborough has never found the smallest scrap of it on our western coast." This statement still holds true as to our western, but not our south-western coasts. In a very pleasant excursion to Kirkcudbrightshire, some time ago, I visited, along with the Rev. Dr. Paterson, of Glasgow, the Rev. Mr. Smith, of Borgue, and the Rev. Mr. M'Millan, of Kirkcudbright, the lighthouse on the island called the Little Ross, and no sooner had I landed from the boat than I saw floating in the little creck great abundauce of a coraline, which I was sure I had not met with on our Ayrshire coast. I collected a great quantity of it, and I was glad to find that it was Gemellaria 
loriculata. It is not easy to account for the abounding of certain species on some coasts, and the entire absence of these very species on other coasts at no great distance.

\section{Genus GEMICELLARIA.}

1. Gemicellaria Bursaria, Blainville. (Plate XVI. fig. 59.)

Hab. On seaweeds and corallines. Devonshire, Mrs. Griffiths; Mr. Peach, Isle of Wight; Mr. Wigham, coast of Norfolk; Mr. J. B. Hall, Isle of Wight.

Nothing can be better than the description of Ellis, who also gives an excellent figure of it in plate xxii., under the name of the shepherd's-purse coralline. "This most beautiful pearl-coloured coralline adheres by small tubes to Fuci, from whence it changes into flat cells; each single cell like the bracket of a shelf, broad at top and narrow at bottom : these are placed back to back, in pairs, one above another on an extremely slender tube, which seems to run through the middle of the branches of the whole coralline. The cells are open at top. Some of them have black spots in them; and from the top of many of them a figure seems to issue out like a short tobacco-pipe, the small end of which seems 
to be inserted in the tube that passes through the middle of the whole. The cells, in pairs, are thought by some to have the appearance of the small pods of the shepherd'spurse ; by others, the shape of the seed-vessels of Veronica, or speedwell."

Dr. Johnston states that it is very rare, and that he is indebted for his much-prized specimens to Mrs. Griffiths.I am rather surprised that it should so long have been thought rare, for I am persuaded that in the south of England it is far from being uncommon. The first specimen that I ever met with was on Rytiphlaa pinastroides sent to me from Brighton by Mr. Pike, and as he had not mentioned that it was on the seaweed, I was delighted on discovering it. I soon after received it from M. Tumanowicz from Hastings, on the same seaweed; and, ere long, I found several specimens on Dasya coccinea, from Mr. Hall, of Coggeshall, among seaweeds from the Isle of Wight; then I received several specimens from Mr. Wigham, which he had found on Rytiphlaca pinastroides at Hastings, and lately he sent me half-a-dozen specimens, saying, that he had collected about a score at Cromer. Rytiphlaa pinastroides seems its favourite weed, and it certainly makes no great figure among its robust branches; but from the 
number of little bittocks which I have detected on various weeds from the south of England, it is evident that it is not rare.

\section{FAMILY CELLIPORID君.}

"Seas have (as well as skies) sun, moon, and stars, (As well as ayre) swallows and rooks, and stares, (As well as earth) vines, roses, nettles, melons, Pinks, gilliflowers, mushrooms, and many millions Of other plants (more rare and strange than these), As very fishes living in the seas, And also rams, calfs, horses, hares and hogs, Wolves, lions, urchins, elephants and dogs, Yea, men and maids : and (which I more admire) The mytred bishop, and the cowled fryer." -Du Bartus.

Genus XII. CELLIPORA, Otho Fabricius.

Gen. Char. Polypidom calcareous, cellular, irregularly lobed or ramous, formed of urceolate cells heaped together or arranged in quincunx. Polypes Ascidian.—Johnston.

1. Cellitora pumicosa, Ellis.

Hab. Found on corallines, stones, shells, roots of algæ; very common.

This is called by Ellis, porous Eschara; often found on the sickle coralline in irregular lumps, appearing like white 
sand strongly united together, and in the microscope it looks like a pumice-stome. It forms a porous, friable, calcareous mass. It is very seldom an inch in length, but very common in small patches, sometimes pink or purple, but generally on the $\Lambda$ yrshire coast dirty-white. When in good state the aperture has a tocth above, and sometimes a small one on each side. It is one of the least interesting of our corallines.

2. Cellipora ramulosa, Pallas. (Plate XVII. fig. 61.) Hab. In deep water, attached to old shells.

This, though considered by some as a variety of the latter, cannot fail to attract attention, for it is like some of our foreign corals in miniature, rising in a branching form to the height of two or three inches, so that even our fishermen deign at times to preserve it as a pretty curiosity; though, being brittle, it is very apt to be broken in their hands. The branches are very rough with toothed cells.

3. Cellipora Skevil, Di. Duvid Skene.

Hab. On shells and corallines, deep water. Aberdeen, Skene; Zetland, rare, Dr. Fleming; coast of Northumberland and Berwickshire, not rare; on Pinna, off the Deadman, Couch ; eastern coast of Ireland, Miss Ball.

It is from half an inch to an inch in height, much com- 

pressed, palmate, truncate. Dr. Johnston says, "Notwithstanding the apparent dissimilarity in habit of the three preceding Cellipore, I cannot but suspect that they are merely different states of the same species; for in these productions the 'fronti nulla fides' receives many an apposite illustration."

4. Cellipora cervicornis, Borlase.

Hab. In deep water, not rare, Fleming; Cornwall, Borlase; Devonshire, Dr. Coldstream; Shetland, Jameson; coast of Ireland, R. Ball ; Fifeshire coast, rare, J. Goodsir ; Roundstone Bay, M`Calla; Cumbraes and Arran, - Major Martin and D. L.

This is about three inches in height, and it spreads out greatly: it is fully more in breadth. The branches are much compressed, and truncate at the extremities, bearing a considerable resemblance to the antler of a stag. It differs considerably from $C$. ramulosa, in being a stouter fabric, and in having the branches flattened, and more kneed and spreading. It is rarer than C. ramulosa. It has often a varnished appearance.

5. Cellitpora lievis, Dr. Fleming.

Hab. Zetland, Fleming; Cornwall, Couch.

According to the descriptions given of it by Dr. Fleming 
and Mr. Couch, the former of whom fell in with it in the northern, and the latter in the southern extremity of Britain, this Cellipora is inferior to the last in height and breadth, of a more delicate fabric, and whiter in colour.

6. Cellipora vitrina, C. W. Peach.

Hab. Goran, Mr. Peach; Mount's Bay, Mr. Couch.

"This delicate and beautiful species is very small: it is encrusting, circumscribed, and rarely exceeding a quarter of an inch in diameter. The cells are small, transparent, vitreous or pearly in their appearance, and very irregularly arranged. The apertures are very minute and terminal, and cannot readily be seen even with a lens." (Couch.)

\section{Genus XIII. LEPRALIA, Jolnston.}

Gen. Char. Polypidom calcareous or membrano-calcareous, adnate, crustaceous, spreading circularly, formed of a layer of urceolate cells in juxtaposition, horizontal, and arranged in semialternating rows : aperture terminal, often covered with an opercular ovary.-Dr. Jolinston.

This is a very interesting genus, and a great favourite with zoophytologists, but it is an excessively puzzling one, owing to the minute points of distinction betwixt one spe- 
cies and another, and owing also to the different aspects which, from age and various other circumstances, the same species present. When Professor Fleming's 'British Animals' was published, in 1828, only five species were described. By the time Dr. Jolnnston's first edition of his work on British Zoophytes appeared, more than double this number were described and illustrated; and when the second edition of his ' History' was published, it contained the description of thirty-seven species; and the author states that, extensive as the list was, he liad specimens which he could not confidently refer to any of the species described. We know that several distinguished Naturalists are at present at work with these little beauties, exercising upon them all their powers of discrimination; and we are glad to learn that some of them intend to favour the public with the result of their investigations. We should be afraid to attempt describing the whole of these pretty little puzzlers; and though we had the boldness, the limits of our work would compel us to rest satisfied, in many cases, with doing little more than inserting the name.

* Wall of the cells smooth.

1. Lepralia hyalisa.

Hab. Parasitical on shells, stones, and algæ. Shores of 
Ireland, common, W. Thompson; on seaweeds, Cornwall, Mr. Peach; on different kinds of alga, Devonshire, Miss Cutler; on Phyllophora rubens, Isle of Man, Miss S. Beever, from Miss Hislop; on Laminaria saccharina, coast of Ayrshire, very common, D. L.

This, though common, is a pretty speeies. It appears most frequently, with us, in roundish patches of thin calcareous crusts. The cells are sub-cylindrical, and pellucid, with a few transverse plaits; they are often almost concealed by a great number of globular ovariau capsules. Lieutenant Thomas finds tiro varieties in Orkney; one with the cells touching, and the other with the cells separate, and the intermediate space punctured. We received a variety from Miss S. Beever, with bunchy ventricose cells, which we at first thought L. simplex, but the cells want the thickened rim.

2. Lepralia texuis, A. M. Hassall.

Hab. On rocks and shells. On Laminaria digitata, Dublin Bay, Mr. Hassall; Cornwall, Mr. Peach; on Pecten opercularis, off Sana Island, Mr. Hyndman; on P. varius, Sidmouth, Mrs. Gatty; on Laminaria saccharina, Lamlash Bay, D. L.

The cells are ovate and long in proportion to their 
breadth. When young, they are pellucid and smooth. The capsules are projected in front of the constricted aperture, and are perforated on the top. The cells are surrounded with a series of apertures.

3. Lepralia assmimlis, A. H. Hassall.

Hab. Dublin Bay, Hassall.

Though this resembles L. tenuis, Mr. Hassall thinks it is distinct. Dr. Johnston, . judging from Mr. Hassall's description, can see no characteristic difference betwixt them. Four specimens of it were got by Mr. Hassall on Pecten maximus.

4. Lepralta Hassallit, A. H. Hassall.

Hab. On shells, rare. Dublin Bay? A. II. Hassall ; on Patella carulea, coast of Ayrshire, D. L.

We remember finding this, many years ago, adorning the summit of a $P$. carulea, cast out on the shore at Saltcoats. It was new to me, and I sent it to Dr. Johnston, who was then preparing for the press the first edition of his ' History.' He received it afterwards from Mr. Hassall. It is composed of large cells, horizontal and cylindrical. The aperture is wide, with a small sinus above and a large knob on each side. The capsule, situated below the aperture, "minics the swollen lobe of the flower of a calceolaria." (Jolnnston.) 
5. Lepralia simplex, G. C. Myndman.

Hab. On various bivalve shells dredged at Sana Island, Mr. Hyndman, apparently not rare.

This resembles L. hyalina, but it is more bunchy, and it has a raised and somewhat thickened rim. There is a blunt knob behind the margin of the upper lip.

6. Lepralia ventricosa, A. H. Massall.

Hab. Dublin Bay, Mr. Hassall ; Cornwall, on old bivalve shells, Mr. Peach; Newhaven, Dr. Greville; Sana Island, Mr. Hyndman; near Irvine, D. L.

I have a good specimen of this, got at Newhaven by Dr. Greville, which has enabled me to name a specimen got on the inside of an old Buccinum undatum, betwixt Saltcoats and Irvine. The colour, like that of Dr. Johnston's and Dr. Greville's, is greyish-white; whereas Mr. Hassall's specimens, when dry, were brownish and glistening. The cells are ovato-globose, narrowed anteriorly, with a mucro in the centre of the proxinal margin. Capsules globular and roughish.

7. Lepralia Hyndmanit.

Hab. On the inner surface of an old shell of Pecten opercularis, and on other shells, dredged at Sana Island, Mr. Hyndman. 
Sana Island, off which this and several very interesting mollusks and zoophytes have been dredged, is near the coast of Cantire, in Argyleshire. This coast, from Macrihanish Bay to the Mull and Southend, is rich in algæ and zoophytes; but in visiting it some time ago, not having a boat, I had to rest satisfied with the rejectamenta on the strand; and there are few portions of the Scottish shores better fitted to gratify a naturalist. My friend, Mr. Hyndman, of Belfast, to whom this curious Lepralia has been dedicated by Dr. Johnston, has every encouragement to cross again to Sana. Ireland is scarcely more than twenty miles from Cantire, in the county of Argyle.

The cells of Mr. Hyndman's Lepralia are described by Dr. Johnston as "distinct, but contiguous, of a medium size, sub-globular, narrowed and somewhat raised anteriorly, the back smooth and thickish, but the base of the cells, or the space between them, is occasionally perforated with a series of punctures. The aperture has a neat and deep sinus on the proximal side, and the distal margin is plain and rounded. The stout, short, tubular process on the posterior side of the cell is always very obvious; and there issues from it a long slender bristle, which, however, is often broken away. Ovarian capsules proportionably small." 
The process on the side of the cell makes it very remarkable. (See Dr. Johnston's plate liv. fig. 6.)

8. Lepralia axsata.

Hab. On slaty rocks, Cornwall, Peach.

Cells ovato-globose, slightly punctured; aperture circular, with a sinus above. "On each side of the aperture a hollow auricle projects forwards; and, viewed in front, these auricles have a miniature resemblance to the ears of a fox or of a cat." (Johnston.) This is not a rare species, being found in the east and west of Scotland, and in the north and south of England.

9. Lepralia ovalis, A. H. Massall.

Hab. On dead bivalve shells. Kingstown and Burnham, Hassall ; coast of Ireland, Mr. W. Thompson; Devonshire, Mr. Peach and Dr. Greville.

The cells are oval and distinct; the aperture is circular, with a knob above, and two spines on the under lip.

10. Lepralia linearis, A. M. Massall.

Hab. On stones, east of Kingstown Harbour, and at the Giant's Causeway, Hassall ; Orkney, Dr. Greville.

I have before me an Orcadean specimen from Dr. Greville, on an old bivalve. It is a very perfect one. It is marked with lines, which are the boundaries betwixt the 
rows of cells. The aperture is small and circular, with a hollow tubercle on each side. The ovarian capsules are a little punctured, with a perforation on the posterior side.

11. Lepralia quadridentata, $A$. H. Hassall.

Hab. Ireland, Hassall; near Aberdeen, Macgillivray.

** IV all of the cells granulous.

12. Lepralia granifera, Dr. Johnston. (Plate XVIII. fig. 69.)

Hab. On slaty rocks, Holy Island, and Berwick Bay, Dr. Johuston ; Isle of Man, Prof. Forbes ; Cornwall, Mr. Peach ; Saltcoats, Ayrshire, D. L.

Dr. Johnston thinks this, in some respects, resembles $L$. tenuis; it bears some resemblance, also, to L. hyalina, but it has marks that distinguish it from both of them, as will appear from the following excellent observations with which Mrs. Gatty has obligingly favoured me.

"The varieties of $L$. granifera figured in the Plate seem to demand an explanation. The one marked $a$, was first found on Plyllophora rubens, from Portrune, in Ireland, in 1851, and the second variety, 6, was discovered by Dr. Greville the same year, on Phyllophora rubens, from Sidmouth. The horned variety has since been found at Sidmouth also. 
"Perhaps the typical form of $L$. granifera may be considered to lie between these two extremes. The extreme variety, $\beta$, lies flat to the seaweed, and is cut into a finely marked diamond pattern, round the four sides of which are a row of dots or punctures. There is also an opening below the mouth. The side dots rarely extend over the rest of the cell, but as they occasionally do so, and the species correspond in other particulars, it has not been thought reasonable to separate this beautiful variety from $L$. granifera. The pure transparency of the cell in its young condition-varied by a thicker line, which marks out its diamond shape, and in which lie the row of dots-makes it a very pretty object. It is so glassy in its texture that the colour of the red Phyllophora can be distinguished through the cell. As it advances in age, the opening below the mouth looks as if it was on a raised knob, and the flat appearance of the cell is gone.

"The figure of var. $a$ represents its extreme state in which the side horns and the heavy knob are so prominent as to be the leading features of the species. In modified instances the front protuberance is lower, and the horns less distinct. It is still, however, a very remarkable variety."

13. Lepralia Landoborovit, Dr. Johnston. 
Hab. On Pecten opercularis, coast of Ayrshire, D. L.

Dr. Johnston, in doing me the honour of dedicating this Lepralia specifically to me, accompanies the compliment with language dictated by all the partiality of friendship. "Laudari à laudato" would be very sweet, were there not a depressing sense of great shortcomings. When on another occasion a friend had given the specific name of Landsburgii to a shell, I said jestingly to the friend who told me of it, "Is it possible to sail far down the stream of time in a scallop?" "Yes," was the reply, "the name that is written on Nature will be had in remembrance, when sceptres are broken, and thrones overturned, and dynasties have passed away." The humble name in question is so faintly inscribed, that the rough wave of time will soon totally efface it; but there is a higher and more permanent honour that we should all supremely court,-that our names be written in the book of life; then, when the sun, and the moon, and the stars are darkened, we shall shine with the brightness of the firmament for ever and ever.

I have never seen this Lepralia since the specific name was given to it. Two specimens were found; one was sent by me to Dr. Johnston, and the other lost before he had time to examine and name the one sent. I attempted to 
see it in the British Museum, where Dr. Johnston's collection of zoophytes is deposited, but the day was dark, and the attempt unsuccessful. It is well figured, however, in Dr. Johnston's plate liv. fig. 9, and well described as follows:- "Polypidom forming a thin, white, and closely adherent circular crust of the size of a wafer: the cells rather large, horizontal, continuous, ovate, semi-alternate, with the walls thin, glossy, and hyaline, thickly dotted with perforated granules; the aperture somewhat prominent, oblique, patulous, unarmed, circular, sinuated on the proximal side, and in the centre of this sinus there is usually a small mucro." By a letter from Mr. Peach I learn that he has found it at Peterhead.

\section{Lepralia auriculata, A. II. Hassall.}

Hab. On shells. Trawled off Bray, and found on oystershells, coast of Norfolk, A. H. Hassall; on a valve of Pecten maximus, off Scilly, Mr. M'Andrew.

"Cells coalescent, short, rhomboidal, bounded by a fine and very distinct line; the aperture small, circular, plain, with an arched sinus on the proximal side." (Hassall.)

*** IVall of the cells punctured.

15. Lepralia pertusa, $W$. Thompson.

Hab. On rocks and old shells. On a Lima from the 
Isle of Man, Prof. E. Forbes ; Cornwall, Mr. Peach ; dredged off Sana, Mr. Hyndman.

"Cells ovato-ventricose, punctured, distinct, with a somewhat circular aperture, the margin of which is plain and even." ( $W$. Thompson.) The only specimen I have seen of this, I had from Mr. Busk, Greenwich.

16. Lepralia punctata, $W$. Bean.

Hab. On rocks, and sometimes on shells between tidemarks.

Crust thin, greyish when old; the young cells are whitish, and $I$ have a specimen on an old shell, in which the young white cells are surmounting the old grey crust. It is very common on slaty rock at Saltcoats and at Whiting Bay, Arran. I have never observed denticles on either the upper or the under lip. On some specimens I have, the lips are both thickened, and there is a round tubercle under the inferior lip. In other specimens there is a little sharp loop on each side of the aperture. The tubercles are said to be young ovaries. This pretty species comes very close on some of its neighbours, and it requires considerable powers of discrimination to discern the distinctions.

17. Lepralia annulata, D. L. (Plate XVIII. fig. 68.) Hab. On the fronds of Laminaria saccharina, common 
on the coast of Ayrshire, of Arran, and of Cumbraes. It has been found on shells of Lime dredged off Sana Island, Mr. Hyndman.

When I sent this many years ago to Dr. Johnston, I was considerably gratified by learning from him that it was new to Britain, and corresponded with the description given of Cellipora annulata, by Otho Fabricius, in his 'Fauna Grœnlaudica.' In Greenland it would appear that the cells are generally found in a solitary state. We have not found them so, but we have often seen only four or five together; more commonly, however, they are in a round patch of about a dozen. It is a very pretty species. Otho Fabricius says, "pulcherrima et perfectissima hæc omnium visorum." Each cell is like a little barrel closely hooped, and having transverse rows of perforations betwixt the hoops. There is often a medial line from the top to the bottom of the cell. The aperture gapes, and has a stout rim like an upper and under lip. In many specimens there is a tusk on each side of the mouth, turned up and terminating with a knob; and occasionally there is one, sometimes there are two, smaller teeth on the lower lip. The colour in general is a pale brownish-red. It is at times found in the inside of old shells. 
18. Lepralia figularis, $C . W$. Peach.

Hab. On an old bivalve shell, Cornwall, Peach.

Cells barrel-shaped, flattened on the upper side, which is crossed by small punctures and surrounded by large ones. Thought to be allied to $L$. annulata.

19. Lepralia biforis, $W$. Thompson.

Hab. On Ascidia, Strangford Lough, and on old shells, W. Thompson; on Pecten maximus, dredged at Larne, $\mathrm{R}$. Patterson; on a floated piece of the bark of a tree, coast of Ayrshire, D. L. Mrs. Gatty finds a pretty transparent variety on Ph. rubens, at Sidmouth.

This is a pretty well marked species. The cells are punctured round the sides and near the moutl, leaving the middle part smooth, where above the mouth there is a halfmoon-shaped hole. The mouth sometimes has a spine on each side; Mr. Peach has found it with three spines on the under lip. The capsules are globose, white and smooth.

20. Lepralia Peachit, C. W. Peach.

Hab. On stones and shells, Cornwall, Peach; dredged off Sana Island, Mr. Hyndman; on old shells, coast of Ayrshire, D. L.

The cells are globose, perforated by oblong punctures, 
arranged in a circular manner round the base, but smooth towards the aperture. It varies a good deal, but generally there is a mucro on the upper lip, and five or six short spines on the lower lip. It seems not uncommon.

21. Lepralia pediostoma, A. II. Massall. (Plate XVIII. fig. 67.)

Hab. Dublin Bay and Plymouth Sound, Hassall ; Cornish coast, Peach ; Berwick Bay, rare, Dr. Johnston; Exmouth, Rev. T. Hincks; coast of Ayrshire and of Arran, common, D. L.

This is a handsome and very distinct species, with large cells, the walls of which are either pitted or spotted, the spots being the punctures covered with a thin membrane. It grows in considerable patches. Dr. Johnston mentions that it is sometimes of a light crimson-red, or sometimes of a pure white colour, often with a glossy lustre. It has the glossy lustre with us, but it is never crimson-red, and seldom pure white: it is often light grey, and more frequently a pale lilac.

22. Lepralia verrucosa, $\boldsymbol{W}$. Bean.

Hab. Near Scarborough, rare, Mr. Bean; Dublin Bay, Miss Ball; Cornwall, Mr. Peach.

This is thought by some to bear some resemblance to 
L. pediostoma. I am not so well acquainted with it as with L. pediostoma, but I have specimens of it from Dr. Greville and Mrs. Gatty, and I can see no approximation except in the colour, and perhaps the size. L. pediostoma is stout and not easily injured; L. verrucosa is thin and very friable. The former is punctured all over; the latter is areolated towards the base of the cells: the aperture of the former has a plain rim; the latter has a strong mucro on the upper lip.

23. Lepralia reticulata, J. Macgillivray.

Hab. On bivalve shells, deep water, rare.

A fine specimen of this, the only one I have seen, I had the honour of receiving from Lady Emma Campbell, of Argyle. It is on a beautiful Pecten striatus, dredged in Loch Fine.

Nearly allied to Lepralia variolosa.

24. Lepralia variolosa.

Hab. On stones, and bivalve shells.

This is spoken of by Mr. Peach as Proteus-like. The two varieties in Dr. Johnston's plate lv. figs. 8 and 9, might almost be regarded as distinct species. It is very various in colouring also. It is described as yellowish, or dull grevish-white; now I have a specimen of it from Dr. 
Greville from Orkney, and I have repeatedly got specimens of it on the coast of Ayrshire and of Arran, covering a considerable space of bivalve shells with cells of the purest white. The cells are oblong, depressed, the space betwixt them punctured. The aperture is sometimes with a sinus on the upper lip, sometimes with a denticle; at times with a plain margin, and at other times with tro spines on the under lip.

25. Lepralia fenestralis, $R$. Q. Couch.

Hab. On stones, Cornwall, R. Q. Couch.

Cells urceolate, with longitudinal and transverse lines, giving a net-like or window-like appearance, covered with a transparent membrane, which Mr. Couch says is best seen when dry.

26. Lepralia nitida, Dr. Fleming.

Hab. On shells and Laminarice, rare, Dr. Fleming; Isle of Man, Prof. E. Forbes; Scarborough, rare, Mr. Bean; Devonshire, common, Rev. T. Hincks; Cornwall, Mr. Peach; Strangford Lough, Mr. W. Thompson; Berwick Bay, Dr. Johnston; coast of Ayrshire, coast of Devon, coast of Ross-shire, D. L.

This is perhaps the greatest beauty of this beautiful family. It even surpasses $L$. annulata, so much and so 
deservedly admired by O. Fabricius. Mr. Hassall's comparison, though, except to an anatomist, not a pleasing one, gives a good idea of it. It is like "a miniature human thorax ; the cross-pieces representing the ribs, and the broad band into which these are inserted being analogous to a sternum." We must suppose it the thorax of a pretty little fairy, for notwithstanding its skeleton-like aspect, it is very beautiful. It is rare in Scotland. The finest specimen I have seen I got on the shore opposite to Fort George, Inverness-shire. It was almost equalled by specimens I got from Miss Cutler, at Budleigh Salterton, the whole fabric of which had a metallic appearance; the tiny ribs seemed made of steel. There are several varieties of it, for the aperture is sometimes unarmed, and at other times with a spine at each side; those I got at Budleigh Salterton had five long spines on the under lip. It is common on Eschara foliacea in Devonshire. "When living, it is either a yellowish flesh-colour, or intermediate to a silvery white." (Couch.)

26*. Lepralia meiolontha, 'Busk. (Plate XVIII. fig. 70.)

This cannot but be regarded as a remarkably beautiful species, seeing that it was for some time considered as what 
we may call an improved varicty of that little gem, $L$. nitida. It was discovered by Mr. Busk on oyster-shells from the south of England, and on shells from the Thames, sent to him by Lieutenant Thomas. It was also detected by Mrs. Gatty on oyster-shells sent to her from the south of England; and on her specimens some of its distinguishing characteristics were first observed. After strict and deliberate examination, it has been found to be quite entitled to rank as a distinct species, to which the very appropriate name, melolontha, has been assigned, because it has a tail turned up very like a cockchafer's. It has a hyaline crust, and two turned-up horns on the under lip. I have it from Mrs. Gatty, to whose felicitous pencil I am indebted for all the figures of the Lepralia, Plate XVIII., except fig. 71, an exquisite representation of $L$. Gattya, by Dr. Greville, of Edinburgh. The following description of $L$. melolontha I owe to the kindness of Mrs. Gatty.

"This is the variety of $L$. nitida mentioned by Dr. Johnston as 'branched in a fine dendritic manner, like Alecto dilatans.' It differs from $L$. nitida in the cells being immersed in a delicate transparent crust; so that, in some cases, there is a considerable intervening space between each cell. A still more remarkable feature, and the one 
from which its name has been taken, is a thick strong spine, which turns up, nearly at right angles, from the lower end of the cells. Two equally thick and strong spines stand up in the same position, one on each side of the mouth; the two mouth-spines and tail not being perfectly upright, but inclining slightly towards each other. The resemblance of many of the cells to a cockchafer or tailed-beetle is very striking. I have only found $L$. melolontha on the flat shells of native oysters, and usually near the joint end, in some little dip or hollow, where the polype perhaps hoped to have his house and himself secure from injury. But if so, we must admit that he is a very bad judge of such matters, for the flatness of his favourite shell exposes him to so many rubs and injuries that it is hardly possible to find a specimen in which the tail and mouthspines are perfect; in so many cases they have been broken off, leaving an aperture in their place. These accideuts have perhaps been the cause of the peculiarity of this species not having been sooner noticed; for, deprived of the mouth-spines and tail, it is difficult to discover any difference between $L$. melolontha and $L$. nitida, except the fact of $L$. melolontha growing in a branclied figure, instead of in alternate rows, as is the usual Lepralia fashion." 


\section{Lepralia innomitata, $C . W$. Peach.}

Hab. On stones and shells, coast of Cornwall, Peach; dredged off Sana Island, Mr. Hyndman.

Though this pretty little distinct species is found near us, I have not falleu in with it on the coast of Ayrshire; but I have a specimen of it before me, from Mrs. Gatty. The cells are white, ovate, and sometimes almost orbicular; and when the ribs diverge from a central umbo, it is like a Pecten in miniature. "The margin is surrounded by numerous long and slender bristles, which are very commonly destroyed." (Couch.)

2S. Lepralia semiluxaris, A. H. Hassall.

Hab. Dublin Bay and coast of Norfolk, Mr. Hassall.

The cells are perforated; the aperture semi-lunar; often with an operculum, and at times with a short spine on each side of the mouth.

**** IVall of the cell roughened.

29. Jepralia unicorvis.

Hab. On rocks, and on the roots of $L$. digitata.

This is very common on the coast of Ayrshire, on the roots of Laminaria digitata. The cells are disposed in rows, rough and scaly, with a constricted aperture. Colour reddish and sometimes white. 
$\therefore) \div$

$\because \therefore 2 \therefore$

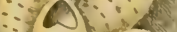

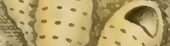

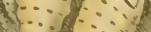

$63^{\circ}=20 \%$
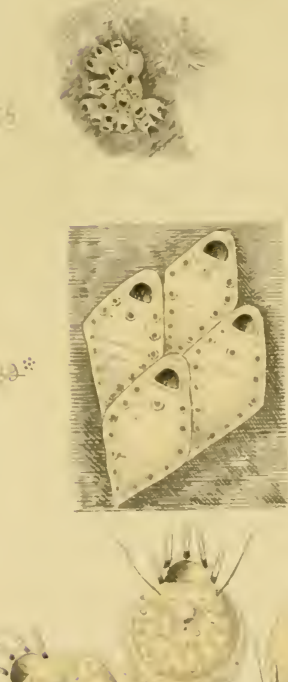

$$
2.4
$$$$
\text { - }=
$$

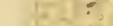

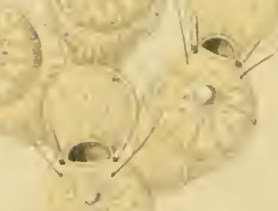

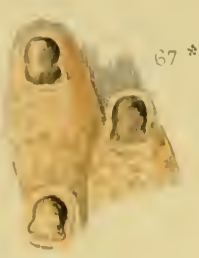
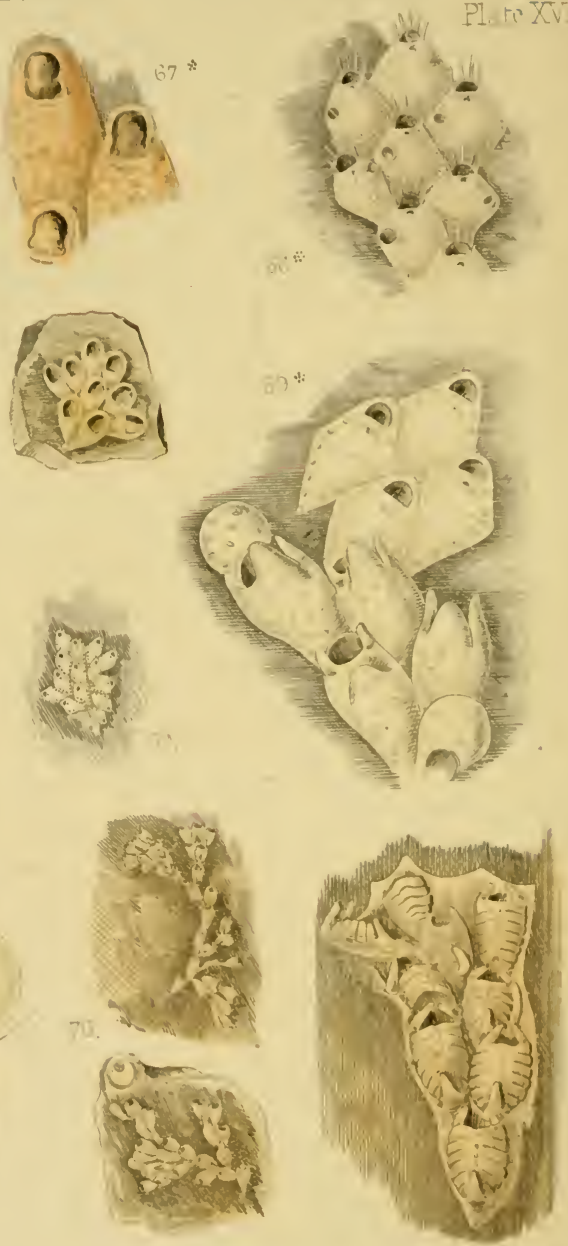

$70 \div$ 
30. Lepralia Ballit.

Hab. On bivalve shells, island of Sana, Mr. Hyndman; coast of Cornwall, Mr. Peach.

This is dedicated to Robert Ball, Esq., of Dublin, an eminent naturalist. The cells are short and raised, thick, and rough with granules; the aperture wide, with a mucro above the upper lip, and with two ear-like open loops at the side. Capsules in front, rounded, granulous. It is now thought to be a variety of $L$. coccinea.

31. Lepralia coccinea, Dr. Fleming.

Hab. On the under side of stones, Dr. Fleming; on Nullipora polymorpha, Isle of Man, Prof. E. Forbes ; Cornwall, Mr. Peach; Isle of Wight, Mr. Thompson; near-St. Andrew's, Prof. Read; Falmouth, Dr. Cocks; dredged off the Tees, Lieut. Thomas, R.N.; on roots of Laminarin. digitata, Saltcoats, D. L.

"Cells sub-cylindrical, adjacent, in divergingly bifid rows; mouth wide, a single blunt tooth on the outer margin, and two or three spines on the 'immer." It is pretty common on the coast of Ayrshire.

32. Lepralia ciliata. (Plate XVIII. fig. 66.)

Hab. Parasitical on seaweedis, rocks, and shells; common. This is one of the most common of our Lepratias, and 
pretty easily distinguished, though it assumes some variety of forms. The cells are ovato-globose, frosted; the aperture sub-circular, with from three to seven spines, those in the middle being long, and those at the sides short. There are no spines on the upper lip, but there is a knob above it. The L. insignis of Hassall, besides the spines on the upper lip, has a single spine arising from the side. I remember that he was pleased when I sent him specimens of it from our Ayrshire coast, where it is pretty common. It is smaller and neater, but Dr. Johnston thinks it is only a variety of the normal state.

33. Lepralia spinifera, A. H. Hassall.

Hab. Rather abundant on stones and shells, in Dublin Bay, A. H. Hassall.

This differs from $L$. ciliata scarcely in anything except that it has a sinus in the upper lip.

34. Lepralia trispixosa, Dr. Jolinston.

Hab. On shells, Berwick Bay, rare, Dr. Johnston; coast of Cornwall, Mr. Peach; near Aberdeen, on roots of Laminuria cligitata, J. Macgillivray.

Crust often silvery white, with minute yellow dots; cells rough ; aperture a little cleft above, having three stout long spines on the under lip. 


\section{Lepralia immersa, Dr. Johnston.}

Hab. On shells and stones from deep water.

The crust is rough, the aperture small, with a blunt tooth on the upper lip; the surface minutely granular. Dr. Johnston says it differs from L. ciliata in having a more solid texture; in forming larger patches; in the much less distinctness of the cells; in the aperture having no rim, but a slight projection in the upper margin; and in there being no knob behind it. It is not uncommon on the west coast. I have specimens of it, from Tiree, on Pinna ingens.

36. Lepralia violacea, Professor Forbes.

Hab. On Nullipores, from the Isle of Man, E. Forbes; coast of Cornwall, Mr. Peach; Dr. Greville.

"This species is nearly allied to the latter, and the most distinguishing characteristic may be the purple colour of the crust, which is quite peculiar to it."

37. Lepralia bispinosa.

Hab. On Modiola vulgaris, Berwick Bay, Dr. Johnston.

Dr. Johnston states that this species bears a very close resemblance to Cellipora pumicosa. By his figure of it however (plate lvii. fig. 10), it seems sufficiently distinguished from it by the very long spines which originate from the angles of the lower lip. 
35. Lepralia Gatryæ, Busk. (Plate XVIII. fig. 71.)

Hab. Discovered by Mrs. Gatty, of Ecclesfield, on Phyllojihora rubens, from Sidmouth and Jersey.

The following description is from the pen of Mrs. Gatty. "A delicate and beautiful Lepralia, of transpareut texture, found hitherto only on Phyllophora rubens; and being usually surrounded by patches of other varieties of its race of larger size, it is very apt to be overlooked. Its very minute size is, however, an almost sure guide by which to find it; and when once seen through a tolerably good lens, it can never be mistaken for any of its relatives. The commonest observer, who can see it at all, will see that the centre of each cell is ornamented with a rich pattern, whereas other Lepralice are either dotted all over the cell, or round the sides, leaving the centre plain, or across the cell in lines. The pattern of L. Gattya, therefore, thrown as it is on the middle of the cell, is a very characteristic feature. There are two other characters which separate it entirely from other species; but these require a stronger glass to detect them. At the foot of each of the five spines that surround the mouth or aperture, there is a black ring. (See the Plate.) [This is supposed by Mr. Busk to be a flexible joint, similar to that of Crisia denticulata.] And below 
the mouth there is, on each side, a single fine spine, which may be compared, perhaps, to a cat's whisker. The pattern of the ornamented centre will be best understood by a reference to the Plate. In the middle of all there is a knob or projection (more or less obvious in different individuals), and round this 'umbo-like projection' there is a circle of small dots or punctures. From this circle emanate rays, or raised lines, between each of which is to be found a dot or puncture, larger in size than those of the other circle. These rays and stars, as they may be called, are alternate, and so form a circle outside the circle that surrounds the umbo. Dr. Greville discovered that the pear-shaped termination of each cell is delicately fluted, as represented in the Plate; but this character cannot be considered a universal guide, as the pear-shaped termination to the cell is wanting in many specimens, perhaps from the overcrowding of the cells.

The species has been found, during two successive winters, at Sidmouth (1851 and 1852), and is to be met with also in Jersey.

Genus XIV. MEMBRANIPORA, Blainville.

Gen. Char. Polypidom incrusting, membrano-calcareous, 
spreading irregularly, formed of a single layer of alternating approximated cells; cells oval, horizontal, membranous, the aperture patulous, with a hard calcareous rim.-Johnston.

1. Membranipora pilosa, Ellis.

Hab. On seaweeds, abundant, and also on shells.

This zoophyte is often met with in greater abundance than many would wish, as it completely covers, and in a manner conceals, the objects on which it grows. Yet, though when it is of a dirty white colour, smothering some delicate alga, we might wish that it were away, when the attention is turned to it in some of its finer aspects it is truly beautiful. When it is of a fine fawn-colour, clothing a little branching seaweed, it is quite lovely; and not less so when it spreads itself freely on some broad-leaved seaweed, as it often does, either irregularly or in a stellated form. It has then a silvery appearance, and many, when for the first time they examine it with a lens, and see its sharply-toothed and granulated cells, are so struck with its beauty that they conclude that this exquisite production must be very rare. Behind the mouth of each cell there is a very long tubular bristle.

The polypes of this species are furnished with a singular organ, described by Dr. Farre and by the Rev. T. Hincks. 
It is oblong, placed between the base of two of the arms, and attached to the tentacular ring. Round the opening at the top there is a play of cilia, and it is lined with cilia. Mr. Hincks had long made this organ the subject of investigation, and at length he was rewarded by the following discoveries. "Specimens of the zoophyte were procured in spring, in which the cercaria of Dr. Farre-filamentous bodies which are found swimming in the visceral cavity in many species of Bryozoa-were present in great abundance. In one of these polypes I observed a mass of these cercarice wriggling upward from the lower part of the visceral cavity; and each filament, when it reached the base of the organ before referred to, was drawn into it and carried through it by the action of the cilia lining the interior, and then ejected and borne off by the tentacular currents. This expulsion went on for three or four minutes, during which time the filaments were streaming up incessantly from below. After a while a single filament only made its appearance occasionally, and at last none were to be seen."

Dr. Farre having observed the cercaria in Alcyonium, "drifting rapidly to the upper part of the visceral cavity," adds, "it would appear from this that there is some external communication with the cavity of the body." Mr. Hincks 
states, "My observations show that this communication is through the intertentacular organ, and that whatever purpose it may subserve besides, in the economy of the Bryozoon, it is at certain seasons the channel through which cercarice are ejected from the visceral cavity.-The connection proved to exist between the ciliated organ and the cercaria-which must be regarded as spermatozoic bodiesmay be accepted as conclusive evidence that it is subservient in some way to the function of generation."

Since I wrote the above, I put into a tumbler of seawater a small fragment of Odonthalia dentata, on which I saw there were zoophytes. On applying a pocket-lens, I observed a very perfect specimen of the small creeping variety of Sertularia rugosa, and I was much struck with the sculpture of the large resicles, resembling the finest cut crystal vases. The pretty cells were closely set in alternate order, and from several of them the purely white polypes were fully expanded. Then I observed a beautiful little specimen of Coryne pusilla, var. muscoides, with many live polypes, intermingled with oval vesicles. My attention was then caught by Membranipora pilosa, a very common object, but even more interesting than either of the others, for there was more life about it. The little 
white polypes were popping out of their cells, and anon with the quickness of lightning darting back into them again. But I observed, what was quite a new sight to me, one of the polypes which had broken loose from its cell, and was voyaging through what must have seemed to it a vast field of waters. To the naked eye it was almost invisible, but when magnified by the lens it was like a beautiful little hand-bell, the bell, which was bowl-shaped, being formed by about twenty tentacula, and the body, or part of the body, constituting the handle. Beautiful as it was, I could not help regarding it with pity. I fear it was not a voyage of pleasure. It was bounding about, but its efforts seemed convulsive. It closed its little arms, as if it had been clasping them in anguish, and then by a sudden jerk threw them out again. Perhaps it had been torn by violence from its home, and knew not the way back to it, so that its wanderings may have been its misfortune and not its fault. I soon lost sight of it, and it may have perished. Less to be pitied, however, than many thoughtless youths, who intentionally go astray, and who, being launched on a dangerous sea without helm or compass or chart, are driven about and tossed, and terminate their guilty career amidst blackness, and darkness, and tempest. 
2. Membranipora membranacea, Dr. Fleming.

Hab. "Common, especially on stones near low-water mark," Dr. Fleming. " I have never seen it on seaweeds," Dr. Johnston. On the coast of Ayrshire it is common on the inside surface of old specimens of Buccinum undatum; I have it also on the outside of Patella carulea, D. L.

This is the Flustra unicomis of Dr. Fleming; the Flustra tuberculata of Dr. Johnston's first edition. It spreads to a considerable extent as a thin gauze-like crust of a whitish colour. The cells have a large ovate aperture, and above it there is a stout hollow conical process.

The workmanship is very delicate, and $\mathrm{He}$ who made the artificer endowed it with instinctive prudence to choose a sheltered position for its domicile. It spreads itself on the smooth pure white inner surface of a newly deserted Buccinum, and though the shell should be tumbled about with the storm, the inside colony are perfectly safe. But where is the prudence, it may be said, in building its city on the very outside summit of Patella carulea? Even here its prudence is not at fault, for the Patella chooses for itself one of the suuggest possible residences. It hollows out a cave in which it may ensconce itself in the very centre of the roots of Laminaria digitata, and in this munition the Membrani- 
pora is as safe on the outside of the Patella as it could possibly be in the inside of the Buccinum, and this while the inmate of the cærulean limpet is yet alive.

\section{FAMILY ESCHARID王.}

"I stood upon a smooth and sandy shore,-

'Twas one of Autumn's bright and sunny days,-

The sea was clear as crystal-hush'd its roar, And distant mountains soften'd by the haze;

Green were the waters, and the sky deep blue

Reflected in them form'd a lovely hue:

Huge porpoises were rolling o'er and o'er,

And fishermen were busy on the shore,

Mending their nets to cast into the deep,

That they of ocean's stores their share might reap;

While dove-like mews were hovering o'er the sea,

Dipping their wings and feet luxuriously." -Miss S. Beever.

Several species of the Escharide have certain singular organs attached to the cells, and called the avicularium, or bird's-head, in consequence of their shape. Dr. Johnston has recorded some interesting remarks made on them in foreign species by Mr. Darwin; and I am happy that I am permitted to copy the following observation made on them in our native species, by the Rev. T. Hincks, of Exeter. "The 'bird's-head processes,' with which some of the 
species of Bryozoa are furnished, have engaged the careful attention of naturalists, and their form and movements have been accurately described. But though we have many conjectures as to their precise function, and relation to the economy of the animal, few facts have as yet been recorded which throw light on the uses of this curious portion of structure. Such being the case, the following observations may have some interest.

"The organ to which I refer bears a striking resemblance to a miniature bird's head, and is mounted on a short pedicle, furnished in most cases with a basal joint, by means of which it can be swayed backward and forward. These 'processes' are distributed in great numbers over the polypidom, one being generally placed on each cell.

"The beaks are continually gaping and closing with much vehemence; and the entire organ is frequently swung to and fro. The movements, as it has often been noted, are quite independent of the polypes; and Mr. Darwin has well remarked, that in their functions these bodies 'are related rather to the axis than to any of the polype.'

"There is something very comical in the energy and earnestness with which these tiny jaws open and close, and throw themselves about, no cause being apparent, in general, 
for the outrageous gapings and eccentric jerks in which they indulge. They occur on several British species, as, for example, Flustra avicularis and Cellularia avicularis.

"While watching, on one occasion, a piece of the latter zoophyte through the microscope, a worm passed over it and among its branches. It was almost immediately firmly grasped by one of the avicularia, and forcibly detained. In a short time one end of it was seized by another, from which, however, by its violent contortions, it extricated itself, but not without injury. The first assailant, meanwhile, kept fast hold, and soon two others caught the unfortunate at different points of the body. Thus it was held securely pinioned; and all its efforts to disengage itself, which were most vigorous, proved unavailing. The aricularia grasped the body of their victim most viciously, and nearly divided it. When I last observed the contest, the worm seemed exhausted by its struggles, and scarcely stirred; the beaks remaining firm and motionless. These strange police-officers were very systematic in their operations, and, in capturing the intruder, seemed to be dis. charging a very ordinary function.

"There can be little doubt, I think, that it is the office of these organs to defend the Bryozoon from its enemies. 
The beaks are well placed for such a purpose, and their incessant gaping and swinging must enable them readily to detect the presence of trespassers. The avicularia, then, must be regarded as part of the machinery of the axis, charged with the special office of keeping the polypidom free from extraneous matters. An analogous contrivance occurs on others of the Bryozoa, consisting of large bristles attached to the cells by a joint, upon which they move backward and forward with considerable force. These clear away obnoxious matter from the neighbourhood of the cell, and keep the surface of the polypidom clean. I can confirm, from personal observation, the remarks which some authors have made respecting the force with which the movements of these hair-like appendages are exccuted."

How interesting and instructive are these observations! They show the kind care of the great Creator over the minutest of His creatures. And will He not care for the children of His own family-for His ransomed? Yea, verily; He who has sent His Son to save them, will give His angels charge over them; for it is written, "Are they not all ministering spirits, sent forth to minister for them who shall be heirs of salvation?" 


\section{Genus XV. CELLUIARIA, Pallas.}

Gen. Char. Polypidom calcareous or membrano-calcareous, confervoid, divided dichotomously; the divisions narrow, composed of two or three alternating series of oblong contiguous cells on a single plane; the apertures lateral, oblique, and facing one way. Polypes ascidian, with usually fourteen tentacula; no gizzard.-Jolenston.

* Aperture of the cell terminal.

1. Cellularia ciliata, Ellis. (Plate XVII. fig. 62.)

Hab. On corallines, roots, and also branches of Algæ. Salcombe, Rev. T. Hincks; Irish coast, sparingly, W. Thompson; Peterhead, C. W. Peach; coast of Ayrshire, rare, D. L. Dr. Fleming says it is common; from which I conclude that it is much oftener met with on the northem and eastern shores of Scotland than on the western. I have had good specimens of it from Miss Allardyce, of Cromarty; a very large specimen from Miss S. Beever, of Coniston, but I believe it was from a friend (Miss Hislop) in the Isle of Man; and I have often got it in little tufts on scaweeds, sent me in a rough state from the south of England.

The little tufts are from half an inch to nearly an inch in height, delicate, of pellucid whiteness, and dichotomously branched. The cells crown the top of the branches; the 
wide apertures are fringed on the upper edge with four or five long ealcareous spines, which are easily broken off when dry, and the mouth is often covered with a pearly operculum. It is in all states beautiful; but when a lens is applied to it in this pearl-operculated form, it is one of the finest objects of a minute nature that can anywhere be seen. What human hand would not hang down in despair, if required to imitate it; and yet the great UnseEN teaches an almost invisible worm thus elegantly to fashion it. $\mathrm{We}$ have ten fingers, and they often work wonders. Professor Edward Forbes states that this little Ascidian polype has from twelve to sixteen, to which we give the name of tentacula.

2. Cellularia ternata, Dr. David Skene.

Hab. Sent from Aberdeen, by Dr. D. Skene, to Ellis; Dr. Fleming's were from Zetland; mine were from Lady Keith Murray, Stonehaven, and from Mr. Bean, of Scarborough, at which latter place it is not rare on corallines, and sometimes attached to shells. Peterhead, abundant, Mr. Peach.

It is about an inch in height, branching dichotomously; the cells enlarge gradually in breadth towards the top, and are armed above with two or three short spines. It takes 
not its specific name from the number of the spines, but from having three cells betwixt every two joints.

** Aperture superior, subterminal, oval.

3. Cellularia scruposa, Creeping Stony Coralline, Ellis.

Hab. On the roots of Laminaria digitata, and on corallines and seaweeds. Peterhead, not uncommon, Mr. Peach. It is common in the Firth of Forth, and in the north of Scotland, but we have very seldom met with it in the west. Mr. Robert Gray has found it in abundance to the east of Dunbar. Where it is found at the roots of seaweeds, it often covers an inch square, creeping along the surface, and attaching itself by tubulous root-like fibres; the cells are oval; each cell has two appendages, the one in the form of pincers, and the other is furnished with a long moveable bristle.

4. Cellularia reptans, Ellis.

Hab. On corallines, seaweeds, etc.; common.

This is pretty like the preceding, but the tufts are larger. The branches are dichotomous; the cells have an oblique opening, armed with four or sometimes five short spines. The colour is lighter than that of the preceding; with us it is light grey, and not unfrequently tinged with red. It is very abundant, on the coast of Ayrshire, on Halidrys sili- 
quosa. It is attached by tubulous fibrous roots, proceeding from various parts of the polypidom; and Ellis mentions that they are often hooked, to give it a firmer hold. The dichotomous branches are jointed at their base, as shown by Ellis (plate xx. fig. 4). What skill and kindness in all His works! "The ramifications are connected by some short pliant tululi, which serve as so many hinges to the branches to play to and fro freely, and comply with the violent motions of the sea. These hinges seem to consist of two short tubes, one to each row of cells, and are so firmly united to each branch that they seem insensibly to pass into the cells of each." (Ellis.) Ovarian capsules not common.

5. Cellularia IIookeri, Sir $I V$. J. Hooker.

Hab. Found by Sir William Hooker at Torquay; and by Prof. E. Forbes in Zetland.

This beautiful little coralline is of great rarity. It is thus described by Dr. Fleming:-" Height upwards of an inch, dichotomously branched; branches straight, stiff, brittle, divaricate; the cells are protuberant dorsally, and their rounded top is nearly free, projecting laterally, giving the edge a remarkably jagged outline, and the pearly ovaria are rounded." In addition, Dr. Johnston states that near 


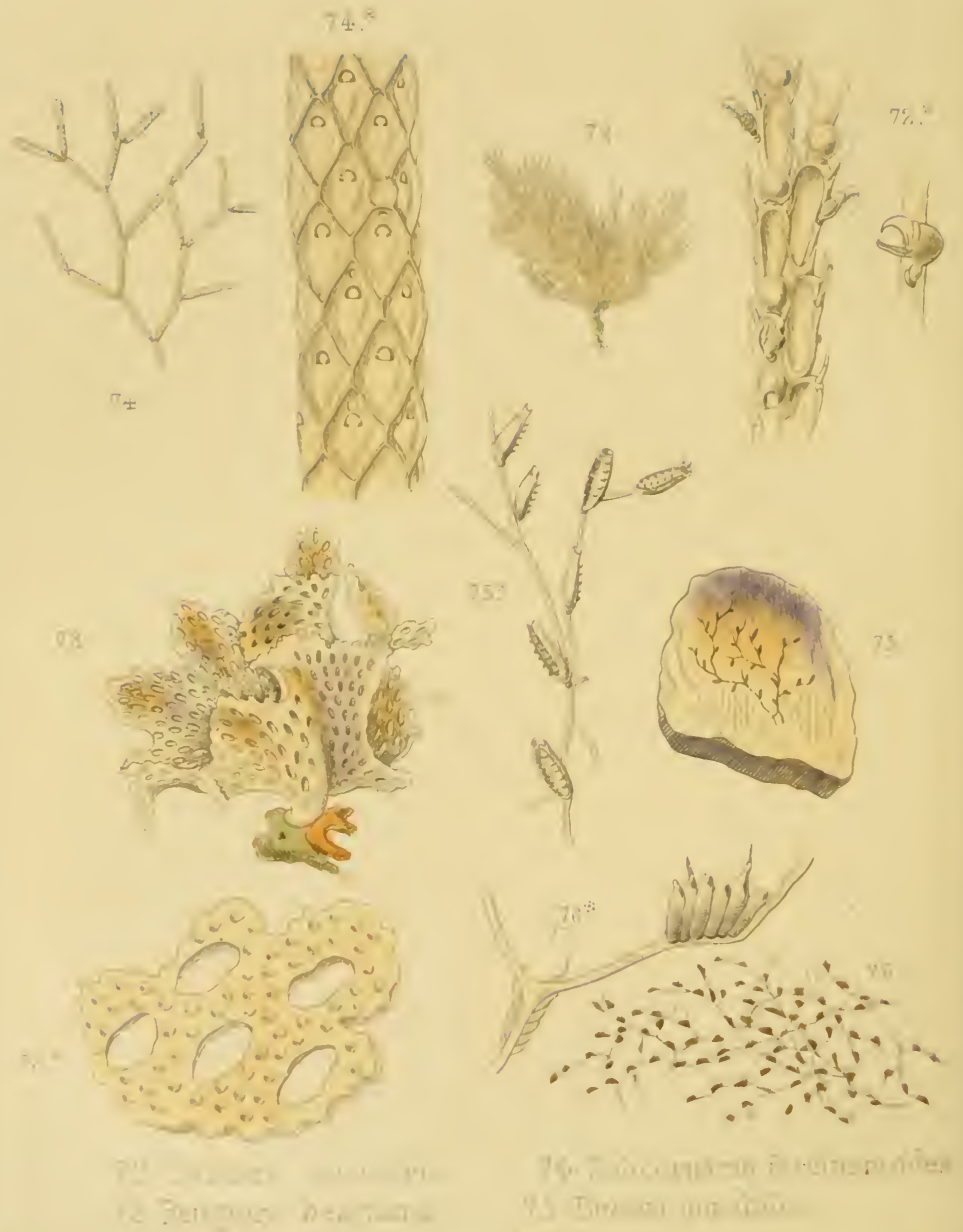


the base of some of the cells there arises a long setaceous bristle, that bends over the upper surface of the polypidom, and it is moveable. We doubt not that this formidable lash is to keep off intruders, and to sweep them array when they have made encroachments.

\section{*** Apertures superior and very large.}

6. Cellularia avicularia, Bird's-head Coralline, Ellis. (Plate XIX. fig. 72.)

Hab. On corallines in deep water. Salcombe, common, Rev. T. Hincks; Peterhead, Mr. Peach.

The polypidom is erect, bushy, greyish-white. The cells have a spine at each of the upper angles, and the aperture is generally covered with a round pearly operculum. "On the outside of each cell we discover the appearance of a bird's head, with a crooked beak, opening very wide." (Ellis.) It is distinguished from Flustra aricularis by having two conical spines at the angles, whereas it ( $F$. avicularis) has four, which also differ in appearance. The colour, likewise, is fainter when dried. I have it from Mr. Tumanowicz, Hastings.

**** Apertures lateral and very large.

7. Cellularia neritina, Miss Blaclibume.

Hab. "Miss Blackburne, Cheshire," Dr. Fleming; Scar- 
borough, very rare, Mr. Bean ; Tynemouth, Miss E. Forster; Copinstra, Lieut. Thomas, R.N.

Several inches in height; cells oblong; aperture large and oval; capsules pearly and formed like a young Nerita, whence the specific name.

S. Cellularia plumosa, Doody.

Hab. Not uncommon beyond low-water mark, Fleming; Salcombe, Rev. T. Hincks; Hastings, M. Tumanowicz; Firth of Forth, D. L., jun.; Lochryan, oyster-shells, D. L.

Two inches high, in habit a little like Sertularia argentea, but more tufted, and it is often of a pink colour, with pearly operculums.

9. Cellolaria Peacini, Busk.

Hab. Boddom, Buchanness; Peterhead, Tynemouth, Copinstra, Lieut. Thomas, R.N.

The account of this new species I take by kind permission from Mr. Busk's account of it in the 'Annals of Natural History.' Mr. Peach, by whom it was first observed to be distinct from $C$. neritina, remarks that the species is bushy, erect, attached to stoncs, old shells, and to other zoophytes, from deep water, brought up by fishermen's lines off Peterhead.- "It is white, and of a delicate shining aspect when dry ; the branches long, slender, and straggling. 
The inferior end of the cell as seen behind much contracted; the mouth regularly oval, and surrounded with a somewhat thickened margin, beset with minute verrucosities. There is a row of from three to five small openings towards the outer border of the cell on the back, and the upper and outer angle in front supports a minute upright spine, which is, however, not unfrequently wholly wanting. There are no moveable appendages. The ovarian cells are rounded and affixed above the cell to which they belong, and immediately behind the upper margin of the month, which in that case is slightly depressed. The external surface is marked by lines crossing each other obliquely, and giving it a tessellated aspect. The mouth of the cell is filled up by a delicate transparent membrane, in the upper part of which is situated the crescentic orifice, protected below by a projecting, and probably moveable labium, as in others of this class." (Busk.)

\section{Genus SCRUPOCELLARIA.}

1. Scrupocellaria scrupea, Busk.

Hab. Dredged near Dartmouth by Prof. E. Forbes, and by Mr. M`Andrew in the Mediterranean. 
I insert also in this place, by the same kind permission, Mr. Busk's account of this zoopliyte, new to our British Fauna.

"In stating the form of the cells in this genus, it is more convenient usually to refer to the back view of them, as I have doue in this case.

"In habit this species bears so close a resemblance to S. scruposa that to the naked eye there is very little difference between them. The branches are a little broader, and perhaps more regularly and more closely disposed. The cells are wider in proportion to their length than in that species, and their sides, especially the upper one, more square and straight. The principal difference in the form of the cell consists in the existence in $S$. scrupea of a rather deep depression or sinus on the back of the cell, and towards the outer margin, in which sinus is lodged the vilraculum*. This organ is placed considerably more behind the cell than it is in S. scruposa, and differs somewhat in shape from the same organ in that species. It is wider, flatter, and, as it were, of a spatulate form. The avicularium occupies the same position, or nearly so, as in that species, or perhaps is

* Mr. Busk employs this term to signify the organ furnished with a moveable or vibratile seta, as distinguished from the prehensile avicularia. 
also placed a little more posteriorly. An important difference, however, between these very similar species consists in the reniform pedunculate operculum, which projects in front of the mouth of the cell. Although this organ exists in a great variety of form in many species of Cellulariacle, and is particularly well developed in the common $C$. reptans, I am not aware that it has hitherto received the attention it would seem to deserve in the distinction of species. This process does not arise from the edge of the cell, but from the wall of the cell a little beyond the margin, and it usually appears to be tubular at its origin. It assumes various forms, some very fantastic, and increases in size as the cell becomes older, so that in the older cells at the bottom of the branches it almost entirely covers the mouth."

\section{Genus XVI. FLUSTRA, Sea-Mats, Linnaus.}

Gen. Char. Polypidom plant-like, membranous, frondose or crustaceous, formed of cells arranged quincuncially in several series, and in one or two layers: cells in juxtaposition, more or less quadrangular, flat, with distinct border: the aperture transversc, semi-lunar, valvular, subterminal.-Dr. Johnston. 


\section{* Foliaceous, with cells on both sides.}

1. Flustra foliacea, Broad-leaved Horn-wrack. (Plate XVII. fig. 63.)

Hab. On hard ground, in a few fathoms water.

It is several inches in height and breadth. We have never found it on the Ayrshire coast except in fragments evidently drifted. I have got it in great abundance betwixt Leith and Portobello; I have it from Mr. A. Tudor, Bootle; from Miss M'Leish and Misses Steel in abundance from the Dee below Chester; from Rev. Mr. Urquhart, Lochryan. I have dredged it sparingly and small in Lamlash Bay, Arran. What I got there, as well as what I got in the Firth of Forth, had, when fresh, a very agreeable flavour, like bergamot, or rather like Verbena triphylla. This pleasant flavour is mentioned by several; compared by one to that of the orange, by another to that of violets, by a third to the mixed odour of roses and geraniums; so that it is probable that it differs in different places, for Ellis ascribes to it an unpleasant fishy smell. It spreads out in a palmated fan-like form. The segments of the frond differ much in size in different specimens, some being narrow, and others more than an inch in breadth, though this is rare. By some it is greatly admired. Hooker says, "For curiosity 
FLUSTRA.

and beauty, I have not, among all the plants or vegetables I have yet observed, seen any one comparable to this seaweed." And yet our Newhaven fishermen speak of this and many other zoophytes as sea-caff, i.e. sea-chaff, either as worthless, or as easily, when dry, driven about by the wind. Nevertheless it is, to those who attentively consider it, an admirable piece of workmanship, as Ray and other intelligent naturalists say, vying in its texture with a web of silk or of fine linen. Its name is from a Saxon word, flustrian, to weave; and He alone who gathered together the waters of the sea could teach these marine manufacturers to construct amidst its waves such elegant tabernacles.

2. Flustra chartacea, Paper Sea-Mat.

Hab. Coast of Sussex, Ellis; Brighton, Lister; Plymouth, Rev. T. Hincks; Dublin Bay, Professor Allman; south of Ireland, Mr. W. Thompson. So far as I know, this has never been found in Scotland, but I have it from Mr. Tumanowicz, Mr. Wigham, and Miss S. Beever, from Hastings, where it seems to abound; also from Mr. Pike, from Brighton.

The cells are an oblong figure, the apertures protected by a helmet-like operculum. It is of smaller size and of more delicate texture than the preceding; of a light straw- 
colour, though occasionally tinted with pink. It is scarcely two inches in height; and it is thin and glistening.

3. Flustra truncata, Narrow-leaved Horn-wrack. (Plate XVII. fig. 64.)

Hab. Very common on many of the shores of Scotland, as well as the north of England, but not found in the south of England. It is common in Belfast Bay. Mr. W. Thompson, Peterhead; abundant and very fine, Mr. Peach. It is found in great abundance betwixt Leith and Portobello. The finest specimens I have seen were gathered by me at the Black Rocks, Leith, at low-water, glistening, when dried, as if varnished. We have found it also at Dirleton, opposite to the Bass Rock. But we have never fallen in with it on the coast of Ayrshire, Arran, or Cumbries.

This differs considerably from both the preceding species. It is much larger than $F$. chartacea, being, at times, fully four inches in height and three in breadth; it is divided into a greater number of segments than $F$. foliacea, and they are narrower and truncated. Leaflets often spring from the edges of the segments. The cells are linear-oblong, and have often a black dot in the centre, which is probably the remains of the dead polype. In the specimens gathered by me at the Black Rocks, Leith, the younger 
FLUSTRA.

portions of the segments were of a pinkish colour, from the cell being filled with living polypes. This species does not appear to have any of the pleasant flavour which characterizes $F$. foliacea.

$$
\text { ** IVith cells on one side only. }
$$

\section{Flustra carbasea, Dr. Skiene.}

Hab. Aberdeen, Skene; Leith, Dr. Coldstream; coast of Durham, J. Hogg; coast of Berwickshire, Dr. Johnston; Bootle, rare, Mr. Tudor; Dublin Bay, rare, Mr. M'Calla; Stonchaven, Lady Keith Murray; on the fishermen's nets at Newhaven, in some abundance, D. L., jun.; Peterhead, rare, Mr. Peach.

It is very easy to distinguish this from any of the preceding species, from having the cells confined to one side. The substance is thin, the colour brownish, and the surface glossy. It has no tufted tubular roots; the segments expand, and are rounded at the top. It is about two inches in height, and, in proportion to its height, broader than either $F$. foliacea or $F$. truncata. Even on the Leith shore it is comparatively of less frequent occurrence. When I told my lamented friend, the late Dr. Patrick Neill, that I had got great abundance of $F$. foliacea and $F$. truncata at Seafield_"But did you get carbasea?" said he. "For 
that you must examine the fishermen's nets and boats at Newhaven." Dr. Grant has calculated that a common specimen of $F$. carbasea presents more than 18,000 polypi, 396,000 tentacula, and $39,600,000$ cilia on these tentacula. How much life and active enjoyment on a small polypidom!

5. Flustra setacea, Prof. Joln Fleming.

Hab. Along with Cellipora cervicornis, from deep water, Zetland, Fleming. Height two inches; branches linear, of an inch in diameter, brittle.

6. Flustra avicularis, Fan-shaped Sea-Mat, Ellis.

Hab. Attached to other corallines and old shells, in deep water. Peterhead, on $F$. foliacea and $F$. truncata, Mr. Peach.

Our first specimens of this pretty little Flustra were from Mr. Tudor, of Bootle, attached to $F$. foliacea; our next were found by Miss M'Leish, on the banks of the Dee, below Chester, where $F$. foliacea, with this pretty parasite, is cast out by the tide and lies withering on the shore. It is about an inch in height, fan-shaped, dichotomous, segments truncate, cells oblong, with pearly capsules.

7. Flustra Murrayana, Bean.

Hab. Scarborough, Mr. Bean, very rare; coast of North- 
umberland, Miss Dale; Yorkshire and Orkney, Lieut. Thomas, R.N.; Stonehaven, Lady Keith Murray; Peterhead, Mr. Peach; Dublin Bay, M'Calla; Leith and Newhaven, on the fishermen's nets, in some abundance, D. L., jun.

This pretty little Flustra bears considerable resemblance to $F$. avicularis, but the cells, which are larger and more raised, are armed with more spines, and from various parts of the polypidom there are long tubular fibres thrown out to attach it to other bodies. It is often landed with bird'shead appendages.

\section{*** Crustaceous.}

8. Flustra memibranacea, Shagreen Sea-mat, Ellis.

Hab. On Laminaria, common.

This forms a beautiful gauze-like incrustation on the broad frond of several seaweeds, but especially of Laminaria digitata. When it is upon a narrow frond $I$ have seen it, though rarely, spreading itself a little beyond its support, and the portion that was free had cells on both sides. Young patches of it on the dark L. digitata are peculiarly beautiful, being of a pure silvery colour, with a gracefully rounded margin. The cells are quadrangular,-longer, however, than broad,-with a blunt hollow spine at each angle. 
Specimens are occasionally met with that are in some degree roughened with strap-like processes, scattered over the surface, sometimes in clusters of two or three together, about a quarter of an inch in height, of the same horny substance as the cells. They are closed at the top, and it has been conjectured that they are ovaries. The polypes have numerous tentacula, which expand in the form of a bell. "When the polypes are all protruded they form a beautiful object under the microscope, from their numbers, their delicacy, the regularity of their disposition, and the vivacity of their motions, now expanding their tentacula into a beautiful campanulate figure, now contracting the circle, and ever and anon retreating within the shelter of their cells." (Dr. Johnston.) I have elsewhere stated that I have seen a specimen of $F$. membranacea (and Dr. Jolnnston has seen its equal) five feet in length by eight inches in breadth. As every little cell had been inhabited by a living polype, by counting the cells on a square inch, I calculated that this web of silvery lace had been the work and the habitation of above two millions of industrious, and, we doubt not, happy inmates; so that a single colony, on a submarine island of a foot in length, was almost equal in number to the population of Scotland. Specimens of this 
Flustra may be seen every day on our shores, and yet many, year after year, have paced the shore without ever observing them, or only regarding them as so much grey crust, quite undeserving of their attention.

9. Flustra coriacea, E. Forbes.

Hab. On old shells. Isle of Man, Prof. Forbes ; Fowey Harbour and Peterhead, not uncommon, Mr. Peach; on old shells, dredged off Sana Island, Mr. Hyndman.

The cells broadly elliptical, having generally two hollow tubercles on the posterior angles of the aperture.

10. Flustra? lineata, Professor Jameson.

Hab. On rocks, shells, seaweeds; common.

This species spreads like a Lepralia, in round, and often in irregularly-shaped, patches. The cells are oval or oblong, sometimes with short stout spines, that meet across the cell very like Lepralia nitida, except that they are never joined. At other times the spines are long and shaggy, covering the cell; but instead of uniting, inclining towards the mouth, as we may call it, of the cell, where, in the outermost cells, the spines are so long as to form a kind of bushy beard. Several distinguished naturalists are disposed to think that this is not a distinct species, but a peculiar state of $L$. niticla or $L$. ciliata. I remember suggesting 
that this might be the case, both to Dr. Fleming and Dr. Jolnston, before I knew that the same suspicion had been entertained by persons of higher name. My attention has thus been directed to the subject for several years; and the result is, that $I$ am now disposed to think that it is a distinct species. It is exceedingly common with us; and $L$. nitida, to which it bears the greatest resemblance, is, on the west coast, exceedingly rare. When richly studded with its pearly operculums, it makes some approach to $L$. citiata when rich with opercula as the var. insignis (not rare with us) very frequently is ; but the form of the cells is quite different; and towards $L$. annulata it makes not the slightest approximation.

11. Flustra distans, Hassall.

Hab. On aquatic plants in brackish water.

Considerably more than a year ago, specimens of this curious zoophyte were sent to me by Mr. Wigham, of Norwich, who stated that he had gathered it in abundance at Yarmouth, in ditches of brackish rater, about a mile distant from the sea, and having no direct connection with it. It grew, he said, on the stems of aquatic plants. It was quite new to me, and I was advised to send it to Professor Allman, of Trinity College, Dublin, who is preparing 
a work on fresh-water zoophytes. I did so; and I had a very friendly letter from him, saying that it was very interesting, but that he would like to examine it in a living state before giving his opinion respecting it. In a letter which I lately had from Mr. Wigham, he mentions that he had shown it to Mr. Peach, who said it greatly resembled Membranipora Peachii, which he had found in the dock at Ipswich; but yet it seemed distinct; as the one found at Ipswich had three inflected spines on each cell, whereas the Yarmouth one was invariably without spines.

Corresponding lately with Mr. Busk, of Greenwich, I sent him a specimen of the Yarmouth zoophyte, and he wrote to me that it seemed to be Flustra distans of Mr. Hassall, of which he had a specimen named by our lamented friend Mr. W. Thompson. I have not at hand the volume of the 'Annals of Natural History,' in which it is figured and described by Mr. Hassall.

12. Flustra hispida, Rough Sea-mat.

Hab. In irregularly-shaped patches on Fucus serratus; commols.

This, like many other common things, possesses uncommon beauty, but as this beauty must be "sought out," not one in ten thousand ever sees anything remarkable in it. I 
confess that when seen by the naked eye, it has not much to recommend it. As it is pretty much the colour of the Fucus that it invests, it takes a trained eye to observe it at all; and when it is seen, what is it, some would say, but a brownish fleshy scarf, with some scattered spinules, giving rouglmess to what would otherwise be a smooth glistening surface? If you would look at Sir John G. Dalyell's pretty figure of it, plate ix., or if I had room to tell you all that he and the Rev. T. Hincks, of Exeter, have written respecting it, you would own that there is more in this "rough sea-mat" than at first meets the eye. "Then plunged in recent sea-water," says the Baronet, "a thin pale blue clond will be speedily interposed between its dark irregular surface and the spectator's eye. Let the vessel sustain a shock; the cloud is instantaneously dispelled, while the brownish fleshy substance remains prominent as before. This illusion may be frequently repeated. The semblance of a cloud arose from a multitude of hydra elicited from the cells whither they had retreated, to enjoy the freshness of the renovated element. Their numerous pale tentacula in motion over the darker ground, caused a misty shade."

"When immersed in sea-water, first a very short white 
cylinder protrudes, and then the integument of the body, unfolding like the inverted finger of a glove, displays the exterior of the animal, crowned by about thirty-five tentacula in campanulate arrangement. The form of the polype is elegant, light, and beautiful. It rises very leisurely from the cell; but its retreat is most precipitate, vanishing in a moment; and thus is the cloud composed of multitudes dissipated from before the observer." All this we have lately contemplated with great delight.

Not less interesting are the observations of the Rev. T. Hincks, recorded in the 'Annals of Natural History,' respecting the gemmules excluded from the fleshy moss, destined to form new polypidoms; but I must limit myself to very short extracts. The gemmule is described as very beautiful, thickly fringed with cilia round the border. "Its movements are irregular. Sometimes it creeps along, using its cilia as feet; at other times it swims pretty rapidly through the water; at others it tumbles over and over. Occasionally it floats on its back with its cilia upward, and in this state resembles a miniature boat. After a short time the cilia suddenly cease to play, the creature becomes attached, and is gradually developed into the cell and polype which are to be the nucleus of an extensive colony." 
"Earth has not a plain

So boundless or so beautiful as thine;

'The eagle's rision cannot take it in ;

The lightning's glance, too weak to sweep its space,

Sinks half-way o'er it like a wearied bird:

It is the mirror of the stars, where all

Their hosts within the coneave firmament,

Gay marehing to the music of the spheres,

Can see themselves at once."-Campbell.

\section{Genus XVII. ESCHARA, Ray.}

Gen. Char. Polypidom membrano-calcareous, inflexible, brittle, expanding in the form of foliaceous porous lamellæ, variously folded, and anastomosing, and consisting of two layers of opposite cells: cells immersed, coalescent, horizontal to the plane of the axis, opening on both surfaces in quincuncial pores, protected with an operculum.-Johnston.

1. Eschara foliacea, Stony Foliaceous Coralline, Dillenius.

Hab. In deep water. Sussex, Dillenius; Isle of Wight, Ellis ; Cornwall, Borlase and Couch; Devonshire, Dr. Coldstream. When in Devonshire I received specimens of it from Mrs. Gulson, Exmouth, and Miss Cutler, Budleigh Salterton. 
This is one of the things of which it is not easy to give a person an idea, either by drawing or by verbal description. Were a cake of ash-colour to be kneaded out broad and thin, and wrapped up in many winding folds leaving numerous caverns, and then baked or allowed to dry and become hard, something might be formed resembling our Eschara. And yet, after reading descriptions and seeing figures, I found that I had formed an incorrect idea of it. I had no notion that it was so great a thing. Mr. Couch has seen a specimen which measured seven feet four inches in circumference, and a foot and three-quarters in height. This was a monster; but one the size of a boy's head is not uncommon. The first I saw was at Mrs. Gulson's, Exmouth, and Miss Cutler, who was present, said, when I came to see her next day at Budleigh Salterton, she would have some Escharce for me; and certainly she kept her promise, for when I arrived I found that Mr. Templar and Mr. Harris had been out, and had got ready for me, not a handful, or a hatful, or a pocketful, but absolutely a large washing-tubful of living Eschara foliacea!

"When living, it is a delicate flesh-colour, which turns to a light brown in death. It is a very thin and foliaceous species, resembling a sheet of paper, waved into various 
folds. The plaits or folds often unite and form cavernous passages through the mass. The cells are small, and on both surfaces of the sheet." (Couch.)

2. Eschara fascialis, Pallas.

Hab. Deep water. Isle of Wight, Pallas.

Much the same as the preceding, but the branches are flat and narrow, and regularly subdivided.

3. Eschatia cribaria.

Hab. Deep water, in Berwick Bay.

This seems different from the preceding in form and size. In length and breadth it is less than an inch.

\section{Genus XVIII. RETEPORA, Lamarck.}

Gen. Char. Coral foliaceous, stony, fragile, netted: cells opening only on the upper or inner side, short and not prominent.-Dr. Johnston.

1. Retepora reticulata, Netted Coralline, Rev. William Borlase.

Hab. Deep water, Cornwall.

"Expanding to the extent of two or three inches; more or less cup-shaped, waved, uniting: the lobes are oval, 
regular, the intervening spaces supporting two or three pores in oblique rows." (Fleming.)

2. Retepora Beaniana, Bean's Netted Coralline, Ellis. (Plate XIX. fig. 73.) .

Hab. Deep water, rare. Shetland Islands, Jameson; Scarborough, Mr. Bean; Cape Clear, Ireland, Professor Allman ; Orkneys, Prof. E. Forbes ; coast of Northumberland, Mr. W. King; Shetland, Mr. Barlie.

This polypidom is fully an inch in height, fixed to other substances by a short, thick, hollow stalk, expanding into a cup-like form. It has a netted appearance, and the cells open only on the upper or inner side. It is a most beautiful little coral : a person might think that it was formed of fine Honiton lace, which had lost its pliancy by being frozen. The first fragment of it I ever saw I received from my kind friend Major Alexander Martin, of Ardrossan, who had got it from Shetland. Learning that better specimens of it had been dredged by Mr. Barlie in Shetland, I, through Mrs. Gulson, requested him to send a good specimen of it for a little to Mrs. Spade, of Armitage Park, Staffordshire, by whose tasteful pencil the beautiful drawing of it was prepared for our Plate, so that in this one case no less than four kind friends have concurred in obliging me. 


\section{Genus NIX. SALICORNARIA, Curier.}

Gen. Char. Polypidoms plant-like, calcarcous, dichotomous; the branches cylindrical, regularly jointed, with immersed rhomboidal cells diverging from the axis, disposed in quincunx, and opening on the surface; the aperture lateral, transverse, somewhat labiate.-Dr. Johnston.

1. Salicornaria farcimivoides, Bugle Coralline. (Plate XIX. fig. 74.)

Hab. Dublin Bay, common. Mr. Tumanowicz, Hastings; Mrs. Gatty, Yorkshire coast; Portpatrick, Rev. Mr. Urquhart; Lamlash Bay, D. L.

Dr. Johnson says, with great truth, "one of the finest of British zoophytes." Fine specimens are three inches in height. Ellis, who figures and describes it, calls it the "Bugle Coralline." "This beautiful stony coralline proceeds from trausparent membranaceous tubes which enter into and form cylindrical joints, composed of stony lozengeshaped cells, with a proper entrance into each: these surround the whole surface of the coralline." The joints which connect the different parts of the dichotomous branches are of the same substance as the fibres from which they spring; being elastic and pliable, the polypidom sustains no injury from the agitation of the sea. The joints are often blackish. 
The first specimen I saw of this was from the Rev. Andrew Urquhart, at Portpatrick, when I was only beginning to attend to zoophytes, and though it was small, I remember being much struck with its beauty. It is not found on the Ayrshire coast. I have dredged it in Lamlash Bay, Arran, but the specimens were the smallest and poorest I have ever seen.

2. Salicornaria sinuosa, Hassall.

Hab. In deep water, Mr. Hassall.

Mr. Hassall states that this differs from the ordinary species in the greater size of the cylinders, in the shape of the cells, and in the position of the apertures, which in this is placed in the upper part of each cell, while in the common one it is exactly in the centre.

\section{Tribe 3. HALCYONELLEA.}

"And Thou, Eternall Father,

Provide me (Lord) of steersman, star and boat,

That through the vast seas I may safely float:

Or rather teach me dive, that $\mathrm{I}$ may view

Deep under water, all the sealy erew,

And dropping wet, when I returne to land

Laden with spoyls, extoll thy mighty hand." -Du Bartas :

his Divine Week and Works. 


\section{Genus XX. ALCYONIDIUM, Lamouroux.}

1. Alcyonidiud gelativosum, Sea Ragged-staff, $T$. Johnson.

I never fell in with this except on Leith shore, where it is of frequent occurrence; but as it is rather ungainsome, as we say in Scotland, I shall be satisfied with giving what is said of it by 'Thomas Johnson, by whom it was first described. "This is a very succulent and fungous plant, of the thicknesse of one's thumbe; it is of a dark yellowish colour, and buncheth forth on everie side with many unequal tuberosities or knots; whereupon Mr. Thomas Hickes, being in our company, did fitly name it Sea Ragged-staffe."

2. Alcyonidium hinsutum, Dr. Fleming.

Hab. On seaweeds and Flustia at low-water.

This is of a more compact substance than $A$. gelatinosum, and though, like it, it has not much external beauty to catch the eye, by reading what is said of it by Dr. Johnston we may see that it will fully repay minute investigation. Having mentioned that it is marked with numerous yellowish circular spots, which are found to be clusters of ova, he adds, "The egg is clothed with cilia of equal size and shape, and all inclined in one direction, moving with a 
uniformity and quickness which is admirable, and very pleasing to the beholder. When the egg is at rest, their velocity is not diminished, excepting at the will, so to speak, of the ovum, for it may be seen to become slower and less constant, to cease entirely for a moment, and again be renerred with its former force. The egg, at rest, will at once start from its place, and swim about hither and thither, as it were endowed with volition, turning on its axis frequently, moving sometimes on one side, sometimes on the edge, when the cilia become invisible. By their motion they drive a current of water over the surface."

3. Alcyonidium parasiticum, Dr. Fleming.

Hab. On the stalks of Sertulariade.

This is like a blackish-brown earthy coating on several of the corallines. The doubts respecting its nature have been dispelled by the researches of Mr. Hassall, Van Beneden, and Professor Reid. An interesting account of it by Professor Reid may be found in Dr. Jolinston's work, page 362.

\section{Genus XXI. CYCLOUM, Hassall.}

Gen. Char. Polypidom fleshy, encrusting, covered with numerous imperforate papillæ.-Hassall. 


\section{Cycloum papillosum, Massall.}

Hab: Parasitical on Fucus serratus.

This zoophyte, as well as the succeeding species, exhibits in a very remarkable degree the close adhesion to life, the usual accompaniment of a low organization, for after being coated over with ice, should they be immersed in sea-water the polypes will protrude their feelers and appear as active as if they had never been subjected to any such treatment.

\section{Genus XXII. SARCOCHITUM, Massall.}

Gen. Char. Polypidom encrusting, fleshy, covered with numerous prominences of irregular form and unequal size, from which the polypes issue; ova circular, scattered; a dark-brown body of a circular form, filled with small round grannles, is apparent in great numbers through the polypidom.

1. Sarcochitum polyoum, Massall.

Hab. Parasitical on Fucus serratus.

\section{Tribe 4. VESICULARINA.}

"God, who gifted his creature man with an inquiring spirit, and with an appetite for knowledge of the works of ereation, - to furnish him with objects of inquiry, and to gratify that appetite to the utmost, not only ornamented the dry land with what was fair to look upon, - not only placed before his eyes on the earth an innumerable host of ereatures, of which he could gain 
a notion by only opening his eyes, and by observing their beauties, and expericncing their utility, might praise his Maker for them;-but also filled the deep with inhabitants, and ornamented it with animals, which appearing to vegetate and blossom like plants, his curiosity being excited, he might also study the inhabitants of the water, and glorify his Maker for the creation of them."-Kirby's Bridgewater Treatise.

\section{Genus XXIII. SERIALARIA, Lamarck.}

Gen. Char. Polypidom confervoid, horny, the shoots slender, filiform, fistular and branched; cells tubulous, uniserial and unilateral, disposed in close parallel companies at stated intervals. Polypes ascidian. - Dr. Jolnston.

1. Sertalaria lendigera, NitCoralline. (Pl.XIX. fig.76.)

Hab. On seaweeds of various kinds, though, like many other corallines, partial to Halidrys.

It is common on many of the shores of England and Ireland, and though we have not found it on our western shores, it has been got in abundance in the Firth of Forth, by D. L., jun., and others. It has been called the Nit Coralline, and when we look at it with the naked eye we are reminded of what we have seen on the heads of neglected children; but we have only to apply the lens, and our thoughts are immediately turned away from filth, to the groves of Arcadia, for what had seemed a nit is seen exactly to resemble a little Pan-pipe; so that, if we could 
summon the Dryads, and convert them into a marine band of Nereids, there might, from groves of tangle, burst forth music,

"Like harp Nolian's swect acrial notes."

The height of the polypidom is an inch and upwards, dichotomously divided; cells numerous.

\section{Genus XXIV. VESICULARIA, J. $V$. Thompson.}

Gen. Char. Polypidom rooted, confervoid, fistular, horny, dichotomously branched, jointed at the divisions : cells ovate, disjunct, uniserial and unilateral.

1. Tesicularia spinosa, Silk Coralline, Dillenius. (Plate XX. fig. 77.)

Hab. On oyster-beds, Dr. Fleming; shores of Ireland, W. Thompson; Mersey, Mr. Tudor; Leith shore, D. L., jun.

This, from its fineness, has been called Sea-silk Coralline: the stem is formed by fine silken threads, united, and the ramifications arise from this with a zigzag stalk. In the small branches appear rows of holes with a rim, as if bored from within outwards. The vesicles are of an oval shape, and open at the top. They are so delicate that they can with difficulty be seen; but when they are seen, they 


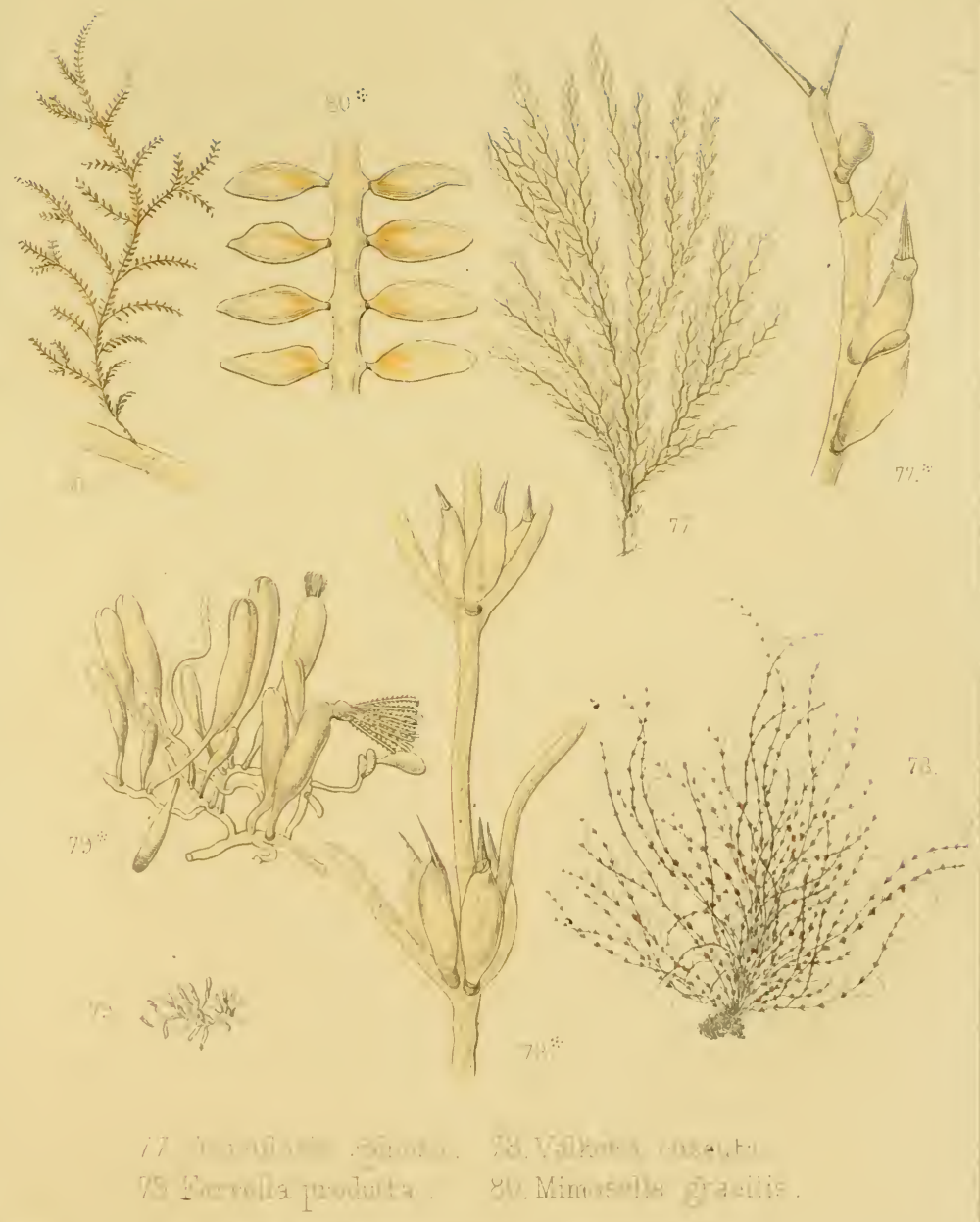



are so thin and transparent that the polype can be discerned through the walls. They have eight tentacula.

This, though common in many places, does not occur on our Ayrshire coast. I have gathered it at Liverpool, and at Portrush, Ireland.

\section{Genus XXV. BEANIA, Johnston.}

Gen. Char. Polypidom confervoid, horny ; the shoots creeping, filiform, tubular, irregularly divided; the cells very large, sessile, erect, scattered and solitary, ovate, with a double spinous keel on one side. Polypes unknown.

1. Beania mirabilis, $W$. Bean. (Plate XIX. fig. 75.)

Hab. On bivalve shells, or on the roots of Cellularia avicularis, very rare. Scarborough, Mr. Bean; dredged off Scilly, Mr. M'Andrew; attacked to a cork, near Falmouth, W. P. Cocks; Sidmouth, Mrs. Gatty; Exmouth, Miss Cutler; Salcombe, Rev. T. Hincks; Peterhead, one specimen, Mr. Peach.

Dr. Johnston says, "This remarkable genus was discovered by Mr. William Bean of Scarborough. I felt much gratified in associating it with his name. He is well known to naturalists generally, by his multitudinous discoveries in British zoology, recent and fossil." 
This very remarkable coralline is so insignificant when seen by the naked eye, that it would be passed over as undeserving of regard, except by those who have been accustomed to scrutinize the "minims of nature." The only specimen I ever had of it I received from Mrs. Gatty. In describing the cells, she compared them to little beetles that had lost their head. This is an apt comparison. As the stalk creeps along shells, one is ready to suppose that, if the head were away, the cells would creep also. The aperture of the cell is quadrangular, and partly clothed with a thin membrane.

\section{Genus XXVI. VALKERIA, Fleming.}

Gen. Char. Polypidoms confervoid, fistular, membranous, and variously branched: cells clustered, ovate, with a narrow base. "Polypes with eight regularly ciliated tentacula." No gizzard. -Johnston.

1. Valkeria Cuscuta, Dodder Coralline. (Pl. XX.fig. 78.)

Hab. West coast of England, Ellis; Devonshire, Mrs. Griffiths; Exmouth, rock-pools, Rev. Mr. Hincks; Isle of Wight, Mr. W. Thompson; Leith shore, Jameson; Polperro, Mr. Couch; north of Ireland, Mr. W. Thompson; coast of Ayrshire, D. L. 
A good description of this interesting and beautiful zoophyte is given by Professor Fleming, by whom the genus was named in honour of the late Dr. Walker, Professor of Natural History in the University of Edinburgh. The stems usually arise from the base, filiform, jointed, and support the branches and cells bifariously: the cells are oval and large; often they occur in whorls in the axillæ of the branches; the polypi extend beyond the margin; tentacula with hairs, which, by their motions, cause the water to ascend in a current on one side and descend on the other, acting, as is supposed, as aerating organs." This is got in great beauty, and at times in considerable abundance, on the coast of Ayrshire. Dr. Fleming states that it is seldom above two inches in height, but on Halidrys siliquosa we have occasionally seen it four inches. Halidrys is its favourite; but it is often found on Rhodymenia lifida, though of smaller size than when on Halidrys. It is of a pale yellowish colour, and makes a handsome specimen on paper, to which it firmly adheres. I find that it is phosphorescent when shaken in the dark.

2. Valkeria uva, Grape Coralline, Ellis.

Hab. Leith, Jameson; county Down, Templeton; Couch, Cornwall ; Dublin Bay, Hassall. 
Ellis found this little coralline creeping on the surface of Flustra foliacea, each of the vesicles having a black spot, like the spawn of frogs, or rather like grapes with the seeds in them. When seen through the microscope, he saw that these grape-like bodies were clusters of very lively polypes, extending their tentacula in pursuit of prey. What he had seen as dark spots were the dead polypes in their cells.

3. Valkeria pustulosa, Pimpled Coralline, Ellis; Dichotomous Tubular Coralline.

Hab. Isle of Wight, Ellis; Salcombe, Rev. T. Hincks; Cove Harbour, J. V. Thompson; Youghal, Miss Ball; Belfast Bay, IV. Thompson; Dublin Bay, A. H. Hassall; Cornwall, rare, Mr. Peach; Leith shore, rare, D. L., junior.

It appears through the microscope full of pustules, with a speck in the middle of each. It is two or thrce inches in height. The branches are perforated by a double row of holes, in which there are polypes with eight tentacula.

\section{Genus XXVII. BOWERBANKIA, Fare.}

Gen. Char. Polypidom confervoid, matted or irregularly branched; the cells sessile, unilateral, irregular, the inflected portion with a spinous or filamented rim. Polypes ascidian, with a strong gizzard. 
1. Bowerbankia imbricata, Adams.

Hab. Parasitical on Fuci, and not uncommon. Exmouth, rock-pools, and cast ashore in great masses, Rev. T. Hincks ; Frith of Forth, D. L. jun.; Southampton and Portsmouth, on the chains of the steam-ferries, Dr. Johnston.

It is about an inch in height, in flaccid tufts. The branches are smooth and transparent, in clusters on one side, leaving the opposite side of the branch bare. When the animal is expanded it has ten tentacula; when alarmed it contracts very rapidly, shutting itself up in a transparent horny cell. The cells are connected by a cylindrical creeping stem, on which they are thickly set.

\section{Genus XXVIII. FARRELLA, Ehrenberg.}

Gen. Char. Polypidom confervoid, creeping, fistular and mem. branous; the cells elliptical, scattered. Polypes ascidian, with the tentacula forming a rather incomplete circle: no gizzard: ova on exclusion without cilia.

1. Farkella repens, A. Farre.

Hab. Parasitic with a creeping stem on Sertularia, Dr. Farre; in Strangford Lough, on seaweeds, W. Thompson. "The cells have an oblong form, and are connected with 
their narrow creeping stem by a short peduncle. The opercular portion terminates in a notched margin, and is very short. The cells spring from the sides and upper surface of the stem, and turn upwards as in Bowerbankia. They are set at some distance apart." (Farre.)

2. Farrella producta, Hincks. (Plate XX. fig. 79.)

Hab. On the Fleetwood buoy, T. Hincks.

This was discovered by the Rev. Thomas Hincks, of Exeter, who has kindly sent for my use his paper in the 'Annals,' containing so much interesting matter respecting Mimosella, Farrella, and other zoophytes. The following is his description of this new species. The cells, which are more slender than those of $F$. repens, are produced below into a long, gently tapering pedicle, which connects them with a creeping fibre. This is equal to the cell in length, or exceeds it; it becomes much attenuated towards the base. A thread of matter passes down from the bottom of the stomach through the pedicle. The cells are generally set a little obliquely on their stalks. The polypes have twelve arms, and exhibit a structure like that of $F$. repens. It may be known at once by its long and tapering pedicle." (Hincks.) 


\section{Family PEDICELLIN 2 . \\ Genus XXIX. PEDICELLINA, Sars.}

Gen. Char. Polypes invested with a thin transparent polypidom, pedicled, clavate, rising from a filiform creeping shoot. The club abdominal, oblong, dilatable, encircled above with a series of short ciliated tentacula, which roll themselves up when at rest, and are not withdrawn into the polypidom.-Dr. Johnston.

1. Pedicellina echinata, Ellis.

Hab. Parasitical on corallines and seaweeds between tidemarks, but especially near low-water mark.

Polypes gregarious or clustered, from a creeping transparent fibre. Hassall had called it Cardua, from the great resemblance which the polypes bear to the heads of thistles, which is strengthened by the presence of hairs upon their surface.

2. Pedicellina gracilis.

Hab. On a buoy moored near Fleetwood, Hincks; on the coast of Scotland, Mr. Goodsir.

Abundance of fine specimens of this species were got by the Rev. Mr. Hincks at the above-mentioned habitat. The most marked character is the expansion of the stem towards 
the base. It is very hardy. It was transported by Mr. Hincks in a small bottle, about 300 miles, from Lancashire to Exeter, and though he was unable to renew the water, it continued to live with him for some days.

3. Pedicelitisa Belgica.

Hab. On seaweeds on rocks near low-water mark, Exmouth, Rev. T. Hincks.

"Tentacula twelve, equal in length, a little shorter than the body : stem and pedicle smooth." "Without spines."

Genus XXX. MIMOSELLA, Hincks.

Gen. Char. Polypidom rooted, confervoid, horny, jointed and variously branched: cells ovate, biserial, opposite, with a basal joint, by means of which they can be moved to and fro, and folded together on the branches. Polypes with eight tentacula. -Hincks.

1. Mimosella gracilis, Hincks. (Plate XX. fig. S0.)

Hab. Dredged in Salcombe Bay, Devonshire, profusely investing a bunch of seaweed, Hincks.

Of this beautiful creature I quote the following account by the Rev. T. Hincks, who had the pleasure of adding it to our Rritish Fauna. 
From a creeping fibre, which spreads over the surface of Fuci, rise graceful, tapering stems, pinnate, much attenuated towards their extremities, and running out into filamentary, tendril-like prolongations. These stems are commonly from an inch to an inch and a half in height. They are jointed at intervals; and immediately below each joint spring two opposite pinnæ, also jointed, tapering, and slightly curved. "The pairs of pinnæ do not all lie in the same plane. Along these are set the cells, which are ovate, elongate, biserial, and opposite. Each cell is attached to a small prominence on the side of the pinna, which is perforated. A circular orifice on one side of the cell near the base fits over this, and a joint is thus secured, by means of which the polype can move its dwelling forward in one direction and back again. This is frequently done. The polypes are continually swaying their cells to and fro; sometimes all the cells on the pinna are folded together on the upper side, just as the leaflets close on the leaf of the sensitiveplant (Mimosa), and hence the generic name. Towards the base of each pinna the cells are long and oval; as they approach the apex they became short and globose, and at last are little more than little round excrescences.

"The polypes have eight arms, and are furnished with a 
gizzard. They are very vigorous in their movements. It is very interesting to watch the little creatures manœuvring their cells. Every now and then, as if some common impulse stirred them, all the polypes on a single pinna will move forward their cells, and the frond close like the Mimosa-leaf when touched. More commonly they are independent in their movements. A single cell here and there will be seen in motion, while the rest remain quiet.

"The mouth of the cell is furnished with the characteristic setæ of the family. When the cells are detached, the circular opening near the base may easily be detected." (Hincks.)

\section{POLYZOA HYPPOCREPIA.}

The following is Professor Allman's arrangement of the genera :-

Polype-mass floating. Cristatellide.

One genus only-Cristatella.

Polype-mass rooted.

† Massive or confervoid, inarticulate. Plumatellide. Massive and sponge-like. Alcyonella.

Confervoid, tentacular disc crescentic. Plumratella. 
Confervoid, tentacular disc orbicular. Fredericella. †† Confervoid, jointed. Paludicellaide.

One genus only-PaLudicella.

\section{Genus XXXI. CRISTATELLA, Cuvier.}

1. Cristatella mucedo, Sir John G. Dalyell.

Hab. In the fresh-waters of Scotland, Sir J. G. Dalyell; and those of Ireland, Prof. Allman.

As I expect that I am going beyond my limited space, I must not attempt to give a description, but refer the reader to Sir John G. Dalyell, Dr. Johnston, and Professor Allman.

\section{Genus XXXII. ALCYONELLA, Lamarck.}

\section{Alcyonella stagnorum.}

Hab. Stagnant waters, especially such as are tinctured with iron in solution. Mr. Wigham, of Norwich, wrote to me that he had found it in the dock at Ipswich, in saltwater. May it not be a different species? Pages of interesting matter may be found on this in Dr. Johnston's 'History of Zoophytes.' 
Genus XXXIII. FREDERICELL $1, P$. Gervais.

1. Fredericella Sultana, Prof. John Fleming.

Hab. Lochmill Loch, Fife, Dr. Fleming; Berwickshire, Sir John G. Dalyell; near Penzance, Mr. Ralfs; Bandon, Dublin, Prof. Allman.

2. Fredericella dilatata.

Hab. Fresh-water, near Dublin, Prof. Allman.

Genus XXXIV. PALUDICELLA, Gervais.

1. Paludicella articulata, $W$. Thompson.

Hab. Lough Erne, W. Thompson; Grand Canal, near Dublin, A. J. Allman.

Genus XXXV. PLUMATELLA, Bosc.

1. Plumatella emarginata.

Hab. Fresh-water, Dublin, Prof. Allman.

2. Plumatella fruticosa.

Hab. Fresh-water, Dublin, Prof. Allman.

3. Plumatella repens, Prof. John Fleming.

Hab. On the under side of stones, Lochmill Loch, Fife, Dr. Fleming; Norton, Durham, Mr. Hogg; Lough Erne, W. Thompson; near Glasgow, Dr. Scouler; Cheshunt, Mr. 
Hassall; near Dublin, Prof. Allman; Ayrshire, in a quarrypond on the under side of stones, and in lakes on the under side of the leaf of Nymphaa alba (are they the same species?), D. L.

I have reserved this to the last, that I may close this little work with an account of Plumatella repens, which I wrote for a periodical about ten years ago, when it had, to me, the charm of novelty.

It is called Plumatella, which is a diminutive of the Latin word signifying plumed; and the specific name repens is given, because it is generally found creeping along the under surface of stones and of leaves. It has been seldom found in Scotland. When taken out of the water, it has no beauty to attract the eye; but when replaced in the water in such a position as that it can be contemplated with the aid of a lens, what is beheld is both beautiful and wonderful. When regarded with the naked eye, all that at first is seen is the appearance of horny, leafless branches proceeding from a centre, and setting out at short intervals along the branches, and generally in pairs, what seem like leaf-buds. In a little, however, there is the appcarance of life, and what was a naked leafless branch assumes a downy appearance. The cause of this, by narrow inspection, can 
be ascertained even with the naked eye. By the aid of a lens, however, the nature of the change is much more evident. You then see that the branches are tubes, inhabited by living creatures; - that long bud is a cell, the dwellingplace of a polype; that there may be above a hundred of these clustered together; and that as one stone may have several distinct villages planted upon it, the whole population of a district of six square inches may be upwards of a thousand. The first symptoms of life that the observer perceives is the polype, which had shrunk out of sight on being disturbed, pushing forward to the mouth of the cell, as if to reconnoitre. If all is quiet, you will soon see the polype, in the form of a little white rod, protrude from the cell in a horizontal direction. This rod is composed of a bundle of tentacula, amountiug to about fifty. The next change that takes place is the unfolding of the tentacula; not in the star-like form assumed by the Mydra, but in the form of two horse-shoes, the one enclosing the other. The outer and larger horse-shoe is spread out like a lady's ivory fan. The inner range is unfolded in the same manner, but it is of smaller dimensions. There is something remarkably elegant in this form of the polype; and though it is the more usual aspect, it is not the only one. There is another 
of still greater elegance, which seemed to be a favourite one, and which we have seen assumed by above a hundred of the polypes at once. In this case, the outer range, consisting of twenty-six tentacula, was spread out in the graceful manner we have mentioned. The inner range, however, was made to resemble an elegant pavilion, the opposite tentacula meeting together at the top in the form of a Gothic arch. Taking a survey of the whole, however, it had the appearance of a tented field, where a miniature army lay encamped;-or, as there was so much more grace and elegance than soldiers' tents exhibit, you were led to think of some splendid tournay, where the princes and nobles of the land had in all their pomp assembled, vying with each other in the magnificence of their pavilions, with which the plain far and wide was studded.

And gay as it was, it was a field of warfare. The polypes were not the only inhabitants of the watery plain: it was inhabited also by Infusoria; many of which, green, and white, and grey, could be seen with the naked eye, wantoning in all the joy of active life. 'It was to trepan these little thoughtless " minims of nature" that the tentacula of the Plumatella were thus artfully spread out. Elegant as the arched pavilion might appear, it was to them the cham- 
ber of death. Means unseen were employed to lure the little sportive animalcules into the well-laid snare. Every one of the feelers was fringed with numerous cilia, too minute to be seen without the aid of a powerful microscope; and which were constantly in motion, to produce currents which might insensibly draw the little infusories into the inner or outer enclosure, like Scylla and Charybdis, prepared for their destruction. Let them but touch, in their heedless gambols, one of the extended feelers, and, with the suddenness of the lightning's flash, the whole were closed and withdrawn into the cell; and by the very act of withdrawal, the cell was shut, and escape rendered utterly impossible!

What has been said respecting the beautiful Plumatella may serve to "point a moral" and to teach us some lessons of wisdom.

We blame not the Plumatella for catching its prey-it is guided by instinct in doing so; and even though it had been guided by reason, it would have been as little reprehensible as the wild Indian, who subsists by his skill in fishing and in the chase : and yet it may remind us of those who are deeply culpable, and have a fearful responsibility. In looking at the beautiful pavilion-like display made by the Plumatella, 
though the natural feeling is that of admiration, we may, by no very unnatural process, be led to think of the tents of sin-of the palaces of pollution-reared by those who make merchandize of souls; who, for "filthy lucre," ply every wile suited to the corrupt propensities of the human heart. In looking at the little infusories on the verge of destruction, I could not help thinking with pity on the multitude of infatuated mortals who "go as oxen to the slaughter,-as birds to the snare, and know not that it is for their life." In them we might regard as verified the ancient fable of warriors changed into swine by partaking of Circe's cup: and when the fable tells how. the veteran chief was preserved from falling under the power of the enchantress, by a herb given him by a friendly deity, should we forget, that even to those whom the cup of sinful pleasure has degraded and sunk below the level of the most polluted of the brutes, there is offered free access to the tree of life, "the leaves of which are for the healing of the nations ;" of which if the degraded eat, they are raised not only to the rank of men, but are made partakers of the Divine nature, "being renewed in the whole man after the image of God." How thankful should we be that the way to this blessed tree is, by Him who loved us, laid open to 
all; that it can not only keep us from the fascinations of sinful pleasure, but that it can bless us with exalted pleasures during our earthly pilgrimage, and bring us to a land of eternal joy. Child of the dust! wilt thou reject the gracious offer? Wilt thou put away from thee the richest blessings, to drink deadly poison from a gilded cup? "When sinners entice thee, consent thou not." When pleasure plies her deceitful wiles, know that "by her many have been cast down wounded, and many strong men have been slain." "Enter not then into the path of the wicked; go not the way of evil men. Avoid it, pass not by it; turn from it, and pass away." Say, "One thing have I desired of the Lord, and that will I seek after, that I may dwell in the house of the Lord all the days of my life, that I may behold the beauty of the Lord, and inquire in his temple; for in the time of trouble he will hide me in his pavilion; in the secret of his tabernacle he will hide me; he will set ine upon a rock." 


\section{GLOSSARY.}

Abbreviate, disproportionally short in the part.

Abdomen, the lower part of the body, the belly.

Abnormal, irregular, departing from the usual form.

Aculeated, furnished with prickles.

Acuminated, with a long tapering point.

Adiaphanous, not in the least transparent.

Adnate, adhering or growing together.

Agglutinated, united by some viseous fluid, as glue.

Albuminous, consisting of albumen like the white of an egg.

Alveolate, deeply pitted, so as to resemble a honeyeomb.

Amorphous, devoid of regular form.

Anal, pertaining to the anus or rent.

Analogous, bearing some proportion or resemblance.

Anastomose, when the mouths of two vessels unite.

Annulated, marked with distinct rings. 
Anomalous, deriating from a general rule.

Anteal, in front of anything, forward.

Anterior, going before.

Aperture, a hole, any opening.

Apex, the top of anything; apices, the tops.

Apical, belonging to the apex or top, pointed.

Appressed, approaching the stem or branch so as to be nearly in

the same direction.

Arborescent, branched, resembling a tree.

Arcuated, bent in the form of an arch.

Areolate, marked with lines, so as to gire the appearance of network.

Articulated, jointed.

Attenuated, gradually tapering tomards the apex or base.

Auricle, the external ear, a little ear.

Avertebrate, without vertebræ or backbone.

Axillary, in the angle called the axil, formed by the junction of stem and branch.

Axis, the central portion, or main stem.

Basal, pertaining to the base.

Bicuspid, having two points.

Bifurious, parting in opposite directions.

Bifil, cleft into two segments, haring a deep noteh down the centre.

Bilabiate, having two lips.

Biserial, in two rows. 
Branchice, the respiratory organs, which extract oxygen from the air contained in water.

Bronchial, relating to the bronchi or ramifications of the wind-

pipe in the lungs.

Bulbules, little bulbs.

Caducous, falling off.

Calcareous, partaking of the nature of lime.

Callous, hardened, of a horny or cartilaginous substance.

Callus, any horny or bony excrescence.

Campanulate, bell-shaped.

Canaliculated, made like a groove, canal, or furrow.

Cuncellated, having transverse lines crossing longitudinal ones at right angles.

Capillary, fine and long, resembling hair.

Capsules, small pitcher-shaped bodies.

Carinated, having a longitudinal prominence like a keel.

Carnivorous, subsisting on flesh.

Carnose, of a fleshy substance.

Cartilage, a smooth, solid, elastic substance, softer than bone.

Catenulate, consisting of little links or chains.

Caudal, pertaining to the tail.

Caudate, having a tail.

Caulescent, having a stem.

Cellular, consisting of cells, as the cellular tissue in animals.

Ciliated, furnished with cilia or vibratile hair-like filaments resembling the eyelashes. 
Cinereous, ash-coloured.

Clavate, elub-shaped.

Concentric, having a common eentre.

Conoid, resembling a cone.

Continuous, without interruption, prolonged.

Contorted, twisted, or leaning on each other obliquely.

Convex, swelling on the exterior surface into a spherical form

Convolute, twisted spirally.

Cordate, heart-shaped at the base ; obcordate, heart-shaped at the apex.

Coriaceous, of a leathery consistenee.

Curneous, horny.

Corrugate, to wrinkle.

Crenated, notched.

Crescentic, like the moon in a state of inerease.

Cuneate, shaped like a wedge.

Cylindrical, round and elongated.

Cyst, a bag or tunic.

Denticulated, set with small teeth.

Deltoid, triangular.

Dendritic, branched like a tree.

Dextral, on the right.

Dirphanous, clear and transparent.

Diaphragm, the midriff, which divides the upper cavity of the body from the lower.

Dirletomous, dividing regularly in pairs. 
Didymous, in pairs.

Disc, the surface with the margin or the flat base of adherence.

Dissepiment, a partition.

Distal, opposed to anteal.

Distichous, placed in two opposite rows.

Divaricate, spreading out widely.

Dredge, a drag-net for taking mollusca, zoophytes, etc.

Echinated, set with spines, or bristled like a hedgehog.

Edentulous, toothless.

Elliptical, oral, but having the longitudinal diameter twice the length of the transverse.

Emarginate, notched on the margin.

Ensiform, shaped like a sword.

Epidermis, the outer covering, or scarf-skin.

Erose, irregularly notched, as if gnawed.

Everted, turned outward.

Falcate, bent like a scythe.

Fasciculate, tufted and level-topped.

Fauna, the animals peculiar to any country.

Filiform, thread-shaped.

Fimbriated, fringed.

Fissuve, a little cleft.

Fistular, like a pipe.

Flabelliform, fan-shaped.

Flexuous, bending, gently winding. 
Fluviatile, belonging to rivers.

Foliaceous, leaf-like.

Foraminous, full of holes.

Fosses, ditch-like depressions.

Frondose, like a cryptogamic plant, that has no leaves distinct from the stem.

Furcate, divided at the end into two prongs or branches.

Fusiform, spindle-shaped.

Ganglion, a mass of nerrous matter from which nerves radiate.

Gelatinous, composed of jelly-like substance.

Gemmules, little buds.

Geniculated, bent so as to form a knee or angle.

Gibbose, having one or more large elevations.

Glabrous, having a smooth surface.

Globule, a small particle of matter having a spherical form.

Glutinous, viscid, having the quality of glue.

Granulated, covered with granules or little grains.

Gregarious, found together like a flock.

Griseous, white mottled with black or brown.

Habitat, the natural place of permanent abode.

Hamiform, curred at the extremity like a hook.

Hastate, shaped like a spear.

Helianthoid, like a sunflower.

Hirsute, thickly set with long stiffish hairs, shaggy.

Hispid, beset with bristles or stiff hairs.

Hyaline, glossy, pellucid. 
Imbricated, lapping over each other like the tiles of a house. Inarticulate, without joints.

Incrassated, thickened in any part.

Incurved, bent inwards.

Inflected, bent inwards.

Inosculation, the union of two vessels at their extremities.

Integument, a natural covering of the body, as the skin.

Interstice, the space between elerations and depressions.

Invertebrate, destitute of a backbone.

Involute, rolled inwards.

Iridescent, having colours like the rainbow.

Juncture, a joint or articulation.

Labial, pertaining to the lip.

Lamellated, dirided into layers or plates.

Lanceolate, tapering to a point like a lance.

$\operatorname{Larynx}$, the upper part of the windpipe.

Latticed, in open squares like net-work.

Lobed, having lobes or broad finger-like divisions.

Lunated, in the shape of a crescent.

Mammillated, haring little globes like nipples.

Mesial or Medial, placed in the middle.

Mucronate, ending in a mucro or sharp rigid point.

Yuricated, rough with points.

Nascent, beginning to exist. 
Nodose, having knobs or swellings.

Nodule, a little knot-like eminence.

Oblique, running sideways.

Obsolete, partially indistinct, not well defined.

Esophagus, the gullet.

Opake, not transparent.

Operculum, a lid or cover.

Ordinate, when spots, etc., are placed in rows.

Orifice, an opening; the moutl.

Oval, haring the longitudinal twice the length of the transverse diameter.

Ovary, the part in which ova or eggs are formed.

Ovate, shaped like the longitudinal section of an egg.

Oviparous, produced by eggs hatched after exclusion from the body.

Ovoriviparous, when the eggs are hatehed in the body of the animal and exeluded alire.

Ovisac, egg-bag.

Ovoid, approaching to the shape of an egg.

Palmated, shaped like the hand with the fingers extended.

Panicled, in a loose spike.

Parasitic, existing on some other body.

Parenchyma, spongy matter; the pith.

Paricles, walls.

Pectinated, resembling the teeth of a comb. 
Peduncle, pedicle, a footstalk on which anything is situated.

Pelagic, belonging to the deep sea.

Pentangular, having five angles or corners.

Perforate, having holes as if bored with a sharp instrument.

Petaloid, having the form of petals.

Phosphorescent, shining in the dark, like the glowworn.

Physiological, relating to the functions of living beings.

Phytoidal, like a plant.

Pinnated, ninged.

Pinnatifid, eut transversely into oblong segments.

Plicate, plaited.

Plumose, feathery.

Polymorphous, having many forms.

Polypidom, the house of the polypes.

Polypiferous, bearing polypes.

Posterior, placed after.

Prehcnsile, grasping.

Proboscidiform, shaped like the trunk of an elephant.

Process, a natural appendage of an animal.

Proliferous, fertile, productive.

Proximal, before the mouth.

Pullulate, to bud.

Punctucted, covered with points or dots.

Pyriform, pear-shaped.

Quadrifarious, arising from all sides of the stem or branch. Quadrifid, cleft in four parts. 
Quincunx, disposed in squares, with one at each corner and a fifth in the middle.

Racemous, growing in clusters.

Rachis, the stem.

Radiated, sending forth rays from a centre.

Ramous, branched.

Reniform, kidney-shaped.

Reticulated, formed like net-work.

Retractile, capable of being drawn backwards.

Revolute, rolled outward and backward.

Rhomboidal, like a rhomb, a quadrangular figure with two angles acute and two obtuse.

Rugose, wrinkled.

Succate, in the form of a bag.

Scutiform, having the shape of a shield.

Secund, when the branchlets are on one side.

Semi, in composition signifies half.

Sericeous, silky.

Serrate, toothed or notched.

Sessile, attached without a peduncle or stem.

Setaceous, bristly.

Sinistral, left.

Sinuated, haring curved breaks in the margin like bays.

Sinus, a depression.

Siphon, a cylindrical tube. 
Spathulate, rounded and broad at the end, and becoming narrow like a spatula.

Spinous, armed with spines.

Squamose, scaly.

Stellate, consisting of star-like figures.

Striated, marked with fine lines.

Sub, in composition signifies approaching to.

Subulate, awl-shaped.

Sulcate, furrowed.

Tentacula, feelers.

Terminal, forming the extremity.

Tessellated, chequered like a chess-board.

Transverse, crossing each other when the longitudinal line is cut through at right angles.

Truncated, eut across, terminating abruptly.

Tubercle, a little pimple-like knob.

Tubular, in the shape of a tube, hollow and cylindrical.

Type, a general form, such as is common to the species of a genus.

Uncinated, set or corered with bent spines like hooks.

Undulated, having a wared surface.

Unilateral, existing on one side only. -

Urceolate, swelling in the middle like a piteher.

Variolous, resembling small-pox.

Tascular, pertaining to the vessels of animal bodies. 
Ventricose, swollen in the middle.

Vermicular, resembling a worm.

Verrucose, corered with tubercles like warts.

V'ertebrate, haring a baekbone.

Verticillate, whorled.

Vesicle, a little bladder.

Vibratile, when there is a constant oscillating motion of any part.

Tiscous, elammy.

riviparous. bringing forth the young alive, not by eggs.

Zigzag. haring short turnings and angles. 


\section{N D E X.}

(The names of the Classes and Orders are in small capitals, those of the Tribes and Families in Italics.)

Page

24.5

anguicoma...... 246 Bellis ........ 253 biserialis ....... 248 chioiocca....... 243 Chrysanthellum... 247 chrysosplenium ... 243 coccinea ....... 244 coriacea ...... 249 crassicornis..... 251 Dianthus....... 254

-— Dianthus. . . . . . . 254

—-gemmacea ...... 248 intestinalis ..... 247 margaritifera..... 243 Mesembryanthemum 242 monile. ...... 249
Actinia parasitica..... 253 Troglodytes .... . 244 — vermicularis . . . . 248 - viduata ........ 244 Actiniade......... 226 Adamsia palliata ..... 229 Alcyonella stagnorum. . . 379 Alcyonida......... 214 Alcyonidium gelatinosum 364 - hirsutum...... 364 — parasiticum ..... 365 Alcyonium digitatum... 214 - glomeratum.....216 Alecto dilatans....... 280 — granulata ..... 279 - major ....... 279 
Page

Inguinaria spathulata .. 287

Cellipora Skenii . . . . . 300 truncata ...... 288

Antennularia antennina. . 141

ramosa ...... 142

Anthea Cereus ....... 258

- Tuedix ....... 259

Axtiozoa ...... 75, 103

Asteroida . . 75, 192

Helianthorda 76, 217

Hydroida, 75, 77, 103

Beania mirabilis ...... 369

Bowerbankia imbricata. . 373

Campanularia dumosa . . 168

integra ....... 165

intertexta . . . . 166

lacerata...... . 167

— syringa ....... 166

— verticillata ..... 167

— volubilis ....... 163

Campanulariada ...... 158

Capnea sanguinca ..... 227

Caryophyllea Smithii ... 223

Cellipora cervicornis ... 301

vitrina. . . . . . 302

Celliporida......... 299

Celliporina......... 285

Cellularia avicularia .... 341

— ciliata . . . . . . . 337

— Hookeri ....... 340

- neritina ....... 341

- Pcachii ........ 342

— plumosa ....... 342

— reptans . . . . . . . 339

— scruposa ...... 339

— termata ....... 339

Classification ........ 63

Clava multicornis...... 104

Cordylophora lacustris. . 107

Corymorpha nutans .... 119

Corynactes viridis. . . . . 227

Coryne pusilla ....... 105

Corynida ......... 103

Crisia aculenta ....... 282

— denticulata ..... 282

- cburnca ........ 281

— geniculata ...... 283

Crisiadre........... 281

Crisidia cornuta ....... 254 
Crisidia setacea........ 284

Fredericella dilatata . . . 380

Cristatella mucedo ..... 379 Sultana....... 380

Cycloum papillosum ... 366 Diastopora obelia..... 276

Eschara cribaria...... 360

— fascialis....... 360

— foliacea ........ 358

Escharida. .......... 333

Eucratea chelata...... 286

Eucratiada......... 285

Eudendrium rameum ... 108

- ramosum....... 111

Farella producta. ..... 374

Gemellaria loriculata. . . 296

Gemicellaria Bursaria. . 297

Glossary........... 387

Gorgonia anceps ..... 207

__ flabellum-Veneris. . 208

- pinnata ....... 206

- placomus....... 207

- verrucosa....... 205

Gorgoniada . . . . . . . . 204

Halecium Beanii. . . . . 121

halecinum ...... 121

repens....... 373

Flustra avicularis ..... 350

- muricatum ..... 122

Halcyonellea. . . . . . . 363

Hippothoa Cassiterides. . 295

carbacea ....... 349

chartacea....... 347

coriacea........ 353

catenularia ..... 292

divaricata ...... 293

distans ....... . 354

foliacea ....... 346

sica......... 294

History of Zoophytology 29

Hydra attenuata. ..... 190

lineata. . . . . . . 353

membranacea .... 351

Murrayana ..... 350

setacea ....... 350

truncata ...... 348 oligactis ....... 191 viridis ........ 188

— vulgaris ....... 190

Hydractinia echinata . . 104 Hydraida. . . . . . . 169 
Page

Hydrina . . . . . . . 169

Idmonea Atlantica . . . 277

lluanthos Scoticus .... 260

Laomedea dichotoma ... 158

gelatinosa ...... 161

geniculata ..... 160

obliqua ....... 162

Lepralia annulata.... . 313

ansata........ 308

assimilis ...... 305

auriculata ...... 312

Ballii ........ 323

biforis . . . . . . 315

bispinosa...... 325

ciliata . . . . . . . 323

coccinea ....... 323

fenestralis ...... 318

figularis ...... 315

Gattyæ . . . . . . 326

granifera ....... 309

Hassallii . . . . . . . 305

Hyndmanni. . . . . 306

hyalina ....... 303

immersa ....... 325

innominata ..... 322

Landsborovii. . . . . 310

Lepralia linearis...... 30 s

melolontha ..... 319

nitida ........ 318

ovalis ....... 308

Peachii ....... 315

pediostoma..... 316

pertusa ....... 312

punctata...... 313

quadridentata ... 309

reticulata. ...... 317

- semilunaris ..... 322

simplex ...... 306

spinifera . . . . . . 324

tenuis........ 304

- trispinosa ...... 324

- unicornis....... 322

- variolosa. ..... 317

ventricosa ..... 306

- verrucosa. . . . . 316

- violacea....... 325

Lucernaria auricula . . . 262

- campanulata .... 263

- cyathiformis .... 264

- fascicularis ..... 261

Lucerniada. . . . . . . . 26 261

Membranipora membran. 332 
Membranipora pilosa ... 328 Milleporina ........ 219 Mimosella gracilis .... 376 Ocellina .......... 220 Oculina prolifera ..... 220 Paludicella articulata ... 380 Pavonaria quadrangularis 202 Pedicellina Belgica. .... 376 echinata ..... 375 — gracilis ....... 375 Pedicellinc......... 375 Pennatula phosphorea .. 194 Pennatulide......... 193 Plumatella emarginata . . 380 fruticosa ...... 380 repens........ 380 Plumularia Catharina... 151 - cristata ........ 145 falcata........ 1.4

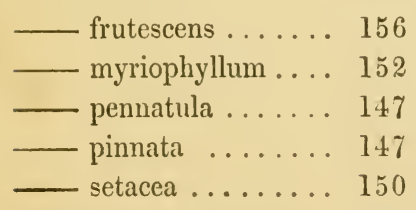

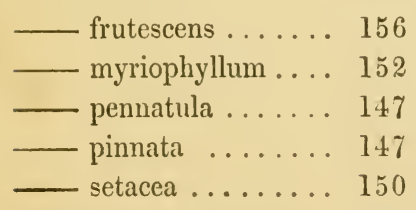

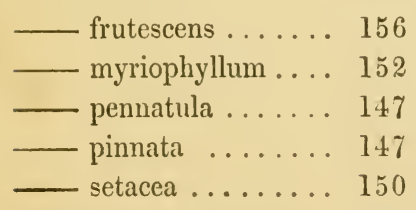

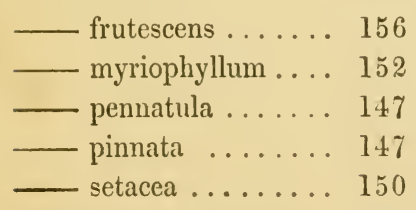

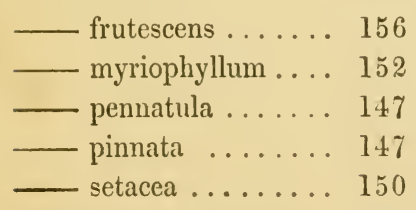

Pocillipora interstincta.. 219 PolyzOA ....... 75, 265 Polyzoa Hypocrepia 378 - Infundibulata. . $266^{\circ}$ Primnoa lepadifera..... 212 Pustulipora proboscidea 278 deflexa ....... 278 Retepora Beaniana..... 361 reticulata ..... 360 Salicornaria farciminoides 362 - sinuosa ....... 363 Sarcochitum polyoum. . 366 Sarcodictyon catenata. . 216 Scrupocellaria scrupea .. 343 Serialaria lendigera .... 367 Sertularia abietina .... 130 - argentea ...... 135 - cupressina...... 136 - Evansii ....... 126 — fallax ........ 129

_ filicula. ....... 132 fusca ......... 127 margarita ...... 128 nigra........ 126 operculata...... 133 - pinaster........ 128 - pinmata....... 127 - polyzonias....... 123 
Page Sertularia pumila ..... 125 - rosacea ....... 125

- rugosa........ 124

- tamarisca ...... 129 Sertulariada......... 120 Sertularina......... 120

Thuiaria articulata .... 139 thuia........ 139

Tubularia Dumortierii .. 117

- gracilis ........ 118

- indivisa........ 114

— $\operatorname{larynx} \ldots \ldots \ldots .117$

Tubulariada........ 107

Tubularina......... 103

Tubulipora flabellaris... 274 hispida ....... 271

— hyalina ....... 276 lobulata ....... 274
Page Tubulipora patina .... 270 - penicillata...... 273 — phalangea ....... 274 - serpens....... 275 - truncata ...... 273 Tubuliporida........ 270 Tubuliporina....... 270 Turbinolia borealis..... 222 Milletiana..... 222 Valkeria Cuscuta ..... 370 — pustulosa ...... 372 uva ......... 371 Vesicularia spinosa..... 368 Vesicularina ........ 366 Virgularia mirabilis .... 197 Zoanthina......... 224 Zoanthus Couchii...... 225 



